\title{
GUILHERME RODRIGUES LINHARES
}

Redução de acidentes rodoviários por derrapagem com emprego de Tratamento Superficial Duplo com Asfalto Modificado por Borracha 


\section{GUILHERME RODRIGUES LINHARES}

Redução de acidentes rodoviários por derrapagem com emprego de tratamento superficial duplo com asfalto modificado por borracha

\section{Versão Corrigida}

Dissertação apresentada à Escola Politécnica da Universidade de São Paulo para obtenção do título de Mestre em Ciências. 


\section{GUILHERME RODRIGUES LINHARES}

Redução de acidentes rodoviários por derrapagem com emprego de tratamento superficial duplo com asfalto modificado por borracha

Dissertação apresentada à Escola Politécnica da Universidade de São Paulo para obtenção do título de Mestre em Ciências.

Área de concentração:

Engenharia de Transportes

Orientadora: Prof. $\stackrel{\text { a }}{ }$ Titular Liedi Legi Bariani Bernucci 
Autorizo a reprodução e divulgação total ou parcial deste trabalho, por qualquer meio convencional ou eletrônico, para fins de estudo e pesquisa, desde que citada a fonte.

Este exemplar foi revisado e corrigido em relação à versão original, sob responsabilidade única do autor e com a anuência de seu orientador.

São Paulo, de de

Assinatura do autor:

Assinatura do orientador:

\section{Catalogação-na-publicação}

Linhares, Guilherme

Redução de acidentes rodoviários por derrapagem com emprego de tratamento superficial duplo com asfalto modificado por borracha / G. Linhares -- versão corr. -- São Paulo, 2021. 125

p.

Dissertação (Mestrado) - Escola Politécnica da Universidade de São Paulo. Departamento de Engenharia de Transportes.

1.pavimentação 2.acidentes de trânsito 3.tratamento superficial 4.asfalto borracha I.Universidade de São Paulo. Escola Politécnica. Departamento de Engenharia de Transportes II.t. 


\section{AGRADECIMENTOS}

Aos meus pais e à minha família, que são a base do que hoje me tornei.

Ao José Mário Cortez Chaves, meu mentor e minha inspiração profissional.

À minha orientadora, Liedi Légi Bariani Bernucci, por todos os seus conselhos, ensinamentos, e por ter me guiado por este caminho extremamente relevante que é a segurança viária.

A todos os meus colegas de trabalho que me auxiliaram ao longo desta jornada, seja na realização de ensaios em campo, seja no levantamento de dados.

À Arteris e à ANTT, que tornaram possível a realização desta pesquisa de campo, através do financiamento do projeto.

Ao meu amigo Nyelthon da Rosa Refatti, por ter me auxiliado na elaboração de algoritmos que agilizaram consideravelmente a compilação e cruzamento dos dados.

Ao Orlando Yesid Esparza Albarracin, por ter me auxiliado na realização da análise estatística dos dados.

À Fircon Engenharia e seus colaboradores, pelos ensinamentos práticos durante a construção dos segmentos experimentais.

E a todos que de alguma outra forma me ajudaram e me incentivaram ao longo desta jornada. 
Difficult roads often lead to beautiful destinations.

Zig Ziglar 


\section{RESUMO}

LINHARES, Guilherme Rodrigues. Redução de acidentes rodoviários por derrapagem com emprego de Tratamento Superficial Duplo com Asfalto Modificado por Borracha. Dissertação (Mestrado) - Escola Politécnica da Universidade de São Paulo, São Paulo, 2021.

Estima-se que os acidentes de trânsito são responsáveis pela morte de mais de 1,35 milhões de pessoas anualmente em todo o mundo. No Brasil, estes acidentes são responsáveis pela morte de mais de 40 mil pessoas todo ano. Um fator crítico para ocorrência destes acidentes é o comportamento humano, que se encontra presente em pelo menos $95 \%$ das ocorrências, isoladamente ou combinado a outros fatores. Entretanto, outro fator que merece especial atenção, uma vez que é passível de controle pelos gestores, é a condição da via. Associada às condições climáticas, ela tem participação na ocorrência de até $37 \%$ dos acidentes. Desta forma, o presente trabalho objetivou estudar a redução de acidentes pelo aumento da aderência entre pneu e pavimento empregando Tratamento Superficial Duplo com Asfalto Modificado por Borracha (TSD-AMB) em dois segmentos da rodovia Régis Bittencourt, que em condições adversas de precipitação, conjugada a curvas fechadas e declives, são críticos quanto a acidentes. Os resultados de textura obtidos por meio da utilização de um perfilômetro a laser demonstram que o TSD-AMB caracteriza-se por macrotextura aberta ou rugosa, necessária para melhorar a capacidade de drenagem superficial de água de chuva sem criar facilmente lâmina de água sobre a superfície, que pode levar a derrapagens e à hidroplanagem dos veículos, e aumento da probabilidade de acidentes. A avaliação realizada com o equipamento medidor de atrito Grip-Tester demonstrou a obtenção de valores elevados de atrito do TSD. Esta melhoria na condição de superfície do pavimento levou a uma redução considerável da ocorrência de acidentes, principalmente aqueles ocorridos em pista molhada. A utilização de soluções asfálticas com macrotextura aberta ou rugosa e aumento de atrito propicia a redução de acidentes em trechos críticos de rodovias, principalmente em situações de pista molhada. 


\begin{abstract}
LINHARES, Guilherme Rodrigues. Reduction of traffic accidents by skid resistance increase using double surface treatment with rubber modified asphalt on road pavements. Thesis (Master's degree) - Escola Politécnica da Universidade de São Paulo, São Paulo, 2021.
\end{abstract}

Traffic accidents are estimated to be responsible for the deaths of more than 1.35 million people annually worldwide. Just in Brazil, these accidents are responsible for more than 40 thousand deaths every year. Human behavior is one of the most critical factors for the occurrence of these accidents, since it is present in at least $95 \%$ of the occurrences (alone or in combination with other factors). However, roadway condition is a factor that deserves special attention, since it is controllable and accounts for up to $37 \%$ of accidents when associated with climatic conditions. Thus, the present study aimed to evaluate the application of a Double Bituminous Surface Treatment using a Crumb Rubber Modified Asphalt in terms of reducing accidents in critical stretches along Régis Bittencourt (BR116) highway. The Double Bituminous Surface Treatment exhibited a high value for macrotexture, necessary to enhance the pavements capacity to rapidly drain the water from pavement surface without creating a water film, which may lead to vehicle hydroplaning and, consequently, to an increase in probability of accidents. The pavement exhibited a high surface friction in terms of Grip Number, measured using a Grip Tester. The improvement in macrotexture and surface friction resulted in a considerable reduction of accidents, especially the ones that occur under wet conditions. The use of asphalt mixtures with open macrotexture and high surface friction result in a high pavement skid resistance, which lead to a reduction of accidents in critical stretches along the referred highway, specially under wet weather conditions. 


\section{LISTA DE FIGURAS}

Figura 1 - Taxa de envolvimento em acidentes de acordo com a variação da velocidade em relação à média de operação

Figura 2 - Consumo de álcool como causa de acidentes fatais - dados de 2002, 2003 ou 2004

Figura 3 - Risco de envolvimento em acidentes em função do teor alcoólico no sangue dos condutores

Figura 4 - Fenômeno de Retrorrefletividade em sinalizações horizontais .14

Figura 5 - Demarcações horizontais com valores conhecidos de retrorrefletividade......15 Figura 6 - Curva de distribuição de frequência acumulada de velocidades observadas

Figura 7 - (a) Força Centrípeta (observador inercial); (b) Força Centrífuga (observador interno, dentro do veículo). 19

Figura 8 - Representação da declividade transversal (Superelevação)

Figura 9 - Desenvolvimento de curvas reversas com formação da lâmina d'água em função da transição de superelevação. 28

Figura 10 - Risco de acidentes em relação ao IRI do pavimento 30

Figura 11 - Afundamento em trilha de roda com acúmulo de água. 31

Figura 12 - Exemplos de buracos no pavimento 32

Figura 13 - Ilustração representativa dos diversos tamanhos de textura para a superfície de um pavimento. .33

Figura 14 - Influência da textura superficial na caracterização da superfície dos pavimentos. .34

Figura 15 - Representação da microtextura e macrotextura superficial de pavimentos vista em corte .34

Figura 16 - Principais mecanismos do atrito entre pneu e pavimento .35

Figura 17 - (a) macrotextura aberta, condição desejável; (b) macrotextura fechada, condição indesejável; (c) microtextura rugosa, condição desejável e; (d) microtextura polida, condição indesejável.. .36

Figura 18 - Hidroplanagem Dinâmica 


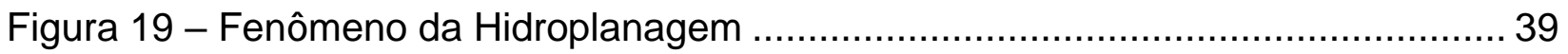

Figura 20 - Zonas de contato na ocorrência da hidroplanagem.................................. 40

Figura 21 - Representação gráfica das equações de Gallaway e Agrawall .................... 44

Figura 22 - Comparativo entre a macrotextura de diversos tipos de pavimentos .......... 47

Figura 23 - Rodovia Régis Bittencourt (BR 116) - Trecho administrado pela Autopista

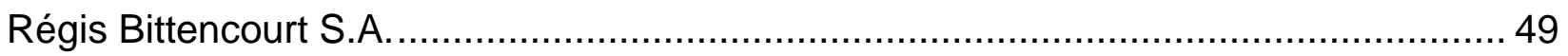

Figura 24 - Localização dos pluviógrafos instalados nas praças de pedágio da rodovia 53

Figura 25 - Avaliação da densidade de acidentes mensal, no período entre 2009 e 2016 55

Figura 26 - Dados pluviométricos mensais médios entre 2014 e 2016, para os pluviógrafos instalados nas praças de pedágio ....................................................... 55

Figura 27 - Densidade média de Acidentes Pista NORTE - 2009-2016 ....................... 56

Figura 28 - Densidade média de Acidentes Pista SUL - 2009-2016 …....................... 57

Figura 29 - Estimador de Densidade Kernel (EDK) ............................................ 58

Figura 30 - Mapa de densidade Kernel para os acidentes ocorridos na (a) Pista Norte e

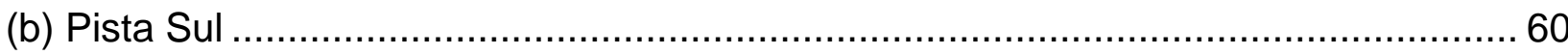

Figura 31 - Segmentos de maior densidade de acidentes - Pista Norte ........................6 60

Figura 32 - Segmentos de maior densidade de acidentes - Pista Sul .......................... 61

Figura 33 - Quantidade acumulada de acidentes entre 2009 e 2016, por causa provável,

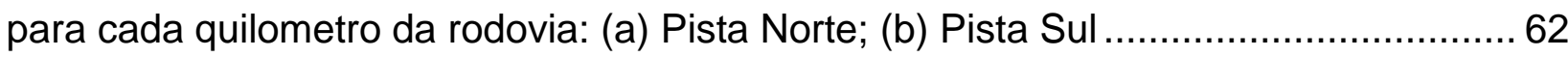
Figura 34 - Realização do levantamento topográfico para verificação das condições geométricas dos segmentos experimentais. 64

Figura 35 - (a) Parâmetros geométricos do trecho experimental 1; (b) Vista superior do trecho experimental 1 65

Figura 36 - (a) Parâmetros geométricos do trecho experimental 2; (b)Vista superior do

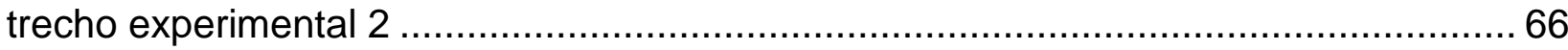

Figura 37 - Relação entre Velocidade e Fator de Atrito (AASHTO e DNIT) .................. 67

Figura 38 - Representação da camada de TSD ………........................................ 70

Figura 39 - Caixa Dosadora .............................................................................. 71 
Figura 40 - Granulometria dos agregados para aplicação na $1^{\text {a }}$ camada (Brita 1) e $2^{\mathrm{a}}$

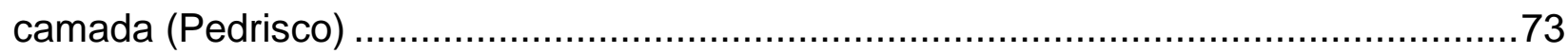

Figura 41 - Pré envolvimento realizado nos agregados (a) Brita 1 e (b) Pedrisco..........75

Figura 42 - Calibração das taxas de aplicação no canteiro de obras ............................75

Figura 43 - Sobreposição dos Sprays e altura da Barra Espargidora............................77

Figura 44 - Posicionamento do papel Kraft no início do segmento..............................78

Figura 45 - Espalhamento dos materiais da primeira camada do TSD ........................78

Figura 46 - (a) Compactação da 1aㅡ camada com utilização de rolo pneumático; (b) Textura obtida para a primeira camada (Brita 1) ..................................................... 79

Figura 47 - (a) Posicionamento do papel Kraft para início da execução da $2^{2}$ camada, (b) Resfriamento da camada através da aplicação de água, (c) Limpeza da camada finalizada, para remoção de agregados soltos, e (d) Textura final obtida ......................80

Figura 48 - Comparação entre as camadas de TSD (faixa da esquerda) e CBUQ (faixa da direita) após derramamento de água na Superfície ...............................................81 Figura 49 - Escoamento superficial da água no TSD com asfalto modificado por borracha

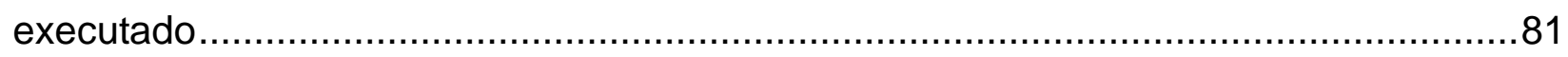

Figura 50 - (a) Representação do perfilômetro a laser; (b) Grip-Tester .........................82 Figura 51 - Trecho Experimental 1: (a) Valores de macrotextura inicial (MTD); (b) Valores de atrito inicial (GN). .83

Figura 52 - Trecho Experimental 2: (a) Valores de macrotextura inicial (MPD); (b) Valores de atrito inicial (GN)

Figura 53 - Intervalo de Confiança de 95\% para a evolução dos parâmetros de macrotextura e dos trechos experimentais e trechos adjacentes ao longo do tempo ....87 Figura 54 - Intervalo de Confiança de 95\% para a evolução dos parâmetros de atrito dos trechos experimentais e dos trechos adjacentes ao longo do tempo.....

Figura 55 - Análise da evolução da densidade média de acidentes para os períodos antes e depois: (a) Trecho Experimental 1; (b) Trecho Experimental 2 e (c) Trechos

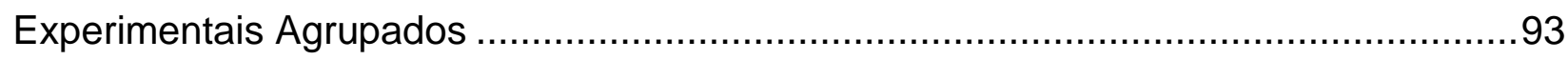

Figura 56 - Evolução da densidade mensal de acidentes - Trecho experimental 1 .......95 Figura 57 - Evolução da densidade mensal de acidentes - Trecho experimental 2 .......96 
Figura 58 - Evolução da densidade mensal de acidentes - Trechos experimentais

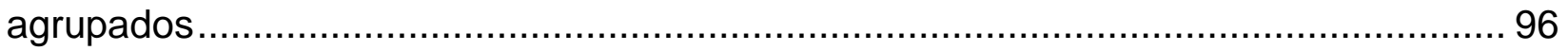

Figura 59 - Dados históricos de ocorrência de acidentes para todo o trecho em serra na pista sul, excluindo os trechos experimentais. 100

Figura 60 - Dados históricos de ocorrência de acidentes para todo o trecho em serra na pista norte 101

Figura 61 - Evolução da densidade mensal de acidentes - Segmento de referência pista sul 102

Figura 62 - Evolução da densidade mensal de acidentes - Segmento de referência pista norte. 103

Figura 63 - Avaliação da densidade média de acidentes para o segmento de 2 quilômetros após o trecho experimental 1 106

Figura 64 - Avaliação da densidade média de acidentes para o segmento de 2 quilômetros após o trecho experimental 2 107

Figura 65 - Segmento de 2 quilômetros após o trecho experimental 1 ....................... 108

Figura 66 - Segmento de 2 quilômetros após o trecho experimental 2 ......................... 109 Figura 67 - Evolução da densidade mensal de acidentes - Segmento passíveis de transferência de acidentes para o trecho experimental 1 109 Figura 68 - Evolução da densidade mensal de acidentes - Segmento passíveis de transferência de acidentes para o trecho experimental 2 110 


\section{LISTA DE TABELAS}

Tabela 1 - Custos anuais estimados de acidente de trânsito no Brasil .............................2

Tabela 2 - Fatores de contribuição para ocorrência de acidentes ...................................3

Tabela 3 - Classificação Static Rollover Thresold para CVCs ....................................13

Tabela 4 - Valores máximos admissíveis para superelevação (Informações extraídas de

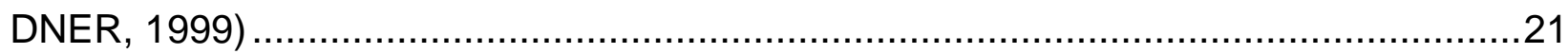

Tabela 5 - Coeficientes de atrito em função da velocidade de projeto ..........................22

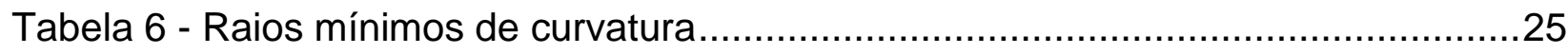

Tabela 7 - Modelo das 3 Zonas - Hidroplanagem Total e Parcial ...............................41

Tabela 8 - Risco potencial de hidroplanagem com base na velocidade dos veículos e na espessura da lâmina de água

Tabela 9 - Densidade de acidentes (acidentes/100 mil veículos. $\mathrm{km}$ ) por ano e por sentido

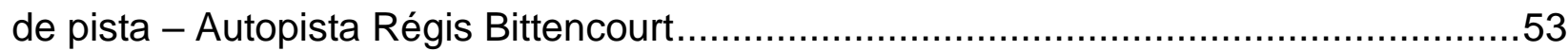

Tabela 10 - Segmentos com elevada densidade de acidentes .................................57

Tabela 11 - Velocidade Máxima Admissível nas Curvas do Trecho Experimental 1 .....68

Tabela 12 - Velocidade Máxima Admissível nas Curvas do Trecho Experimental 2......68

Tabela 13 - Análise do ligante asfáltico utilizado nos trechos experimentais ................72

Tabela 14 - Características básicas dos agregados, fundamentais para execução do TSD

Tabela 15 - Taxas de aplicação dos materiais para execução do TSD ........................74 Tabela 16 - Resultados dos ensaios de Macrotextura e Atrito logo após a aplicação do TSD-AMB .85

Tabela 17 - Frequência de realização de ensaios .86

Tabela 18 - Teste F para comparação entre variância dos dados de MTD obtidos ao longo do tempo para o trecho experimental em TSD-AMB .88

Tabela 19 - Teste T para comparação entre médias dos dados de MTD obtidos ao longo do tempo para o trecho experimental em TSD-AMB

Tabela 20 - Teste F para comparação entre variância dos dados de GN obtidos ao longo do tempo para o trecho experimental em TSD-AMB. 
Tabela 21 - Teste T para comparação entre médias dos dados de MTD obtidos ao longo do tempo para o trecho experimental em TSD-AMB .................................................. 91 Tabela 22 - Histogramas para a densidade mensal de acidentes do trecho experimental 1

Tabela 23 - Resultados do teste de Mann-Whitney para comparação entre as densidades mensais antes e depois da aplicação do TSD-AMB. ................................................ 98 Tabela 24 - Histogramas para a densidade mensal de acidentes dos trechos em serra, considerados como segmentos de referência ...................................................... 104 Tabela 25 - Resultados do teste de Mann-Whitney para comparação entre as densidades mensais dos segmentos de referência, antes e depois da data de aplicação do TSD-AMB. 105

Tabela 26 - Histogramas para a densidade mensal de acidentes dos segmentos passíveis de transferência de acidentes. 111 Tabela 27 - Resultados do teste de Mann-Whitney para comparação entre as densidades mensais dos segmentos passíveis de transferência de acidentes, antes e depois da data de aplicação do TSD-AMB 112 


\section{LISTA DE EQUAÇÕES}

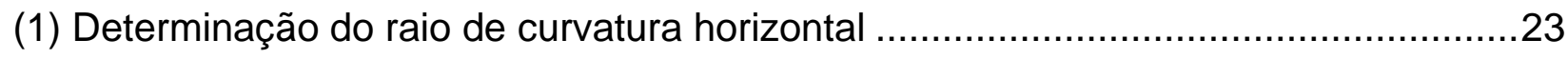

(2) Superelevação para trechos em curva com raio superior ao mínimo .......................24

(3) Valor mínimo necessário para superelevação ..................................................27

(4) Equação de Gallaway para determinação da velocidade crítica de hidroplanagem

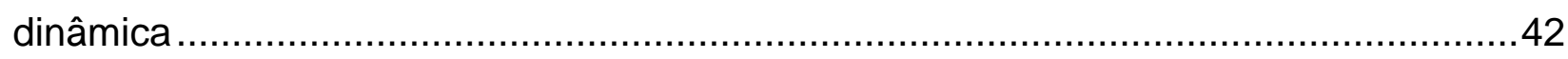

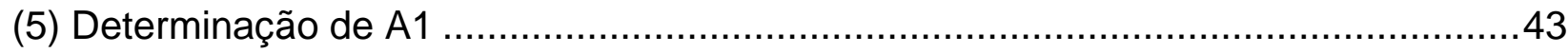

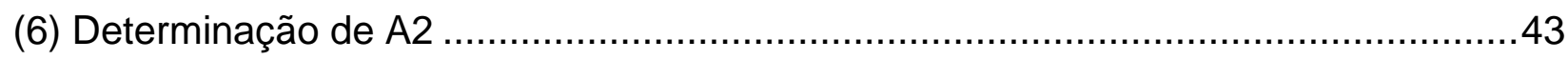

(7) Determinação da altura de água acima das asperezas do pavimento ......................43

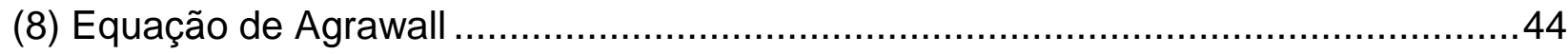

(9) Equação simplificada para determinação da velocidade crítica de ocorrência de

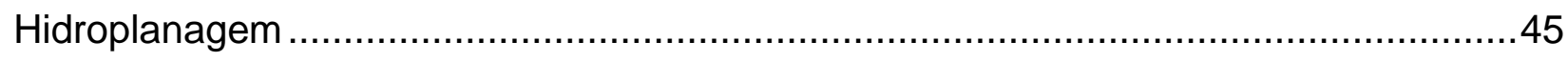
(10) Fórmula matemática utilizada para cálculo da densidade em análise estatística

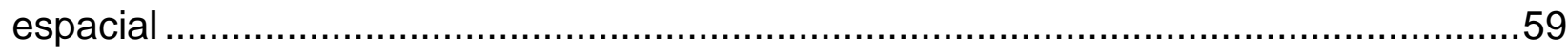




\section{SUMÁRIO}

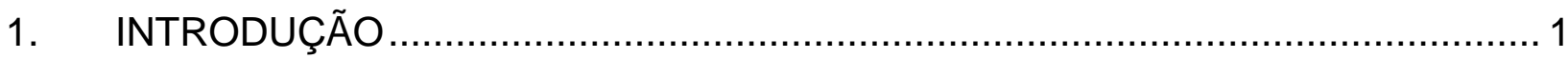

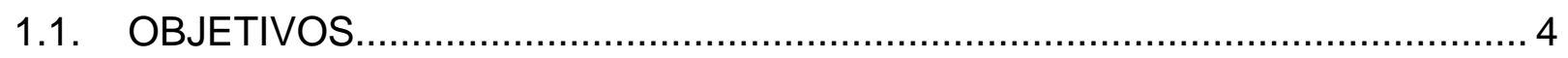

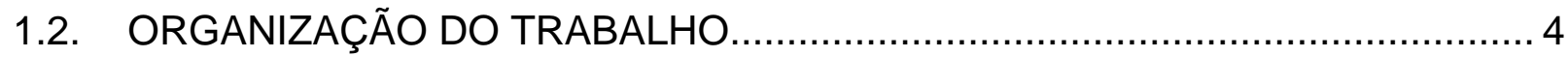

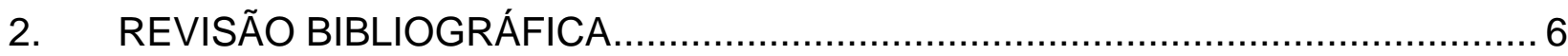

2.1. Principais fatores relacionados à ocorrência de acidentes de trânsito ................ 6

2.1.1. Fatores de risco associados ao Comportamento Humano .......................... 6

2.1.1.1. Velocidade Incompatível com a Via .................................................... 6

2.1.1.2. Consumo de álcool e substâncias entorpecentes ................................... 8

2.1.1.3. Cansaço e Distração........................................................................ 10

2.1.2. Fatores de risco associados aos veículos .............................................. 11

2.1.2.1. Manutenção dos sistemas auxiliares veiculares .................................. 11

2.1.2.2. Combinação de Veículos Rodoviários de Carga................................... 12

2.1.3. Fatores de risco associados à rodovia ................................................. 14

2.1.3.1. Sinalização Viária e Visibilidade ....................................................... 14

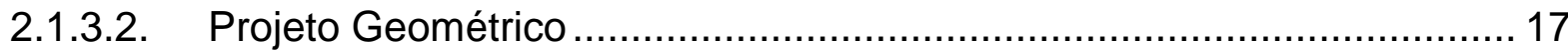

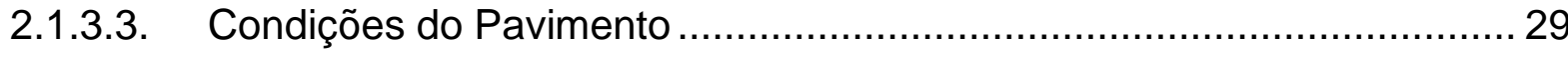

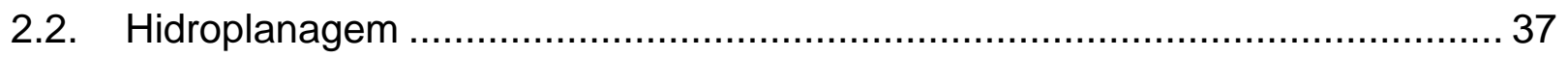

2.3. Principais soluções de pavimento para redução de acidentes ........................ 45

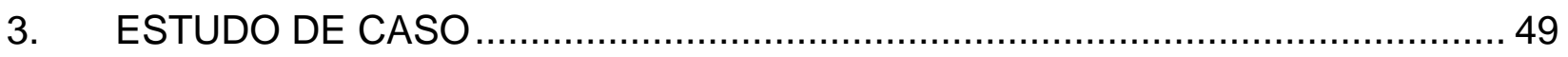

3.1. Registro histórico de ocorrência de acidentes na BR-116 (Trecho São Paulo -

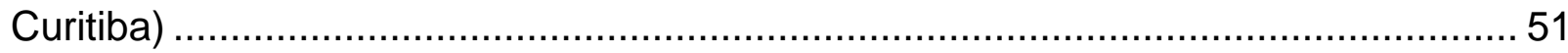

3.2. Identificação dos segmentos críticos de ocorrência de acidentes .....................56

3.3. Avaliação geométrica dos segmentos experimentais .......................................63

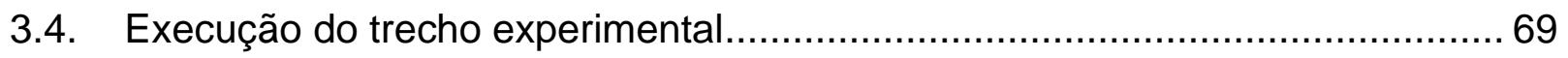




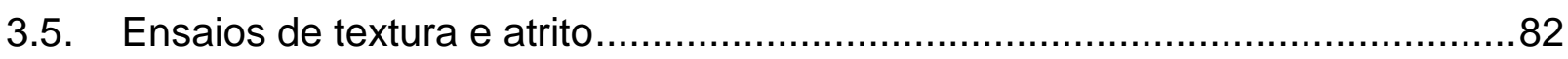

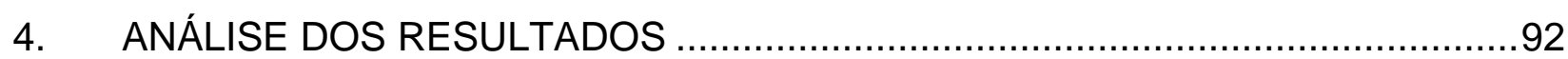

4.1. Avaliação da eficiência do TSD-AMB na redução de acidentes por derrapagem

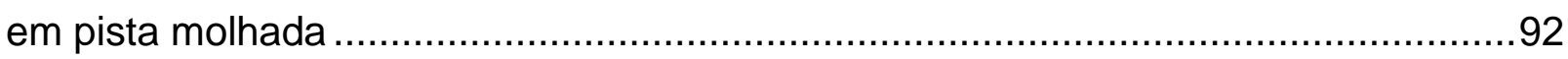

4.1.1. Comparação direta - Densidade de acidentes Antes e Após a aplicação do

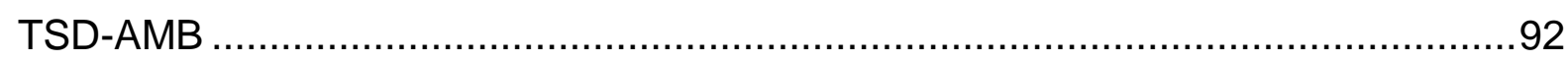

4.1.2. Comparação dos resultados com segmentos de referência .......................99

4.2. Avaliação da transferência de acidentes para segmentos posteriores............106

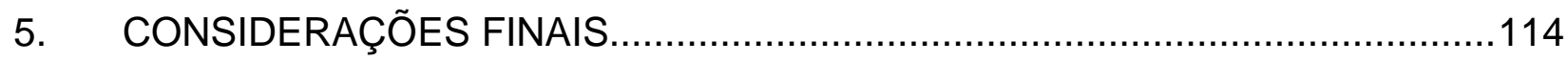

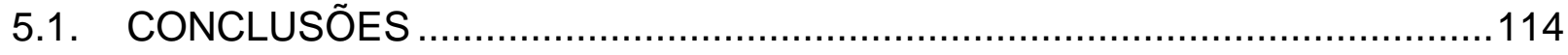

5.2. SUGESTÕES PARA ESTUDOS FUTUROS ..........................................116

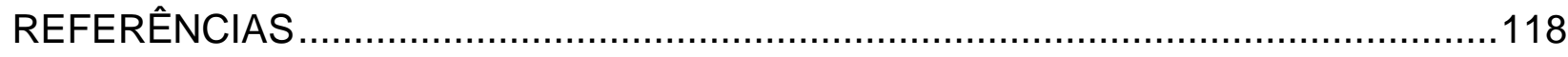





\section{INTRODUÇÃO}

Os acidentes de trânsito são responsáveis por uma quantidade alarmante de mortes em todo o mundo. Estima-se que as lesões provenientes da ocorrência destes acidentes são responsáveis pela morte de mais de 1,35 milhão de pessoas por ano em todo o mundo e lideram as estatísticas de causa de mortes para pessoas com idade entre 5 e 29 anos (WHO, 2018). Além da perda de vidas, os acidentes de trânsito também representam um grave problema econômico, tanto para as nações, quanto para as famílias das vítimas (WHO, 2015; Bucharles, 2014). No que tange ao aspecto econômico dos acidentes, pode-se citar: (i) os custos associados às pessoas, como atendimento hospitalar, perda de produção, custo previdenciário, de remoção e de translado; (ii) os custos associados aos veículos, como os danos materiais, perda de carga, remoção e reposição; (iii) os custos associados à via e ao meio-ambiente, como os danos às propriedades públicas e privadas; e (iv) os custos institucionais, como o atendimento policial e os processos judiciais; além dos (v) custos não valoráveis, como os custos operacionais e o atraso em viagens dos demais usuários das vias, e também as sequelas invisíveis, tendo como principal exemplo o estresse pós-traumático (IPEA, DENATRAN e ANTP, 2006).

De acordo com dados divulgados pelo Instituto de Pesquisa Econômica Avançada (IPEA) em 2015, no Brasil, o custo dos acidentes de trânsito ocorridos nas rodovias federais, estaduais e municipais, bem como em áreas urbanas no ano de 2014 , encontram-se aproximadamente entre $R \$ 47,5$ bilhões e $R \$ 56,3$ bilhões. Para os acidentes ocorridos apenas nas rodovias, excluindo-se as áreas urbanas, este custo para a sociedade se encontra aproximadamente entre $R \$ 37,6$ bilhões e $R \$ 43,4$ bilhões, representando em média $78 \%$ do custo total dos acidentes. A Tabela 1 apresenta a composição do custo total dos acidentes, estimado em função de sua localização. Cabe salientar que foram consideradas diferentes estimativas de custos de acordo com a metodologia utilizada, e informações mais detalhadas podem ser obtidas no relatório do IPEA (IPEA, 2015). 
Tabela 1 - Custos anuais estimados de acidente de trânsito no Brasil

\begin{tabular}{lcc}
\hline \multirow{2}{*}{$\begin{array}{c}\text { Localização dos } \\
\text { acidentes }\end{array}$} & \multicolumn{2}{c}{$\begin{array}{c}\text { Custo anual estimado (em bilhões de reais, valores com } \\
\text { base em dezembro de 2014) }\end{array}$} \\
\cline { 2 - 3 } & Estimativa Mínima & Estimativa Máxima \\
\hline Rodovias Federais & - & $\mathrm{R} \$ 12,8$ \\
\hline $\begin{array}{l}\text { Rodovias Estaduais e } \\
\text { Municipais }\end{array}$ & $\mathrm{R} \$ 24,8$ & $\mathrm{R} \$ 30,5$ \\
\hline Áreas Urbanas & $\mathrm{R} \$ 9,9$ & $\mathrm{R} \$ 12,9$ \\
\hline
\end{tabular}

Muitos dos acidentes podem estar relacionados a falhas humanas e às condições de conservação dos veículos, porém, em diversos casos, a infraestrutura tem papel que ora pode ser a responsável, ora pode não facilitar a boa condução do veículo por parte do motorista.

Estudos realizados por Sabey e Saughton (1975, apud FERRAZ 2012), Treat et al. (1979, apud FERRAZ 2012), Wierwille et al. (2002), Zein e Navin (2004), Paula (2008) e Scaringella (apud FERRAZ 2012) apontam que, apesar de o fator humano ser 0 principal facilitador para a ocorrência de acidentes de trânsito, a condição da via, associada ao meio ambiente, também possui elevada participação nestas ocorrências. A Tabela 2 apresenta um resumo das informações extraídas dos estudos acima mencionados.

Uma vez que o comportamento humano e as condições de manutenção dos veículos são fatores que não podem ser controlados integralmente pelos órgãos públicos e empresas privadas responsáveis pelo gerenciamento de sistemas viários, existe a necessidade de se buscar a implementação de ações apropriadas nas áreas passiveis de controle, visando a redução da probabilidade de ocorrência de acidentes e sua severidade (FERRAZ et al., 2012). Tendo isto em foco, a área de engenharia rodoviária vem buscando constantemente soluções para redução do problema de acidentalidade viária, sendo o grande desafio a implementação de técnicas de alta eficiência e viáveis economicamente. 
Tabela 2 - Fatores de contribuição para ocorrência de acidentes

\begin{tabular}{|c|c|c|c|c|c|}
\hline \multirow[b]{2}{*}{ Fator } & \multicolumn{3}{|c|}{ Trechos Rodoviários } & \multicolumn{2}{|c|}{ Trechos Urbanos } \\
\hline & $\begin{array}{c}\text { Valores } \\
\text { citados por } \\
\text { Sabey \& } \\
\text { Staughton } \\
(1975) \text { e } \\
\text { Treat et al. } \\
(1979)\end{array}$ & $\begin{array}{c}\text { Valores } \\
\text { citados } \\
\text { por } \\
\text { Wierwille } \\
\text { (2002) }\end{array}$ & $\begin{array}{c}\text { Valores } \\
\text { citados } \\
\text { por Zein } \\
\text { e Navin } \\
\text { (2004) }\end{array}$ & $\begin{array}{c}\text { Valores } \\
\text { obtidos no } \\
\text { Brasil por } \\
\text { Scaringella } \\
\text { s.d. }\end{array}$ & $\begin{array}{c}\text { Valores } \\
\text { citados } \\
\text { por } \\
\text { Paula } \\
(2008)\end{array}$ \\
\hline $\mathbf{H}$ & $66,5 \%$ & $65,0 \%$ & $66,5 \%$ & $44,0 \%$ & $75,9 \%$ \\
\hline $\mathbf{A}$ & $2,5 \%$ & $2,0 \%$ & $4,0 \%$ & $0,0 \%$ & $0,5 \%$ \\
\hline $\mathbf{V}$ & $3,0 \%$ & $2,0 \%$ & $3,0 \%$ & $0,0 \%$ & $0,5 \%$ \\
\hline $\mathrm{H}+\mathrm{A}$ & $23,0 \%$ & $25,0 \%$ & $22,0 \%$ & $29,0 \%$ & $15,9 \%$ \\
\hline $\mathrm{H}+\mathrm{V}$ & $4,0 \%$ & $5,0 \%$ & $2,5 \%$ & $19,0 \%$ & $5,0 \%$ \\
\hline$A+V$ & $0,0 \%$ & $0,0 \%$ & $0,0 \%$ & $0,0 \%$ & $0,5 \%$ \\
\hline $\mathrm{H}+\mathrm{A}+\mathrm{V}$ & $1,0 \%$ & $1,0 \%$ & $2,0 \%$ & $8,0 \%$ & $1,8 \%$ \\
\hline Total & $100,0 \%$ & $100,0 \%$ & $100,0 \%$ & $100,0 \%$ & $100,0 \%$ \\
\hline Presença de H & $94,5 \%$ & $96,0 \%$ & $93,0 \%$ & $100,0 \%$ & $98,6 \%$ \\
\hline Presença de A & $26,5 \%$ & $28,0 \%$ & $28,0 \%$ & $37,0 \%$ & $18,6 \%$ \\
\hline Presença de V & $8,0 \%$ & $8,0 \%$ & $7,5 \%$ & $27,0 \%$ & $7,7 \%$ \\
\hline
\end{tabular}

Fonte: Elaborada pelo autor.

Legenda: H - Humano; A - Via e Meio Ambiente e V - Veículo.

Desta forma, o presente trabalho visa estudar as possibilidades de redução de acidentes rodoviários, principalmente em pavimentos molhados, com foco em soluções de maior viabilidade técnica e econômica para aplicação em pontos críticos de ocorrência de acidentes, onde não há a possibilidade de alteração geométrica da via. Isto porque a alteração do projeto da via requer uma adequação em geral que envolve mais recursos, que são inviáveis em certas condições de relevo e contratuais. Uma outra forma de redução de acidentes se dá pela implantação de sistemas de controle de velocidade, de modo a reduzi-la, e também por sistemas de sinalização. Quando estes recursos já se encontram instalados, poucas iniciativas podem ser tomadas, dentre elas a alteração do revestimento do pavimento para aumento de aderência pneu/pavimento. Para atingir os objetivos, o trabalho realiza, inicialmente, uma pesquisa bibliográfica acerca dos fatores determinantes para ocorrência de acidentes rodoviários, onde é dada especial atenção à relação entre a superfície dos pavimentos e a ocorrência de acidentes. Será empregado 
na demonstração deste conceito e iniciativa, um estudo de caso de pesquisa em campo onde se procede a identificação de segmentos críticos de ocorrência de acidentes na rodovia Régis Bittencourt (BR-116), em trecho sinuoso e de serra, para implementação de um trecho experimental de pavimento asfáltico que busque melhorar as condições de atrito. Após sua implantação, são feitas coletas periódicas de dados relativos a acidentes e a identificação dos benefícios que a alteração de superfície de pavimentos pode levar em termos de redução de acidentes.

\subsection{OBJETIVOS}

Esta Dissertação tem por objetivo principal estudar a redução da ocorrência de acidentes rodoviários em pavimentos molhados, em trecho crítico sinuoso, pela alteração da textura superficial do pavimento de modo a aumentar a aderência pneu-pavimento. Para apoiar esta pesquisa, foram empregados resultados obtidos em trecho da BR 116, Rodovia Regis Bittencourt, em região serrana, com curvas fechadas e presença de dispositivos de sinalização e de controle de velocidade já instalados, onde foi aplicado como camada de revestimento um Tratamento Superficial Duplo, com asfalto modificado por borracha, propiciando o aumento do atrito superficial dos pneus com o pavimento, mesmo em presença de água.

\subsection{ORGANIZAÇÃO DO TRABALHO}

Esta dissertação está organizada em 5 capítulos. O primeiro capítulo, INTRODUÇÃO, realiza uma abordagem sucinta do problema a ser estudado. Este capítulo também apresenta os objetivos propostos para buscar uma solução técnica que amenize o problema, e por fim apresenta a organização do trabalho. O segundo capítulo, REVISÃO BIBLIOGRÁFICA, realiza uma breve pesquisa dos diversos aspectos que podem estar relacionados à ocorrência de acidentes de trânsito. São elucidados os aspectos relativos ao Comportamento Humano, aspectos relativos aos Veículos, e principalmente aspectos relativos à Via, como as condições geométricas, as condições 
superficiais dos pavimentos, a presença de drenagem eficiente e a presença de sinalização viária adequada, bem como de controle sistemático de velocidade. Ainda no segundo capítulo, são apresentadas as principais técnicas utilizadas para melhoria do atrito entre pneu e pavimento. O terceiro capítulo do trabalho, ESTUDO DE CASO, apresenta o registro histórico de ocorrência de acidentes na rodovia Régis Bittencourt, bem como a metodologia de análise estatística empregada para identificação e delimitação dos trechos críticos da rodovia, bem como a camada asfáltica escolhida para melhoria das condições de atrito do pavimento. Também ilustra o procedimento executivo da aplicação desta camada asfáltica nos trechos críticos identificados e os resultados de melhoria de atrito obtidos após a restauração do pavimento. O quarto capítulo apresenta a ANÁLISE DOS RESULTADOS, que é realizada para verificação da eficiência desta camada asfáltica no que diz respeito à redução da densidade de acidentes em determinado período. Após a realização de toda análise dos resultados, este capítulo ainda especifica quais são as limitações da solução executada. O quinto e último capítulo apresenta as CONSIDERAÇÕES FINAIS e CONCLUSÕES, bem como recomendações para estudos futuros. 


\section{REVISÃO BIBLIOGRÁFICA}

\subsection{Principais fatores relacionados à ocorrência de acidentes de trânsito}

O trânsito pode ser considerado como um sistema dinâmico, constituído de alguns elementos fundamentais: o ser humano, o veículo, a via e o meio ambiente. Para que o sistema funcione em perfeita harmonia, é necessário que estes elementos interajam de maneira apropriada entre si, e quando esta interação não ocorre de maneira adequada, em virtude da falha de ao menos um fator relacionado a estes elementos, a probabilidade de ocorrência de um acidente de trânsito se torna alta (FERRAZ et al., 2012).

Nos itens a seguir, são apresentados e discutidos os principais fatores de risco associados à ocorrência de acidentes rodoviários.

\subsubsection{Fatores de risco associados ao Comportamento Humano}

\subsubsection{Velocidade Incompatível com a Via}

A velocidade de deslocamento dos veículos em uma via depende, além da capacidade dos motoristas e dos veículos, de quatro condições gerais: (i) as características físicas da via bem como a quantidade de interferências laterais, (ii) as condições climáticas, (iii) a presença de outros veículos, e (iv) as limitações de velocidade (estabelecidas por lei ou por dispositivos de controle de tráfego) (AASHTO, 2018). Desta forma, pode-se definir como velocidade incompatível aquela excessivamente alta, ou excessivamente baixa, de acordo com as condições de trafegabilidade da via.

Ferraz et al. (2012) citam que são três os principais problemas associados à utilização de velocidade incompatível, a saber: (i) a utilização de altas velocidades facilita a perda de controle do veículo quando o usuário se depara com alguma anormalidade, como próprios defeitos no veículo, presença de defeitos na pista, distração, etc., facilitando a ocorrência de acidentes; (ii) a utilização de velocidades apropriadas permite 
que os condutores tenham o tempo adequado de reação para frenagem ou desvio de trajetória quando se deparam com algum obstáculo à sua frente (outro veículo, pedestres, buracos na pista, etc.); e (iii) a grande maioria dos usuários da via esperam que todos os veículos se desloquem na velocidade adequada para o segmento, e tomam suas decisões (como por exemplo entrar na via, atravessar a via, realizar ultrapassagens e até escolher sua velocidade de deslocamento) baseados na velocidade esperada aos demais veículos. Desta forma, veículos que trafegam em velocidades muito baixas ou altas, por não corresponderem à expectativa dos demais usuários, facilitam a ocorrência de acidentes.

A Figura 1 ilustra a alteração do risco de envolvimento em acidentes de acordo com a variação da velocidade adotada em relação à velocidade média de deslocamento da via.

Figura 1 - Taxa de envolvimento em acidentes de acordo com a variação da velocidade em relação à média de operação

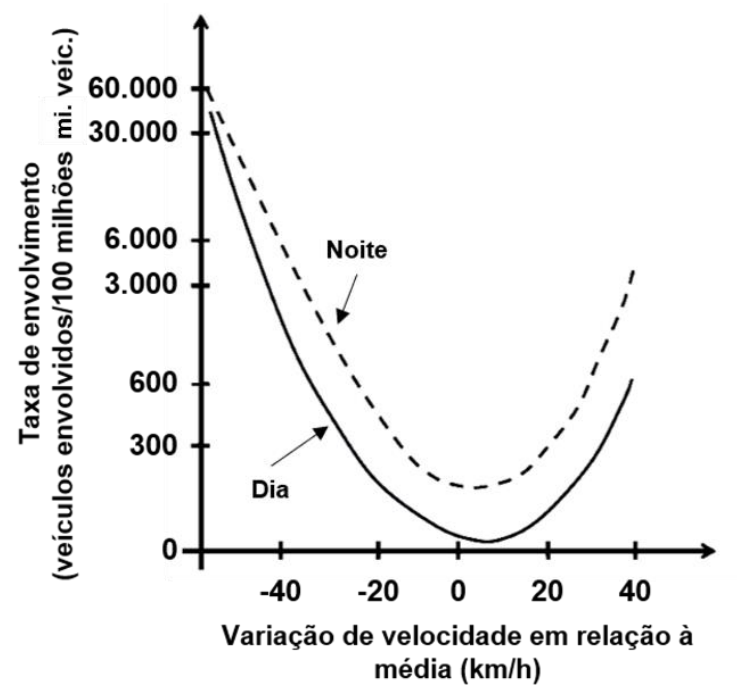

Fonte: Adaptado de AASHTO (2010)

A condução dos veículos em alta velocidade pode se tornar ainda mais crítica quando combinada com a ocorrência de chuvas, devido ao fenômeno de Hidroplanagem, que será discutido adiante. 


\subsubsection{Consumo de álcool e substâncias entorpecentes}

O risco de ocorrência de acidentes de trânsito é aumentado consideravelmente quando existe o consumo de álcool e outras substâncias entorpecentes pelos condutores dos veículos (MORLAND et al., 2011). Isto ocorre, pois estas substâncias produzem alterações fisiológicas que modificam a capacidade de discernimento, tornam os reflexos mais lentos, diminuem a vigilância e reduzem a acuidade visual (WHO, 2007). Além do risco direto de acidente, acredita-se que o álcool prejudique outros aspectos da segurança do condutor, como deixar de usar o cinto de segurança, capacete e o respeito aos limites de velocidade (WHO, 2007).

A Figura 2 mostra um panorama da influência do álcool em acidentes de trânsito com vítimas fatais em diversos países. (WHO, 2007).

Figura 2 - Consumo de álcool como causa de acidentes fatais - dados de 2002, 2003 ou 2004.

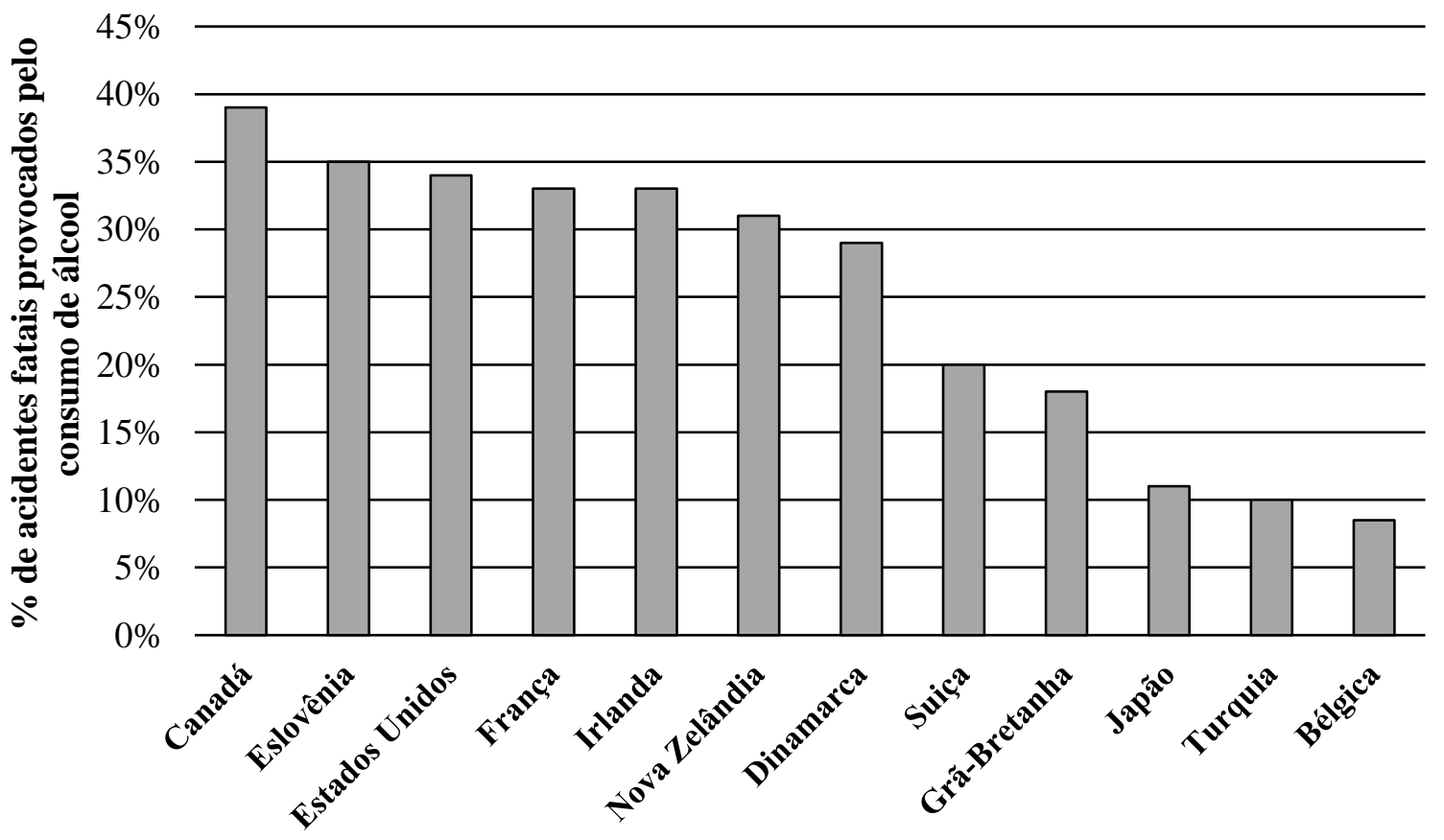

Fonte: (adaptado de WHO, 2007) 
Diversos estudos foram realizados visando relacionar a quantidade de álcool ingerida pelos condutores com o risco de envolvimento em acidentes de trânsito (BORKENSTEIN et al. 1964 APUD MAYHEW \& SIMPSON, 1983; BLOMBERG et al., 2005; PECK et al., 2008; BOGSTRAND et al., 2012, KUYPERS et al., 2012; BERNING, COMPTON \& WOCHINGER, 2015). Estes estudos fornecem evidências de que mesmo níveis moderados de álcool no sangue estão associados ao aumento do risco de acidentes.

A Figura 3 ilustra o risco de envolvimento em acidentes de trânsito em função da concentração de álcool no sangue dos condutores para os principais estudos aqui mencionados.

Figura 3 - Risco de envolvimento em acidentes em função do teor alcoólico no sangue dos condutores

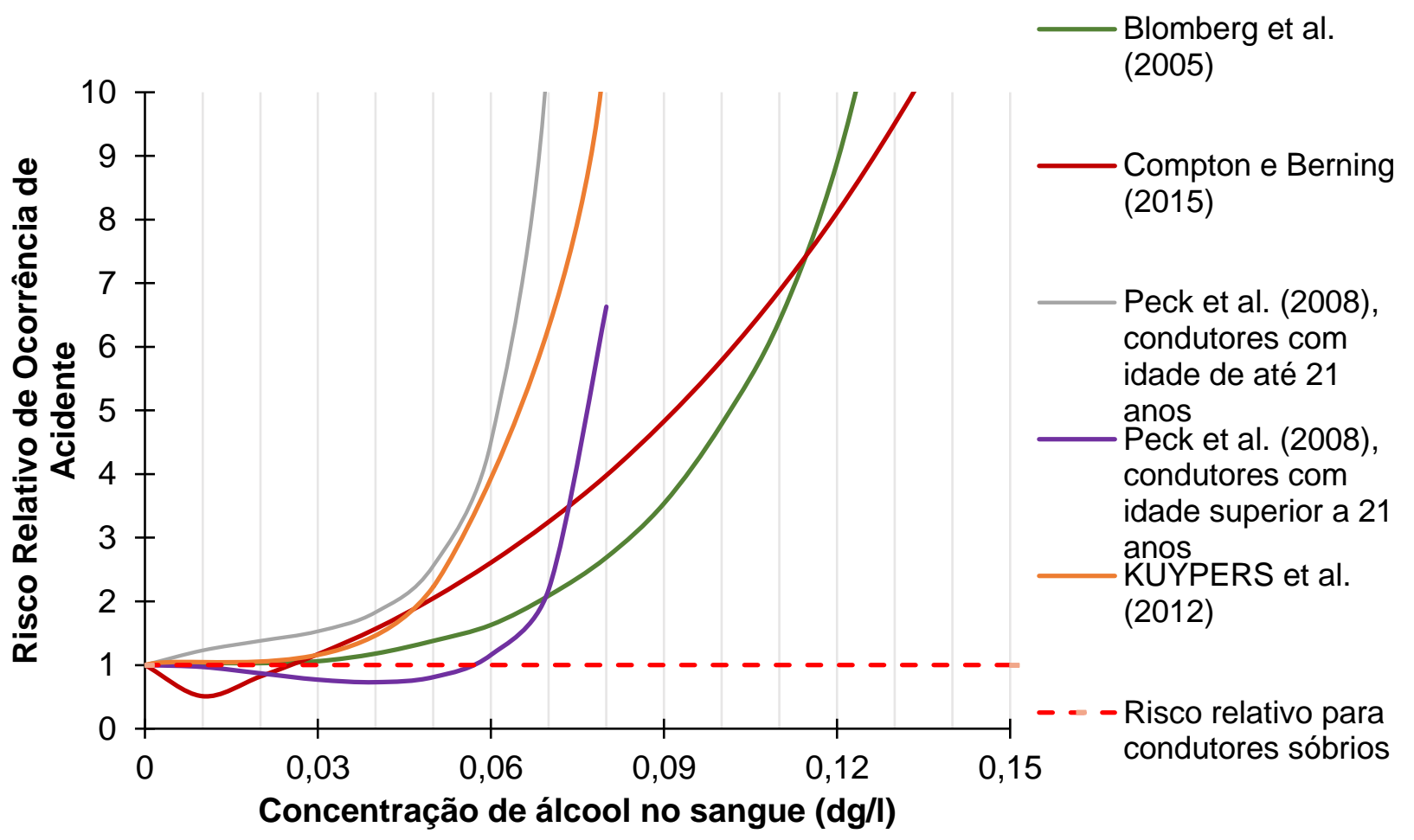

Fonte: Elaborada pelo Autor

Conforme é possível observar na Figura 3, apesar da variabilidade entre os estudos, existe um acréscimo considerável de risco de acidente para pessoas que ingerem álcool anteriormente à condução de veículos. Este acréscimo de risco é 
justificável na medida em que condutores de veículos com sua capacidade psicomotora alterada são mais propensos a desobedecer às leis de trânsito e causarem acidentes.

Bogstrand et al. (2012), Kuypers et al. (2012), Li, Brady e Chen (2013) e Compton e Berning (2015) também avaliaram como o consumo de outras substâncias entorpecentes afetam o risco de ocorrência de acidentes. Os estudos mostram que um consumo de THC (principal princípio ativo da maconha) superior a $2 \mathrm{ng} / \mathrm{ml}$ de sangue pode aumentar o risco em até 4 vezes. Estima-se que o risco de envolvimento em acidentes de trânsito quando há o consumo combinado de álcool com qualquer outra substância entorpecente pode ser 231,9 vezes superior se comparado ao risco para pessoas sóbrias

Pode-se concluir que os motoristas que fazem uso de substâncias entorpecentes antes de dirigir, além de constituírem um risco significativo para si próprios, constituem um elevado risco para os outros usuários dos sistemas viários.

Por este motivo, dirigir veículos sob a influência de álcool ou de qualquer substância psicoativa que determine dependência, constitui infração de trânsito gravíssima, de acordo com o artigo 165 da lei № 9.503, que institui o Código de Trânsito Brasileiro (CTB). Ainda de acordo com a lei № 9.503, artigo 306, se for constatada concentração igual ou superior a 6 decigramas de álcool por litro de sangue, ou concentração igual ou superior a 0,3 miligrama de álcool por litro alveolar, a infração descrita anteriormente passa a ser considerada um crime de trânsito, podendo o condutor do veículo ser detido por até 3 anos, além de receber multa e suspensão ou proibição do direito de dirigir.

\subsubsection{Cansaço e Distração}

Dentre os fatores de risco associados ao ser humano, a condução de veículos por motoristas cansados e/ou distraídos também possui grande participação na ocorrência dos acidentes.

Conforme mencionado por Dawson et al. (2018), estima-se que o cansaço contribua para a ocorrência de $5 \%$ a $50 \%$ dos acidentes de trânsito nos países 
desenvolvidos, com valores médios entre $15 \%$ a $25 \%$. Os autores afirmam que há uma grande variabilidade nas estimativas dos diversos estudos pois não existe uma forma direta de se medir o cansaço dos motoristas envolvidos nos acidentes, como pode ser feito em relação ao consumo de álcool e outras substâncias entorpecentes.

Moradi, Nazari e Rahmani (2018), após a realização de uma meta-análise contendo 14 estudos publicados entre 1999 e 2016, chegaram à conclusão de que a condução sonolenta de veículos pode aumentar o risco de ocorrência de acidentes em até $34 \%$, se comparado aos veículos conduzidos por motoristas sem sonolência.

Segundo Trivedi et al. (2017), a execução de tarefas secundárias, como comer, conversar com outros passageiros, ou utilizar telefone celular dirigindo, são as principais formas de distração que podem facilitar a ocorrência de acidentes. De acordo com dados publicados pela National Highway Traffic Safety Administration (NHTSA) em 2017, os acidentes causados por distração foram responsáveis por $9,2 \%$ de todas as fatalidades de trânsito nos Estados Unidos para o ano de 2016.

Neste sentido, destaca-se também que os motoristas, ao dirigirem por um longo período, sempre se atentando às condições de trafegabilidade da via, acabam por apresentar um cansaço mental, o que pode favorecer distrações e facilitar a ocorrência de acidentes.

\subsubsection{Fatores de risco associados aos veículos}

\subsubsection{Manutenção dos sistemas auxiliares veiculares}

Um dos principais fatores de risco associados aos veículos é a sua condição de conservação, em especial dos sistemas auxiliares veiculares, que são aqueles responsáveis pela segurança dos veículos. Têm-se como principais exemplos o sistema de freios, o sistema de suspensão e os pneus, que são fundamentais para garantia do funcionamento dos sistemas descritos anteriormente. 
Estes dispositivos são essenciais para garantir a dirigibilidade do veículo em condições normais e adversas de tráfego e clima. O sistema de suspensão é fundamental para manutenção do contato entre as rodas e a superfície da pista, pois atua absorvendo as vibrações e impactos sofridos pelas rodas, possibilitando o controle direcional em superfícies irregulares e auxiliando significativamente na estabilidade do veículo. Já o sistema de freios tem por principal função realizar a redução da velocidade dos veículos, sendo sua eficiência extremamente importante em situações emergenciais, em que se necessita de uma rápida diminuição de velocidade para realização de manobras evasivas para evitar a ocorrência de acidentes.

Por fim, a condição de conservação dos pneus é fundamental para permitir que os sistemas de suspensão e freios atuem de maneira adequada, pois é através do atrito ocorrido com a superfície da pista que se é possível realizar o controle direcional e reduções bruscas de velocidade, sem que o veículo derrape, o que facilitaria a perda de seu controle pelo motorista. Muitas vezes, por desconhecimento da importância destes dispositivos na direção defensiva, ou até mesmo devido às limitações orçamentarias de muitos motoristas, estes sistemas são levados ao seu limite de utilização, podendo falhar em situações emergenciais, não auxiliando em evitar a ocorrência dos acidentes.

\subsubsection{Combinação de Veículos Rodoviários de Carga}

Combinações de Veículos Rodoviários de Carga (CVCs) são composições formadas por duas ou mais unidades veiculares articuladas entre si, nas quais uma das unidades é a unidade motora, e as demais unidades são responsáveis pelo acondicionamento de carga (VIEIRA, 2010). O comportamento na dinâmica lateral deste tipo de veículos é mais complexo do que a dinâmica lateral de veículos simples, pois estes podem apresentar certas instabilidades dinâmicas com o aumento de peso da carga transportada, além da posição do centro de gravidade da carga transportada (VIEIRA,2010).

Melo (2004) cita que, dentre os principais fatores críticos dos CVCs, destaca-se como o mais relevante para ocorrência de acidentes o fenômeno de amplificação traseira, 
caracterizado pelo aumento do deslocamento lateral da última unidade do conjunto durante manobras em curvas ou manobras evasivas, quando comparado ao deslocamento lateral da primeira unidade, o que pode levar ao tombamento prematuro da unidade traseira, ocasionando o tombamento de todo o conjunto.

Segundo Muller et al. (1999), os veículos de carga podem ser classificados de acordo com seu Limiar de Tombamento Lateral Estático, descrito no meio técnico como SRT (Static Rollover Thresold). Este índice expressa a aceleração máxima lateral, em g's, antes de ocorrer o tombamento lateral do veículo. A Tabela 3 apresenta a classificação proposta por Mueller et al. (1999):

\begin{tabular}{|c|c|}
\hline Classificação & SRT \\
\hline Bom & Acima de $0,35 \mathrm{~g}$ 's \\
\hline Marginal & Entre 0,30 e 0,35 g's \\
\hline Pobre & Abaixo de $0,30 \mathrm{~g}$ 's \\
\hline
\end{tabular}

Fonte: Mueller et al. (1999)

Melo (2004) cita ainda que veículos com SRT abaixo de 0,3 g's têm risco 3 vezes superior de se envolver em acidentes por tombamento, se comparado aos demais veículos.

O grande risco para estes veículos combinados de carga, com baixo SRT, reside no fato de que o motorista, que está isolado das unidades traseiras, não percebe que a última unidade está se aproximando do limiar de tombamento a tempo de evitar o acidente (MELO, 2004). Adicionalmente, cabe salientar ainda que, no Brasil, não há uma rigidez de limitação de utilização de CVCs em função do padrão geométrico da via, o que contribui para o aumento do risco de ocorrência de acidentes com este tipo de veículos. 


\subsubsection{Fatores de risco associados à rodovia}

\subsubsection{Sinalização Viária e Visibilidade}

A sinalização viária, seja ela horizontal ou vertical, possui como principal função orientar os motoristas quanto à adequada forma de utilização das vias, garantindo assim sua segurança. Para que ela cumpra este objetivo, é necessário que, além de transmitir mensagens claras e objetivas, seja vista a uma distância adequada para interpretação e tomada de decisão.

Em ambientes escuros, para que a sinalização seja perfeitamente visível, os elementos que a compõe devem ser capazes de retornar a luz originária dos faróis dos veículos para o campo de visão do motorista (Figura 4), sendo este fenômeno definido como retrorrefletividade (SALLES et al., 2015).

Figura 4 - Fenômeno de Retrorrefletividade em sinalizações horizontais

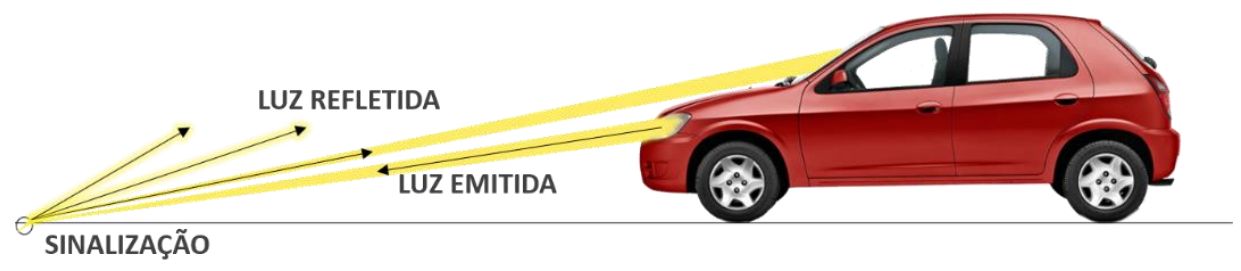

Elaborada pelo Autor.

Tal fenômeno pode ser mensurável, e de acordo com a norma técnica ASTM E1710 (2018), a unidade de medida da retrorrefletividade da sinalização viária é definida como Coeficiente de Luminância Retrorrefletida $(R L)$, que é a razão entre a luminância da superfície do pavimento e a iluminância da fonte de luz incidente, sendo os valores expressos em $\mathrm{mcd} / \mathrm{lux} / \mathrm{m}^{2}$ (milicandela por lux por metro quadrado).

A Figura 5 mostra um exemplo de demarcações horizontais com valores de retrorrefletividade conhecidos. Estas demarcações estão a 30 metros de distância do observador, de forma a simular a geometria padrão utilizada para realização das 
medições de acordo com a norma ASTM E1710 (2018). No Brasil, a avaliação de retrorrefletividade é realizada com geometria padrão de 15 metros, de acordo com a norma técnica ABNT NBR 14723 (2013).

Figura 5 - Demarcações horizontais com valores conhecidos de retrorrefletividade

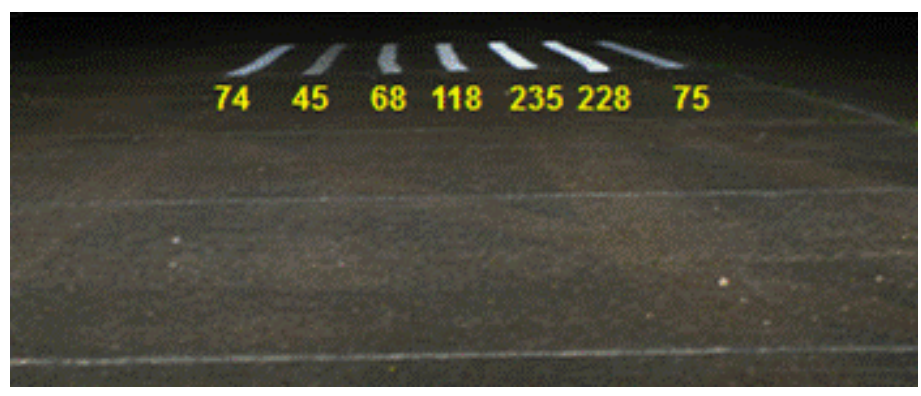

Fonte: FHWA (2019)

Estudo realizado por Smadi et al. (2008) avaliou de que forma a percepção e a retrorrefletividade da sinalização horizontal se relaciona com a ocorrência de acidentes. Os autores chegaram à conclusão de que a probabilidade de ocorrência de acidentes não se altera quando a sinalização horizontal se apresenta em boas condições, com valores de retrorrefletividade superiores a $200 \mathrm{mcd} / \mathrm{lux} / \mathrm{m}^{2}$. Entretanto, considerando apenas demarcações com valores inferiores a $200 \mathrm{mcd} / \mathrm{lux} / \mathrm{m}^{2}$, ou seja, demarcações com baixos valores de retrorrefletividade, foi encontrada uma correlação negativa, com significância estatística, entre o decréscimo dos valores de retrorrefletividade e o aumento na taxa de ocorrência de acidentes. Considerando rodovias com controle total de acesso (freeways), a redução dos valores de retrorrefletividade de $200 \mathrm{mcd} / \mathrm{lux} / \mathrm{m}^{2}$ para $50 \mathrm{mcd} / \mathrm{lux} / \mathrm{m}^{2}$ representou um aumento na probabilidade de ocorrência de acidentes em $35 \%$. Para rodovias com duas faixas de tráfego por sentido, uma redução similar nos valores de retrorrefletividade resultou em um incremento na probabilidade de ocorrência de acidentes de $37 \%$.

Estudo publicado pela CNT em 2017, relacionou os dados sobre as características da infraestrutura viária apresentados na Pesquisa CNT de Rodovias 2017 (CNT, 2017) com a base de dados de ocorrência de acidentes da Polícia Rodoviária Federal (PRF), 
para as rodovias federais. Foi possível inferir que, para condições em que o pavimento possui ótima qualidade, a gravidade dos acidentes aumenta gradativamente com a piora das condições de sinalização da via. O estudo conclui também que, independentemente das condições do pavimento, o grau de severidade dos acidentes nos trechos com condição de sinalização considerada como péssima é 2 vezes superior aos trechos em que a sinalização é considerada como ótima.

A visibilidade das demarcações viárias, bem como a visibilidade de outros veículos e também de pedestres, são fundamentais para garantia da segurança viária, tendo em vista que os veículos desenvolvem altas velocidades de deslocamento em trechos de rodovias, e qualquer alteração de traçado, a existência de pedestres, ou alterações repentinas de velocidade dos outros veículos, precisam ser vistas a uma distância suficiente para interpretação, tomada de decisão e realização de alguma manobra evasiva quando for o caso. Se os condutores dos veículos não conseguirem visualizar o risco a uma distância suficiente, a probabilidade de se envolver em um acidente se torna alta.

Diversos são os fatores que podem reduzir consideravelmente a visibilidade, merecendo especial atenção a ocorrência de neblinas, e o fenômeno de Splash e Spray.

A ocorrência de neblinas se trata de um fator ambiental que não é passível de controle pelos gestores, sendo que, para redução de acidentes nesta condição, geralmente é realizada a implantação de sinalização vertical de advertência com alertas luminosos nos trechos de maior incidência de neblina, de forma a advertir os usuários da rodovia sobre o risco, buscando uma redução de velocidade para garantir maior tempo disponível para realização de manobras evasivas quando necessário.

Em relação ao fenômeno de Splash e Spray, este advém da ocorrência de chuvas. O Splash ocorre devido à queda de grandes gotas de água na superfície do pavimento, e o Spray pode ser entendido como a suspensão de gotículas muito pequenas no ar, que formam uma névoa antes de retornar ao solo. O Splash não afeta significativamente a visibilidade dos motoristas em relação aos pedestres e outros veículos, tendo em vista que as gotas permanecem muito próximas ao solo. Entretanto, pode afetar consideravelmente a percepção da sinalização horizontal, o que se torna crítico 
principalmente em períodos noturnos. Já o Spray geralmente permanece em suspensão no ar por um período mais longo, gerando problemas mais acentuados de visibilidade, podendo confundir e desorientar os motoristas, facilitando a ocorrência de acidentes (NHTSA, 1998).

\subsubsection{Projeto Geométrico}

O projeto geométrico de uma via está diretamente relacionado à segurança viária, uma vez que altas taxas de acidentes são geralmente observadas em locais geometricamente deficientes (HASSAN; EASA; HALIM, 1997).

Ferraz et al. (2012) elencam os principais problemas geométricos que podem facilitar a ocorrência de acidentes, sendo eles: (i) existência de curva de pequeno raio após extensos trechos em tangente (ou com curvas bastante suaves); (ii) trechos com distância de visibilidade de frenagem ou ultrapassagem incompatível com a velocidade de utilização da via; deficiências na superlargura e/ou superelevação de curvas; e (iii) traçado incompreensível, que dificulte a interpretação por parte dos usuários.

Sendo assim, todos os elementos da via devem ser projetados de maneira conjunta para atendimento aos parâmetros de projeto, como a garantia da distância mínima de visibilidade, da estabilidade dos veículos, do conforto dos motoristas, bem como da drenagem e da consistência do traçado (HASSAN; EASA; HALIM, 1997).

A velocidade é um dos principais elementos que deve ser considerado para elaboração do projeto geométrico, visto que tem participação na determinação de quase todas as características técnicas da rodovia, tais como: curvatura, superelevação e distância de visibilidade, das quais depende a operação segura e confortável dos veículos (DNER, 1999). Conceitua-se como velocidade diretriz aquela selecionada para fins de projeto da via, podendo ser entendida como a maior velocidade com que pode ser percorrido um trecho viário com segurança e em condições aceitáveis de conforto, mesmo considerando o pavimento molhado (DNER,1999). A velocidade de projeto deve ser coerente com a velocidade operacional estimada de ocorrer ao longo da via. A velocidade operacional é definida como aquela em que os condutores trafegam pela via 
em condições de fluxo livre, representada frequentemente pelo $85^{\circ}$ percentil da distribuição de velocidades praticadas, podendo ser obtida através da curva de frequências acumuladas, conforme ilustrado na Figura 6.

Figura 6 - Curva de distribuição de frequência acumulada de velocidades observadas

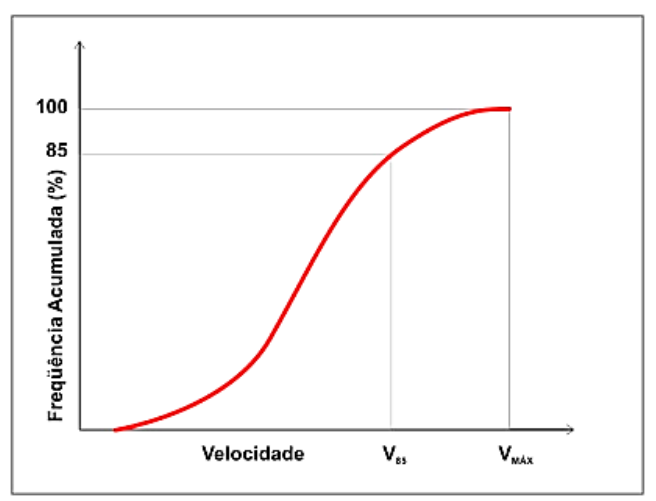

Fonte: DER-SP (2006).

Quando um veículo, com velocidade constante (V), passa de um trecho em tangente para um trecho em curva, ele sofre uma aceleração centrípeta $(F c p)$ que atua na direção interna à curvatura. Esta aceleração é sustentada pela componente de peso do veículo $(\mathrm{P})$, pela força normal $(\mathrm{N})$ e pela força de atrito lateral (Fat) existente entre os pneus dos veículos e a superfície do pavimento, ou por uma combinação destes elementos (Figura 7a). A atuação desta aceleração também pode ser entendida como equivalente à força centrífuga, que faz com que os ocupantes dos veículos sintam como se estivessem sendo arremessados para fora dos mesmos (Figura 7) (AASHTO, 2018; ARAKAWA, 2013). 
Figura 7 - (a) Força Centrípeta (observador inercial); (b) Força Centrífuga (observador interno, dentro do veículo)

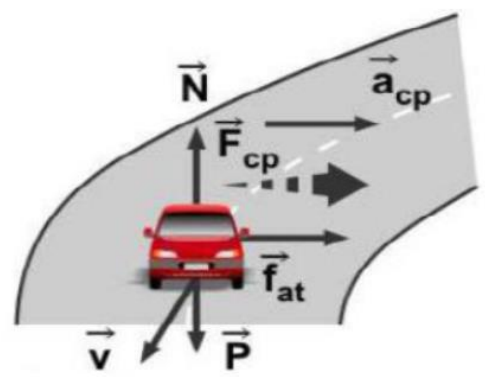

(a)

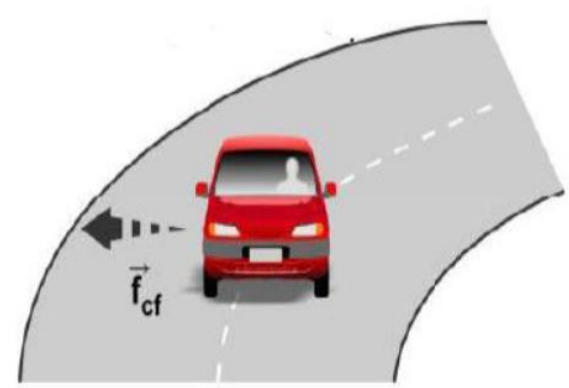

(b)

Fonte: Kabbach F. I., Notas de Aula da disciplina PTR-5725 (2017).

Com o objetivo de contrabalancear a atuação da força centrífuga sentida pelos ocupantes dos veículos, reduzindo o desconforto, garantindo a estabilidade dos veículos com a manutenção de sua velocidade e aumentando consequentemente a segurança, faz-se necessário o emprego da superelevação em trechos de curvas. A superelevação pode ser definida como uma declividade transversal ( $\alpha$ ), com caimento orientado para o lado interno (centro) da curva (DNER, 1999), conforme ilustrado na Figura 8.

A superelevação provoca o equilíbrio das forças atuantes, reduzindo a possibilidade de derrapagem dos veículos (ARAKAWA, 2013), e deve ser função da velocidade diretriz, do raio de curvatura horizontal, bem como da força de atrito lateral.

Figura 8 - Representação da declividade transversal (Superelevação)

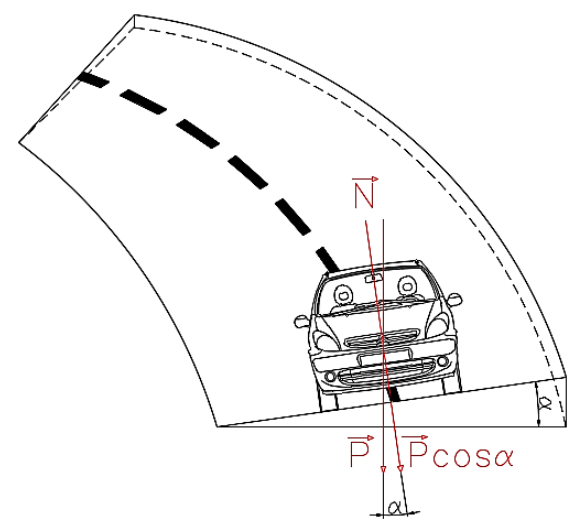

Elaborada pelo Autor 
Entretanto, existem restrições para os valores máximos de superelevação que podem ser adotados em trechos de curva, sendo estas limitações condicionadas pelos seguintes fatores (DNER, 1999; ARAKAWA, 2013; AASHTO, 2018):

(i) Condições climáticas - valores elevados de superelevação em regiões com possibilidade de deposição de neve/gelo na superfície do pavimento são inapropriados, pois, devido à consequente redução do atrito entre pneus e pavimento, veículos lentos podem deslizar com facilidade para o ponto interno da curva;

(ii) Condições topográficas - vias executadas em terrenos planos, ondulados ou montanhosos, permitem o desenvolvimento de diferentes velocidades ao longo de sua extensão, demandando diferentes taxas de superelevação em curvas;

(iii) Construtibilidade - a possibilidade de execução de vias com valores elevados de superelevação será dependente da disponibilidade de equipamentos e técnicas construtivas, que também se torna um fator de grande importância para determinação das taxas máximas de superelevação;

(iv) Necessidade de acessibilidade em faixas adjacentes - muitas vezes, quando a via se insere em áreas populosas, com intensa ocupação lateral e proximidade do passeio, existem limitações consideráveis dos valores de superelevação que podem ser empregados;

(v) Frequência de utilização da via por veículos que trafegam abaixo da velocidade diretriz - alguns veículos possuem centros de gravidade altos, e quando trafegam lentamente em trechos com alta superelevação, o seu peso é transferido quase totalmente aos pneus internos, podendo, em casos extremos, ocasionar tombamentos laterais;

(vi) Restrições de espaço para transição da superelevação - trata-se de uma limitação comum nos casos de curvas reversas e pistas com muitas faixas de rolamento;

(vii) Restrições econômicas. 
A Tabela 4 apresenta as taxas máximas de superelevação a depender das condicionantes acima mencionadas.

Tabela 4 - Valores máximos admissíveis para superelevação (Informações extraídas de DNER, 1999)

\section{Superelevação \\ Máxima (emáx) \\ Condicionantes}

Valor não usual. Deve ser utilizado apenas em casos muito específicos, onde há necessidade de melhoria de situações

$12 \%$ perigosas existentes sem possibilidade de alteração dos raios de curvatura. Esta taxa de superelevação não deve ser utilizada em locais com incidência de veículos lentos, nem em locais onde possa ocorrer acúmulo de gelo ou neve no pavimento.

Valor não usual. Rodovias de padrão médio, onde não existam interferências que prejudiquem a velocidade de deslocamento e o $10 \%$ fluxo ininterrupto dos veículos. Também não deve ser utilizada em locais com possibilidade de acúmulo de gelo ou neve na superfície do pavimento.

\begin{tabular}{cc}
\hline Rodovias de padrão elevado ou intermediário, onde possam existir \\
interferências que forcem a redução da velocidade média. Valor \\
máximo recomendado para locais com possibilidade de acúmulo de \\
gelo ou neve na superfície do pavimento.
\end{tabular}

Fonte: Informações extraídas de DNER (1999). 
Em locais com previsão de baixa velocidade de tráfego, como interseções em nível ou dispositivos de canalização de tráfego, a superelevação pode ser desprezada.

Outro fator determinante para garantia da segurança e conforto dos motoristas e usuários da via em geral, principalmente em trechos curvos, é o fator de atrito entre pneus e pavimento. Uma vez que o projeto geométrico tem como objetivo o desenvolvimento de curvas seguras para o tráfego dos veículos, os valores de atrito utilizados para fins de projeto são geralmente inferiores ao atrito lateral máximo disponível anteriormente à ocorrência de derrapagens (AASHTO, 2018). Desta forma, o fator máximo de atrito lateral utilizado para fins de projeto deve ser a parcela do atrito lateral máximo disponível que pode ser utilizado sem que haja desconforto pela maior parte dos motoristas (AASHTO, 2018). Também se considera a existência de uma margem de segurança, especialmente para maiores velocidades de deslocamento, visando reduzir a probabilidade de derrapagem para fora da pista quando houver necessidade de acionamento dos freios durante o percurso nas curvas (KABBACH F. I., Notas de Aula da disciplina PTR-5725, 2017).

A Tabela 5 apresenta os valores máximos de fator de atrito recomendados pelo DNIT (2010) e pela AASHTO (2018), em função da velocidade de deslocamento dos veículos:

Tabela 5 - Coeficientes de atrito em função da velocidade de projeto

\begin{tabular}{ccc}
\hline $\begin{array}{c}\text { Velocidade Diretriz } \\
(\mathbf{k m} / \mathbf{h})\end{array}$ & $\begin{array}{c}\text { Fator de Atrito } \\
\text { Máximo (Fat) } \\
\text { AASHTO }\end{array}$ & $\begin{array}{c}\text { Fator de Atrito } \\
\text { Máximo (Fat) - DNIT }\end{array}$ \\
\hline 15 & 0,40 & - \\
\hline 20 & 0,35 & - \\
\hline 30 & 0,28 & 0,20 \\
\hline 40 & 0,23 & 0,18 \\
\hline 50 & 0,19 & 0,16 \\
\hline 60 & 0,17 & 0,15 \\
\hline 70 & 0,15 & 0,15 \\
\hline 80 & 0,14 & 0,14 \\
\hline 90 & 0,13 & 0,14 \\
\hline 100 & 0,12 & 0,13 \\
\hline 110 & 0,11 & 0,12 \\
\hline 120 & 0,09 & 0,11 \\
\hline 130 & 0,08 & - \\
\hline
\end{tabular}

Fonte: Elaborada pelo Autor. 
Nota-se que, para velocidades iguais ou inferiores a $60 \mathrm{~km} / \mathrm{h}$, os fatores de atrito determinados pelo DNIT para fins de projeto, são relativamente inferiores aos fatores de atrito estabelecidos pela AASHTO. Por outro lado, quando se consideram velocidades iguais ou superiores a $90 \mathrm{~km} / \mathrm{h}$, os fatores de atrito determinados pelo DNIT se tornam inferiores aos estabelecidos pela AASHTO. É possível afirmar então que, para baixas velocidades de projeto (zonas urbanas), o DNIT adota uma postura mais conservadora, ao passo que para altas velocidades (zonas rurais), a AASHTO adota uma posição mais conservadora. Cabe destacar que os valores estabelecidos pelo DNIT são também mais antigos, porém, para este estudo, se torna importante realizar uma comparação entre os padrões estabelecidos no Brasil, com padrões mais atualizados, utilizados em nações mais desenvolvidas.

Considerando os princípios básicos da mecânica, a equação abaixo é comumente utilizada para determinação do raio de curvatura horizontal:

$$
R \geq \frac{V^{2}}{g \cdot(f+e)}
$$

Onde:

$$
\begin{aligned}
& R=\text { Raio da curva circular (metros); } \\
& V=\text { Velocidade de projeto }(\mathrm{m} / \mathrm{s}) ; \\
& g=\text { Aceleração da gravidade }\left(\mathrm{m} / \mathrm{s}^{2}\right) ; \\
& \mathrm{f}=\text { Coeficiente de atrito lateral pneu-pavimento (adimensional); } \\
& \mathrm{e}=\text { Superelevação }(\%) .
\end{aligned}
$$

Da posse dos valores máximos admissíveis para a superelevação e fator de atrito, torna-se possível calcular os raios mínimos de curvatura admissíveis e/ou as velocidades máximas admissíveis para qualquer curva circular existente. Os raios mínimos de curvatura horizontal são os menores raios das curvas que podem ser percorridas com a velocidade diretriz e a taxa máxima de superelevação e atrito em condições adequadas de conforto e segurança. 
A Tabela 6 apresenta os raios mínimos de curvas circulares de acordo com a velocidade diretriz do segmento, para os fatores de atrito adotados no Brasil pelo DNIT (2010) e nos Estados Unidos pela AASHTO (2018).

Recomenda-se a utilização dos raios mínimos de curvatura apenas em casos em que não existe a possiblidade de utilização de raios com valores superiores, devido ao ambiente em que a via se insere. Entretanto, sempre que possível, é desejável a utilização de raios superiores ao mínimo em favor do conforto e principalmente da segurança dos usuários da via.

A utilização de raios de curva horizontal com valores superiores aos mínimos recomendados causa a redução da aceleração centrífuga, o que permite a redução da superelevação a ser utilizada (ARAKAWA, 2013). De acordo com o Manual de Projeto Geométrico de Rodovias Rurais publicado pelo DNER em 1999, a superelevação para trechos em curva com raio superior ao mínimo pode ser calculada através da equação 2 :

$$
e=e m a ́ x\left(\frac{2 R m i ́ n}{R}-\frac{R m^{\prime} n^{2}}{R^{2}}\right)
$$

Onde:

$\mathrm{e}=$ Taxa de superelevação ideal $(\mathrm{m} / \mathrm{m})$;

emáx = Taxa máxima de superelevação admissível $(\mathrm{m} / \mathrm{m})$;

$\mathrm{R}=$ Raio da curva $(\mathrm{m})$;

Rmín = Raio mínimo para a taxa de superelevação adotada para a velocidade diretriz em questão $(m)$. 
Tabela 6 - Raios mínimos de curvatura

\begin{tabular}{|c|c|c|c|c|c|c|}
\hline $\begin{array}{l}\text { Velocidade } \\
\text { Diretriz } \\
(\mathbf{k m} / \mathbf{h})\end{array}$ & $\begin{array}{l}\text { Superelevação } \\
\text { máxima "e" (\%) }\end{array}$ & $\begin{array}{c}\text { Fator de } \\
\text { Atrito } \\
\text { máximo } \\
\text { "f" (DNIT, } \\
\text { 2010) } \\
\end{array}$ & $\begin{array}{c}\text { Fator de } \\
\text { Atrito } \\
\text { máximo "f" } \\
\text { (AASHTO, } \\
\text { 2018) } \\
\end{array}$ & $\begin{array}{c}\text { Raio } \\
\text { mínimo } \\
\text { adotado } \\
\text { DNIT }(m)\end{array}$ & $\begin{array}{c}\text { Raio } \\
\text { mínimo } \\
\text { adotado } \\
\text { AASHTO } \\
(\mathrm{m}) \\
\end{array}$ & Diferença \\
\hline 15 & 4 & - & 0,40 & - & 4,0 & - \\
\hline 15 & 6 & - & 0,40 & - & 4,0 & - \\
\hline 15 & 8 & - & 0,40 & - & 4,0 & - \\
\hline 15 & 10 & - & 0,40 & - & 4,0 & - \\
\hline 15 & 12 & - & 0,40 & - & 3,0 & - \\
\hline 20 & 4 & - & 0,35 & - & 8,0 & - \\
\hline 20 & 6 & - & 0,35 & - & 8,0 & - \\
\hline 20 & 8 & - & 0,35 & - & 7,0 & - \\
\hline 20 & 10 & - & 0,35 & - & 7,0 & - \\
\hline 20 & 12 & - & 0,35 & - & 7,0 & - \\
\hline 30 & 4 & 0,20 & 0,28 & 30,0 & 22,0 & 8,0 \\
\hline 30 & 6 & 0,20 & 0,28 & 27,0 & 21,0 & 6,0 \\
\hline 30 & 8 & 0,20 & 0,28 & 25,0 & 20,0 & 5,0 \\
\hline 30 & 10 & 0,20 & 0,28 & 24,0 & 19,0 & 5,0 \\
\hline 30 & 12 & 0,20 & 0,28 & 22,0 & 18,0 & 4,0 \\
\hline 40 & 4 & 0,18 & 0,23 & $\overline{57,0}$ & 47,0 & $\overline{10,0}$ \\
\hline 40 & 6 & 0,18 & 0,23 & 52,0 & 43,0 & 9,0 \\
\hline 40 & 8 & 0,18 & 0,23 & 48,0 & 41,0 & 7,0 \\
\hline 40 & 10 & 0,18 & 0,23 & 45,0 & 38,0 & 7,0 \\
\hline 40 & 12 & 0,18 & 0,23 & 42,0 & 36,0 & 6,0 \\
\hline 50 & 4 & 0,16 & 0,19 & 98,0 & 86,0 & 12,0 \\
\hline 50 & 6 & 0,16 & 0,19 & 89,0 & 79,0 & 10,0 \\
\hline 50 & 8 & 0,16 & 0,19 & 82,0 & 73,0 & 9,0 \\
\hline 50 & 10 & 0,16 & 0,19 & 76,0 & 68,0 & 8,0 \\
\hline 50 & 12 & 0,16 & 0,19 & 70,0 & 64,0 & 6,0 \\
\hline 60 & 4 & 0,15 & 0,17 & 149,0 & 135,0 & 14,0 \\
\hline 60 & 6 & 0,15 & 0,17 & 135,0 & 123,0 & 12,0 \\
\hline 60 & 8 & 0,15 & 0,17 & 123,0 & 113,0 & 10,0 \\
\hline 60 & 10 & 0,15 & 0,17 & 113,0 & 105,0 & 8,0 \\
\hline 60 & 12 & 0,15 & 0,17 & 105,0 & 98,0 & 7,0 \\
\hline
\end{tabular}


Tabela 6 - Raios mínimos de curvatura

\begin{tabular}{|c|c|c|c|c|c|c|}
\hline $\begin{array}{c}\text { Velocidade } \\
\text { Diretriz } \\
(\mathbf{k m} / \mathbf{h})\end{array}$ & $\begin{array}{l}\text { Superelevação } \\
\text { máxima "e" (\%) }\end{array}$ & $\begin{array}{l}\text { Fator de } \\
\text { Atrito } \\
\text { máximo } \\
\text { "f" (DNIT, } \\
2010)\end{array}$ & $\begin{array}{c}\text { Fator de } \\
\text { Atrito } \\
\text { máximo "f" } \\
\text { (AASHTO, } \\
\text { 2018) }\end{array}$ & $\begin{array}{l}\text { Raio } \\
\text { mínimo } \\
\text { adotado } \\
\text { DNIT (m) }\end{array}$ & $\begin{array}{c}\text { Raio } \\
\text { mínimo } \\
\text { adotado } \\
\text { AASHTO } \\
(\mathrm{m})\end{array}$ & Diferença \\
\hline 70 & 4 & 0,15 & 0,15 & 203,0 & 203,0 & 0,0 \\
\hline 70 & 6 & 0,15 & 0,15 & 184,0 & 184,0 & 0,0 \\
\hline 70 & 8 & 0,15 & 0,15 & 168,0 & 168,0 & 0,0 \\
\hline 70 & 10 & 0,15 & 0,15 & 154,0 & 154,0 & 0,0 \\
\hline 70 & 12 & 0,15 & 0,15 & 143,0 & 143,0 & 0,0 \\
\hline 80 & 4 & 0,14 & 0,14 & 280,0 & 280,0 & 0,0 \\
\hline 80 & 6 & 0,14 & 0,14 & 252,0 & 252,0 & 0,0 \\
\hline 80 & 8 & 0,14 & 0,14 & 229,0 & 229,0 & 0,0 \\
\hline 80 & 10 & 0,14 & 0,14 & 210,0 & 210,0 & 0,0 \\
\hline 80 & 12 & 0,14 & 0,14 & 194,0 & 194,0 & 0,0 \\
\hline 90 & 4 & 0,14 & 0,13 & 354,0 & 375,0 & 21,0 \\
\hline 90 & 6 & 0,14 & 0,13 & 319,0 & 336,0 & 17,0 \\
\hline 90 & 8 & 0,14 & 0,13 & 290,0 & 304,0 & 14,0 \\
\hline 90 & 10 & 0,14 & 0,13 & 266,0 & 277,0 & 11,0 \\
\hline 90 & 12 & 0,14 & 0,13 & 245,0 & 255,0 & 10,0 \\
\hline 100 & 4 & 0,13 & 0,12 & 463,0 & 492,0 & 29,0 \\
\hline 100 & 6 & 0,13 & 0,12 & 414,0 & 437,0 & 23,0 \\
\hline 100 & 8 & 0,13 & 0,12 & 375,0 & 394,0 & 19,0 \\
\hline 100 & 10 & 0,13 & 0,12 & 342,0 & 358,0 & 16,0 \\
\hline 100 & 12 & 0,13 & 0,12 & 315,0 & 328,0 & 13,0 \\
\hline 110 & 6 & 0,12 & 0,11 & 529,0 & 560,0 & 31,0 \\
\hline 110 & 8 & 0,12 & 0,11 & 476,0 & 501,0 & 25,0 \\
\hline 110 & 10 & 0,12 & 0,11 & 433,0 & 454,0 & 21,0 \\
\hline 110 & 12 & 0,12 & 0,11 & 397,0 & 414,0 & 17,0 \\
\hline 120 & 6 & 0,11 & 0,09 & 667,0 & 756,0 & 89,0 \\
\hline 120 & 8 & 0,11 & 0,09 & 597,0 & 667,0 & 70,0 \\
\hline 120 & 10 & 0,11 & 0,09 & 540,0 & 597,0 & 57,0 \\
\hline 120 & 12 & 0,11 & 0,09 & 493,0 & 540,0 & 47,0 \\
\hline 130 & 6 & - & 0,08 & - & 951,0 & - \\
\hline 130 & 8 & - & 0,08 & - & 832,0 & - \\
\hline 130 & 10 & - & 0,08 & - & 739,0 & - \\
\hline 130 & 12 & - & 0,08 & - & 665,0 & - \\
\hline
\end{tabular}


Considerando-se a restauração de rodovias existentes, o valor necessário para superelevação, por questões de segurança, pode ser verificado através da seguinte equação 3:

$$
e \geq \frac{V^{2}}{127 . R}-f
$$

Onde:

e = Superelevação indispensável $(\mathrm{m} / \mathrm{m})$;

$\mathrm{V}=$ Velocidade predominante de operação no trecho $(\mathrm{km} / \mathrm{h})$;

$R=$ Raio da curva $(m)$;

$f=$ Coeficiente de atrito lateral máximo admissível (adimensional).

Através da equação 2, é possível inferir que, quanto maior for o raio da curva, menor será a demanda por superelevação, sendo que valores de raio tendendo ao infinito (tangentes) levam a valores de superelevação praticamente nulos. Este fato se justifica na medida em que nos trechos em tangente não existe a atuação da força centrípeta e necessidade de contrabalanceamento da força centrífuga. Entretanto, com o objetivo de facilitar a drenagem superficial de águas pluviais, reduzindo assim a probabilidade do fenômeno de hidroplanagem, que será discutido adiante, os trechos em tangente devem sempre apresentar declividade mínima transversal de $2 \%$, sendo este valor considerado adequado para as condições brasileiras em geral (DNER,1999).

Outro aspecto relevante a ser considerado no desenvolvimento de projetos geométricos são as curvas reversas, definidas como a sucessão de duas curvas circulares de sentidos opostos. O grande problema relativo à segurança viária neste caso reside no fato da formação de uma extensa lâmina d'água na superfície do pavimento, haja vista que para conformação das superelevações opostas é possível existir pontos com declividade transversal e longitudinal igual a zero. A Figura 9 exemplifica a ocorrência deste fenômeno. 
Figura 9 - Desenvolvimento de curvas reversas com formação da lâmina d'água em função da transição de superelevação

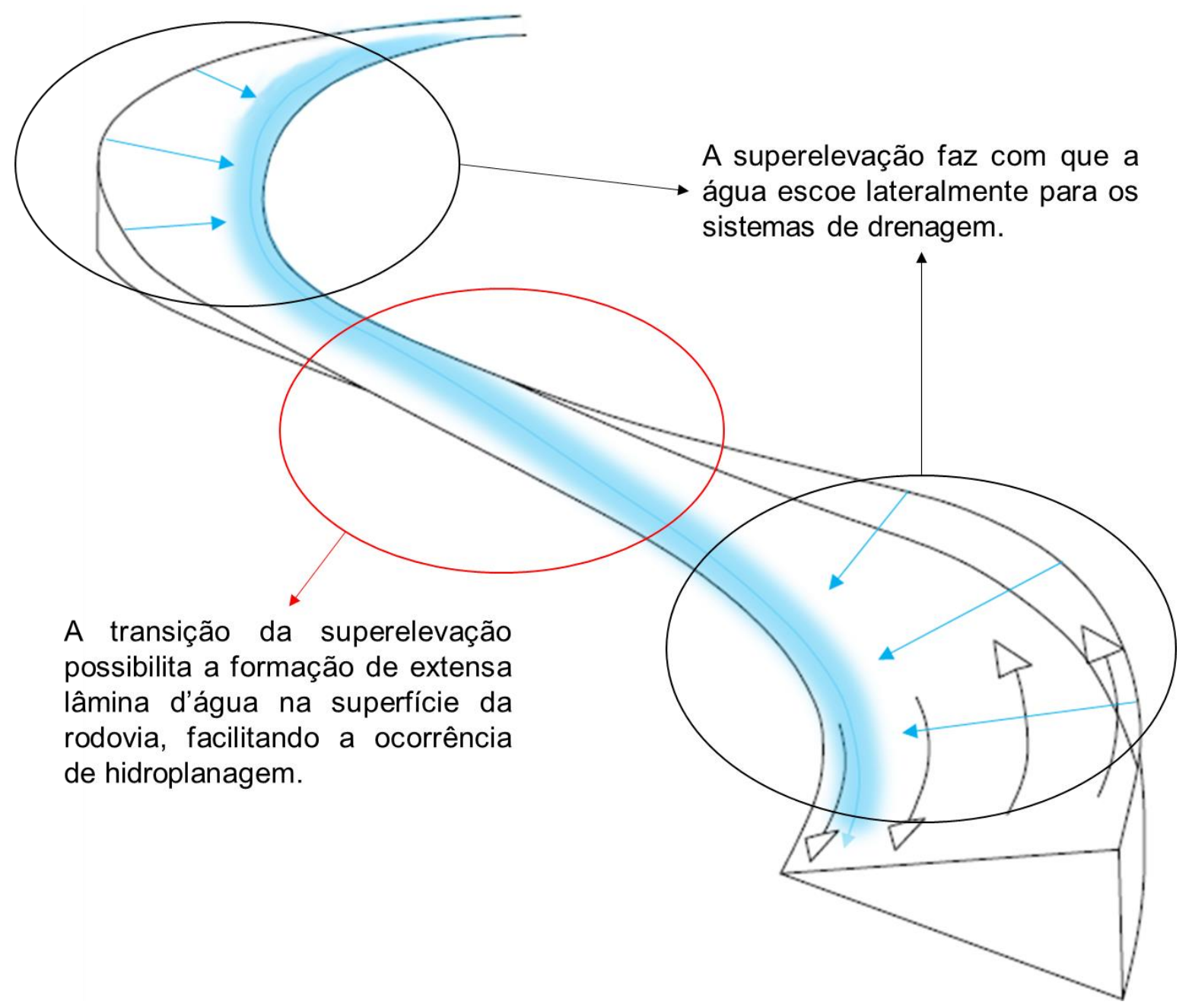

Fonte: Elaborada pelo Autor

A formação desta extensa lâmina d'agua favorece a ocorrência da hidroplanagem, uma vez que sua extensão geralmente é superior ao comprimento dos veículos, permitindo que todas suas rodas se posicionem sobre esta lâmina, podendo reduzir drasticamente o contato entre pneus e pavimento, o que pode causar a perda de controle do veículo por parte dos motoristas. 


\subsubsection{Condições do Pavimento}

De acordo com Bernucci et al. (2010), um pavimento deve garantir, em qualquer época do ano e sob qualquer condição climática, condições adequadas de trafegabilidade, de forma a proporcionar aos usuários conforto ao rolamento e segurança.

A presença de defeitos nos pavimentos afeta diretamente a qualidade ao rolamento, contribuindo indiretamente para a distração dos motoristas, prejudicando a operação dos veículos e facilitando a ocorrência de acidentes (VINAYAKAMURTHY, 2017). Em síntese, alguns defeitos pioram os índices de irregularidade dos pavimentos, o que prejudica a estabilidade dos veículos, podendo em alguns casos reduzir a área de contato entre pneus e pavimento, e alguns defeitos prejudicam as condições de atrito, facilitando a perda de controle quando há frenagem ou desvios de direção emergenciais (VINAYAKAMURTHY, 2017).

Alguns exemplos de patologias que causam a piora das condições de segurança nos pavimentos são: irregularidade elevada, em função da presença de afundamentos em trilha de roda, da existência de panelas/buracos ou devido a falhas no processo construtivo; e redução de atrito, em função da ocorrência de exsudação, do polimento dos agregados pela ação do tráfego, ou pela utilização de materiais inadequados ou com falhas de dosagem, que alteram a textura superficial.

A medição da irregularidade de um pavimento pode ser realizada e expressa através de um índice internacional, designado de IRI - International Roughness Index (índice de irregularidade internacional), que se trata de um parâmetro estatístico expresso em m/km (Bernucci et al., 2010). Quanto maior for o IRI de um segmento, maiores são os desvios da superfície do pavimento em relação à superfície de projeto, teoricamente plana.

Estudo realizado por Al-masaeid (1997) verificou a relação entre a irregularidade de pavimentos e a ocorrência de acidentes rodoviários. O autor chegou à conclusão de que o aumento no IRI dos pavimentos pode causar a redução da ocorrência de acidentes que ocorrem com um único veículo, uma vez que pavimentos irregulares reduzem a velocidade média de operação dos veículos. Todavia, o autor verificou que elevados 
valores de IRI causam o aumento na probabilidade de ocorrência de acidentes com múltiplos veículos, devido à ocorrência de deslocamentos laterais e diferenças de velocidade entre os veículos. A Figura 10 ilustra o risco estimado de ocorrência de acidentes envolvendo veículos únicos e múltiplos veículos de acordo com o IRI do pavimento.

Figura 10 - Risco de acidentes em relação ao IRI do pavimento

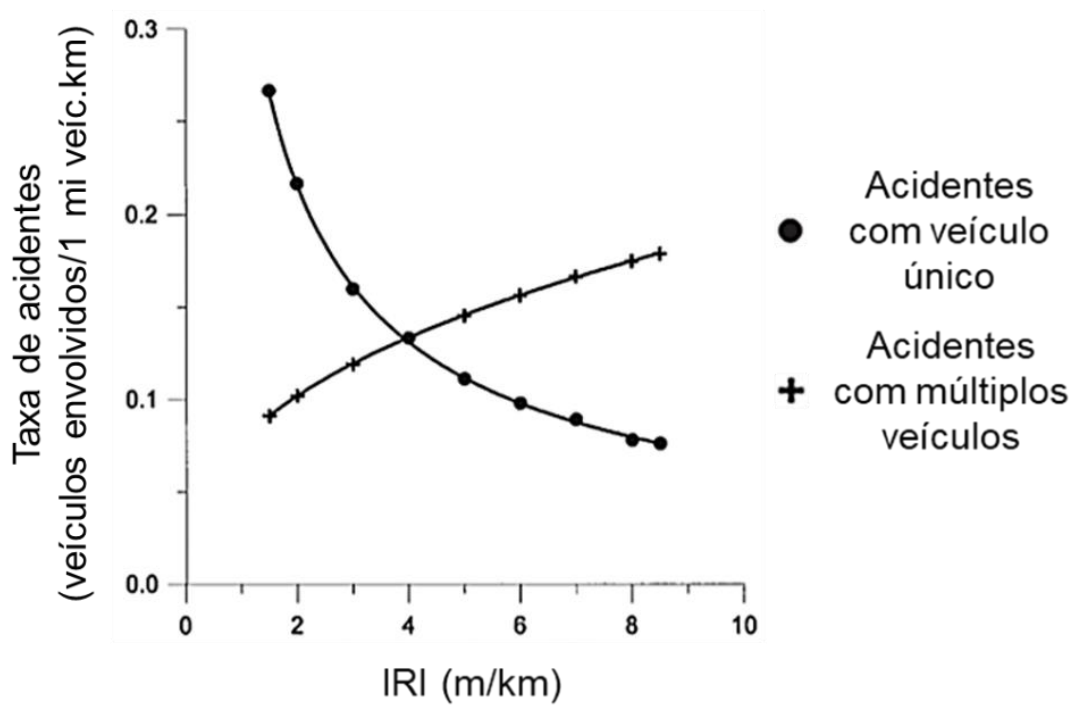

Fonte: Al-Masaeid (1997)

Os afundamentos em trilha de roda (ATR), ou rutting na língua inglesa, afetam diretamente a irregularidade dos pavimentos, e derivam do acúmulo de deformações permanentes nos revestimentos asfálticos ou nas camadas de base, sub-base ou subleito do pavimento, decorrente do esforço de carregamento repetitivo do tráfego (FERREIRA, 2017). De acordo com Bernucci et al. (2010), as principais causas desta patologia são: densificação ou ruptura por cisalhamento das camadas subjacentes ao revestimento, deficiências construtivas como falta de compactação e problemas de drenagem, falhas no procedimento de dosagem e de produção da mistura asfáltica (como emprego de ligante asfáltico inadequado às condições climáticas e de tráfego do local de execução da obra, e utilização de ligante asfáltico em quantidade superior à necessária para atendimento aos parâmetros volumétricos). Esta patologia, além de indicar um grave 
problema estrutural dos pavimentos, também trata de um problema crítico de segurança viária. Esta afirmativa se sustenta na medida em que a presença de afundamentos em trilhos de roda gera caminhos preferenciais às rodas dos veículos, forçando sua trajetória ao longo da via e exigindo um maior esforço dos motoristas para manobrar os veículos, principalmente quando há a necessidade em alterar sua trajetória (FERREIRA, 2017; VINAYAKAMURTHY, 2017). Além disso, o afundamento se torna ainda mais perigoso em períodos chuvosos, uma vez que permitem o acúmulo da água das chuvas exatamente nos locais preferenciais de contato pneu/pavimento, podendo facilitar a ocorrência de hidroplanagem, conforme ilustrado na Figura 11 (VINAYAKAMURTHY, 2017). Por este motivo, para as rodovias federais brasileiras concedidas à iniciativa privada, a Agência Nacional de Transportes Terrestres (ANTT) determina, através de seu Programa de Exploração Rodoviária (PER), que o limite máximo aceitável de afundamento em trilha de roda é igual a 7 milímetros.

Figura 11 - Afundamento em trilha de roda com acúmulo de água

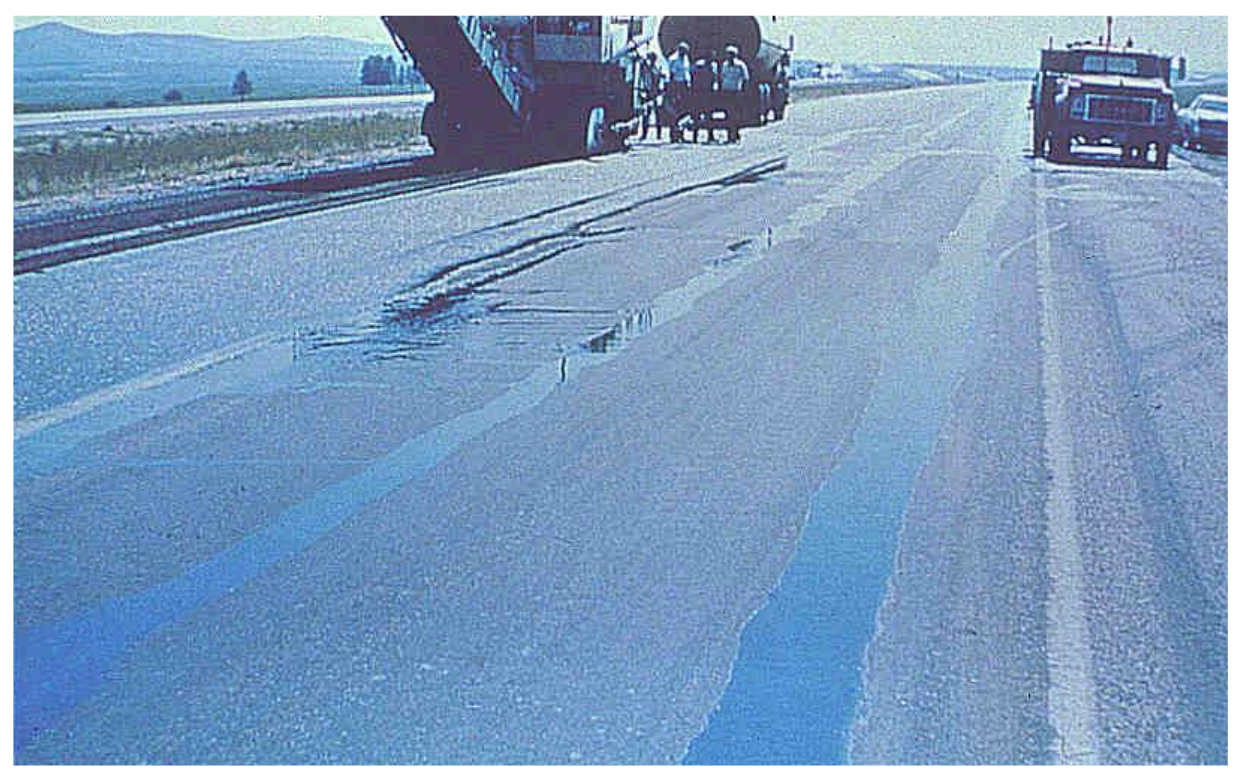

Fonte: Vinayakamurthy, 2017

A presença de buracos, comumente descritos no meio técnico como panelas, colabora para a redução drástica da segurança dos usuários da via. Este defeito, a 
depender de sua dimensão, pode provocar graves danos aos pneus, rodas e suspensão dos veículos, principalmente em vias de trânsito rápido, onde se costuma desenvolver altas velocidades. Desta forma, além de prejudicar as condições de regularidade dos pavimentos, este defeito contribui para que os motoristas alterem constantemente a trajetória "natural" dos veículos, o que pode ocasionar a perda de controle, principalmente em condições climáticas adversas. A Figura 12 ilustra a ocorrência deste defeito. Bernucci et al. (2010) cita que as principais causas para o surgimento deste tipo de patologia nos pavimentos são: evolução de trincas interligadas, onde a ação do tráfego e das intempéries causa a remoção do revestimento ou mesmo de parte da base; falha construtiva, como deficiência de compactação, umidade excessiva em camadas de solo, falha na imprimação; desagregação por falha na dosagem, stripping ou ainda segregação.

Figura 12 - Exemplos de buracos no pavimento
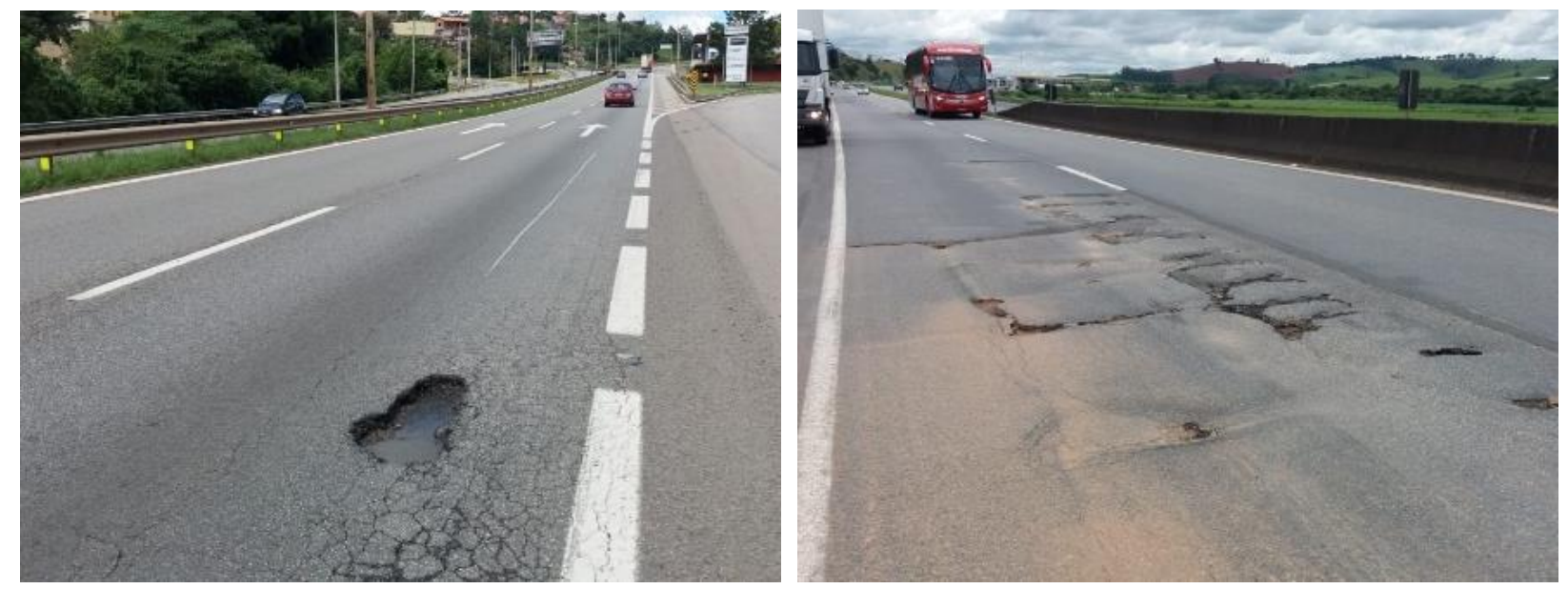

Fotos do Autor

Em relação ao atrito entre pneus e pavimento, dois fatores essenciais garantem sua existência: a textura superficial do pavimento e as características dos pneus dos veículos (BERNUCCI et al., 2010).

De acordo com Hall et al. (2009), a textura do pavimento é definida como os desvios existentes na superfície do pavimento em relação à uma superfície perfeitamente 
plana. Com o intuito de quantificar e de classificar estes desvios, o PIARC (Permanent International Association of Road Congresses, agora denominada World Road Association) criou uma escala de classificação baseada no comprimento de onda dos desvios em relação à superfície perfeitamente plana (BERNUCCI et al., 2010; CALLAI, 2011). A Figura 13 ilustra os vários níveis de textura existentes e a Figura 14 ilustra a escala desenvolvida, bem como os parâmetros que sofrem a influência de cada escala de textura.

Figura 13 - llustração representativa dos diversos tamanhos de textura para a superfície de um pavimento

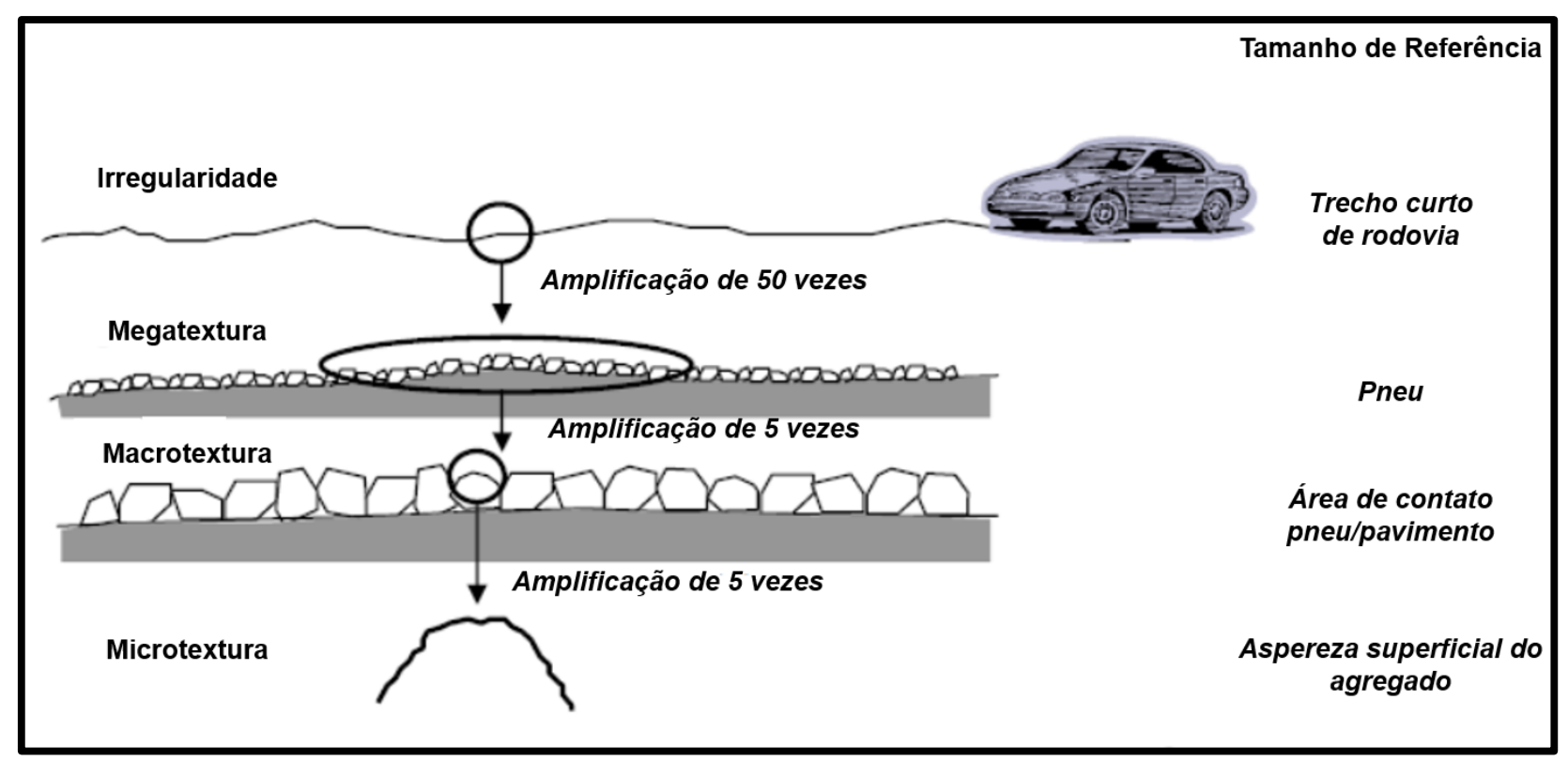

Fonte: Adaptado de Hall et al., 2009 
Figura 14 - Influência da textura superficial na caracterização da superfície dos pavimentos

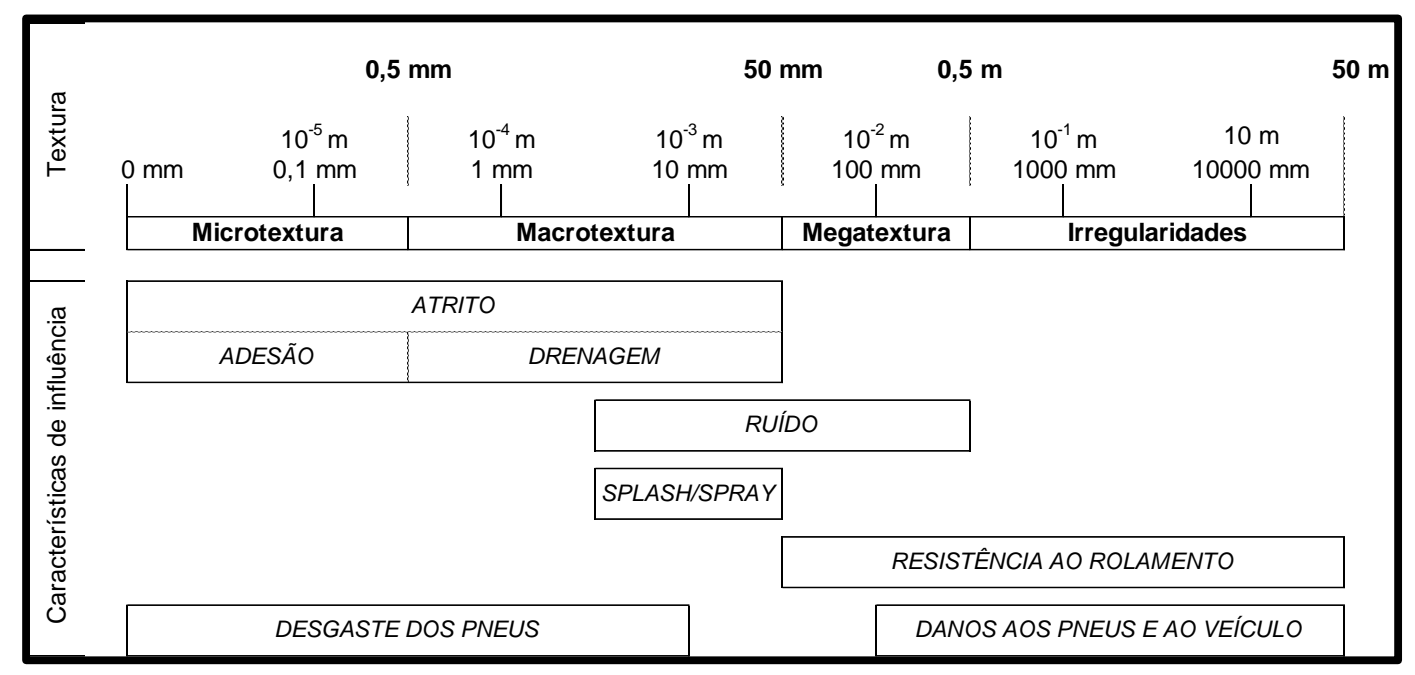

Fonte: Adaptado de Callai (2011)

Conforme pode ser observado na Figura 14, os níveis de textura superficial dos pavimentos que auxiliam na manutenção do atrito são a microtextura e a macrotextura. Segundo Bernucci et al. (2010), a microtextura depende da superfície e da aspereza dos agregados, e a macrotextura é função da rugosidade formada entre agregados e mástique asfáltico (Figura 15). A microtextura é responsável pela manutenção do atrito principalmente em baixas velocidades ( $<40 \mathrm{~km} / \mathrm{h})$, e a macrotextura é responsável pela manutenção do atrito principalmente em altas velocidades e com condições de pavimento molhado (BERNUCCI et al., 2010).

Figura 15 - Representação da microtextura e macrotextura superficial de pavimentos vista em corte

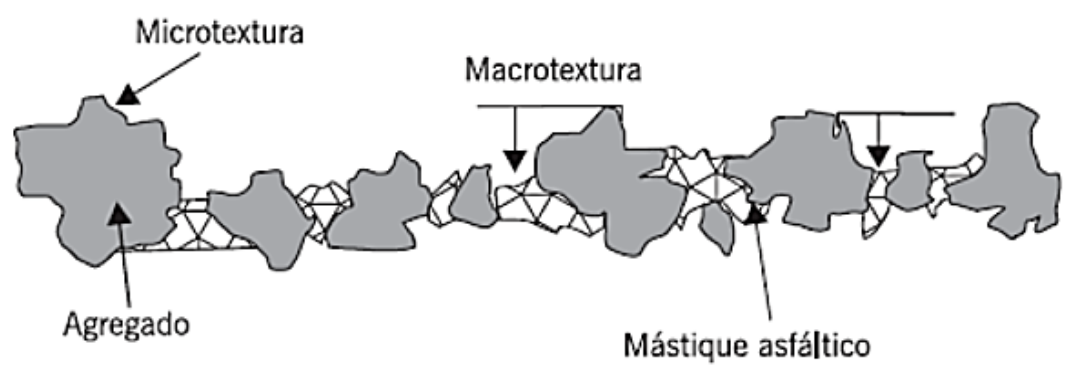

Fonte: Adaptado de Bernucci et al. (2010) 
O atrito resulta de uma interação complexa entre dois componentes, a adesão e a histerese (Figura 16). A adesão é gerada pelo estabelecimento de ligações químicas entre a borracha dos pneus e os agregados do pavimento, sendo função principalmente da área de contato e da força de cisalhamento (HALL et al., 2009). Callai (2011) explica que, quando ocorre a adesão, a borracha do pneu adere ao pavimento, e o atrito é o resultado do posterior rompimento desta ligação. Já a histerese resulta da perda da energia gerada devido à deformação da borracha do pneu pelo contato com a rugosidade superficial do pavimento. Esta deformação é a energia potencial que se armazena na borracha dos pneus, e, à medida em que o pneu relaxa, parte desta energia é recuperada, enquanto a outra parte é dissipada na forma de calor (histerese), sendo este processo irreversível. Esta perda de energia resulta então em uma força de atrito que auxilia a conter o movimento dos pneus (LARSON et al., 2008; HALL et al., 2009; FLINTSCH et al., 2012).

Figura 16 - Principais mecanismos do atrito entre pneu e pavimento

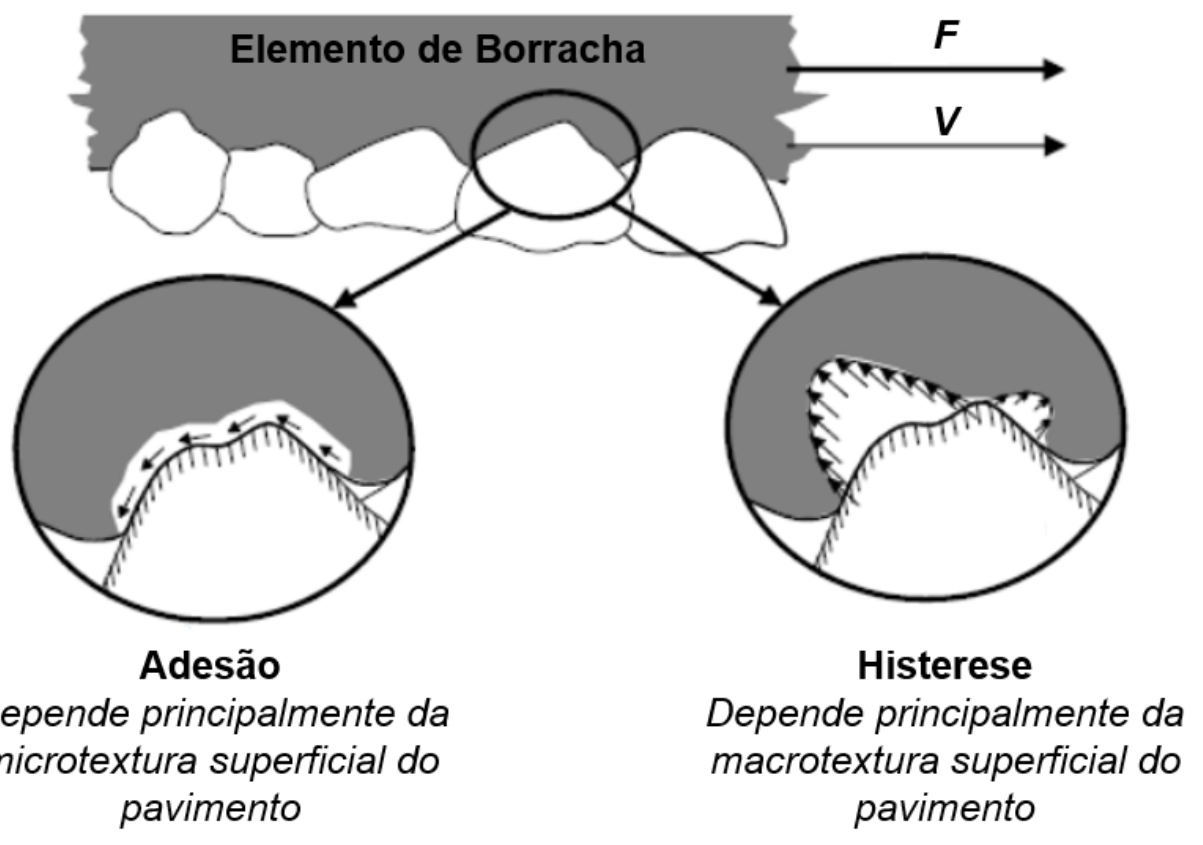

Fonte: Adaptado de Hall et al., 2009. 
Bernucci et al. (2010) explicam que, em condições de pavimento molhado, a microtextura auxilia na quebra da película de água, o que permite o contato pneupavimento, e Hall et al. (2009) elucidam que a macrotextura promove canais de escoamento para a água, auxiliando na drenagem superficial, e garantindo que a superfície dos agregados permaneça exposta sem que exista um contaminante na interface entre pneus e pavimento. A Figura 17 ilustra as condições desejáveis e indesejáveis de microtextura e macrotextura para os pavimentos.

Figura 17 - (a) macrotextura aberta, condição desejável; (b) macrotextura fechada, condição indesejável; (c) microtextura rugosa, condição desejável e; (d) microtextura polida, condição indesejável.

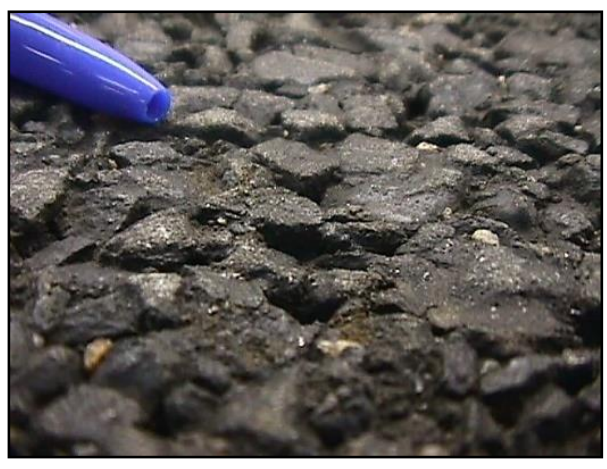

(a)

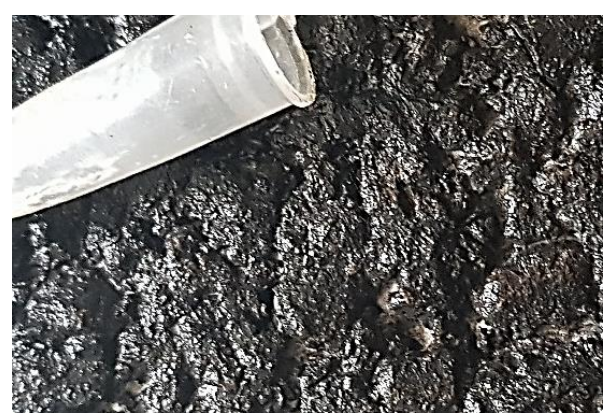

(c)

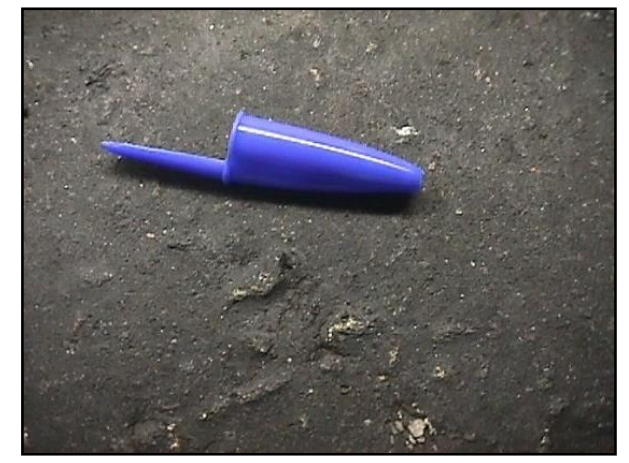

(b)

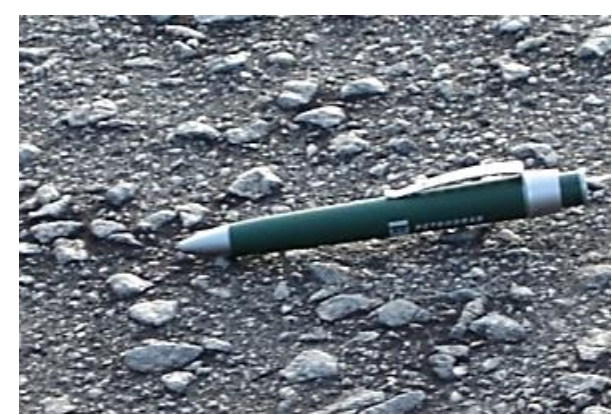

(d)

Fonte: (a) e (b) Edson de Moura, (c) Foto do Autor (d) Bernucci et al. (2010)

Uma vez que o atrito está diretamente relacionado às condições de microtextura e macrotextura, patologias como a exsudação e o polimento dos agregados são altamente prejudiciais para a segurança viária. 
De acordo com Bernucci et al. (2010), a exsudação é caracterizada pela presença de ligante asfáltico em abundância na superfície do pavimento. Esta patologia pode ser identificada através da observação de manchas escurecidas, decorrente em geral do excesso de ligante no material, o que reduz consideravelmente a profundidade da macrotextura do pavimento. Esta patologia também facilita o surgimento de afundamentos em trilhos de roda, devido à fluência do ligante asfáltico. Em relação ao polimento dos agregados, trata-se de uma patologia inevitável, que ocorre devido às ações cíclicas dos pneus dos veículos. Entretanto, o seu surgimento pode ser retardado através da escolha de agregados com adequada resistência a abrasão.

\subsection{Hidroplanagem}

A existência de qualquer tipo de contaminante na interface entre pneu e pavimento levará a um efeito indesejável de redução do atrito disponível. Materiais sólidos e soltos, como a areia, atuam como as esferas em um rolamento, e materiais líquidos atuam como um lubrificante entre um pistão e um cilindro em um motor, reduzindo o atrito entre as duas superfícies. Quanto mais espesso ou mais viscoso o contaminante, maior será a redução do atrito (HALL et al., 2009).

A Hidroplanagem, ou Aquaplanagem, é um fenômeno que ocorre quando os pneus dos veículos perdem o contato com a superfície do pavimento, devido à presença de uma lâmina de água entre estes corpos. Esta perda de contato causa uma redução do atrito disponível para um valor muito próximo a zero, o que impossibilita o controle direcional e o controle de velocidade dos veículos (HALL et al., 2009; APS, 2006). Trata-se de um fenômeno complexo, que pode ser afetado por diversos parâmetros, tais como: (i) espessura da lâmina de água existente na superfície do pavimento; (ii) velocidade de deslocamento do veículo; (iii) macrotextura do pavimento; (iv) profundidade dos sulcos dos pneus; (v) pressão de inflação dos pneus e (vi) área de contato entre pneu e pavimento (HALL et al., 2009). 
Na medida em que um pneu se desloca sobre uma superfície coberta por uma lâmina de água, ele tende a deslocar o fluído para então entrar em contato com o pavimento, o que cria pressões hidrodinâmicas que reagem nas superfícies da pista e do pneu (HORNE; DREHER, 1963). Conforme a velocidade de deslocamento do veículo aumenta, os efeitos de inércia do fluído dificultam/retardam a expulsão da água da interface pneu-pavimento, até certo ponto em que a pressão hidrodinâmica que atua abaixo dos pneus se iguala ao peso atuante, forçando a separação do pneu da superfície do pavimento, conforme ilustrado na Figura 18.

Figura 18 - Hidroplanagem Dinâmica

Peso do veículo

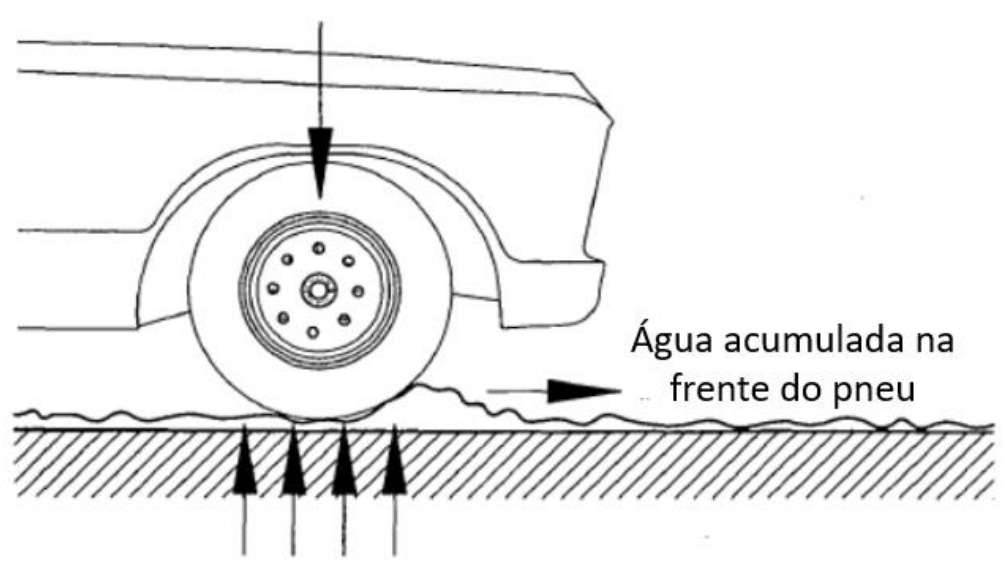

Forças de elevação

Fonte: Adaptado de Mounce; Bartoskewitz, 1993

Em outras palavras, em velocidades elevadas, devido à rapidez de deslocamento, a água não consegue ser eliminada totalmente da interface entre os corpos, ocasionando a separação entre pneu e pavimento. Por este motivo, o risco de ocorrência de hidroplanagem é aumentado conforme a velocidade de deslocamento dos veículos aumenta. A Figura 19 ilustra a redução da área de contato entre pneu e pavimento de acordo com o aumento da velocidade de deslocamento do veículo. 
Figura 19 - Fenômeno da Hidroplanagem

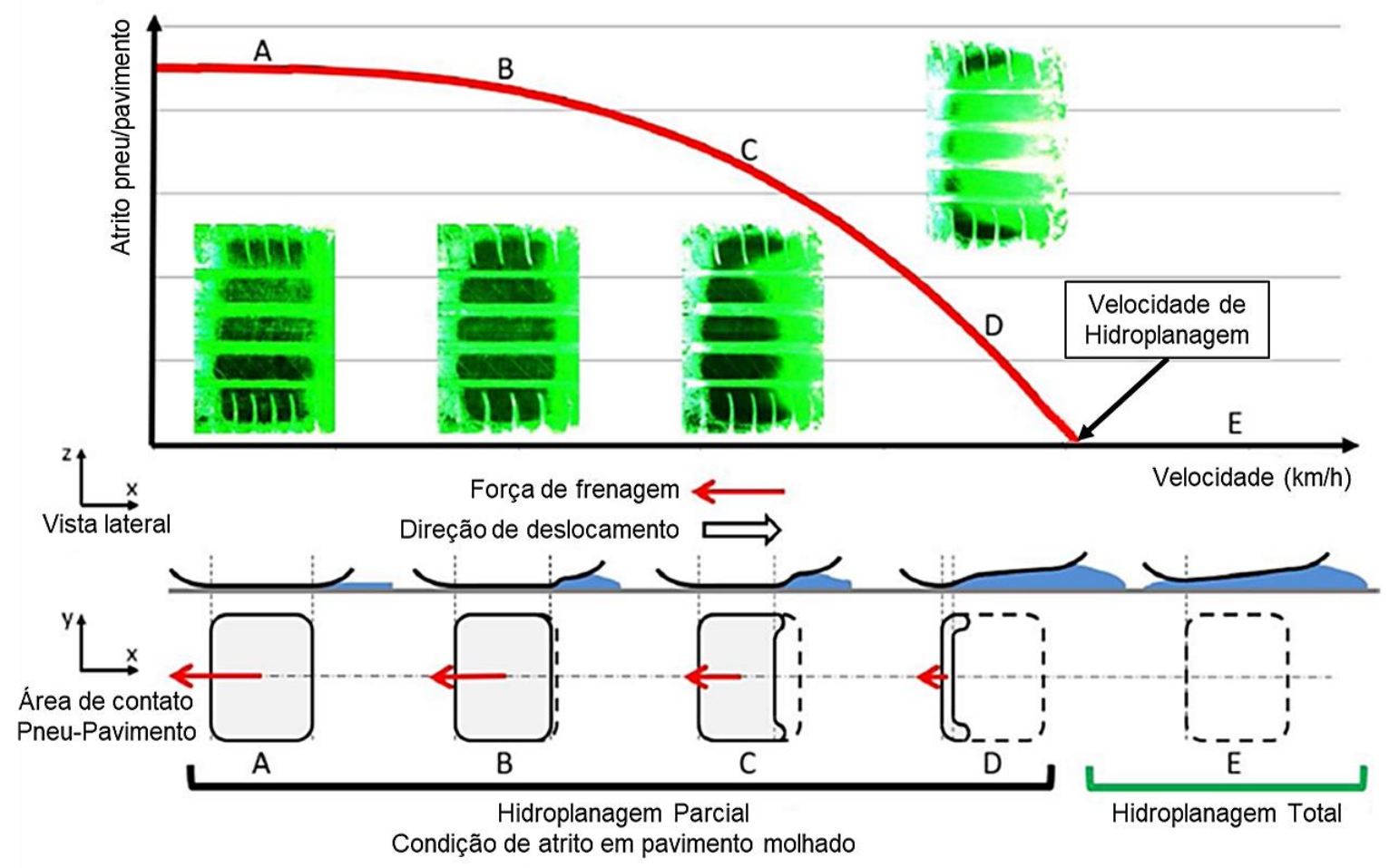

Fonte: Adaptado de SPITZHÜTTL et al. (2020)

Existem 3 tipos de hidroplanagem: (i) hidroplanagem viscosa, (ii) hidroplanagem dinâmica, e (iii) hidroplanagem de borracha revertida (MOUNCE; BARTOSKEWITZ, 1993). Uma vez que a hidroplanagem de borracha revertida é um fenômeno mais comum nos processos de pouso de aeronaves, sendo um fenômeno extremamente raro em acidentes de trânsito, especial atenção deve ser dada aos fenômenos de hidroplanagem viscosa e dinâmica (BUCHARLES, 2014).

A hidroplanagem viscosa ocorre a baixas velocidades e em pavimentos com pouca ou nenhuma microtextura. Este fenômeno resulta da existência de uma espessura de película de água muito fina, da ordem de centésimos de milímetros, devido à insuficiência de microtextura para penetrar e difundir a camada de água. Neste caso, a água passa a agir como um lubrificante, tornando a superfície da pista escorregadia através das pressões hidrostáticas que anulam o atrito na interface pneu/pavimento, erguendo os 
pneus do veículo (BUCHARLES, 2014; MOUNCE; BARTOSKEWITZ, 1993). O seu risco de ocorrência é agravado com o aumento da viscosidade da água, como por exemplo em locais onde há a contaminação por solos, como a argila e o silte (SALPICO, 2009).

A hidroplanagem dinâmica, ao contrário da hidroplanagem viscosa, ocorre em velocidades mais elevadas e devido à existência de uma película espessa de água na superfície do pavimento, geralmente superior à $2,5 \mathrm{~mm}$. Neste caso, a água atua de forma a erguer a banda de rodagem, separando o pneu da superfície do pavimento.

Pesquisas realizadas pela National Aeronautics and Space Administration (NASA), levaram ao entendimento de que a área de contato entre um pneu e um pavimento molhado pode ser subdividida em três zonas distintas, conforme ilustrado na Figura 20 (Silva e Rodrigues Filho, 1981, APUD APS, 2006).

Figura 20 - Zonas de contato na ocorrência da hidroplanagem

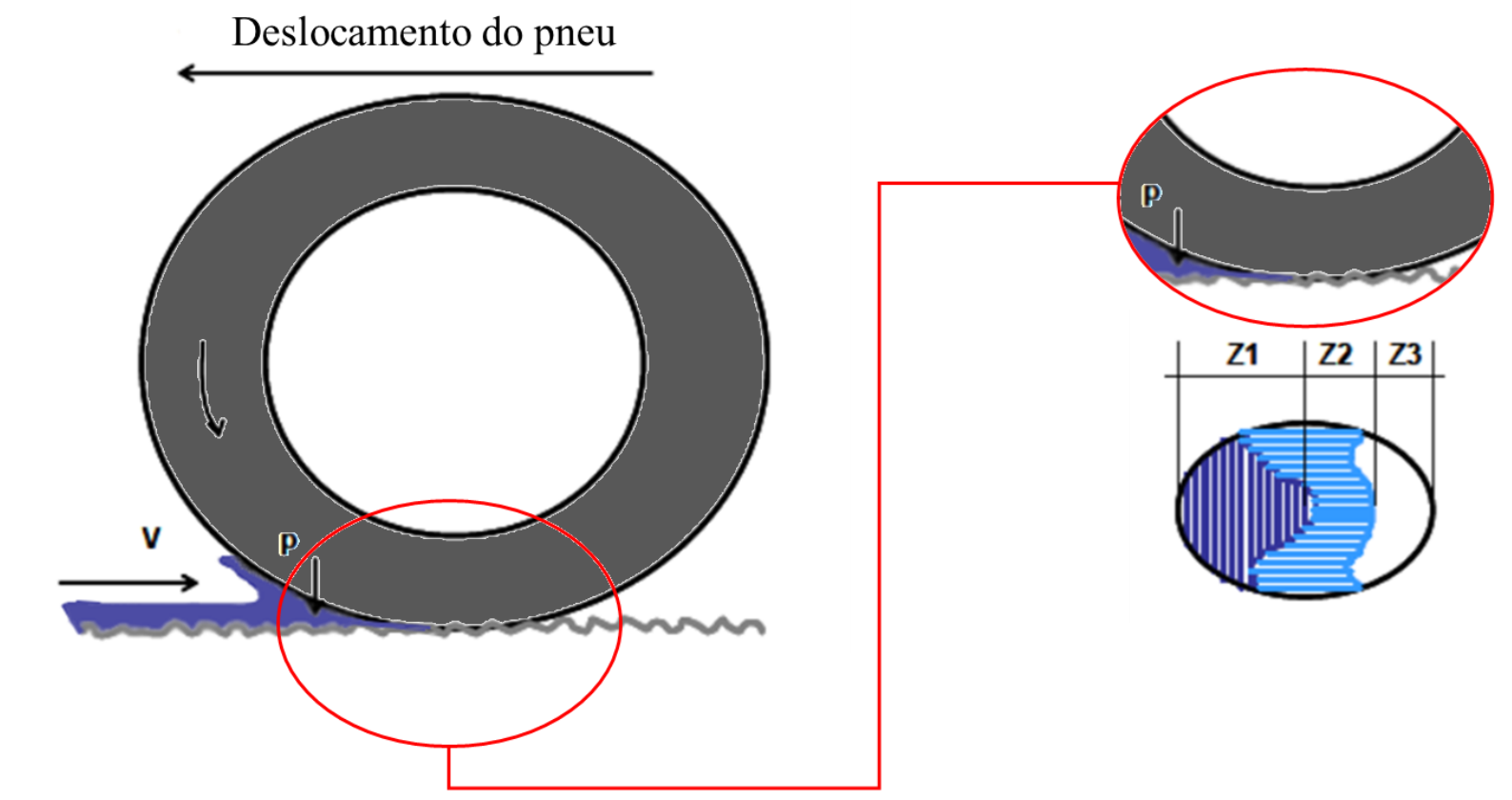

Fonte: Adaptado de APS (2006), a partir de Silva e Rodrigues Filho (1981) e Haas (1994)

A Zona 1, representada por Z1 na Figura 20, denominada também como zona molhada, é a região de contato inicial, sujeita à hidroplanagem dinâmica, onde o pneu se 
depara com uma lâmina de água espessa. Nesta região, o pneu empurra a água para frente, criando uma pequena onda (APS, 2006).

A Zona 2, representada por Z2 na Figura 20, denominada também como zona de transição ou zona intermediária, é a área de contato recoberta por uma lâmina de água delgada, e por este motivo, está sujeita à hidroplanagem viscosa. Aps (2006) cita que, devido à pequena espessura da lâmina d'água, o pneu passa a ter contato parcial com o pavimento.

A Zona 3, representada por Z3 na Figura 20, é a região onde o pneu consegue estabelecer, teoricamente, contato total com o pavimento, sem a presença de lâmina de água. Também denominada de zona seca ou zona de contato, é a área em que 0 atrito existente contribui para a desaceleração e o controle do veículo (APS, 2006).

A porcentagem destas áreas não é constante para todos os casos, sendo dependente da espessura da lâmina d'água, da pressão interna dos pneus, do tipo de manobra que está sendo realizada e principalmente da velocidade de deslocamento (APS, 2006).

A Tabela 7 apresenta resumidamente os fenômenos envolvidos e as propriedades relevantes para cada uma das Zonas descritas anteriormente.

Tabela 7 - Modelo das 3 Zonas - Hidroplanagem Total e Parcial

\begin{tabular}{|c|c|c|c|}
\hline Parâmetros & $\begin{array}{c}\text { Hidroplanagem } \\
\text { Total }\end{array}$ & $\begin{array}{c}\text { Hidroplanagem } \\
\text { Parcial }\end{array}$ & Contato \\
\hline Zona & Z 1 & $\mathrm{Z2}$ & Z3 \\
\hline $\begin{array}{l}\text { Condição } \\
\text { do } \\
\text { Pavimento }\end{array}$ & Molhado & Úmido & Seco \\
\hline $\begin{array}{c}\text { Tipo de } \\
\text { Interação }\end{array}$ & Deslizamento & $\begin{array}{l}\text { Contato } \\
\text { Parcial }\end{array}$ & Rolamento \\
\hline $\begin{array}{c}\text { Propriedade } \\
\text { Relevante }\end{array}$ & Macrotextura & Microtextura & $\begin{array}{c}\text { Macrotextura } \\
\text { e } \\
\text { Microtextura }\end{array}$ \\
\hline $\begin{array}{l}\text { Fenômeno } \\
\text { ocorrente }\end{array}$ & $\begin{array}{l}\text { Hidroplanagem } \\
\text { Dinâmica }\end{array}$ & $\begin{array}{c}\text { Hidroplanagem } \\
\text { Viscosa }\end{array}$ & Atrito \\
\hline
\end{tabular}


Diversos estudos foram realizados buscando o desenvolvimento de fórmulas e critérios para identificação da velocidade exata em que ocorre a hidroplanagem. A abordagem mais comum adotada é a realização do cálculo da velocidade crítica necessária para ocorrência da hidroplanagem dinâmica. Enquanto algumas equações desenvolvidas são relações simples, que definem a velocidade crítica em função de uma ou duas variáveis, existem também equações mais complexas, que abrangem uma maior quantidade de variáveis. Entretanto, como é de se esperar, prever quando a hidroplanagem irá ocorrer, ou identificar se a ocorrência de um acidente em condições de pavimento molhado se deu exclusivamente devido à hidroplanagem, são tarefas bastante difíceis, e que envolvem um elevado grau de incerteza (MOUNCE; BARTOSKEWITZ, 1993).

Estudo desenvolvido por Gallaway et al. (1979) desenvolveu uma equação empírica para cálculo da velocidade crítica de hidroplanagem dinâmica, quando a espessura da lâmina d'água excede $2,5 \mathrm{~mm}$. A equação é apresentada a seguir:

$$
V=0,902 S D^{0,04} P^{0,3}\left(\frac{T D}{0,794}+1\right)^{0,06} A
$$

Onde:

$V=$ Velocidade do veículo $(\mathrm{km} / \mathrm{h})$,

$\mathrm{SD}=$ Spin Down Speed";

$\mathrm{P}=$ Pressão de inflação dos pneus $\left(\mathrm{kN} / \mathrm{m}^{2}\right)$;

TD = Profundidade das ranhuras do pneu $(\mathrm{mm}) ;$

$A=$ maior valor entre A1 e A2, conforme equações (5 e (6:

${ }^{1}$ Spin Down Speed é o termo utilizado para descrever a redução da velocidade de rotação segundo o eixo da roda. Este fenômeno ocorre quando um pneu entra em hidroplanagem e começa a perder rotação devido à pressão da água. Considera-se 10 no início da hidroplanagem. 


$$
\begin{gathered}
A 1=\frac{12,639}{h^{0,06}}+3,507 \\
A 2=\left(\frac{22,351}{h^{0,06}}-4,970\right) \times A a^{0,14}
\end{gathered}
$$

Onde:

$\mathrm{h}=$ Altura de água acima das asperezas do pavimento $(\mathrm{mm})$;

$\mathrm{Aa}=$ Macrotextura do pavimento medida pelo ensaio de mancha de areia $(\mathrm{mm})$.

Ainda de acordo com Gallaway et al. (1979), a altura de água acima das asperezas do pavimento pode ser calculada de acordo com a equação abaixo:

$$
h=0,01485 \times\left(\frac{A a^{0,11} \times L w^{0,43} \times i p^{0,59}}{i w^{0,42}}\right)-A a
$$

Onde:

$\mathrm{h}=$ Altura de água acima das asperezas do pavimento $(\mathrm{m})$

$\mathrm{Lw}=$ Comprimento da linha de água $(\mathrm{m})$

ip = Intensidade de precipitação $(\mathrm{mm})$

iw = Inclinação da linha da água $(\mathrm{m} / \mathrm{m})$

França (1988) cita que, para o cálculo da velocidade crítica de hidroplanagem em casos em que a espessura da lâmina de água acima da rugosidade do pavimento é inferior à 2,5mm, geralmente emprega-se a equação de Agrawall, conforme apresentado abaixo. Os símbolos estão expressos na mesma unidade da equação de Gallaway. 


$$
V=96,899 \times h^{-0.259}
$$

Apenas para efeito ilustrativo, a Figura 21 representa as velocidades críticas de ocorrência de hidroplanagem, de acordo com as equações exibidas acima, e considerando os seguintes dados: Pressão dos pneus $(P)=165 \mathrm{kN} / \mathrm{m}^{2}$; Profundidade das ranhuras do pneu $(T D)=2,54 \mathrm{~mm}$; Macrotextura $(\mathrm{Aa})=0,508 \mathrm{~mm}$.

Figura 21 - Representação gráfica das equações de Gallaway e Agrawall

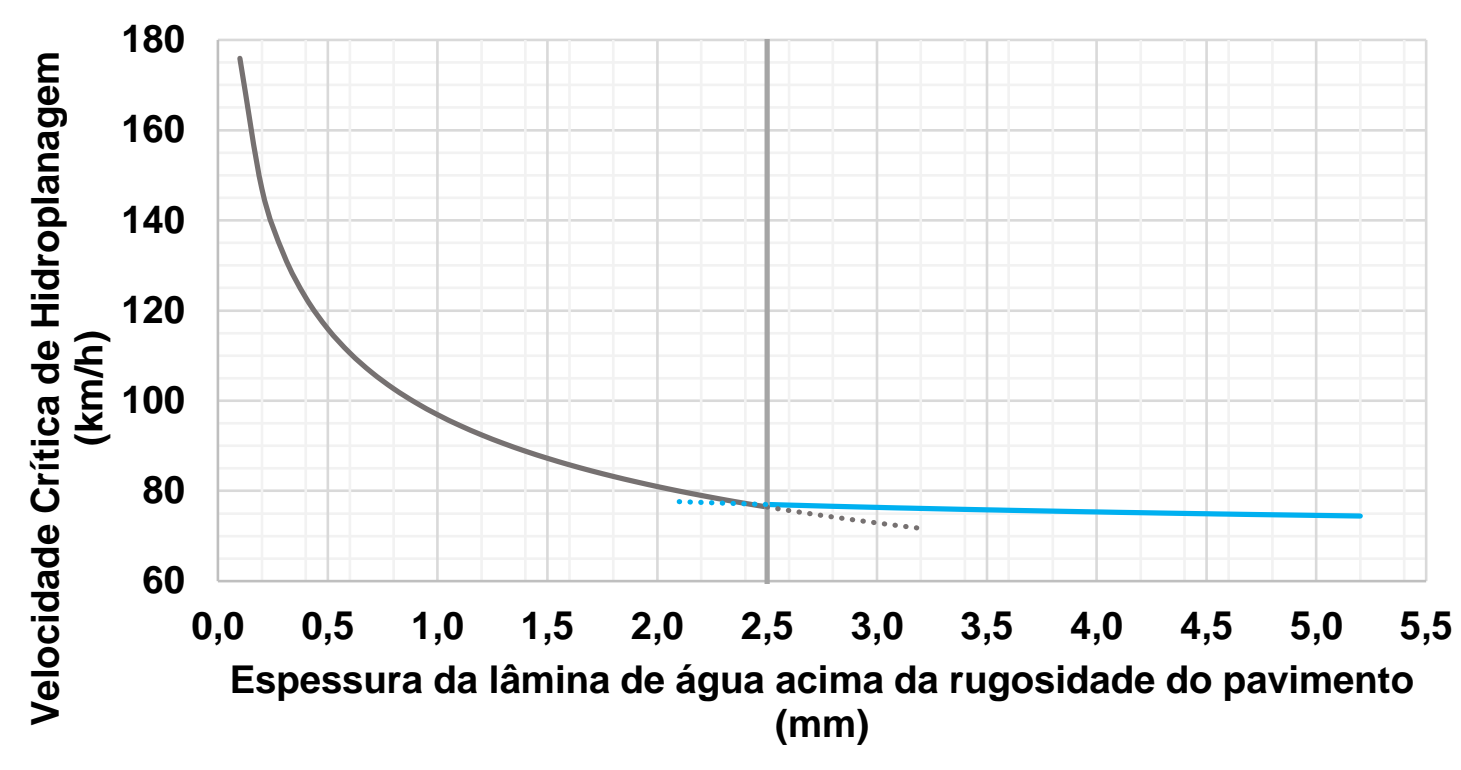

-Agrawall — Gallaway

Fonte: Elaborada pelo Autor

Hall et al. (2009) sugerem um procedimento simples, composto por 3 etapas, para determinação do risco potencial de hidroplanagem para trechos rodoviários.

Primeira Etapa: Estimar a Velocidade Crítica de ocorrência de Hidroplanagem de acordo com a equação 9. Esta equação assume que a lâmina de água existente na superfície do pavimento excede a capacidade combinada da macrotextura e dos sulcos dos pneus para remover a água da superfície do pavimento. 


$$
V h=6,35 \sqrt{P h}
$$

Onde:

$\mathrm{Vh}=$ Velocidade crítica de Hidroplanagem $(\mathrm{km} / \mathrm{h})$;

$\mathrm{Ph}=$ Pressão de inflação dos pneus $(\mathrm{kPa})$.

Segunda Etapa: Calcular a espessura da lâmina de água para o segmento rodoviário, através de modelos ou procedimentos estabelecidos e difundidos no meio técnico, sempre considerando o histórico pluviométrico da região de estudo.

Terceira Etapa: Determinar o risco potencial de hidroplanagem, de acordo com a Tabela 8.

Tabela 8 - Risco potencial de hidroplanagem com base na velocidade dos veículos e na espessura da lâmina de água

\begin{tabular}{cccc}
\hline Velocidade 85 Percentil praticada no trecho estudado, & \multicolumn{3}{c}{ Espessura da Lâmina de água $(\mathrm{mm})$} \\
\cline { 3 - 5 } subtraída a Velocidade Crítica de Hidroplanagem $(\mathrm{km} / \mathrm{h})$ & $<0.508$ & 0.508 a & \multicolumn{1}{c}{1.524} \\
\hline Menor do que -8 & Inexistente & Inexistente & Inexistente \\
\hline entre -8 e +8 & Inexistente & Baixo & Moderado \\
\hline Maior do que +8 & Inexistente & Moderado & Alto \\
\hline
\end{tabular}

Fonte: Adaptado de Hall et al. (2009).

\subsection{Principais soluções de pavimento para redução de acidentes}

Estudos realizados por Kennedy et al. (1990) e Roe et al. (1991), indicam que a textura superficial dos pavimentos tem um grande impacto na ocorrência de acidentes. Não obstante, Pulugurtha, Kusam e Patel (2008) afirmam que valores de macrotextura superiores a $1,5 \mathrm{~mm}$ e inferiores a $3,0 \mathrm{~mm}$ podem auxiliar significativamente na redução de acidentes, devido à capacidade superior de escoamento superficial das águas 
provenientes de precipitações, reduzindo a probabilidade de ocorrência de hidroplanagem e, consequentemente, melhorando a segurança dos usuários da via. Desta forma, o emprego de materiais com elevada textura na camada de revestimento dos pavimentos se mostra uma alternativa promissora no combate à ocorrência de acidentes rodoviários.

As características superficiais dos pavimentos, como a microtextura e a macrotextura, são influenciadas diretamente pelos materiais e pela técnica construtiva utilizados.

No Brasil, o material mais utilizado como camada de revestimento de pavimentos é o Concreto Asfáltico (CA), também denominado como Concreto Betuminoso Usinado a Quente (CBUQ), que se trata de uma mistura entre agregados minerais, de diversos tamanhos, com ligante asfáltico, em proporção adequada para garantia das propriedades desejadas de impermeabilidade, flexibilidade, estabilidade, durabilidade, resistência à fadiga e resistência à derrapagem (BERNUCCl et al., 2010).

Dentre os principais parâmetros de uma mistura asfáltica que influenciam na textura superficial dos pavimentos, e consequentemente na resistência à derrapagem, é possível citar: (i) origem dos agregados, (ii) dimensão e distribuição granulométrica dos agregados, e (iii) teor de ligante asfáltico.

Estudo realizado por Spech et al. (2007) avaliou a macrotextura de diversos tipos de pavimentos através do ensaio de mancha de areia, de acordo com a norma técnica ASTM E965-96. A Figura 22 ilustra os resultados obtidos para cada tipo de pavimento, onde os valores entre parênteses ao lado da indicação do tipo de revestimento representam a quantidade de ensaios realizados. É possível observar que, dentre os diversos tipos de revestimentos avaliados, o Tratamento Superficial Duplo (TSD) foi o que apresentou maiores valores de macrotextura, se mostrando uma alternativa promissora para locais onde há a necessidade de melhoria de atrito, principalmente em condições de pavimento molhado. Entretanto, misturas asfálticas com valores elevados de macrotextura também podem resultar em aumento do desgaste dos pneus dos veículos além do aumento do ruído, caso a textura seja positiva. Por este motivo, as 
especificações brasileiras normalmente sugerem 0 emprego de misturas com profundidade média da mancha de areia variando entre 0,6mm a 1,2mm (DNIT, 2006).

Figura 22 - Comparativo entre a macrotextura de diversos tipos de pavimentos

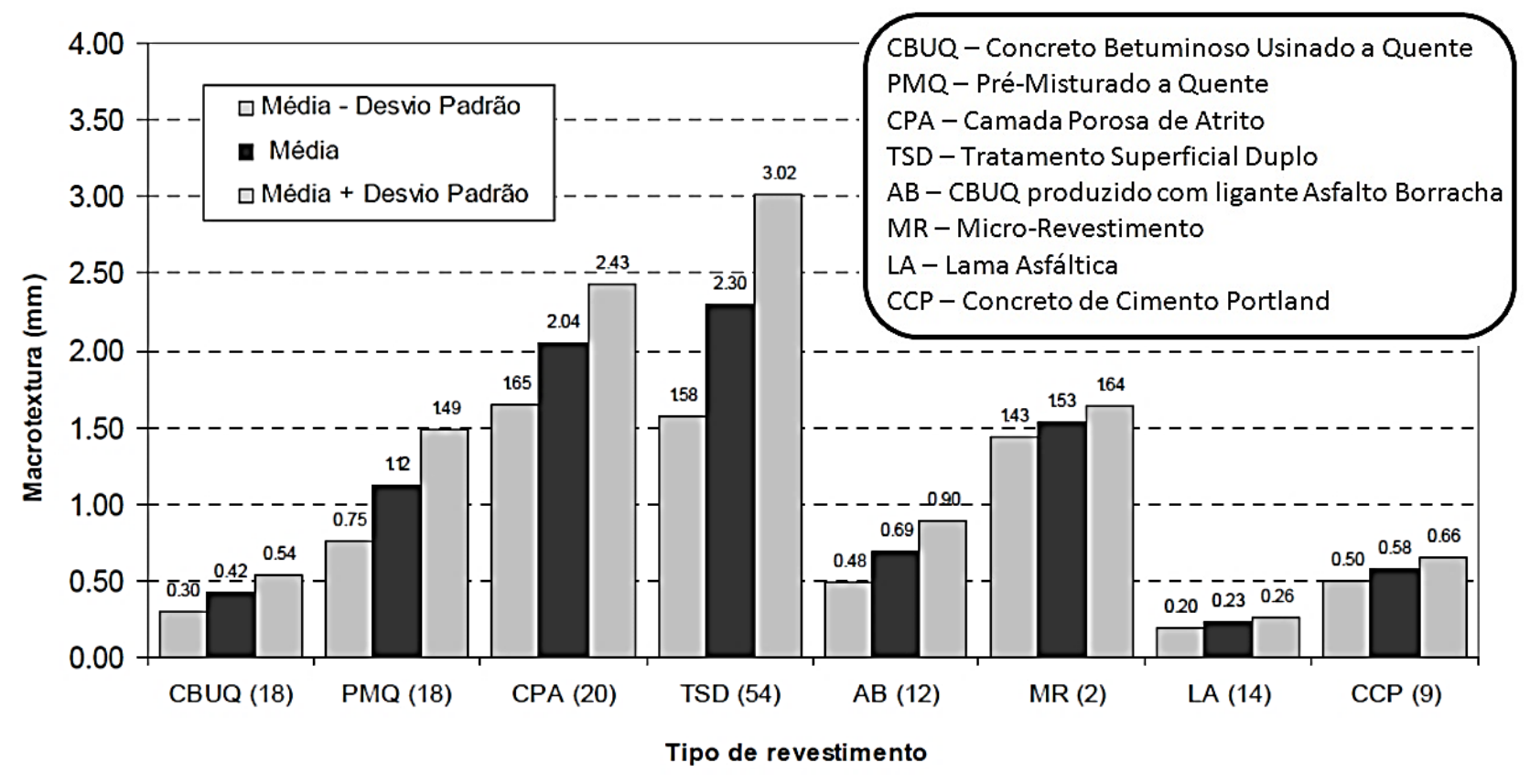

Fonte: Spech et al. (2007)

De acordo com Emeasoba e Ogbuefi (2013), uma das principais vantagens do emprego de soluções de tratamento superficial, é a boa relação custo/benefício em comparação com outras soluções existentes. Esta boa relação custo-benefício se dá, por muitas vezes, devido à baixa espessura da camada. De acordo com Larsen (1985), existem ainda outras vantagens da aplicação deste tipo de revestimento asfáltico, como a impermeabilização da estrutura e o rejuvenescimento de revestimentos asfálticos envelhecidos, além da sua boa resiliência, tornando o trincamento por fadiga praticamente inexistente. Sua maior desvantagem em relação às camadas de concreto asfáltico convencionais é o fato de se tratar de uma camada de desgaste, não devendo ser considerada para fins de dimensionamento da estrutura. 
Ainda de acordo com Larsen (1985), esta técnica não é usual em rodovias de alto volume de tráfego pois, devido a um alto número de insucessos no passado, camadas de Tratamento Superficial adquiriram uma má fama no meio rodoviário. Entretanto, o autor ainda comenta que estes insucessos estavam diretamente relacionados à negligência de diversos fatores relevantes para garantia do bom desempenho da técnica, como a maneira correta de escolha de materiais, da elaboração do projeto e da aplicação em pista. Felizmente, devido ao avanço tecnológico, com o desenvolvimento de equipamentos mais precisos para realização dos serviços, este tipo de solução vem ganhando espaço novamente no meio rodoviário.

Com a modernização da técnica, pode-se dizer que o emprego do tratamento superficial é possível para praticamente todas as categorias de volume e velocidade de tráfego, devendo o engenheiro responsável pela obra se atentar à escolha dos materiais mais adequados para cada condição. Neste sentido, principalmente para zonas de tráfego intenso, com frequentes acelerações e frenagens, deve- optar pelo emprego de ligantes asfálticos modificados e agregados de alta qualidade. 


\section{ESTUDO DE CASO}

A presente dissertação de mestrado possui como principal objetivo apontar solução asfáltica, de viabilidade técnica e econômica, a ser aplicada em segmentos críticos de rodovias de tráfego pesado, para redução da ocorrência de acidentes por derrapagem.

O estudo foi realizado no trecho rodoviário administrado pela concessionária Autopista Régis Bittencourt (Figura 23). A concessionária administra o trecho de 402,6 quilômetros da rodovia federal Régis Bittencourt - BR 116, que faz a ligação das cidades de São Paulo - SP e Curitiba - PR, e possui elevado volume de tráfego (atualmente composto por um expressivo volume de ônibus e caminhões, que representam mais de $60 \%$ do movimento total de veículos em diversos pontos da rodovia).

Figura 23 - Rodovia Régis Bittencourt (BR 116) - Trecho administrado pela Autopista Régis Bittencourt S.A.

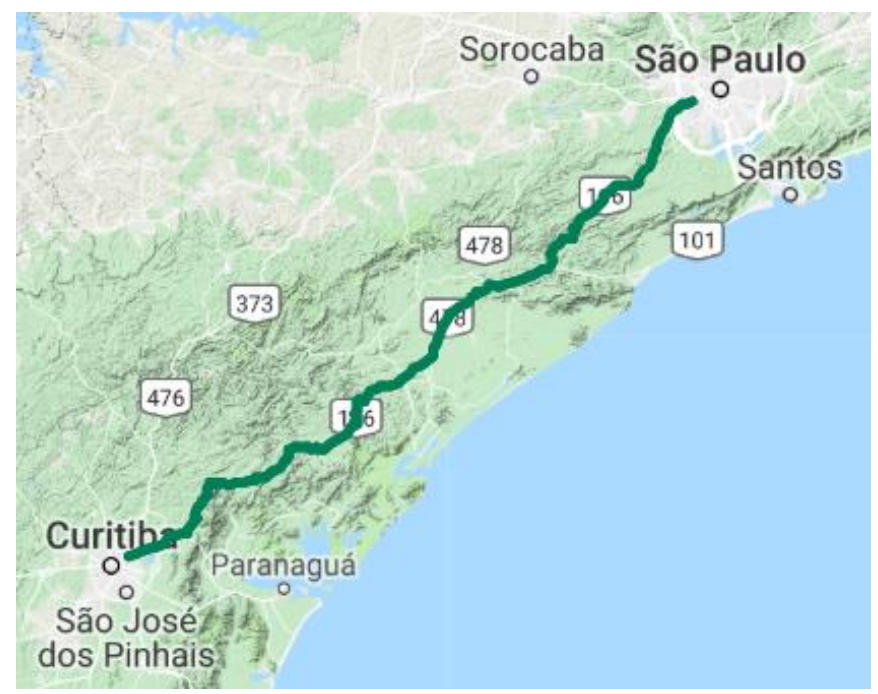

Fonte: Elaborada pelo Autor utilizando a ferramenta Google Maps

O programa experimental deste trabalho pode ser divido em três grandes fases: (i) análise estatística dos dados relativos à ocorrência de acidentes; (ii) definição e implantação da camada asfáltica para melhoria de atrito e; (iii) monitoramento e avaliação de resultados. 
Na primeira fase do estudo, foi realizado um levantamento referente ao registro histórico de ocorrência de acidentes, bem como foram catalogados os dados topográficos disponíveis, dados pluviométricos e dados referentes ao volume horário de tráfego dos diversos segmentos que compõe a rodovia em questão, com a finalidade de realizar uma análise estatística e espacial robusta e precisa, além de melhorar o entendimento da dinâmica de ocorrência de acidentes.

Através das análises estatísticas realizadas, foi possível delimitar os segmentos de maior criticidade, onde a alteração das propriedades superficiais do pavimento se apresentava como uma solução promissora para controle das ocorrências.

Durante a segunda fase da pesquisa, foi necessária a realização de uma visita aos segmentos delimitados através das análises estatística e espacial, com o objetivo de verificar as condições de contorno do local, como as características geométricas e do pavimento, além da predominância ou não de sombras, de forma que fosse escolhida uma solução técnica apropriada, aumentando assim as chances de sucesso. Os materiais para produção da camada asfáltica foram selecionados de acordo com critérios técnicos, visando a garantia de qualidade e durabilidade ao longo do tempo. Foram realizados ensaios para avaliação das propriedades dos agregados pétreos e do ligante asfáltico, de acordo com normas técnicas nacionais e internacionais. Uma vez conferido 0 atendimento às propriedades necessárias, foi realizado o projeto de dosagem dos materiais, de forma a se determinarem as proporções ideais para aplicação em campo. A execução dos serviços contou com equipe técnica especializada, e foi realizado um rigoroso controle tecnológico de aplicação dos materiais.

Já na terceira fase, foram realizados ensaios de monitoramento periódicos para verificação da textura superficial e atrito resultante, e continuou-se o levantamento de dados pluviométricos, de volume de tráfego e de ocorrência de acidentes para verificação da efetividade da solução no controle das ocorrências de acidentes. Também nesta fase, foi identificada a ocorrência de algumas patologias, e foram levantadas as principais limitações da camada asfáltica empregada. Ressaltam-se que foram analisados dados de acidentes desde 2009, início da concessão até dezembro de 2020, totalizando 3 anos 
de monitoramento após a implantação da restauração de superfície para melhoria de atrito e textura.

\subsection{Registro histórico de ocorrência de acidentes na BR-116 (Trecho São Paulo - Curitiba)}

A rodovia Régis Bittencourt foi, por muitos anos, considerada como a "Rodovia da Morte" (MUNDO, 2018). Este fato se dá pela enorme quantidade de acidentes de alta severidade, com fatalidades, ocorridos em seu trecho mais movimentado.

Embora o trecho 'São Paulo - Curitiba' tenha sido inaugurado na década de 1960, não se dispõe do registro policial de ocorrência de acidentes desde sua liberação ao tráfego. Uma das justificativas para a inexistência de dados dos acidentes ocorridos no período anterior à concessão é o fato de que muitos acidentes deixaram de ser registrados e contabilizados, principalmente aqueles ocorridos com veículo único, por falta de interesse dos envolvidos em registrar um boletim de ocorrência.

Desta forma, foram levantados os registros de ocorrências de acidentes a partir do ano de 2009, período em que a rodovia já iniciava seu período sob administração da Autopista Régis Bittencourt do Grupo Arteris, e já haviam sido estabelecidos critérios para registro de todas as ocorrências.

Para delimitação dos segmentos críticos de ocorrência de acidentes, foram disponibilizados, pela concessionária, arquivos digitais em formato compatível com o Excel, contendo as seguintes informações relativas aos acidentes:

- Data e horário de ocorrência dos acidentes: período compreendido entre janeiro de 2009 e dezembro de 2016;

- Localização: informações como estaqueamento da rodovia e coordenadas geográficas;

- Tipo de acidente: classificação de acordo com as definições da norma ABNT NBR 10697 - Pesquisa de acidente de trânsito - Terminologia; 
- Causa provável: indicação dos principais fatores que podem ter contribuído para a ocorrência do acidente;

- Veículos envolvidos: informações relativas à quantidade e tipo de veículos envolvidos;

- Vítimas: informações a respeito da quantidade de vítimas, bem como a gravidade dos ferimentos sofridos;

- Descrição: a descrição de cada acidente foi realizada através dos depoimentos dos motoristas e/ou da percepção do técnico responsável pelo registro da ocorrência;

- Condições climáticas e de visibilidade: informações como a ocorrência ou não de chuvas, nevoeiros, etc., no momento do acidente;

- Traçado de pista: reta (tangente), curva suave ou curva acentuada;

- Perfil da pista: aclive, declive ou em nível;

- Existência ou inexistência de obras na pista

Uma vez que fatores como o volume de tráfego, bem como intensidade, duração e frequência das precipitações também são elementos que podem se relacionar com ocorrência dos acidentes, também foram levantados os registros históricos existentes para auxiliar na delimitação dos segmentos críticos.

Dados de tráfego contabilizados nas cabines de pedágio foram disponibilizados desde o início de 2009, também em arquivo compatível com o Excel. Destaca-se a possibilidade de quantificação dos veículos por tipo (quantidade de eixos), sentido, data e horário.

Em relação aos dados pluviométricos, foram obtidos dados de precipitação horária dos pluviógrafos que foram instalados em todas as praças de pedágio no início de 2014 . A Figura 24 apresenta a localização dos pluviógrafos ao longo da rodovia. 
Figura 24 - Localização dos pluviógrafos instalados nas praças de pedágio da rodovia

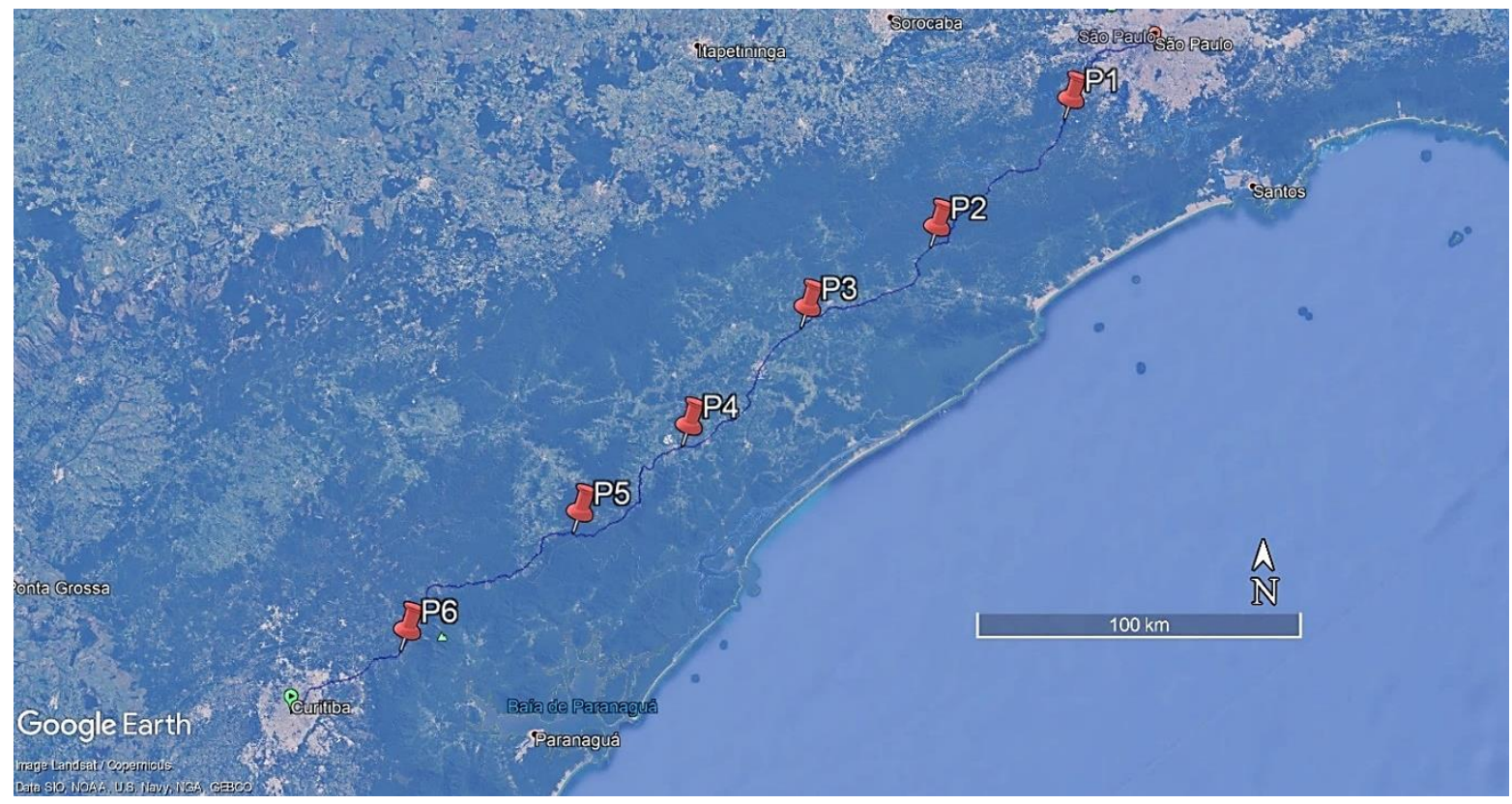

Fonte: Elaborada pelo Autor utilizando a ferramenta Google Maps

Da posse dos arquivos, foi iniciada a avaliação estatística dos dados. A Tabela 9 ilustra a evolução da densidade de acidentes por ano e por sentido de pista.

Tabela 9 - Densidade de acidentes (acidentes/100 mil veículos.km) por ano e por sentido de pista - Autopista Régis Bittencourt

\begin{tabular}{cccc}
\hline Ano & $\begin{array}{c}\text { Densidade } \\
\text { Pista Norte }\end{array}$ & $\begin{array}{c}\text { Densidade } \\
\text { Pista Sul }\end{array}$ & $\begin{array}{c}\text { Densidade } \\
\text { Geral }\end{array}$ \\
\hline $\mathbf{2 0 0 9}$ & 0,0429 & 0,0451 & 0,0440 \\
\hline $\mathbf{2 0 1 0}$ & 0,0359 & 0,0371 & 0,0365 \\
\hline $\mathbf{2 0 1 1}$ & 0,0343 & 0,0382 & 0,0362 \\
\hline $\mathbf{2 0 1 2}$ & 0,0307 & 0,0363 & 0,0335 \\
\hline $\mathbf{2 0 1 3}$ & 0,0261 & 0,0321 & 0,0290 \\
\hline $\mathbf{2 0 1 4}$ & 0,0273 & 0,0289 & 0,0281 \\
\hline $\mathbf{2 0 1 5}$ & 0,0276 & 0,0296 & 0,0286 \\
\hline $\mathbf{2 0 1 6}$ & 0,0264 & 0,0269 & 0,0267 \\
\hline Média & 0,0310 & 0,0339 & 0,0324 \\
\hline
\end{tabular}

Fonte: Elaborada pelo Autor 
É possível observar que houve um aumento de $9,4 \%$ na densidade total de acidentes entre 2009 e 2011, sendo este fato provavelmente associado à melhoria das condições do pavimento nos primeiros anos de concessão, o que permitiu 0 desenvolvimento de velocidades mais elevadas aumentando consequentemente o risco. A partir de 2011, é notável a redução constante da quantidade de acidentes por ano, devido principalmente a melhorias nas condições de sinalização e implantação de dispositivos para controle de velocidade. A redução observada na densidade de acidentes em 2016 foi de 27,8\% em relação ao ano de 2011. Observa-se também que a densidade de acidentes, avaliada anualmente entre 2009 e 2016, sempre foi maior para a pista sul, que registrou uma densidade média no período aproximadamente $9,5 \%$ superior ao registrado na pista norte.

A Figura 25 ilustra a densidade média de acidentes por mês, para o período compreendido entre março de 2009 e dezembro de 2016. Neste período, maior criticidade foi observada para o mês de dezembro, que registrou uma densidade média de 0,035, enquanto para os outros meses a densidade média foi de 0,032. Este fato pode estar relacionado principalmente ao período de férias Natalinas e Ano Novo.

Os dados obtidos pelos pluviógrafos no período entre 2014 e 2016 são apresentados na Figura 26. Os dados foram agrupados por mês, com o intuito de se verificar quais meses, para cada pluviógrafo, registraram os maiores volume de chuva. 
Figura 25 - Avaliação da densidade de acidentes mensal, no período entre 2009 e 2016

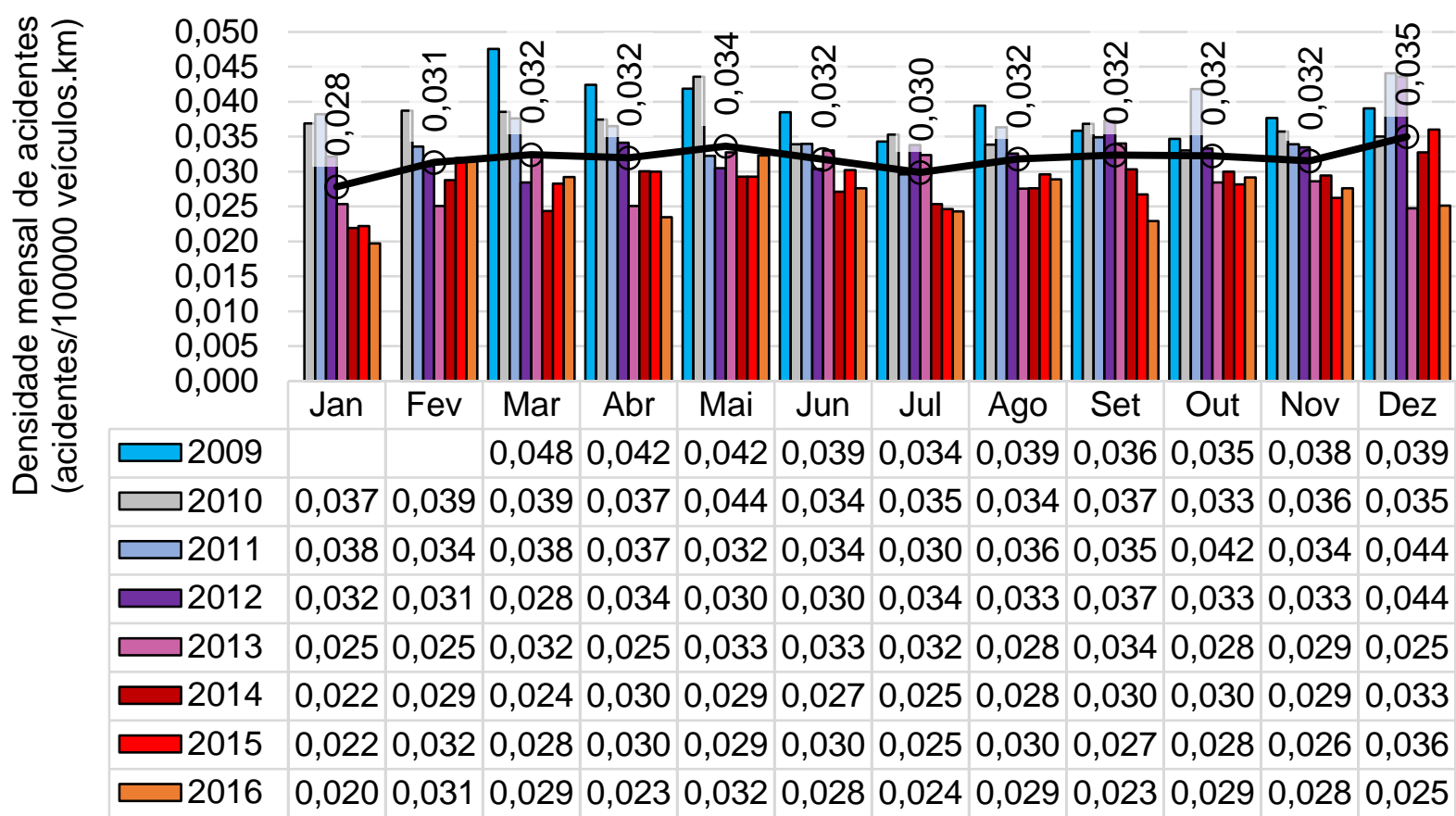

Fonte: Elaborada pelo Autor

Figura 26 - Dados pluviométricos mensais médios entre 2014 e 2016, para os pluviógrafos instalados nas praças de pedágio

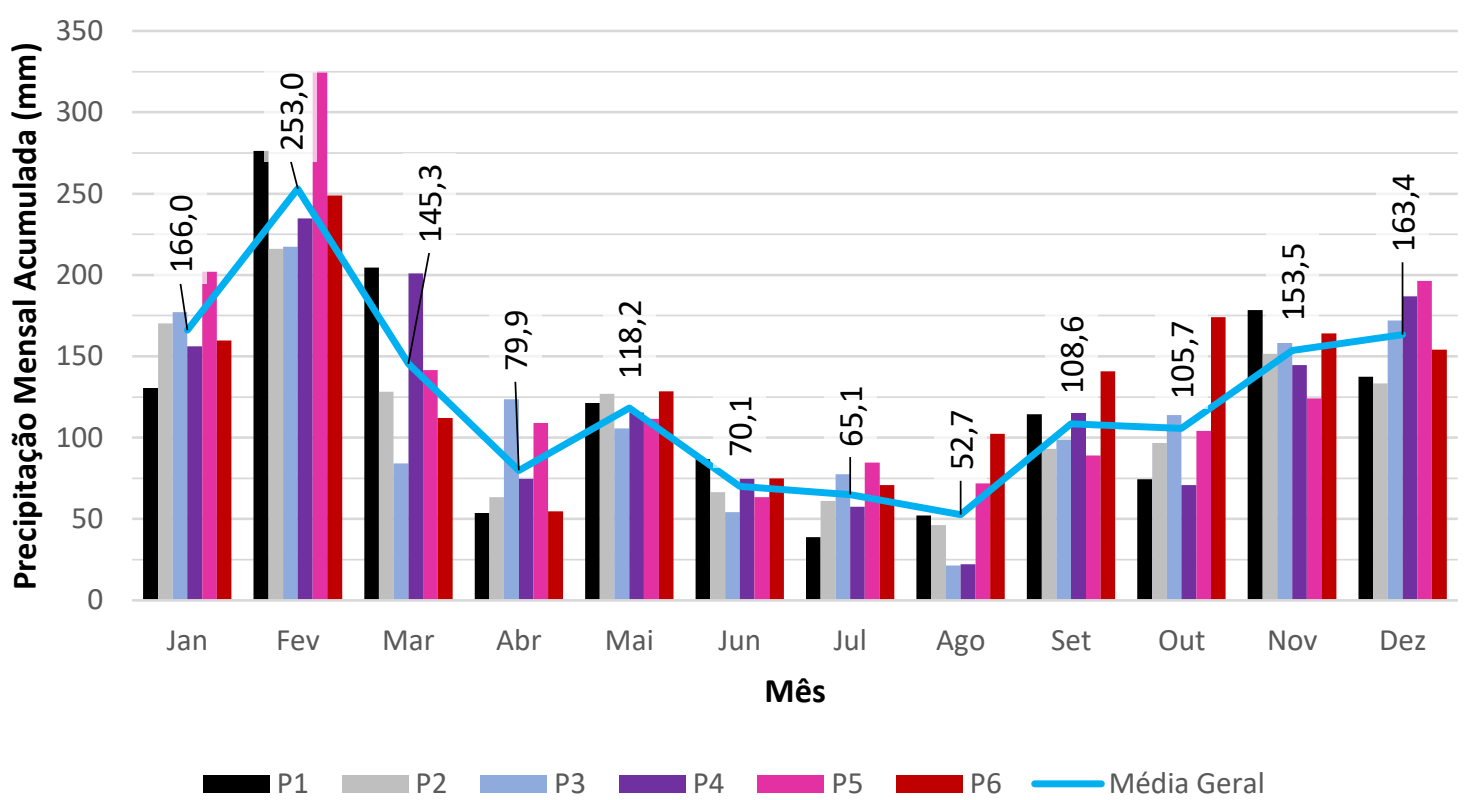

Fonte: Elaborada pelo Autor 
Observa-se que os meses com maior precipitação mensal média são novembro, dezembro, janeiro, fevereiro e março. Uma vez que o mês de dezembro pode ser considerado como um período festivo, pode-se dizer que existe uma maior probabilidade de trânsito de veículos com maior velocidade, e a associação deste fato com o maior volume de chuvas pode justificar a maior densidade de acidentes registrada neste mês.

\subsection{Identificação dos segmentos críticos de ocorrência de acidentes}

Para uma melhor compreensão da distribuição dos segmentos de maior concentração de acidentes, foi plotada em um gráfico a razão entre todos os acidentes registrados no período 2009/2016 e o volume médio de veículos que trafegaram pelos segmentos, em função da localização no eixo da rodovia (Figura 27 e Figura 28). Para melhor visualização gráfica, os acidentes ocorridos entre as delimitações dos marcos quilométricos da rodovia foram acumulados.

Figura 27 - Densidade média de Acidentes Pista NORTE - 2009-2016

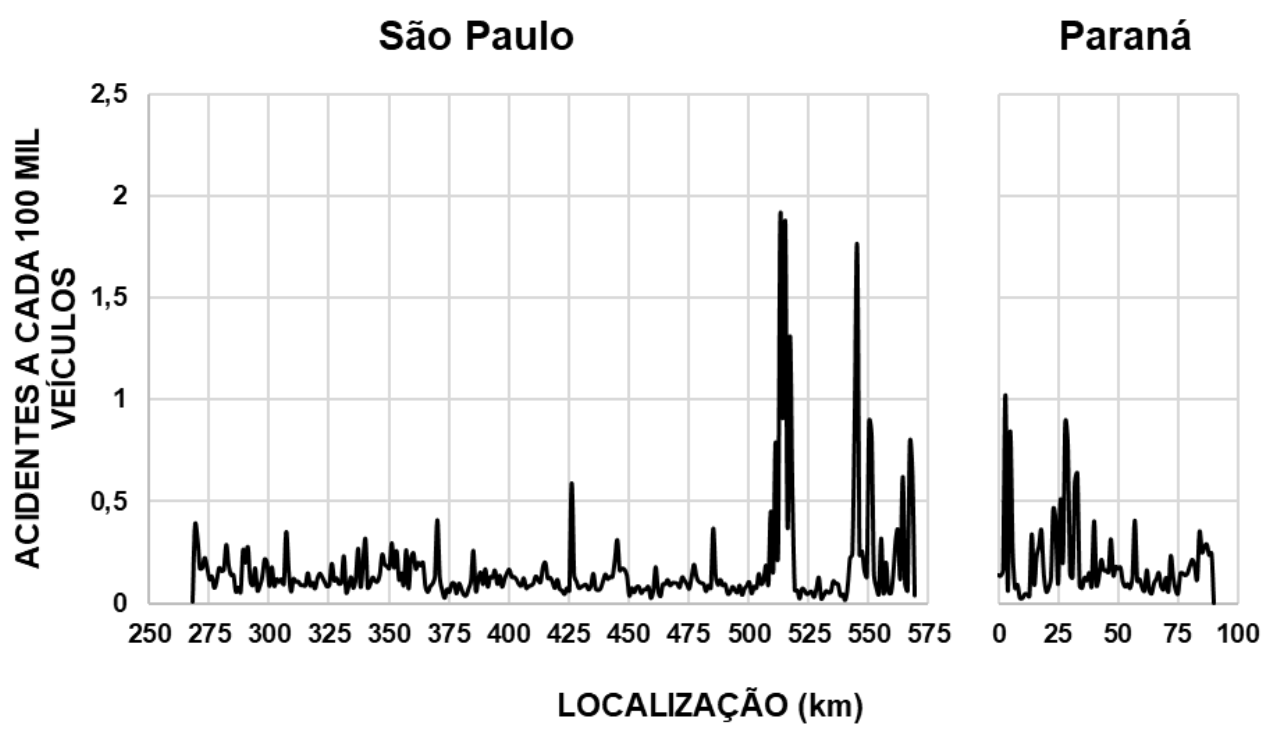

Fonte: Elaborada pelo Autor 
Figura 28 - Densidade média de Acidentes Pista SUL - 2009-2016

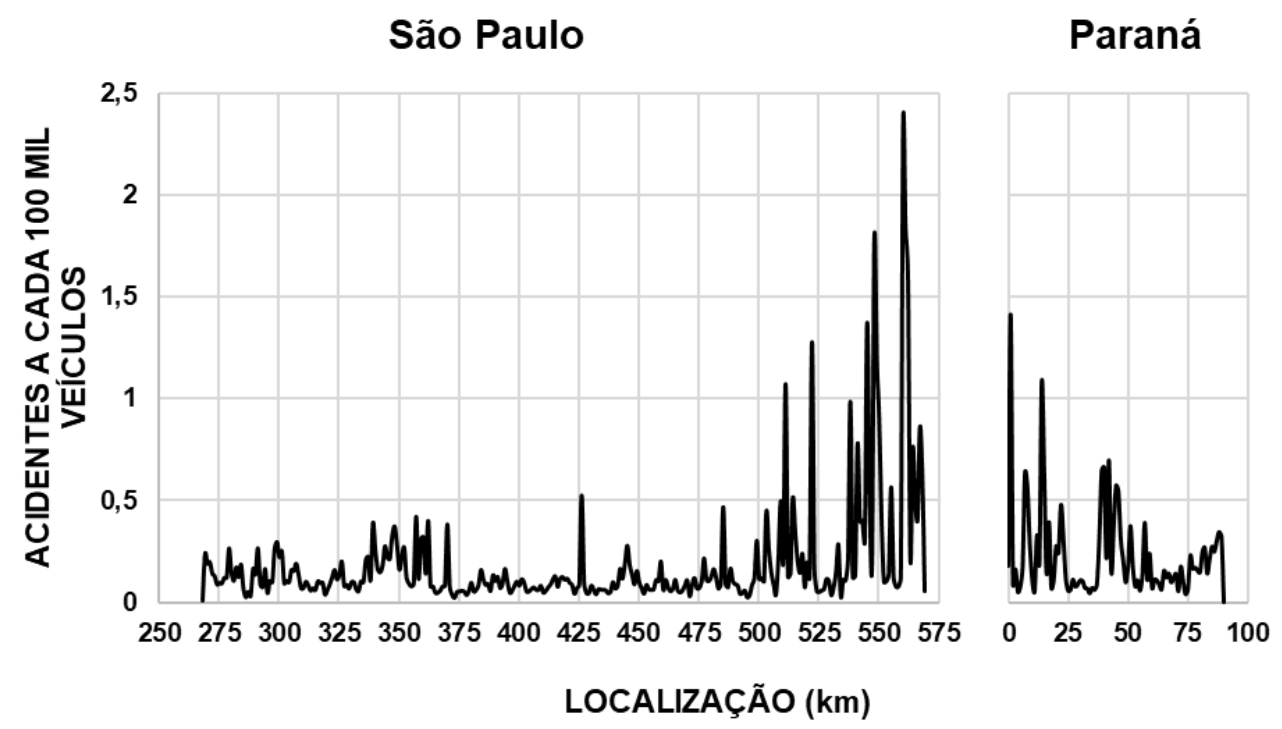

Fonte: Elaborada pelo Autor

A Tabela 10 apresenta os 10 locais com maior densidade de acidentes (acidentes/100 mil veículos) registrados entre 2009 e 2016, tanto para a pista norte quanto para a pista sul.

Tabela 10 - Segmentos com elevada densidade de acidentes

\begin{tabular}{ccccc}
\hline \multirow{2}{*}{ Posição } & \multicolumn{2}{c}{ Pista Norte } & \multicolumn{2}{c}{ Pista Sul } \\
\cline { 2 - 5 } & Densidade $\begin{array}{c}\text { Localização } \\
(\mathbf{k m})\end{array}$ & Densidade & $\begin{array}{c}\text { Localização } \\
\mathbf{( k m})\end{array}$ \\
\hline $\mathbf{1}$ & 1,92 & $513 \mathrm{SP}$ & 2,35 & $560 \mathrm{SP}$ \\
\hline $\mathbf{2}$ & 1,88 & $515 \mathrm{SP}$ & 1,83 & $561 \mathrm{SP}$ \\
\hline $\mathbf{3}$ & 1,76 & $545 \mathrm{SP}$ & 1,79 & $548 \mathrm{SP}$ \\
\hline $\mathbf{4}$ & 1,31 & $517 \mathrm{SP}$ & 1,61 & $562 \mathrm{SP}$ \\
\hline $\mathbf{5}$ & 1,02 & $3 \mathrm{PR}$ & 1,42 & $1 \mathrm{PR}$ \\
\hline $\mathbf{6}$ & 0,93 & $544 \mathrm{SP}$ & 1,37 & $545 \mathrm{SP}$ \\
\hline $\mathbf{7}$ & 0,91 & $514 \mathrm{SP}$ & 1,28 & $522 \mathrm{SP}$ \\
\hline $\mathbf{8}$ & 0,90 & $550 \mathrm{SP}$ & 1,19 & $549 \mathrm{SP}$ \\
\hline $\mathbf{9}$ & 0,89 & $28 \mathrm{PR}$ & 1,09 & $14 \mathrm{PR}$ \\
\hline $\mathbf{1 0}$ & 0,84 & $5 \mathrm{PR}$ & 1,07 & $511 \mathrm{SP}$ \\
\hline
\end{tabular}

Fonte: Elaborada pelo Autor 
Um grande desafio para os profissionais de engenharia rodoviária é delimitar com a máxima precisão possível os segmentos problemáticos antes de abordar as prováveis causas e possíveis soluções para redução da ocorrência dos acidentes.

Uma vez que os veículos geralmente desenvolvem altas velocidades em trechos rodoviários (percorrendo facilmente trechos de vinte metros de extensão, ou mais, em menos de um segundo), e como diversos fatores podem ocasionar ou facilitar a ocorrência de acidentes, as técnicas convencionais, como plotar o número de acidentes relacionados a um local pontual (estimado) de sua ocorrência, podem não fornecer uma imagem clara e precisa dos locais de maior criticidade. Desta forma, uma maneira mais precisa para identificação dos segmentos passíveis de intervenções é através da utilização de técnicas estatísticas espaciais (KHAN; QIN; NOYCE, 2008).

O Estimador de Densidade Kernel (EDK) é um dos métodos mais comuns e bem estabelecidos para identificação de padrões espaciais (PLUG; XIA; CAULFIELD, 2011). No que diz respeito à análise de segurança viária, o EDK é utilizado para calcular a densidade de acidentes em uma região em torno de cada acidente individual, fornecendo como resultado imagens com os pixels coloridos a depender da intensidade de criticidade de cada ponto. Desta maneira, é uma ferramenta bastante útil para visualização, pois áreas de alta criticidade são facilmente identificadas (PLUG; XIA; CAULFIELD, 2011).

O EDK realiza uma contagem de todos os acidentes ocorridos dentro de uma determinada área de influência, de raio $\mathrm{T}$, e realiza a ponderação destes eventos pela distância de cada um em relação ao ponto de interesse (hi), ou seja, a distância entre o ponto em que se deseja calcular a função (S) e o evento observado (Si) (Figura 29) (CARVALHO e CÂMARA, 2004).

Figura 29 - Estimador de Densidade Kernel (EDK)

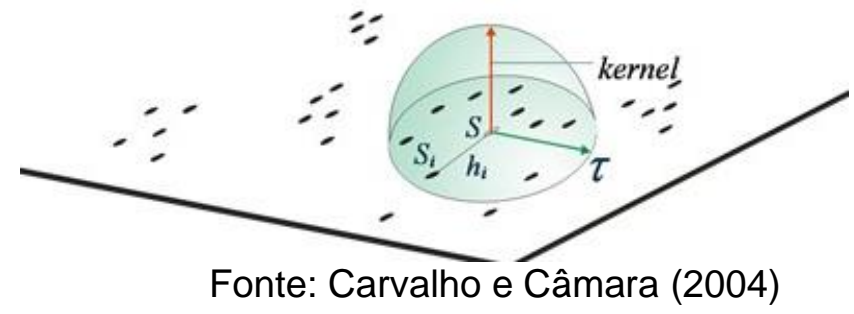


A equação 10 apresenta a fórmula matemática utilizada para cálculo da densidade.

$$
\hat{\lambda}_{\tau}(s)=\sum_{i=1}^{n} \frac{1}{\tau^{2}} I\left(\frac{\left(s-s_{i}\right)}{\tau}\right)
$$

Onde:

I = função de distribuição de probabilidades. É escolhida de forma adequada para construir uma superfície contínua sobre os dados;

$T$ = Raio de influência;

$S=$ Ponto de estudo;

$\mathrm{Si}=$ Localizações dos eventos observados;

$\mathrm{n}=$ número de eventos.

Pode-se notar, através da equação 10, que os eventos mais próximos ao centro (ponto de análise "S") possuem maior representatividade, e os eventos mais afastados (“Si”) possuem menor representatividade ao se afastar radialmente do núcleo.

Visando uma melhor delimitação dos segmentos de maior criticidade, todos os acidentes ocorridos no período foram geocodificados e deu-se início à análise espacial das ocorrências em ambiente SIG (ARTERIS, 2019). As análises espaciais foram realizadas com vistas à criação de mapas de densidade, através da utilização do Estimador de Densidade Kernel. A Figura 30 apresenta os mapas gerais elaborados para as pistas Norte e Sul, e as Figura 31 e Figura 32 apresentam de maneira amplificada os segmentos de maior criticidade de acordo com o estimador de densidade utilizado, para as pistas norte e sul, respectivamente. 
Figura 30 - Mapa de densidade Kernel para os acidentes ocorridos na (a) Pista Norte e (b) Pista Sul

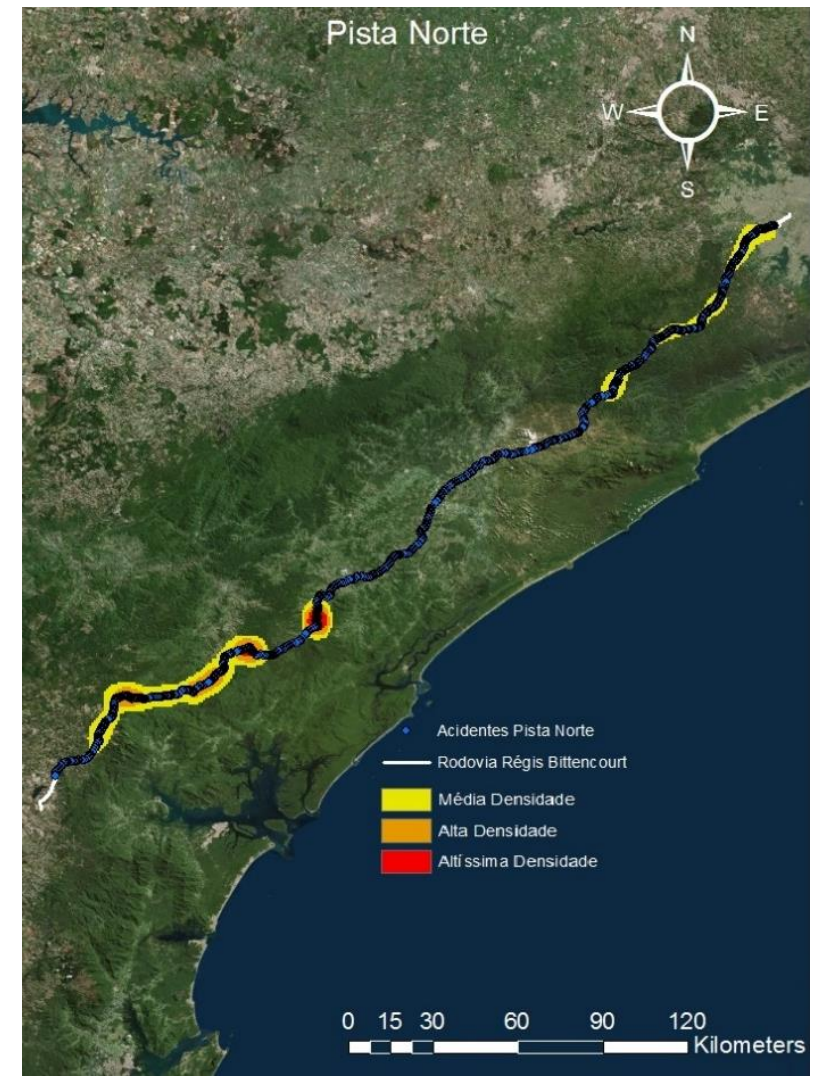

(a)

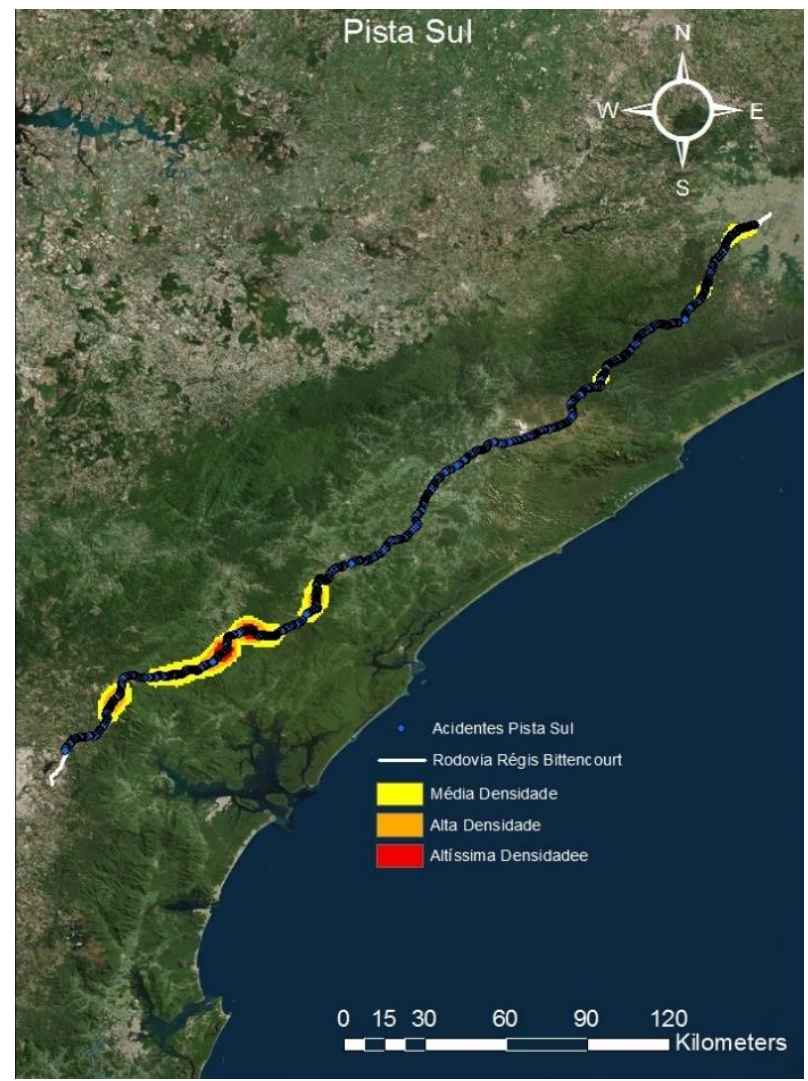

(b)

Fonte: ARTERIS (2019)

Figura 31 - Segmentos de maior densidade de acidentes - Pista Norte

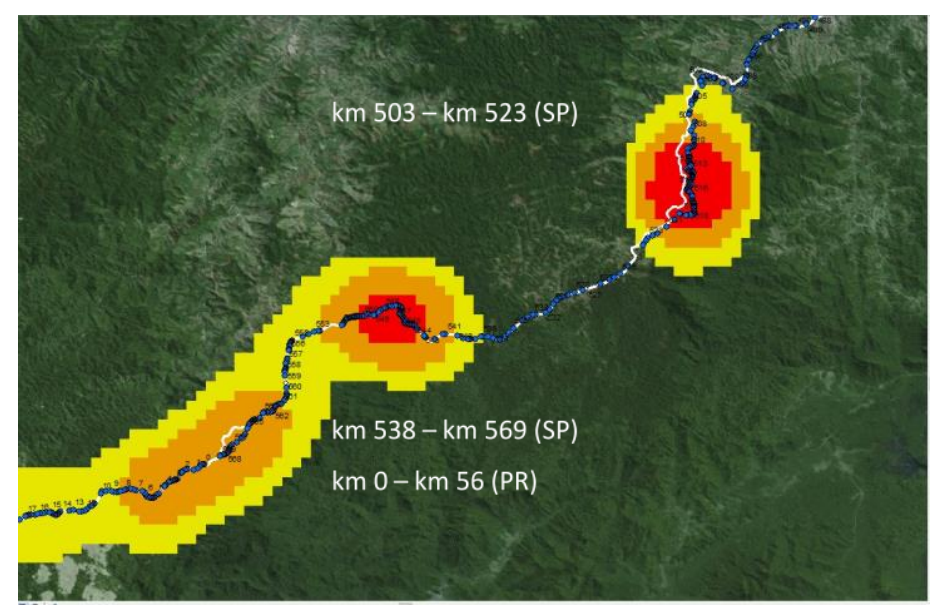

Fonte: ARTERIS (2019) 
Figura 32 - Segmentos de maior densidade de acidentes - Pista Sul

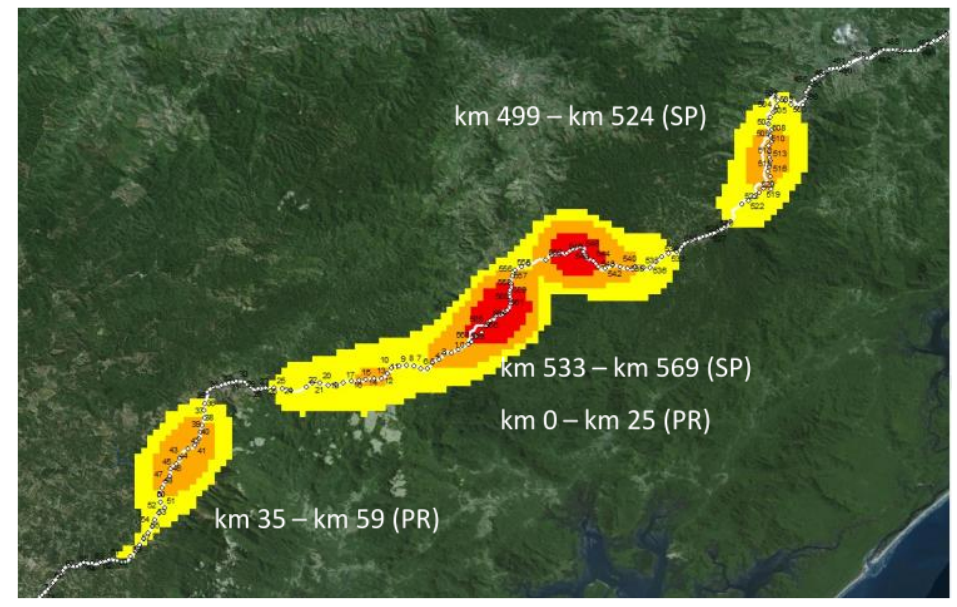

Fonte: ARTERIS (2019)

Através da análise das figuras, é possível inferir que os segmentos de maior criticidade se encontram em locais com características bem específicas. Pode-se observar uma maior criticidade na região mais próxima à São Paulo (região norte da rodovia), que se trata de uma região mais urbanizada, e pode ser observada alta criticidade no trecho mais próximo à Curitiba (região sul da rodovia), onde a grande maioria dos acidentes ocorrem em locais de serra.

É fundamental o conhecimento da causa dos acidentes para que possam ser tomadas medidas efetivas para redução dos acidentes. Sendo assim, os acidentes foram separados por sua causa provável, analisando os boletins de ocorrência fornecidos pela concessionária, e então contabilizados para cada quilômetro da rodovia. A Figura 33 apresenta o somatório de cada tipo de acidente ocorrido entre 2009 e 2016 para cada quilômetro da rodovia, para as pistas norte e sul. 
Figura 33 - Quantidade acumulada de acidentes entre 2009 e 2016, por causa provável, para cada quilometro da rodovia: (a) Pista Norte; (b) Pista Sul

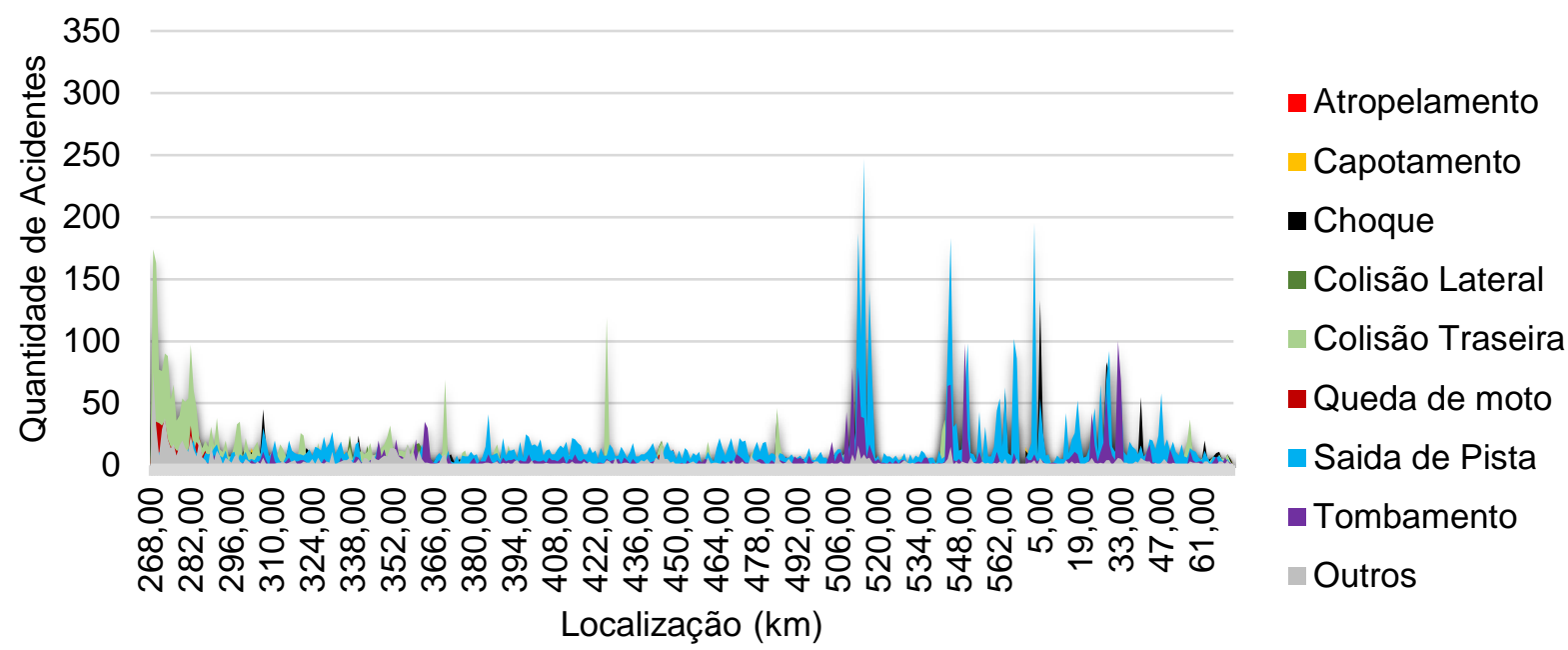

(a)

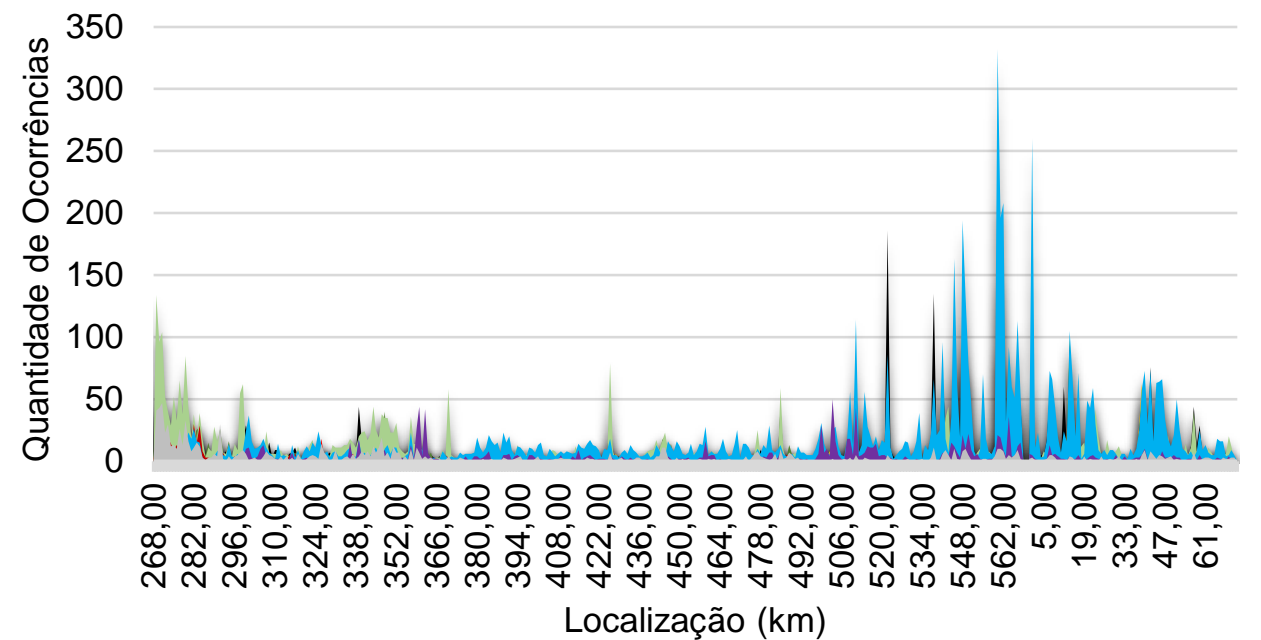

- Atropelamento

- Capotamento

- Choque

- Colisão Lateral

- Colisão Traseira

- Queda de moto

- Saida de Pista

- Tombamento

-Outros

(b)

Fonte: Elaborada pelo Autor

Nota-se que, no segmento da rodovia mais próximo à cidade de São Paulo (quilômetro 268), foram registradas mais ocorrências do tipo Colisão Traseira, tanto para a pista sul, quanto para a pista norte. Este fato se justifica na medida em que se trata de um segmento em uma área mais urbanizada, com bastante variação de velocidade e frenagens repentinas. Pode-se notar também que, entre os quilômetros 500-SP e 35-PR, 
foram registradas mais ocorrências do tipo Saída de Pista. Este fato se justifica na medida em que se trata de um segmento sinuoso, em serra, onde existe uma maior demanda por atrito para que se possa manter o controle direcional dos veículos, além do fato de que a precipitação acumulada nesta região, desde 2014 até o final de 2016, foi a maior registrada em todo segmento da rodovia. Trata-se então de um indicativo da ocorrência de derrapagens por deficiências no atrito entre pneu e pavimento, o que pode ocorrer principalmente em condições chuvosas, com pavimento molhado.

Observa-se que os segmentos de maior criticidade apresentados na Tabela 10 se encontram localizados no segmento mais sinuoso da rodovia, podendo ser aferido também, através da análise da Figura 33, que estes segmentos concentram uma maior quantidade de acidentes identificados como Saída de Pista, demonstrando a relevância deste tipo de ocorrência na criticidade geral da rodovia, e mostrando que a melhoria de atrito pode melhorar consideravelmente as condições de segurança aos usuários.

Foi definida como prioritária a realização das intervenções na pista Sul da rodovia, uma vez que as análises realizadas exibiram uma maior densidade de acidentes durante o período de análise, e também pelo fato de que a pista Norte da rodovia foi objeto de estudo de outro pesquisador (Carvalho, 2019), no mesmo período desta pesquisa.

Após a delineação dos segmentos de maior criticidade através das análises estatísticas e espaciais, foi necessária a realização de uma visita técnica aos locais candidatos a receberem a intervenção de pavimento. Esta visita foi realizada a fim de indicar com maior precisão os locais exatos onde havia a necessidade de intervenção no pavimento. Desta forma, ficou definida a execução dos segmentos experimentais entre os quilômetros 548,780 e 549,420 (trecho experimental 1), e entre os quilômetros 560,000 ao 563,300 (trecho experimental 2).

\subsection{Avaliação geométrica dos segmentos experimentais}

Foi realizado um levantamento topográfico nos segmentos experimentais com o intuito de verificar se as condições geométricas existentes se encontravam em conformidade com as recomendações técnicas para a velocidade regulamentada. Para 
execução deste levantamento, foi utilizada uma Estação Total Eletrônica TOPCON, modelo GTS 246 NW, conforme ilustrado na Figura 34.

Figura 34 - Realização do levantamento topográfico para verificação das condições geométricas dos segmentos experimentais.

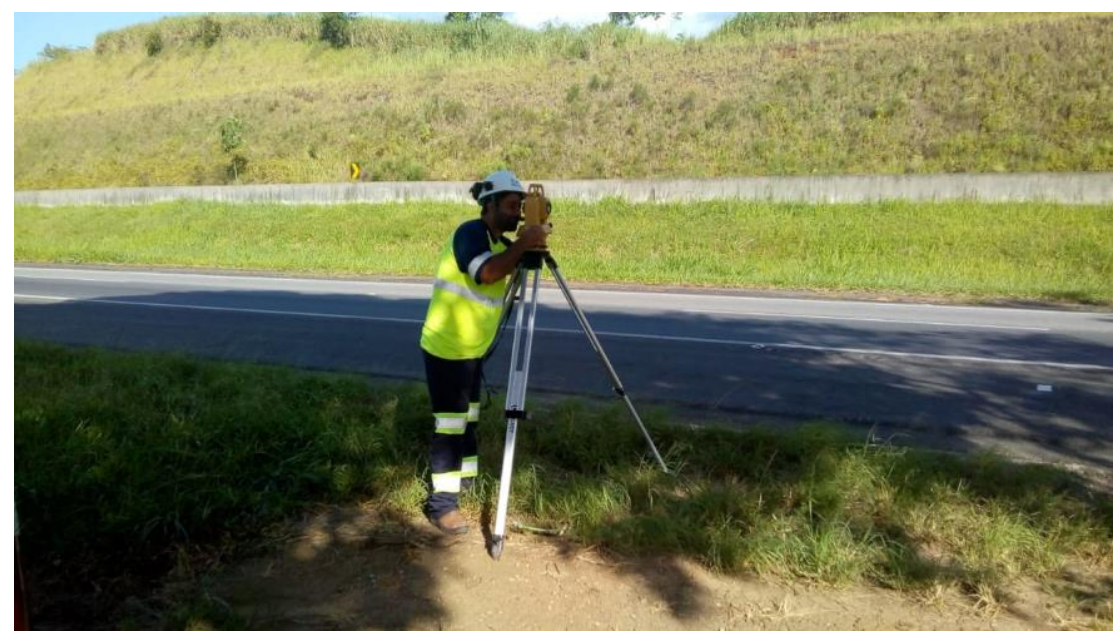

Foto do Autor

Os dados obtidos permitiram realizar a determinação dos raios das curvas circulares existentes nos segmentos selecionados, bem como determinar a declividade longitudinal e a superelevação ao longo do trecho. A Figura 35 e a Figura 36 ilustram os parâmetros geométricos obtidos ao longo dos segmentos, sendo que valores negativos de declividade longitudinal representam trechos em declive, valores de superelevação negativos indicam que o ponto mais baixo da curva circular se encontra no lado direito da pista e valores de raio positivos indicam curvas à direita. 
Figura 35 - (a) Parâmetros geométricos do trecho experimental 1; (b) Vista superior do trecho experimental 1

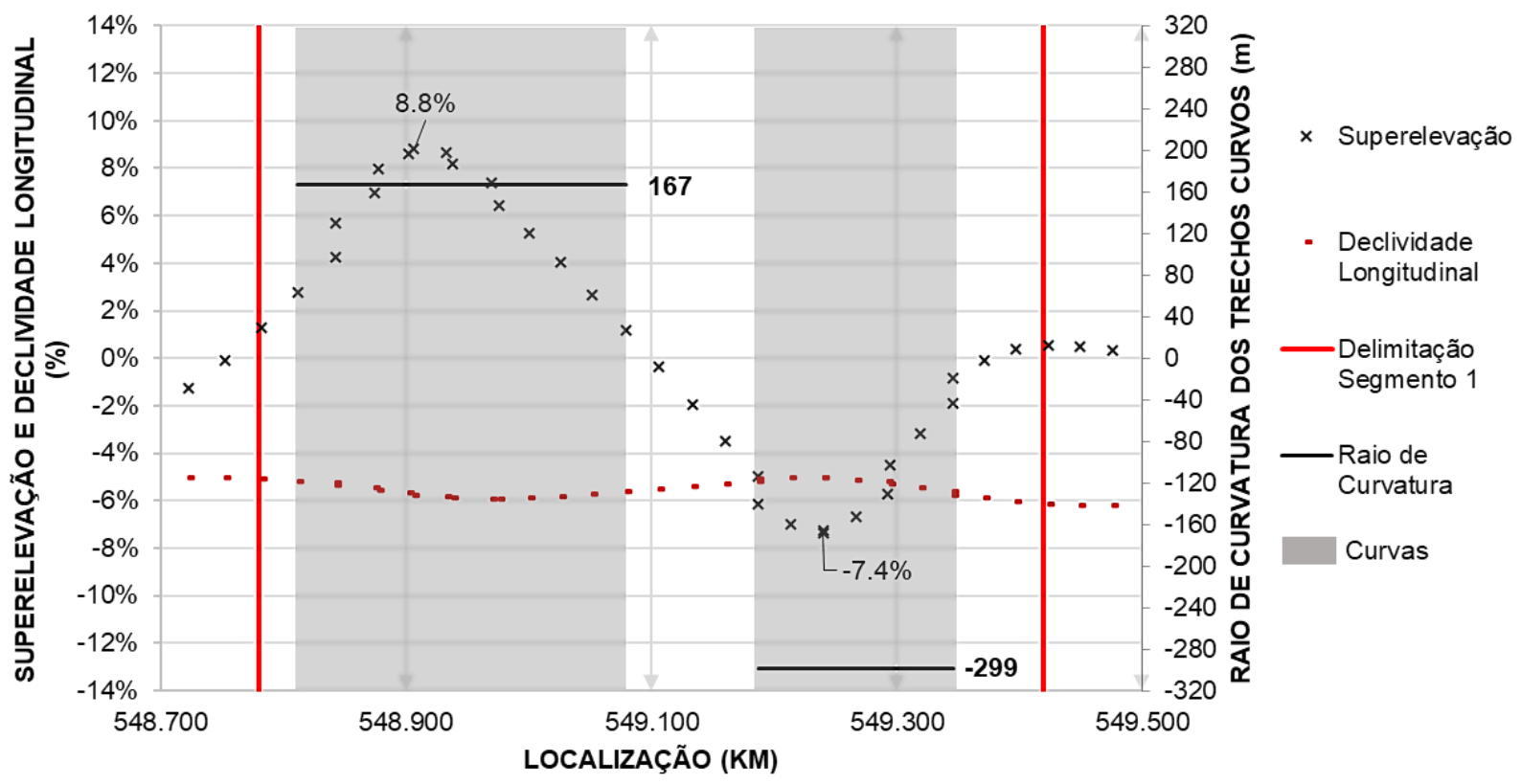

(a)

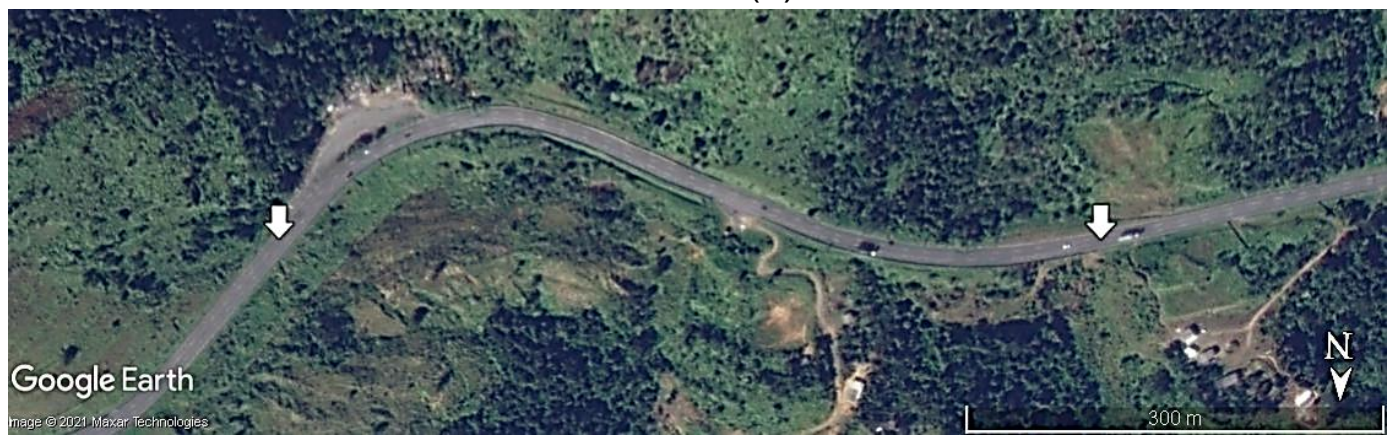

(b)

Fonte: (a) Elaborada pelo Autor,

(b) Elaborada pelo Autor utilizando a ferramenta Google Maps 
Figura 36 - (a) Parâmetros geométricos do trecho experimental 2; (b)Vista superior do trecho experimental 2

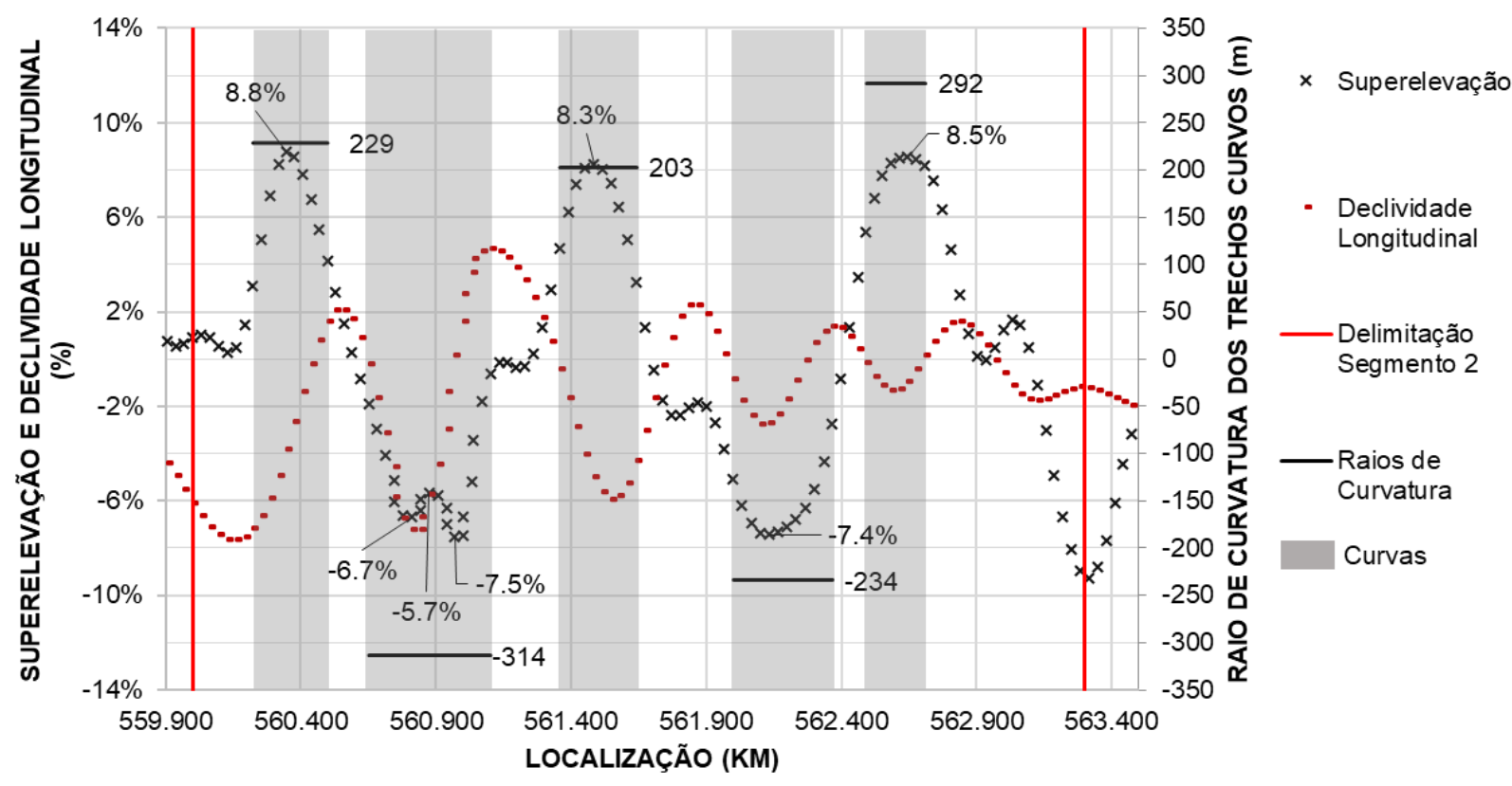

(a)

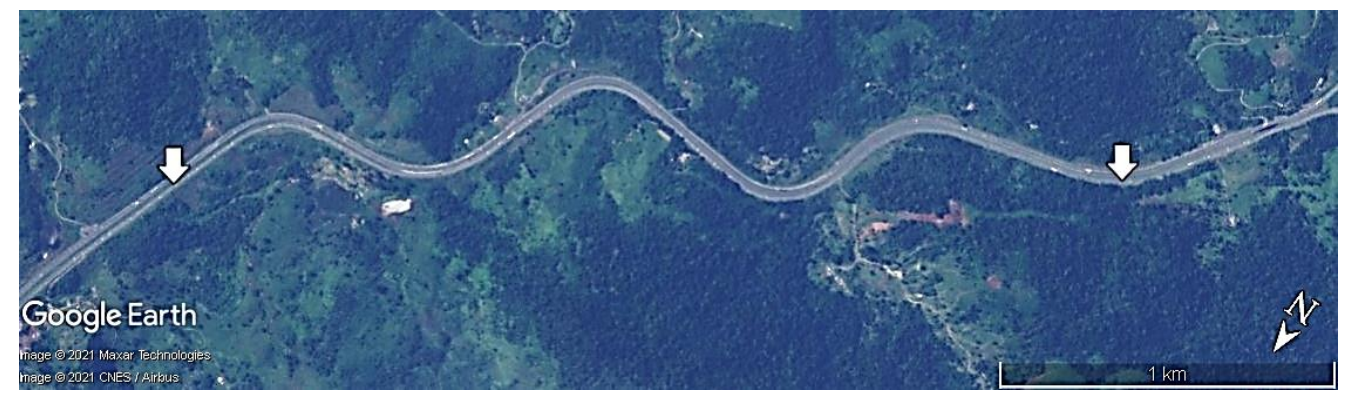

(b)

Fonte: (a) Elaborada pelo Autor,

(b) Elaborada pelo Autor utilizando a ferramenta Google Maps

Em relação ao trecho experimental 1, não se observam deficiências geométricas que possam favorecer a ocorrência de acidentes. O único ponto relevante a ser observado é o fato da existência de uma pequena extensão da rodovia com superelevação igual ou próxima a $0 \%$, sendo este acontecimento natural pela necessidade de transição de superelevação entre as curvas reversas.

Já para o trecho experimental 2, é possível notar que a declividade longitudinal é 
bastante variável, por ser um segmento composto por trechos em aclive e trechos em declive. Por se tratar de uma sequência de 5 curvas reversas, há bastante variação na superelevação ao longo do segmento, o que pode facilitar a formação de lâminas de água de elevada extensão devido à transição de superelevação, contribuindo assim para a ocorrência de hidroplanagem. É possível notar uma leve descontinuidade na evolução da superelevação na segunda curva, entre os quilômetros 560,750 e 561,000. Esta descontinuidade pode ter sido causada por sucessivas campanhas de manutenção, com fresagem e recomposição do pavimento, sem um controle eficiente da espessura de corte ou da espessura da camada compactada. Nota-se uma elevada criticidade para o segmento compreendido entre os quilômetros 561,100 e 561,260, onde a superelevação se encontra muito próxima a $\%$, facilitando a formação de lâminas d'água ao longo de um trecho com 160 metros de extensão, favorecendo a ocorrência de hidroplanagem e consequentemente a perda de controle dos veículos pelos motoristas.

Após a determinação das características geométricas dos segmentos (raios de curvatura e superelevação), e utilizando a equação de regressão (Figura 37) dos valores de fator de atrito para fins de projeto apresentados na

Tabela 5 e comentados no item 2.1.3.2., foi possível determinar, através da utilização da equação 1 (conforme item 2.4.2), a velocidade máxima admissível para cada curva dos trechos experimentais. A Tabela 11 e a Tabela 12 apresentam um resumo dos resultados obtidos.

Figura 37 - Relação entre Velocidade e Fator de Atrito (AASHTO e DNIT)

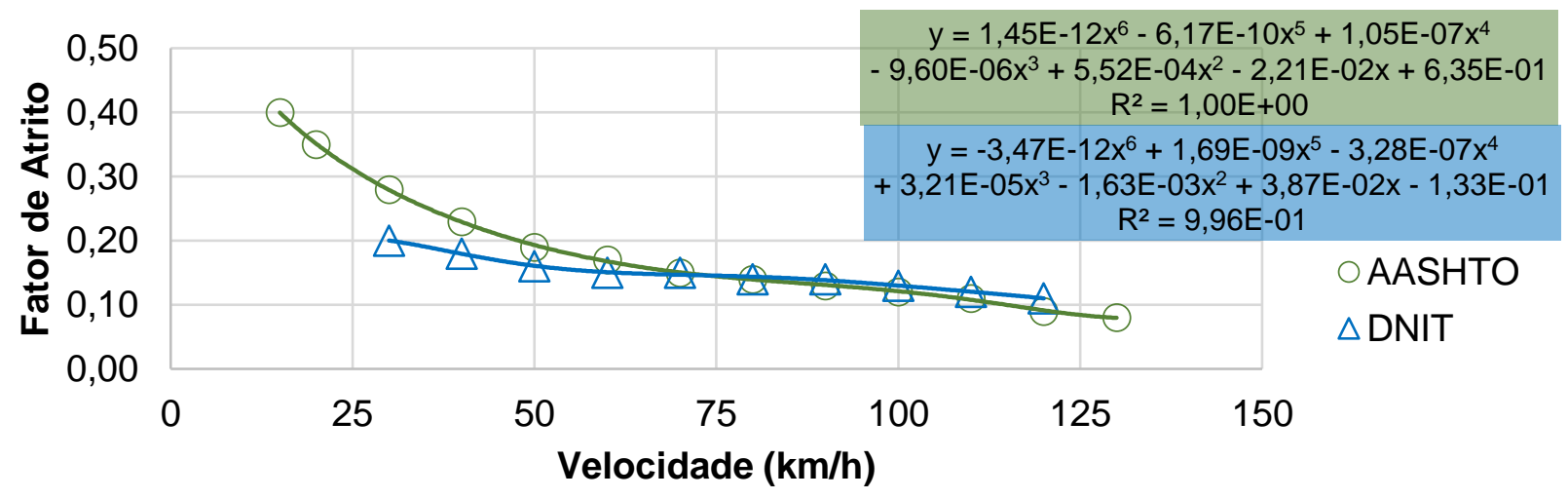

Fonte: Elaborada pelo Autor 
Tabela 11 - Velocidade Máxima Admissível nas Curvas do Trecho Experimental 1

\begin{tabular}{|c|c|c|c|}
\hline \multicolumn{4}{|c|}{ Trecho Experimental 1} \\
\hline \multirow{4}{*}{$\begin{array}{l}\text { Parâmetros } \\
\text { Fixos }\end{array}$} & Local & Curva 1 & Curva 2 \\
\hline & Raio de curvatura & 167 & 299 \\
\hline & Superelevação (e) & $8,8 \%$ & $7,4 \%$ \\
\hline & $\begin{array}{l}\text { Velocidade Máxima } \\
\text { (Regulamentada) }\end{array}$ & \multicolumn{2}{|c|}{$60 \mathrm{~km} / \mathrm{h}$} \\
\hline \multirow{4}{*}{$\begin{array}{l}\text { Parâmetros } \\
\text { Variáveis e } \\
\text { Dependentes } \\
\text { entre si }\end{array}$} & $\begin{array}{l}\text { Coeficiente de Atrito } \\
\text { Lateral - DNIT }\end{array}$ & 0,15 & 0,14 \\
\hline & $\begin{array}{l}\text { Coeficiente de Atrito } \\
\text { Lateral - AASHTO }\end{array}$ & 0,15 & 0,13 \\
\hline & $\begin{array}{l}\text { Velocidade Máxima } \\
\text { Admissível - DNIT }\end{array}$ & 71 & 90 \\
\hline & $\begin{array}{l}\text { Velocidade Máxima } \\
\text { Admissível - AASHTO }\end{array}$ & 71 & 88 \\
\hline
\end{tabular}

Tabela 12 - Velocidade Máxima Admissível nas Curvas do Trecho Experimental 2

\begin{tabular}{|c|c|c|c|c|c|c|}
\hline \multicolumn{7}{|c|}{ Trecho Experimental 2} \\
\hline \multirow{4}{*}{$\begin{array}{l}\text { Parâmetros } \\
\text { Fixos }\end{array}$} & Local & Curva 1 & Curva 2 & Curva 3 & Curva 4 & Curva 5 \\
\hline & Raio de curvatura & 229 & 314 & 203 & 234 & 292 \\
\hline & Superelevação (e) & $8,8 \%$ & $5,7 \%$ & $8,3 \%$ & $7,4 \%$ & $8,5 \%$ \\
\hline & $\begin{array}{l}\text { Velocidade Máxima } \\
\text { (Regulamentada) }\end{array}$ & \multicolumn{5}{|c|}{$60 \mathrm{~km} / \mathrm{h}$} \\
\hline \multirow{4}{*}{$\begin{array}{l}\text { Parâmetros } \\
\text { Variáveis e } \\
\text { Dependentes } \\
\text { entre si }\end{array}$} & $\begin{array}{l}\text { Coeficiente de Atrito } \\
\text { Lateral - DNIT }\end{array}$ & 0,14 & 0,14 & 0,14 & 0,14 & 0,14 \\
\hline & $\begin{array}{l}\text { Coeficiente de Atrito } \\
\text { Lateral - AASHTO }\end{array}$ & 0,14 & 0,13 & 0,14 & 0,14 & 0,13 \\
\hline & $\begin{array}{c}\text { Velocidade Máxima } \\
\text { Admissível - DNIT }\end{array}$ & 82 & 89 & 77 & 80 & 91 \\
\hline & $\begin{array}{l}\text { Velocidade Máxima } \\
\text { Admissível - AASHTO }\end{array}$ & 81 & 87 & 76 & 80 & 90 \\
\hline
\end{tabular}

Elaborada pelo Autor

É possível observar que a velocidade máxima regulamentada para os trechos experimentais (através de controle por radares) é inferior à velocidade máxima admissível para garantia da segurança dos usuários, determinada em função das características geométricas dos segmentos. Sendo assim, pode-se atribuir a elevada criticidade destes 
segmentos a dois fatores principais: (i) a velocidade operacional do segmento é superior à velocidade regulamentada e aferida por radar, pois há elevada probabilidade de os condutores obedecerem aos limites de velocidade impostos apenas no momento de passagem pelos sistemas de controle, e (ii) devido à existência de curvas reversas, pode existir um acúmulo de água na superfície do pavimento, principalmente nos trechos onde a superelevação se torna nula, gerando lâminas d'água de elevada espessura e extensão, favorecendo assim a ocorrência de hidroplanagem em condições chuvosas.

Sendo assim, a implantação de solução de pavimento para aumento de macrotextura e atrito se mostra uma alternativa promissora para redução da quantidade e severidade dos acidentes.

\subsection{Execução do trecho experimental}

Ficou estabelecida como solução mais adequada para o estudo a execução de um Tratamento Superficial Duplo por penetração invertida, aplicado a quente com a utilização de ligante asfáltico modificado por borracha (TSD-AMB), devido à sua elevada textura superficial e ao custo de aplicação relativamente inferior quando comparado com as demais soluções estudadas. O termo penetração invertida é utilizado para descrever os tratamentos superficiais que são executados através da aplicação inicial de uma camada de ligante asfáltico no substrato, para posteriormente se distribuir e comprimir os agregados, de forma que o ligante asfáltico recubra parcialmente os agregados, fixandoos ao substrato. Quando se realiza inicialmente a distribuição e compressão dos agregados, para em seguida se aplicar o ligante asfáltico, que irá penetrar a camada de cima para baixo, utiliza-se o termo penetração direta.

Os Tratamentos Superficiais Duplos por penetração invertida são executados por aplicações sucessivas de camadas de ligantes asfálticos no substrato e camadas de agregados de dimensões semelhantes sobre este ligante asfáltico (Figura 38), o que confere valores elevados de macrotextura. Por ser uma camada de desgaste, com baixa espessura, os tratamentos superficiais não realizam correções de irregularidade, 
replicando esta condição conforme substrato existente. Por este motivo, anteriormente à aplicação deste tipo de solução, devem ser corrigidos todos os defeitos de superfície préexistentes, inclusive possíveis problemas de drenagem que acarretam no fenômeno de bombeamento de finos, o que pode prejudicar o desempenho da camada através do seu desplacamento.

Figura 38 - Representação da camada de TSD

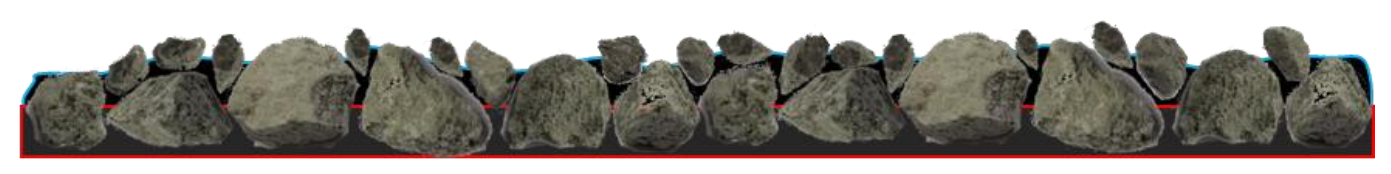

Fonte: Elaborada pelo Autor

Em ambos os trechos experimentais foram utilizados os mesmos materiais e taxas de aplicação. Os materiais foram escolhidos levando em consideração as propriedades necessárias para a garantia da durabilidade da camada asfáltica. Para determinação da taxa ideal de espalhamento do ligante asfáltico e dos agregados foi empregado o método direto, também conhecido como método da caixa dosadora.

A primeira etapa desta metodologia consiste no espalhamento dos agregados horizontalmente em uma caixa com dimensões de $800 \mathrm{~mm} \times 250 \mathrm{~mm} \times 40 \mathrm{~mm}$ (Figura 39), de forma a se obter um mosaico igual ao que se deseja executar em pista (BERNUCCI et al., 2010). Na formulação deste mosaico, especialmente para a primeira camada, devese considerar que a maior dimensão de cada um dos agregados mantenha contato com a superfície da caixa, ou seja, os agregados devem ser mantidos em posição horizontal. Para a segunda camada, pode-se considerar uma porcentagem de sobretaxa, entre $4 \%$ e $20 \%$, visando garantir um bom encaixe entre agregados, considerando também a possível rejeição de alguns agregados e as imperfeições da aplicação (Larsen, 1985).

A segunda etapa consiste na determinação da quantidade ótima de ligante asfáltico a ser utilizada. A dosagem ótima é aquela que permite a não ocorrência de exsudação com uma taxa mínima de rejeito na camada superior do Tratamento Superficial. Diversos são os fatores que devem ser considerados nesta etapa, a saber: 
(i) Tenacidade dos agregados - quanto mais frágil, maior a probabilidade de quebra e redução dos vazios, devendo ser menor a taxa de ligante, (ii) Absorção do agregado altas absorções demandam uma maior quantidade de ligante, (iii) Forma do agregado influenciará nos vazios entre agregados, o que pode ser observado na formulação do mosaico, (iv) Teor de vazios do mosaico, (v) Condições climáticas - quanto maior a temperatura, menor a taxa de ligante, e quanto maior a umidade ambiente, maior deve ser a taxa de ligante, (vi) Volume de tráfego - quanto mais intenso, menor deve ser a taxa de ligante, (vii) Declividade do segmento - para trechos em aclive, deve-se considerar uma menor taxa de ligante, (viii) Condições da superfície - Quanto mais mole for a superfície que receberá o tratamento, maior o agulhamento dos agregados, e menor a quantidade de vazios a ser preenchida com ligante.

Como aproximação preliminar, pode-se estimar uma taxa de ligante entre 6,5\% e $7,5 \%$ em peso do agregado, com uma distribuição média de $40 \%$ desta quantidade para a primeira camada, e $60 \%$ para a segunda camada.

Figura 39 - Caixa Dosadora

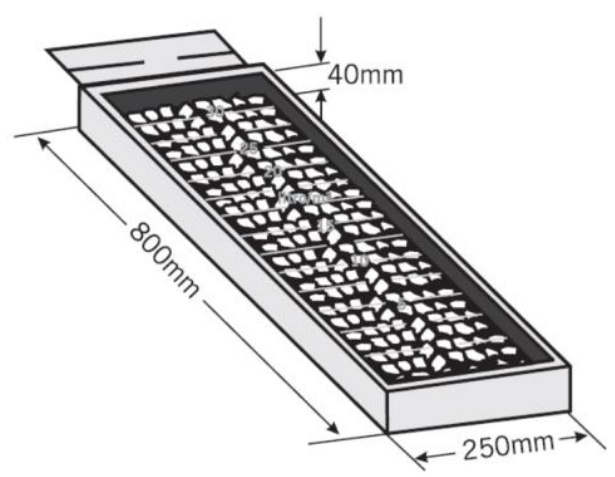

Fonte: Bernucci et al. (2010)

Maiores detalhes deste procedimento podem ser encontrados em Larsen (1985) e Bernucci et al. (2010).

O ligante asfáltico utilizado para a aplicação da solução foi o ECOFLEX TS. Tratase de um material desenvolvido especialmente para utilização em tratamentos superficiais. A escolha pelo ligante asfáltico modificado por borracha se deu em virtude 
das condições críticas dos segmentos, que são compostos por diversas curvas de raio pequeno, onde os esforços dos pneus dos veículos sobre a superfície do pavimento são elevadíssimos, o que pode acelerar o desgaste da camada através do arrancamento de agregados. Neste sentido, entende-se que o ligante asfáltico modificado por borracha pode auxiliar na retenção dos agregados durante a vida útil do pavimento. A Tabela 13 apresenta as características dos materiais utilizados em campo.

Tabela 13 - Análise do ligante asfáltico utilizado nos trechos experimentais

\begin{tabular}{lcccc}
\hline \multirow{2}{*}{ ENSAIO } & \multirow{2}{*}{ NORMA } & ESPECIFICAÇÃo & \multicolumn{2}{c}{ RESULTADOS } \\
\cline { 3 - 5 } & & & TRECHO & TRECHO \\
\hline $\begin{array}{l}\text { Penetração a } 25^{\circ} \mathrm{C}, 100 \mathrm{~g}, 5 \mathrm{~s}, \\
0,1 \mathrm{~mm}\end{array}$ & NBR-6576 & $30-70$ & 46 & $\mathbf{2}$ \\
\hline Ponto Amolecimento, ${ }^{\circ} \mathrm{C}$ & NBR-6560 & Mínimo de 57 & 60 & 60 \\
\hline Recuperação Elástica, $\%$ & NLT-329/91 & Mínimo de 55 & 70 & 70 \\
\hline Ponto de Fulgor, ${ }^{\circ} \mathrm{C}$ & NBR-11341 & Mínimo de 235 & $>240$ & $>240$ \\
\hline Densidade Relativa, $25^{\circ} \mathrm{C}, \mathrm{g} / \mathrm{cm}^{3}$ & NBR-6296 & Anotar & 1,03 & 1,02 \\
\hline $\begin{array}{l}\text { Viscosidade Brookfield a } 175^{\circ} \mathrm{C}, \\
\text { SP 3, 20 RPM, cP }\end{array}$ & NBR-15529 & 2200-4000 & 3750 & 3300 \\
\hline
\end{tabular}

Elaborada pelo Autor

De acordo com Bernucci et al. (2010), são os agregados que conferem a textura e a cor da pista nos tratamentos superficiais, tendo ele como funções principais resistir a fragmentação e a abrasão do tráfego, resistir ao intemperismo, assegurar uma superfície com alta resistência à derrapagem e promover uma drenagem superficial adequada. Para esta pesquisa, foram utilizados agregados provenientes da pedreira Bernamarti (Gnaisse), localizada no município de Colombo-PR. Os agregados utilizados foram enquadrados nos limites estabelecidos pela faixa 5 ( $1^{\underline{a}}$ e $2^{\underline{a}}$ camada) da Especificação de Serviço DEINFRA-SC-ES-P-12/16. A escolha por esta faixa se deu considerando a necessidade de se ter uma boa macrotextura e um bom travamento da camada, buscando maior resistência ao arrancamento devido às condições críticas dos segmentos. Também se considerou que não poderia haver acomodamento excessivo da $2^{2}$ camada sobre a 1aㅗ , para não comprometer a macrotextura. A Tabela 14 apresenta as 
características dos agregados utilizados e a Figura 40 apresenta a granulometria obtida para as duas camadas do tratamento.

Tabela 14 - Características básicas dos agregados, fundamentais para execução do TSD

\begin{tabular}{ccccc}
\hline Ensaio & Unidade & Especificação & Brita 1 & Pedrisco \\
\hline $\begin{array}{c}\text { Massa Específica } \\
\text { Aparente Solta }\end{array}$ & $\left(\mathrm{g} / \mathrm{cm}^{3}\right)$ & - & 1,504 & 1,543 \\
\hline $\begin{array}{c}\text { Índice de Lamelaridade } \\
\text { (DAER/RS-EL 108/01) }\end{array}$ & $(\%)$ & 30 - máx. & 22,5 & 14,5 \\
\hline $\begin{array}{c}\text { Abrasão “Los Angeles” } \\
\text { (NBR NM 51:2001) }\end{array}$ & $(\%)$ & 40 - máx. & 12,9 & - \\
\hline
\end{tabular}

Elaborada pelo Autor

Figura 40 - Granulometria dos agregados para aplicação na $1^{\mathrm{a}}$ camada (Brita 1) e $2^{\mathrm{a}}$ camada (Pedrisco)

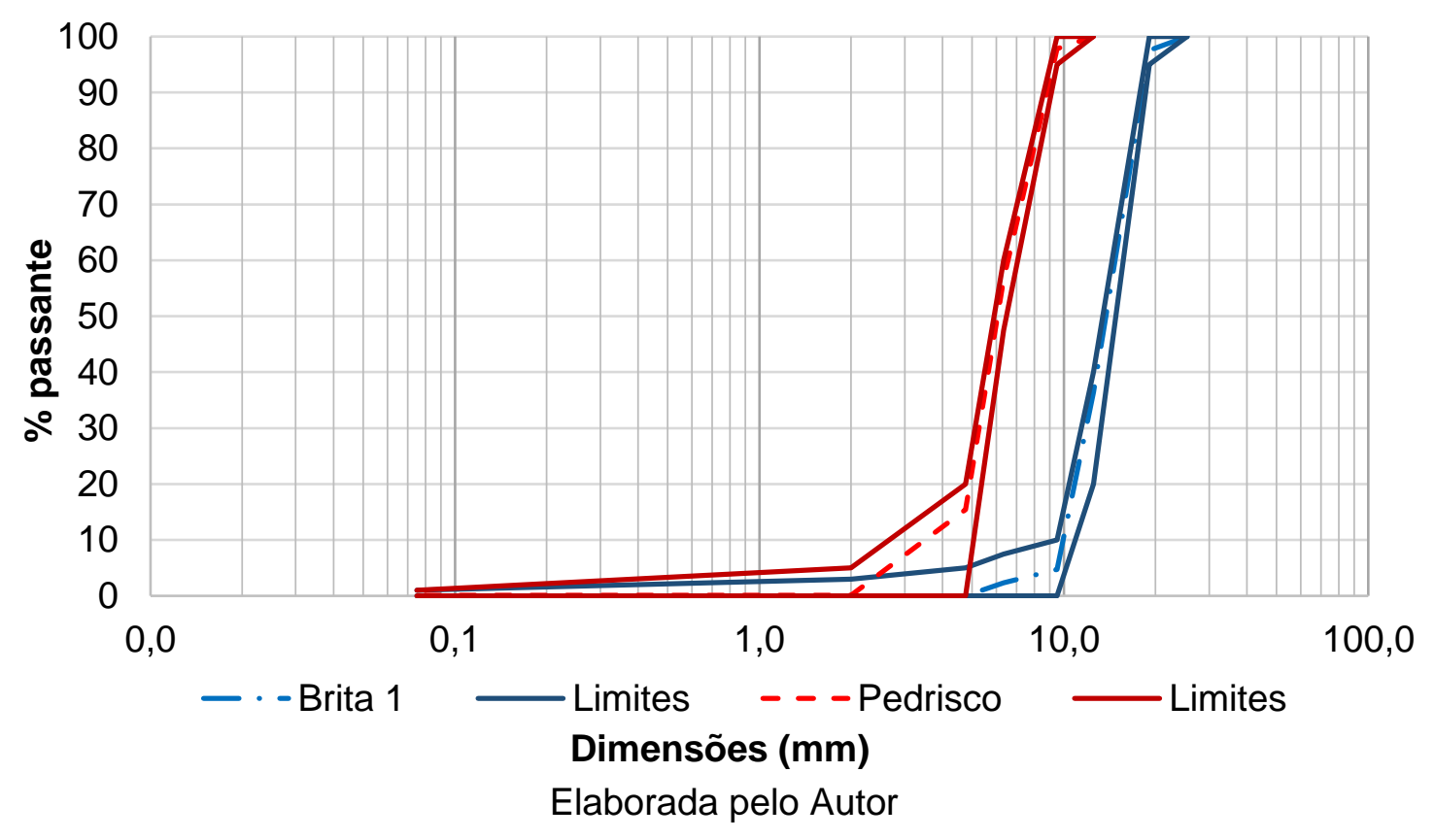

Após a realização do procedimento de dosagem, foi definida a quantidade ideal de cada material para aplicação em campo, objetivando o melhor desempenho possível 
da camada ao longo do tempo. A Tabela 15 apresenta a quantidade ótima definida de cada material para a execução do TSD.

Tabela 15 - Taxas de aplicação dos materiais para execução do TSD

\begin{tabular}{lc}
\hline Taxa da 1 ${ }^{\text {a }}$ aplicação do Ligante Asfáltico & $0,9 \mathrm{Kg} / \mathrm{m}^{2}$ \\
\hline Taxa da 1 ${ }^{\text {a }}$ aplicação de Agregado - Brita 1 & $18,3 \mathrm{Kg} / \mathrm{m}^{2}$ \\
\hline Taxa da 2 ${ }^{\text {a }}$ aplicação do Ligante Asfáltico & $1,0 \mathrm{Kg} / \mathrm{m}^{2}$ \\
\hline Taxa da $2^{\text {a }}$ aplicação de Agregado - Pedrisco & $11,0 \mathrm{Kg} / \mathrm{m}^{2}$ \\
\hline
\end{tabular}

Elaborada pelo Autor

Uma vez confirmado o atendimento de todas as características necessárias para o bom desempenho do serviço pelos materiais, e com a dosagem ideal definida, iniciouse a execução do trecho experimental. Inicialmente, foi realizado o pré envolvimento dos agregados com cimento asfáltico de petróleo convencional de classificação 50/70. Este pré envolvimento deve ser sempre realizado em usina de concreto asfáltico usinado a quente, onde se utiliza uma taxa de ligante entre $0,3 \%$ e $0,9 \%$ em massa de agregado, com a finalidade de reduzir a influência do material pulverulento presente no agregado, de forma a melhorar sua característica de adesividade. Para este serviço, foi utilizada uma usina do tipo drum-mixer, sendo que o teor de ligante asfáltico para realização do pré envolvimento foi de $0,5 \%$ em massa, para a Brita 1 , e de $0,8 \%$, em massa, para o pedrisco, devido às características dos agregados utilizados. A Figura 41 ilustra os agregados após a realização do pré envolvimento. 
Figura 41 - Pré envolvimento realizado nos agregados (a) Brita 1 e (b) Pedrisco

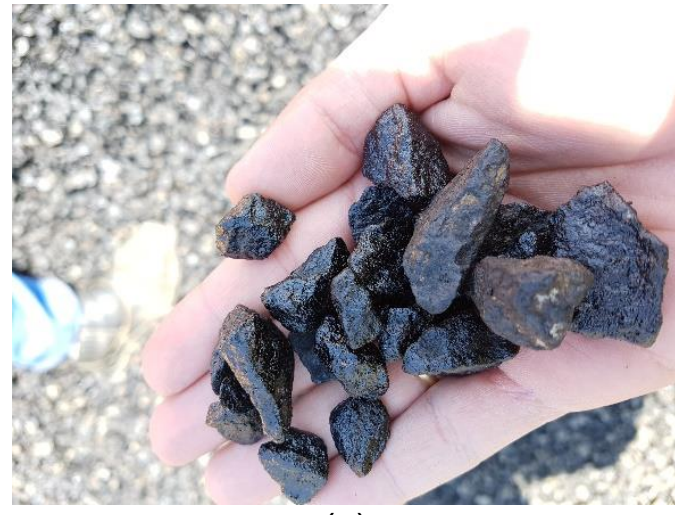

(a)

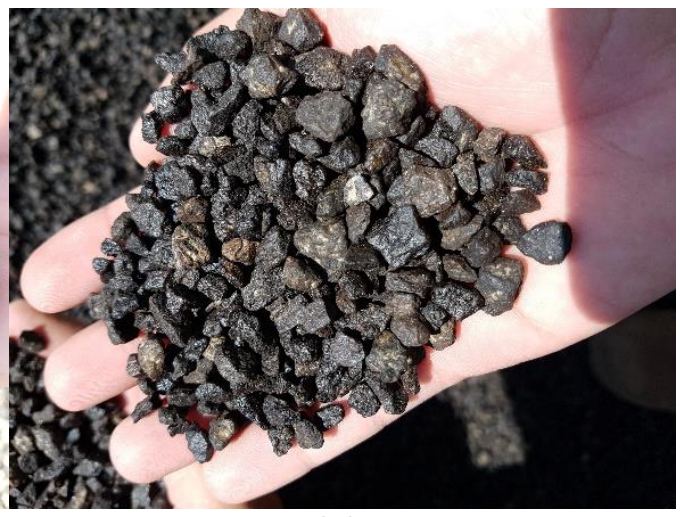

(b)

Fotos do Autor

Após a realização do pré envolvimento, foi realizada a calibração dos equipamentos no canteiro de obras, para garantia da aplicação dos materiais nas taxas corretas definidas anteriormente. A calibração foi realizada através da aplicação dos materiais separadamente sobre uma lona de área conhecida (Figura 42) e posterior pesagem e cálculo da taxa de material por metro quadrado.

Figura 42 - Calibração das taxas de aplicação no canteiro de obras

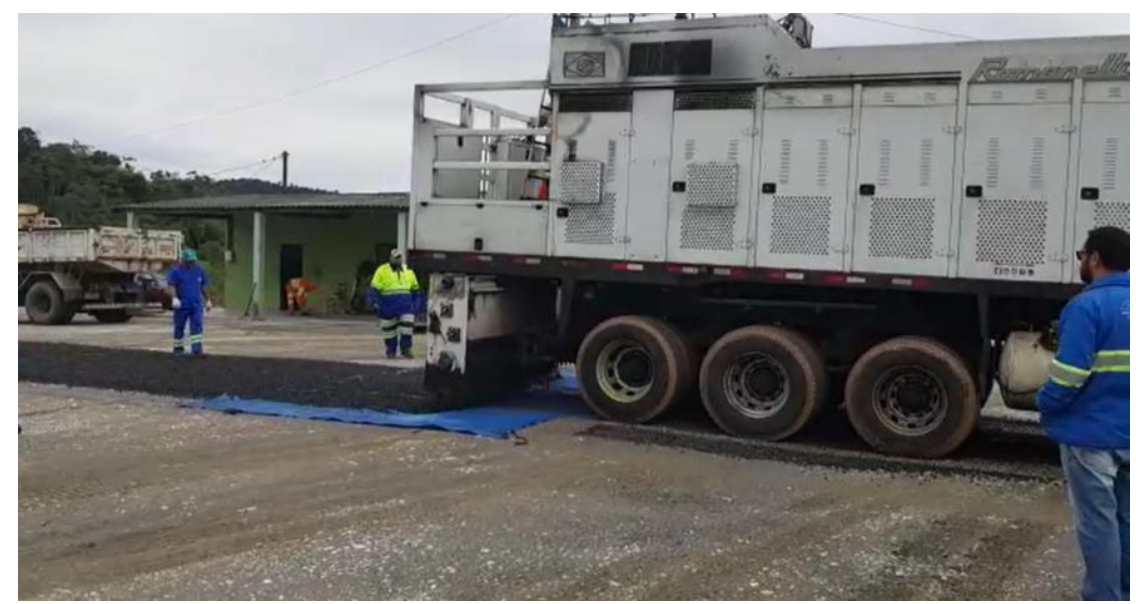

Foto do Autor 
Uma vez ajustada a vazão dos materiais, o equipamento multi-distribuidor de asfalto e agregados utilizado é capaz de garantir a correta taxa de aplicação realizando correções constantes de acordo com a velocidade de operação. Caso exista uma variação considerável de velocidade do equipamento durante a execução dos serviços, a vazão de materiais é automaticamente interrompida e deve-se reiniciar os trabalhos, o que evita que ocorram falhas de aplicação da camada asfáltica.

Também foi realizada a calibração da altura da barra espargidora de ligante asfáltico. De acordo com o Asphalt Institute (2010), a altura da barra espargidora sobre a superfície do pavimento deve ser ajustada de forma a garantir a uniformidade do espalhamento do asfalto. Barras espargidoras posicionadas com altura insuficiente em relação à superfície do pavimento podem causar falhas de recobrimento, enquanto barras posicionadas com altura excessiva em relação à superfície do pavimento podem sofrer a influência de ventos com consequente distorção do spray pulverizado pelo equipamento. O Asphalt Institute (2010) cita que os melhores resultados são obtidos quando ocorre o recobrimento triplo do spray pulverizado. Caso não seja possível calibrar o equipamento para execução de um recobrimento triplo, devido à distância entre os bicos da barra espargidora (superior a $150 \mathrm{~mm}$ ) em alguns equipamentos, pode-se ajustar a altura para execução de um recobrimento duplo, sem prejuízos à execução dos serviços. A Figura 43 ilustra a sobreposição dos sprays de acordo com a altura da barra espargidora. 
Figura 43 - Sobreposição dos Sprays e altura da Barra Espargidora

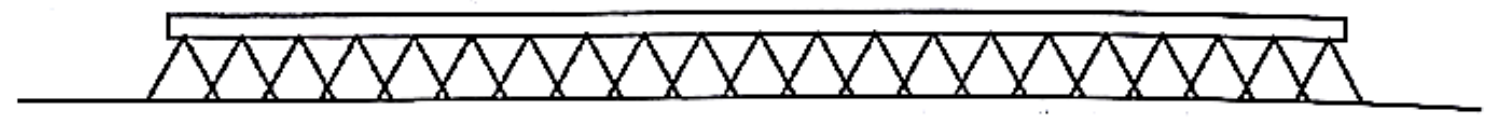

Altura Incorreta da Barra Espargidora

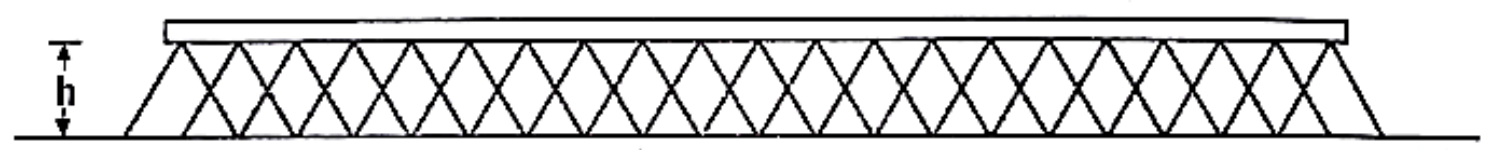

Altura Correta da Barra Espargidora -

Recobrimento Duplo

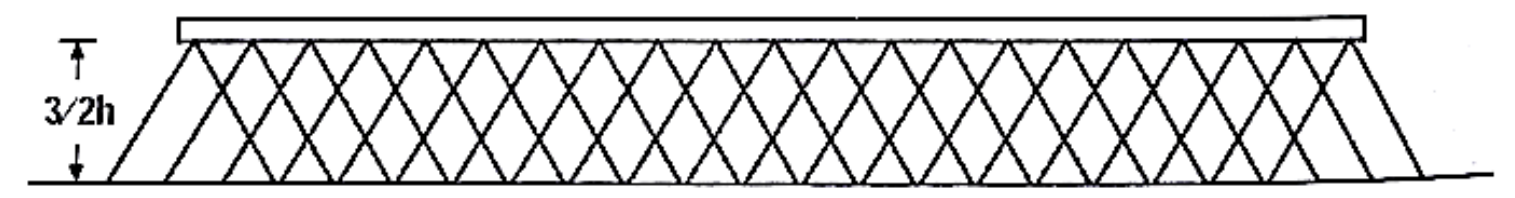

Altura Correta da Barra Espargidora Recobrimento Triplo

Fonte: Adaptado de Asphalt Institute (2010)

Para execução dos serviços, foi possível a calibração da altura da barra para garantia de um recobrimento triplo.

Após a realização da calibração dos equipamentos no canteiro de obras, deu-se início a execução dos trechos experimentais. Inicialmente, é necessário posicionar uma faixa de papel Kraft no início do segmento (Figura 44) para garantia de um bom acabamento da junta transversal. Esta técnica permite que a aplicação dos materiais se inicie sobre o papel, de forma que as taxas de aplicação dos materiais estejam em completo equilíbrio ao atingirem a superfície a ser tratada. O mesmo procedimento deve ser realizado ao final do segmento, de forma a garantir uma perfeita junta transversal. A Figura 45 ilustra o espalhamento dos materiais da primeira camada (ligante asfáltico e Brita 1). 
Figura 44 - Posicionamento do papel Kraft no início do segmento

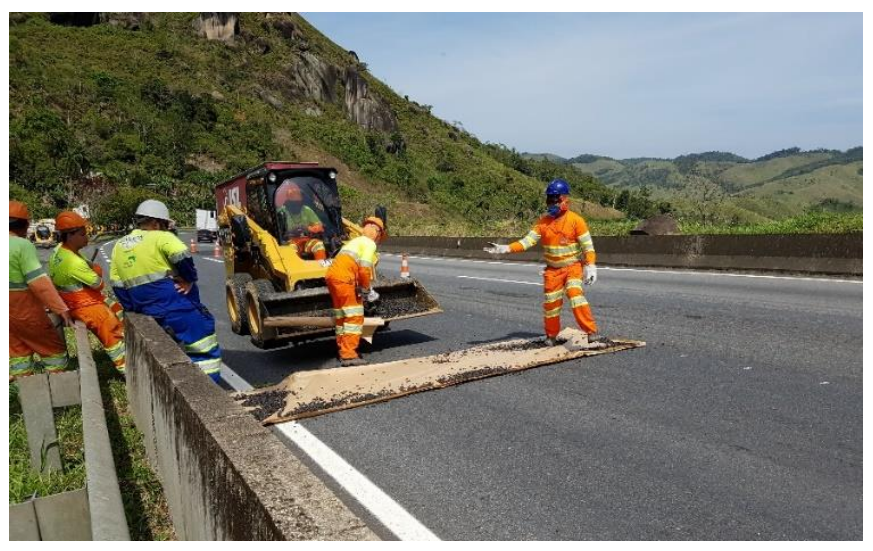

Foto do Autor

Figura 45 - Espalhamento dos materiais da primeira camada do TSD

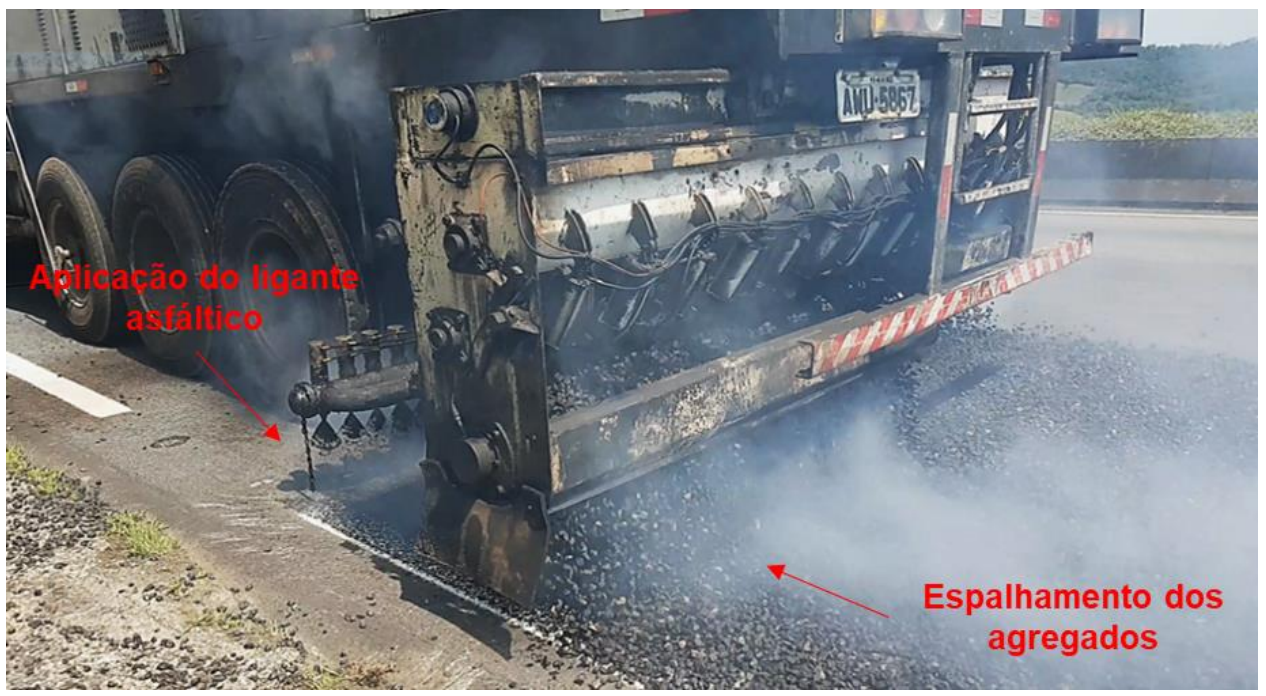

Foto do Autor

Após o espalhamento dos materiais, dá-se início à densificação ou compressão dos agregados. Para compactação da primeira camada devem ser utilizados rolos pneumáticos com pressões de pneu entre 60-90 Psi (ASPHALT INSTITUTE, 2010). Os pneus forçam que o lado de maior dimensão dos agregados seja firmemente comprimido contra o ligante asfáltico aplicado, sem quebrar as partículas. A Figura 46 ilustra 0 processo de compressão sendo executado, bem como a textura obtida para a primeira camada. 
Figura 46 - (a) Compactação da 1르 camada com utilização de rolo pneumático; (b) Textura obtida para a primeira camada (Brita 1)

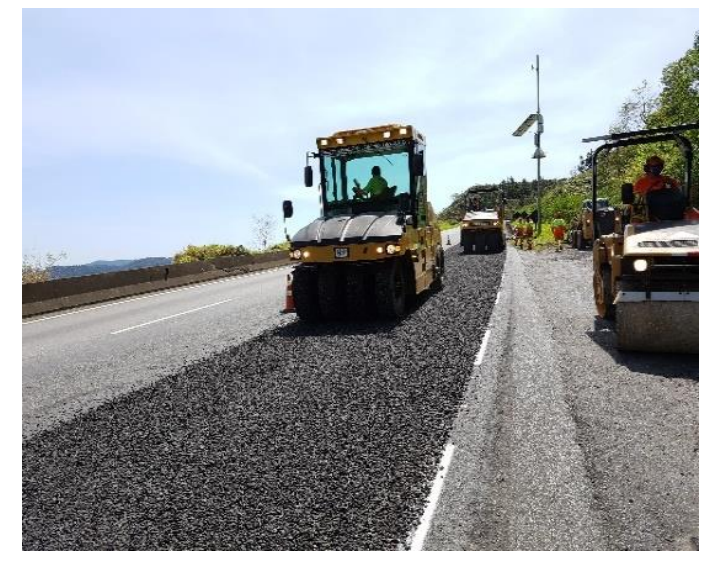

(a)

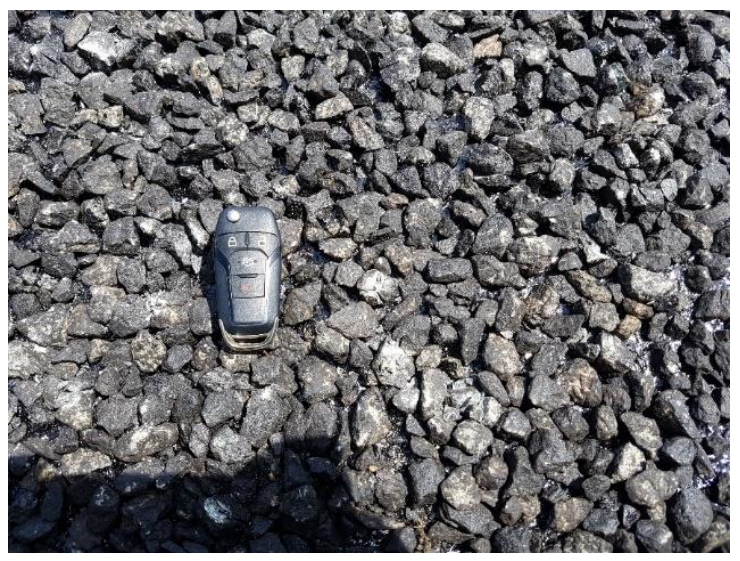

(b)

Foto do Autor

Para execução da segunda camada, com aplicação do pedrisco, a faixa de papel Kraft foi posicionada alguns centímetros antes do início da primeira camada, de forma a evitar a ocorrência de degraus na pista. O espalhamento é então realizado da mesma forma descrita para a primeira camada e, após a conclusão do procedimento de compactação dos materiais, deve ser realizado o resfriamento da camada com espalhamento de água em sua superfície, para que seja possível realizar a limpeza com a remoção dos agregados que não aderiram perfeitamente à camada subjacente. $A$ Figura 47 ilustra o procedimento executado e a textura final obtida. 
Figura 47 - (a) Posicionamento do papel Kraft para início da execução da $2^{a}$ camada, (b) Resfriamento da camada através da aplicação de água, (c) Limpeza da camada finalizada, para remoção de agregados soltos, e (d) Textura final obtida

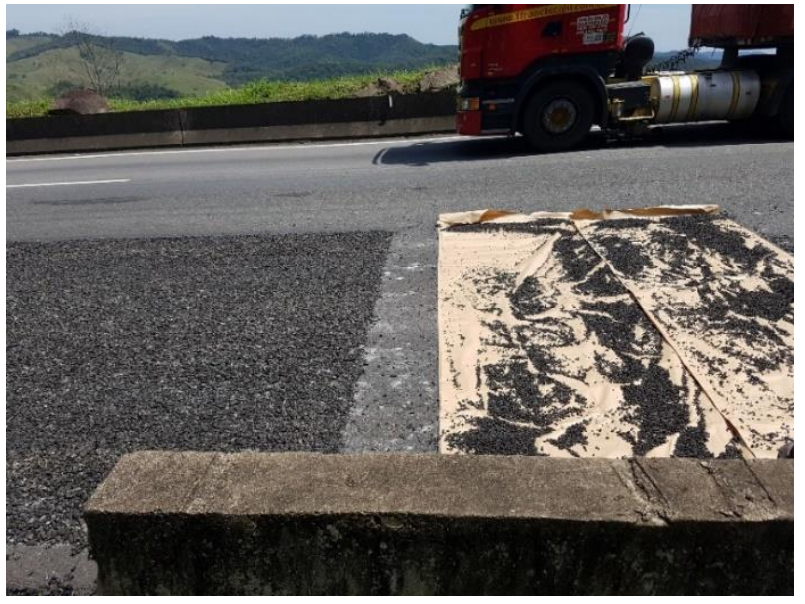

(a)

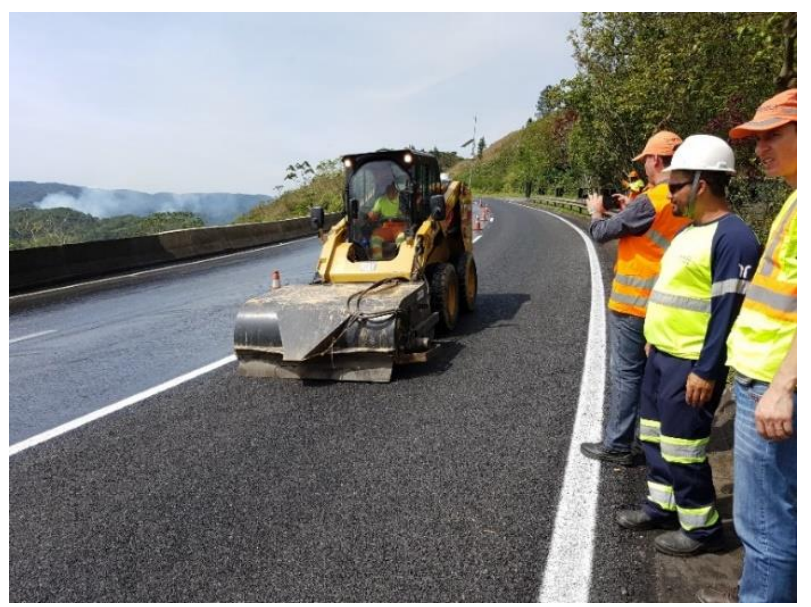

(c)

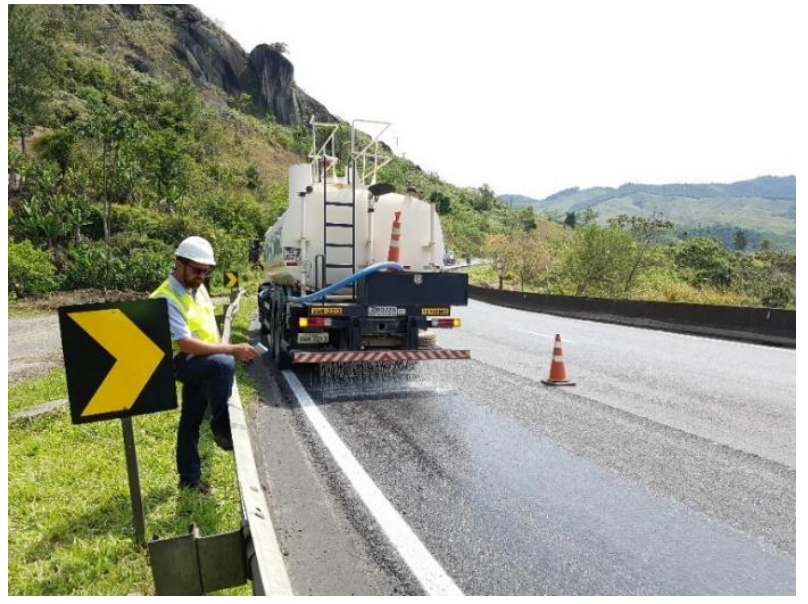

(b)

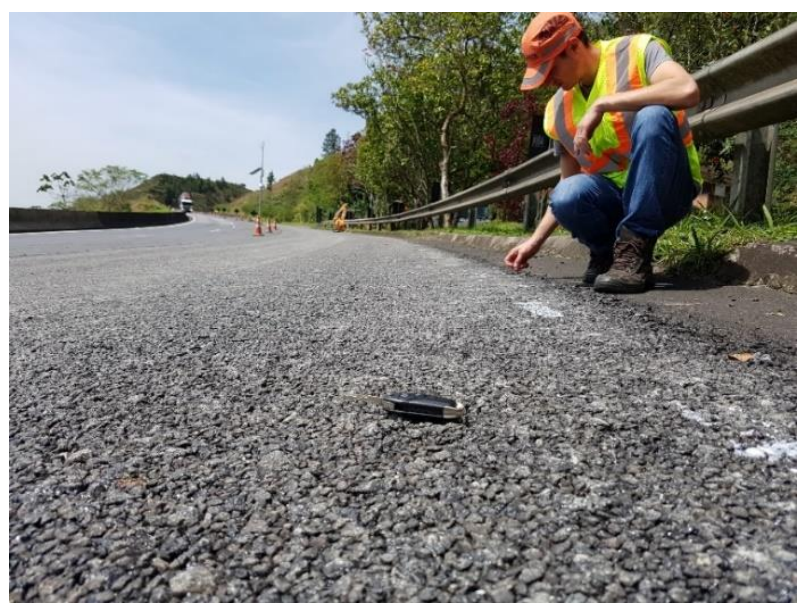

(d)

Fotos do Autor

A Figura 48 ilustra uma comparação entre superfície da camada de TSD-AMB aplicada com uma superfície de concreto betuminoso usinado a quente convencional (de granulometria contínua, bem graduada), quando o pavimento se encontra molhado, e a Figura 49 ilustra o escoamento superficial da água na camada de TSD-AMB, onde é possível observar que os agregados permanecem expostos mesmo na presença de água. 
Figura 48 - Comparação entre as camadas de TSD (faixa da esquerda) e CBUQ (faixa da direita) após derramamento de água na Superfície

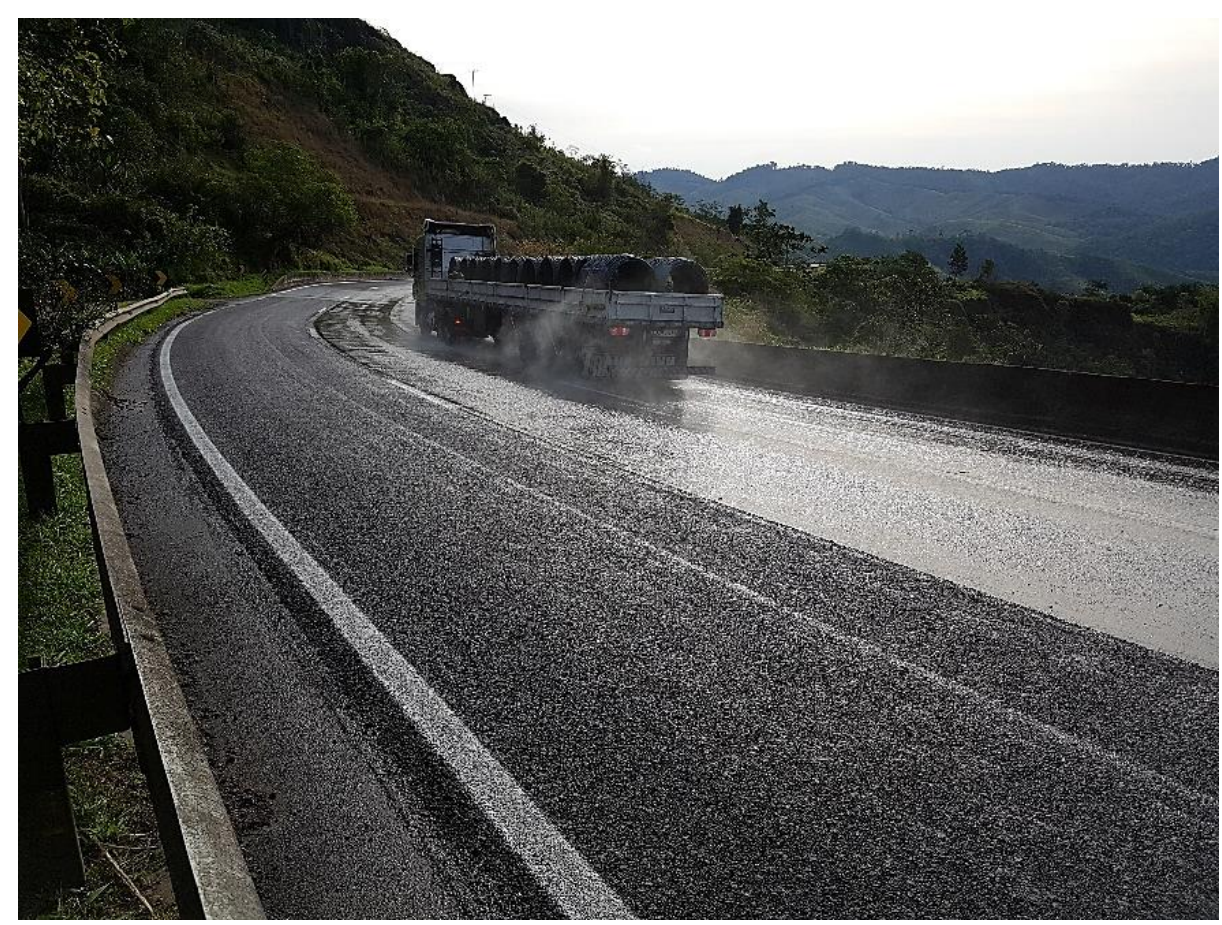

Foto do Autor

Figura 49 - Escoamento superficial da água no TSD com asfalto modificado por borracha executado

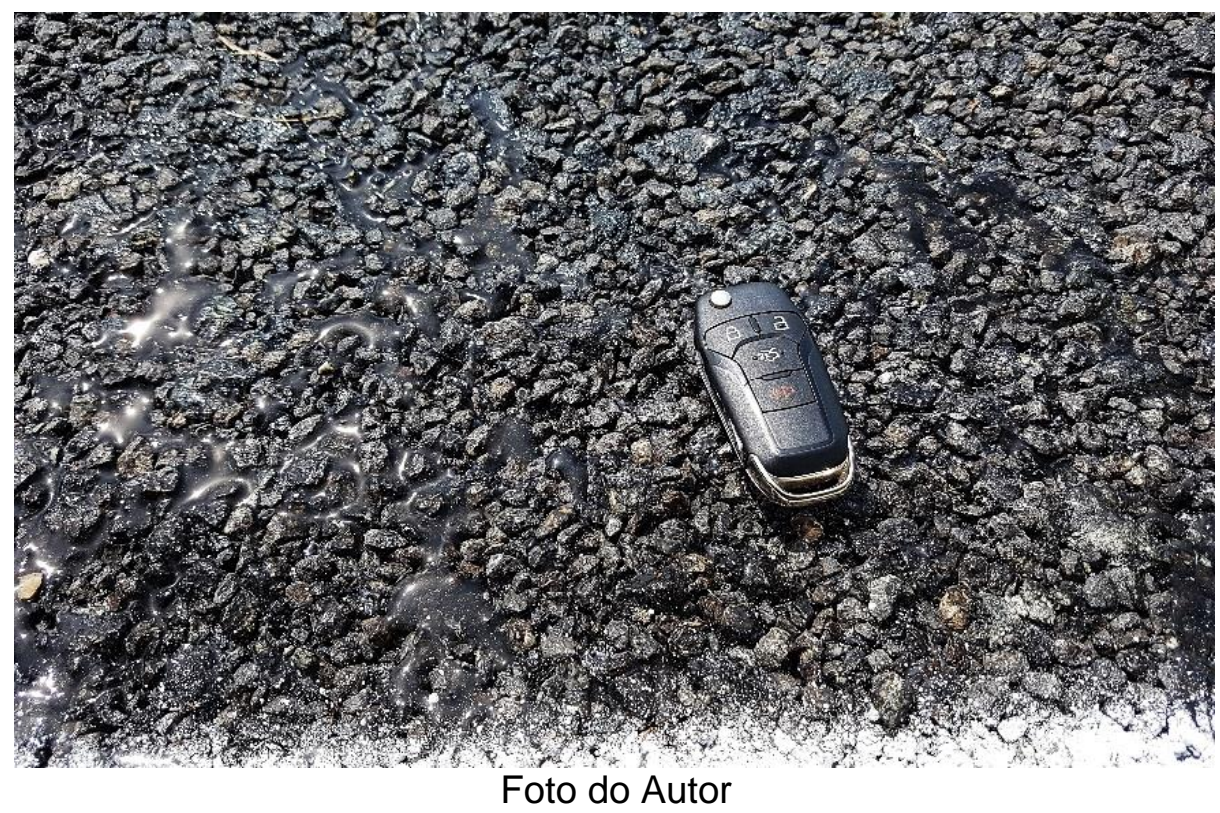




\subsection{Ensaios de textura e atrito}

Para obter dados contínuos e ajudar a não interromper o tráfego para a pesquisa, optou-se pela avaliação inicial da textura e atrito resultantes por meio de técnicas que não interferem na fluidez do trânsito.

Para a avaliação da macrotextura inicial do TSD-AMB, optou-se pela utilização um perfilômetro a laser (Figura 50a). Este equipamento de ensaio mede continuamente as irregularidades do pavimento através da determinação do lapso de tempo que o feixe de laser leva para chegar até a superfície do pavimento e retornar ao sensor, e é descrito pela norma ASTM E1845, que define os padrões de obtenção do parâmetro de macrotextura MPD (Mean Profile Depth).

Para a avaliação do atrito optou-se pela utilização do equipamento Grip-Tester (Figura 50b). Este equipamento mede o atrito existente entre pneu e pavimento em condições simuladas de chuva, ou seja, com a superfície do pavimento molhada. $\mathrm{O}$ coeficiente de atrito é determinado através da relação entre a força vertical e a força horizontal atuantes no equipamento operando segundo o princípio de roda freada e arrasto fixo.

Figura 50 - (a) Representação do perfilômetro a laser; (b) Grip-Tester

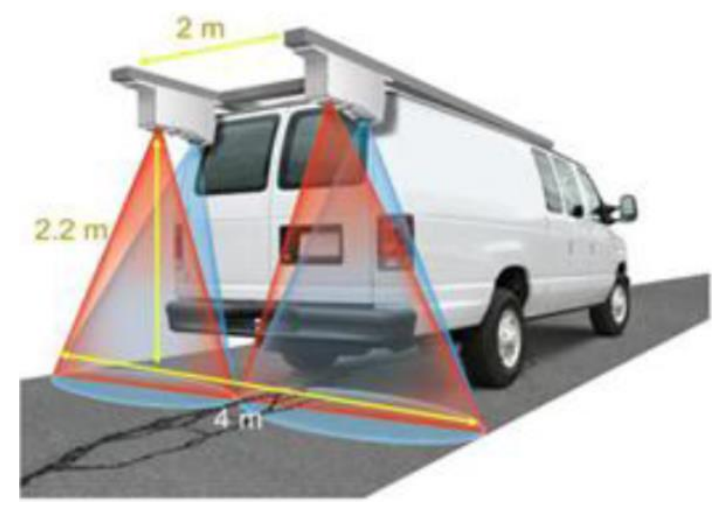

(a)

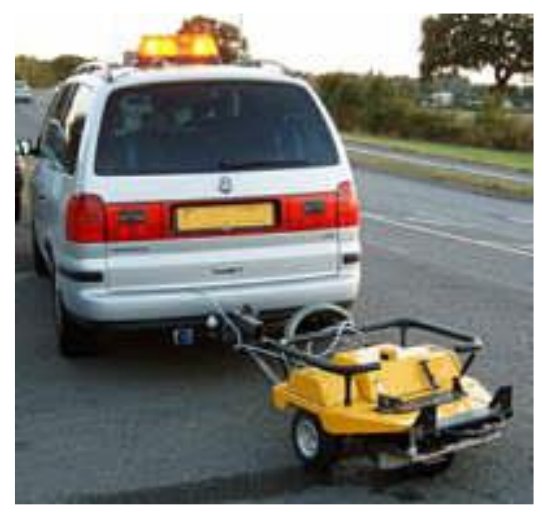

(b)

Fonte: (a) RoadRunner; (b) Santos (2004) 
Os resultados das avaliações de macrotextura e atrito obtidos logo após a execução dos segmentos são apresentados na Figura 51 para o trecho experimental 1, e na Figura 52 para o trecho experimental 2. Cabe ressaltar que os dados de macrotextura (MPD) foram tratados, conforme proposto por Praticò e Vaiana (2015), para obtenção do parâmetro MTD (Mean Texture Depth), tornando possível a comparação dos dados obtidos com o perfilômetro a laser com os resultados de macrotextura obtidos através do ensaio de mancha de areia (ASTM E965), que foram realizados após o décimo oitavo mês de tráfego e serão apresentados em seguida.

Figura 51 - Trecho Experimental 1: (a) Valores de macrotextura inicial (MTD); (b) Valores de atrito inicial (GN)

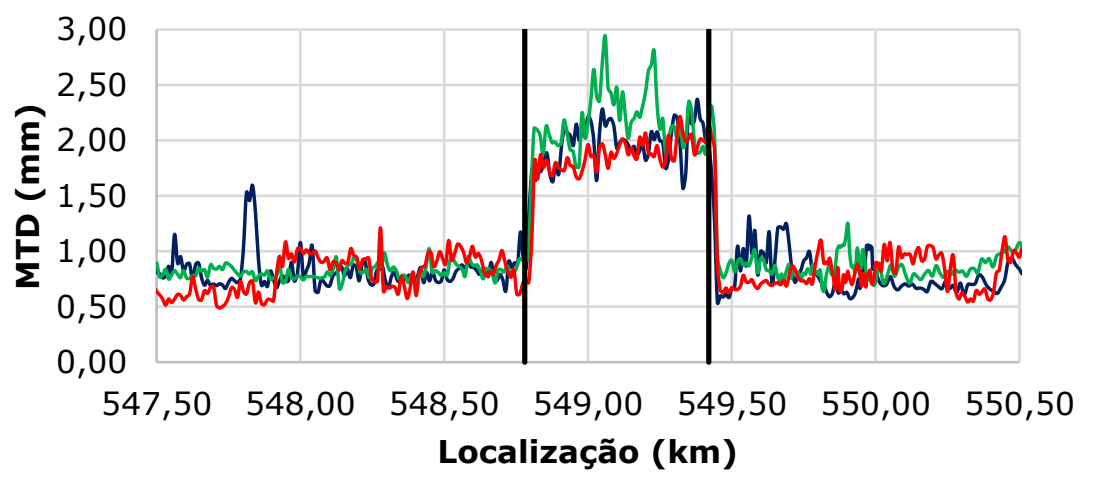

- Faixa 1

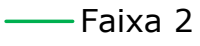

__Faixa 3

—Delimitação Trecho Experimental 1

(a)

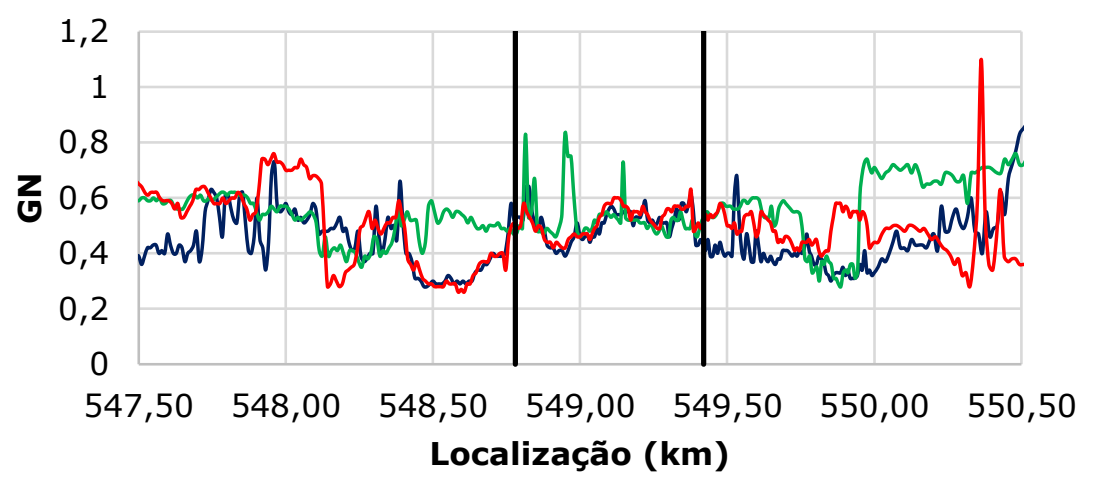

— Faixa 1

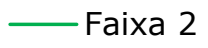

_ Faixa 3

Delimitação Trecho Experimental 1

(b)

Elaborada pelo Autor 
Figura 52 - Trecho Experimental 2: (a) Valores de macrotextura inicial (MPD); (b) Valores de atrito inicial (GN)
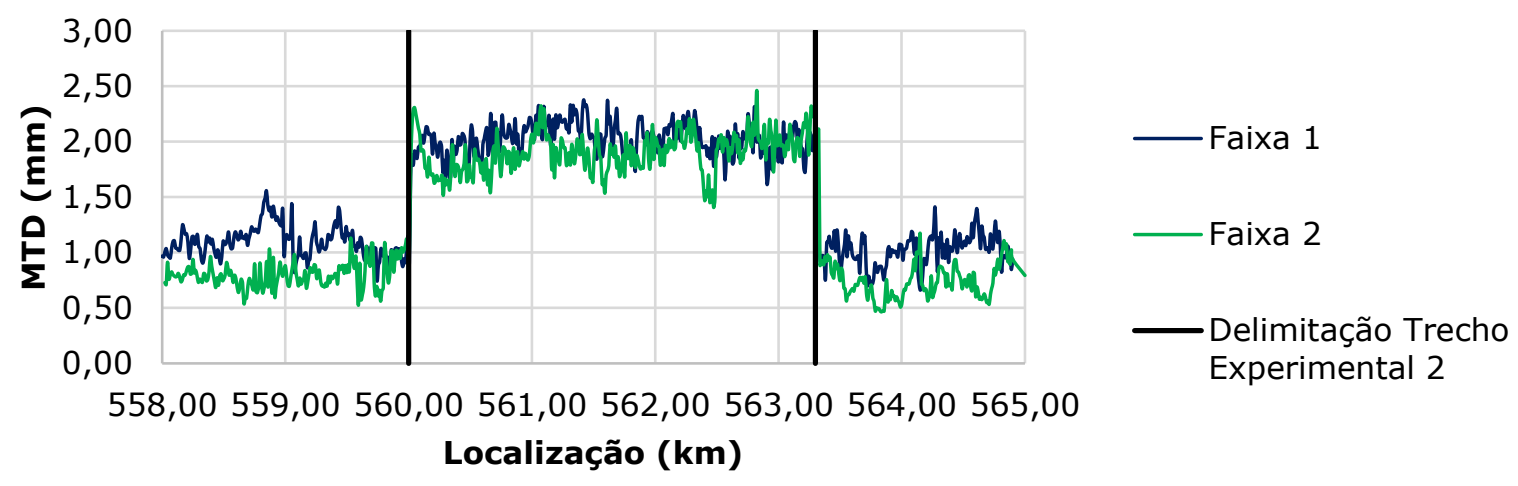

(a)

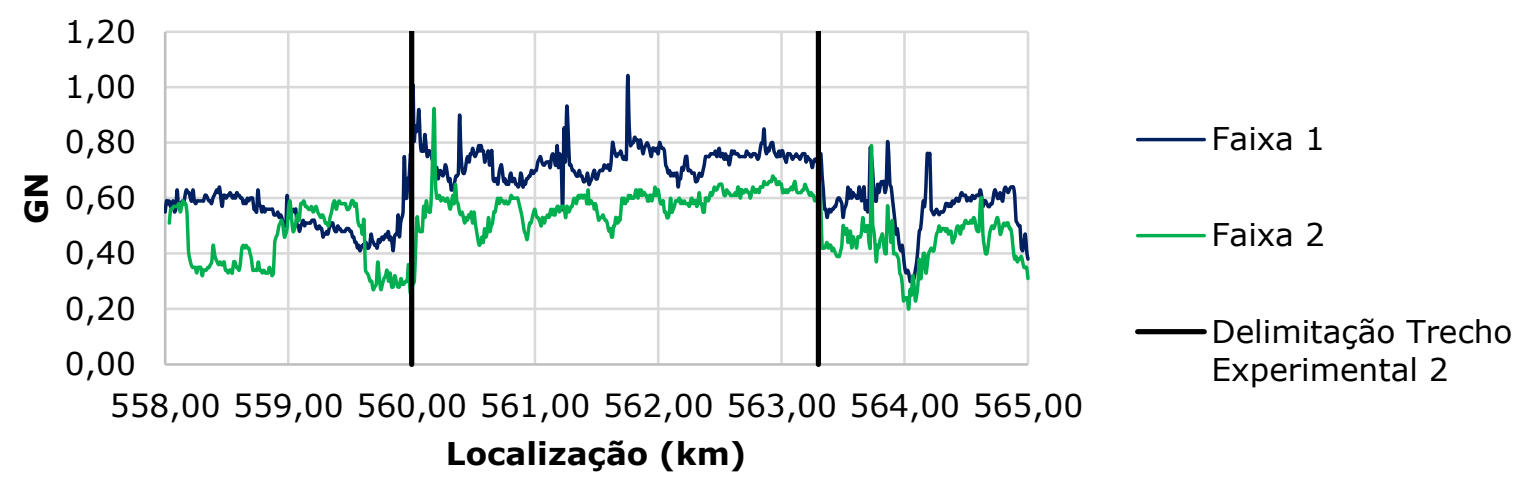

(b)

Elaborada pelo Autor

A Tabela 16 apresenta um resumo dos resultados obtidos para os trechos experimentais e para os segmentos adjacentes (1 quilômetro à montante e 1 quilômetro à jusante dos limites dos trechos experimentais). 
Tabela 16 - Resultados dos ensaios de Macrotextura e Atrito logo após a aplicação do TSD-

AMB

\begin{tabular}{ccccccc}
\hline & \multicolumn{3}{c}{ MTD } & & GN \\
\cline { 2 - 7 } Local & Média & $\begin{array}{c}\text { Desvio } \\
\text { Padrão }\end{array}$ & $\begin{array}{c}\text { Coeficiente } \\
\text { de Variação }\end{array}$ & Média & $\begin{array}{c}\text { Desvio } \\
\text { Padrão }\end{array}$ & $\begin{array}{c}\text { Coeficiente } \\
\text { de Variação }\end{array}$ \\
& & & & & & \\
\hline Trecho experimental 1 & 1,99 & 0,276 & $13,80 \%$ & 0,52 & 0,063 & $12,20 \%$ \\
\hline Trecho experimental 2 & 1,96 & 0,192 & $9,80 \%$ & 0,65 & 0,098 & $14,90 \%$ \\
\hline Segmentos Adjacentes & 0,86 & 0,206 & $24,00 \%$ & 0,48 & 0,117 & $24,20 \%$ \\
\hline
\end{tabular}

Elaborada pelo Autor

Através da análise dos dados, é possível observar que os valores de macrotextura obtidos para o TSD-AMB, por meio da utilização do perfilômetro a laser, foram superiores aos valores obtidos para camadas asfálticas convencionais aplicadas à montante à jusante dos trechos experimentais (Microrrevestimento Asfáltico a Frio e Concreto Betuminoso Usinado a Quente). O valor médio de macrotextura obtido após a aplicação do TSD-AMB, representado pelo parâmetro MTD, foi similar para ambos os trechos experimentais, bem como o desvio padrão obtido nos dois casos, o que demonstra a homogeneidade da textura superficial do TSD-AMB. Em relação ao ensaio de atrito realizado com o Grip-Tester após a aplicação do TSD-AMB, também foram obtidos bons resultados, sendo possível observar que foram alcançados valores superiores aos valores obtidos para camadas asfálticas convencionais.

Posteriormente à liberação da pista ao tráfego, foram realizadas periodicamente avaliações de macrotextura e atrito, a fim de se verificar a evolução destes parâmetros para os trechos experimentais e também para os segmentos adjacentes. Os ensaios de macrotextura passaram a ser realizados através do ensaio de mancha de areia após o décimo oitavo mês, devido a restrições orçamentárias. Para os segmentos adjacentes, foram aproveitados os dados de ensaios de macrotextura realizados pela concessionária para fins de entrega da monitoração periódica ao poder concedente. Em relação aos ensaios de atrito, foram realizados sempre com o equipamento Grip Tester, sendo 
considerados, aos 36 meses, os dados obtidos por Farias (2021). A Tabela 17 apresenta os ensaios realizados em cada período de avaliação.

Tabela 17 - Frequência de realização de ensaios

\begin{tabular}{ccccc}
\hline \multicolumn{3}{c}{ Avaliações Realizadas } \\
\hline \multirow{2}{*}{ Tempo (meses) } & \multicolumn{2}{c}{ Trechos } & \multicolumn{2}{c}{$\begin{array}{c}\text { Trechos } \\
\text { Experimentais }\end{array}$} \\
\cline { 2 - 5 } & Adjacentes \\
\hline 0 & $\checkmark$ & GN & MTD & GN \\
\hline 6 & $\checkmark$ & $\checkmark$ & $\checkmark$ & $\checkmark$ \\
\hline 18 & $\checkmark$ & - & $\checkmark$ & - \\
\hline 30 & - & - & $\checkmark$ & - \\
\hline 36 & $\checkmark$ & $\checkmark$ & - & $\checkmark$ \\
\hline
\end{tabular}

Elaborada pelo Autor

Os resultados obtidos em cada avaliação foram utilizados para determinação do Intervalo de Confiança de $95 \%$ para cada parâmetro, tendo em vista a variabilidade inerente entre os dados e as metodologias de medição.

A Figura 53 apresenta a evolução do parâmetro MTD ao longo do tempo. Tendo em vista que os valores de MTD para os segmentos adjacentes foram mensurados apenas até o trigésimo mês, os valores para 36 meses foram estimados através da utilização da versão AAA do algoritmo de Suavização Exponencial (ETS) do Excel. 
Figura 53 - Intervalo de Confiança de $95 \%$ para a evolução dos parâmetros de macrotextura e dos trechos experimentais e trechos adjacentes ao longo do tempo

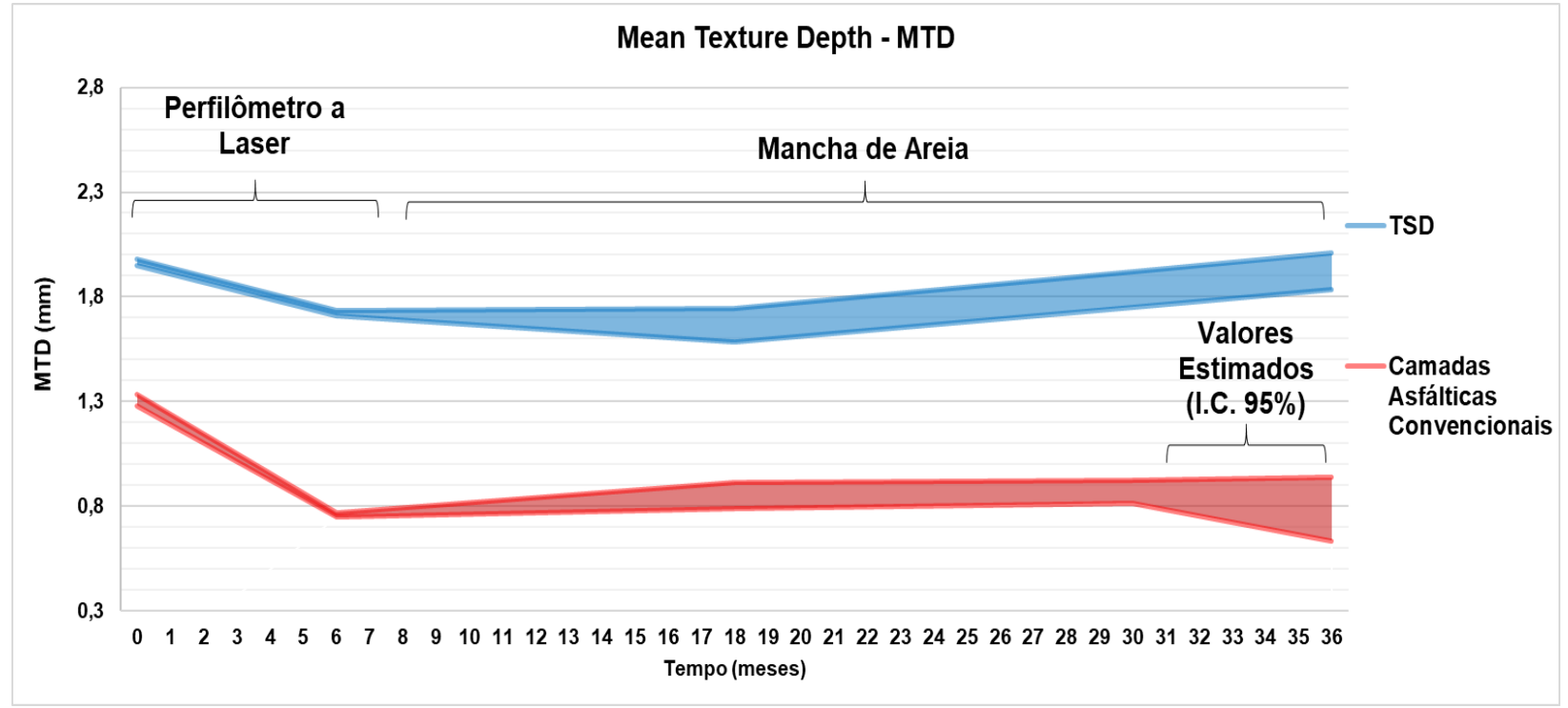

Elaborada pelo Autor

Em relação aos trechos experimentais em TSD-AMB, é possível observar uma leve redução nos valores de macrotextura no período compreendido entre 6 meses e 18 meses após a liberação da pista ao tráfego. Este fator ocorreu provavelmente devido à acomodação dos agregados, sendo este fenômeno natural para este tipo de camada asfáltica. Nota-se que, após este período, os valores de macrotextura apresentaram um leve crescimento. Este fato pode ser justificado pelo desgaste normal deste tipo de técnica, que ocorre através do desprendimento dos agregados de menor dimensão da camada superior do TSD-AMB, expondo os agregados de maior dimensão da camada inferior.

Em relação aos segmentos adjacentes, também é possível notar uma redução inicial nos valores de MTD. Este fato pode ter ocorrido pela realização da fresagem de camadas de MRF e posterior recomposição com CBUQ, devido à campanha de manutenção periódica dos pavimentos realizada pela concessionária. Após este período, pode-se notar a manutenção dos valores de macrotextura ao longo do tempo. 
Para validação estatística dos dados, foi realizada, inicialmente, uma análise comparativa entre variâncias, através da utilização do teste $F$, e posteriormente, uma análise estatística para comparação entre médias, através da utilização do teste $T$ de Student. A Tabela 18 apresenta os resultados da realização do teste $\mathrm{F}$ e a Tabela 19 apresenta os resultados da realização do teste T de Student para os parâmetros MTD da camada de TSD-AMB.

Tabela 18 - Teste F para comparação entre variância dos dados de MTD obtidos ao longo do tempo para o trecho experimental em TSD-AMB

\begin{tabular}{|c|c|c|c|}
\hline \multicolumn{4}{|c|}{ MTD - Teste F para verificação da igualdade entre a variância de duas amostras } \\
\hline Comparativo & Valor-p & Análise & Observação \\
\hline T0 & \multirow{2}{*}{$1,18 \mathrm{E}-07$} & \multirow{2}{*}{$\begin{array}{c}\text { Uma vez que o valor-p é inferior a 0,05, a } \\
\text { hipótese nula de igualdade da variância para } \\
\text { as duas amostras pode ser rejeitada. Existe } \\
\text { forte evidência de que as variâncias das duas } \\
\text { amostras são diferentes. }\end{array}$} & \multirow{2}{*}{$\begin{array}{l}\text { Realizar teste T } \\
\text { presumindo } \\
\text { variâncias } \\
\text { diferentes }\end{array}$} \\
\hline T6 & & & \\
\hline T6 & \multirow{2}{*}{$4,46 E-48$} & \multirow{2}{*}{$\begin{array}{l}\text { Uma vez que o valor-p é inferior a 0,05, a } \\
\text { hipótese nula de igualdade da variância para } \\
\text { as duas amostras pode ser rejeitada. Existe } \\
\text { forte evidência de que as variâncias das duas } \\
\text { amostras são diferentes. }\end{array}$} & \multirow{2}{*}{$\begin{array}{l}\text { Realizar teste T } \\
\text { presumindo } \\
\text { variâncias } \\
\text { diferentes }\end{array}$} \\
\hline T18 & & & \\
\hline T18 & \multirow{2}{*}{0,2856} & \multirow{2}{*}{$\begin{array}{c}\text { Uma vez que o valor-p é superior a } 0,05 \text {, não } \\
\text { existe forte evidência de que a variância das } \\
\text { duas amostras é diferente. }\end{array}$} & \multirow{2}{*}{$\begin{array}{l}\text { Realizar teste T } \\
\text { presumindo } \\
\text { variâncias } \\
\text { equivalentes }\end{array}$} \\
\hline T36 & & & \\
\hline TO & \multirow{2}{*}{ 1,34E-32 } & \multirow{2}{*}{$\begin{array}{l}\text { Uma vez que o valor-p é inferior a 0,05, a } \\
\text { hipótese nula de igualdade da variância para } \\
\text { as duas amostras pode ser rejeitada. Existe } \\
\text { forte evidência de que as variâncias das duas } \\
\text { amostras são diferentes. }\end{array}$} & \multirow{2}{*}{$\begin{array}{l}\text { Realizar teste T } \\
\text { presumindo } \\
\text { variâncias } \\
\text { diferentes }\end{array}$} \\
\hline T36 & & & \\
\hline
\end{tabular}

Fonte: Elaborada pelo Autor 
Tabela 19 - Teste T para comparação entre médias dos dados de MTD obtidos ao longo do tempo para o trecho experimental em TSD-AMB

\begin{tabular}{ccc}
\hline \multicolumn{2}{c}{ MTD - Teste T de Student para verificação da igualdade entre a média de duas } \\
populações
\end{tabular}

Fonte: Elaborada pelo Autor

A Figura 54 apresenta a evolução do parâmetro GN ao longo do tempo.

Figura 54 - Intervalo de Confiança de 95\% para a evolução dos parâmetros de atrito dos trechos experimentais e dos trechos adjacentes ao longo do tempo

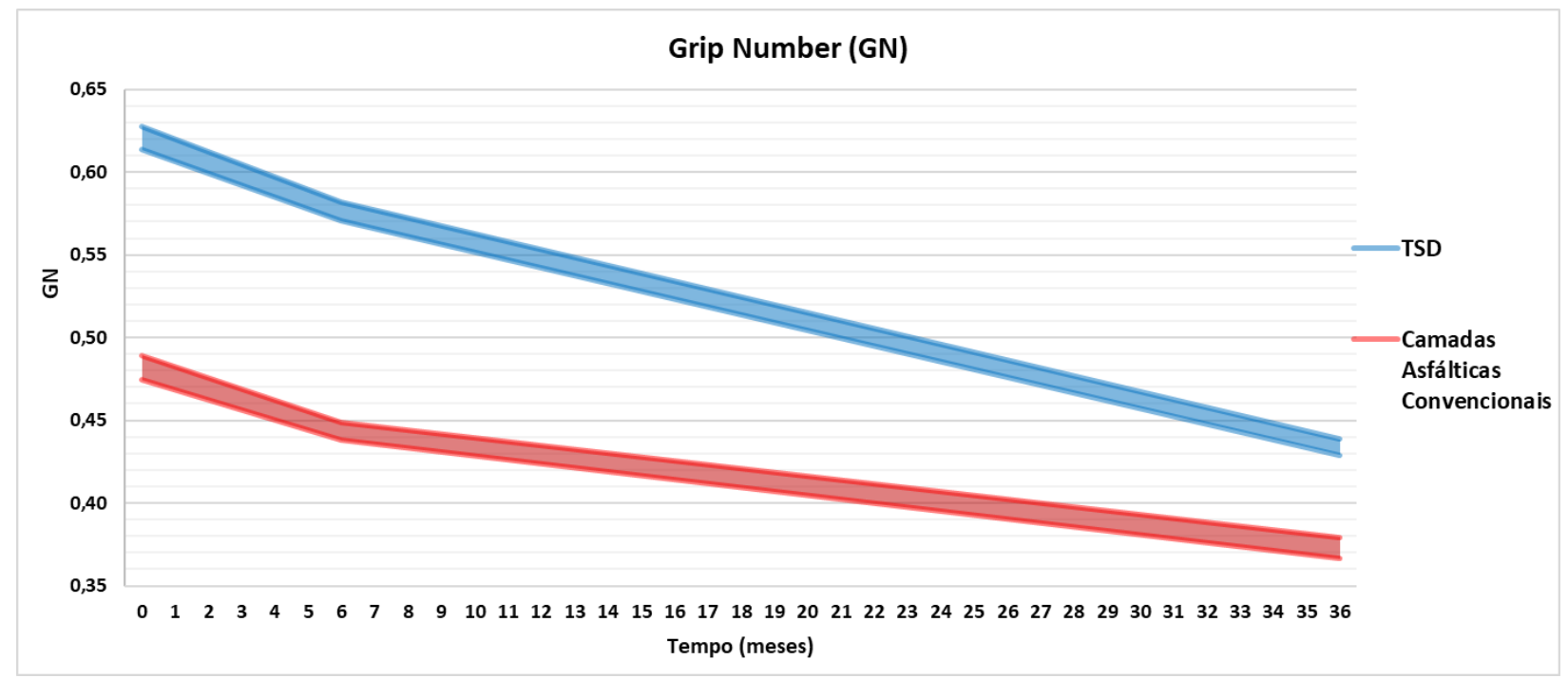

Elaborada pelo Autor 
É possível notar que houve uma redução do GN ao longo do tempo, devido provavelmente ao polimento dos agregados. Apesar desta redução ser bastante similar para os trechos experimentais e trechos adjacentes, nota-se uma redução um pouco mais acentuada para os trechos em TSD-AMB. Este fato pode ser justificado também pela provável realização de fresagem e recomposição de alguns segmentos nesta área, rejuvenescendo alguns pontos isolados, contribuindo assim para esta leve diferença de decaimento dos valores.

Para validação estatística dos dados, também foi realizada uma análise comparativa entre variâncias, através da utilização do teste $F$, e uma análise estatística para comparação entre médias, através da utilização do teste T de Student. A Tabela 20 apresenta os resultados da realização do teste $\mathrm{F}$ e a Tabela 21 apresenta os resultados da realização do teste T de Student para os parâmetros MTD da camada de TSD-AMB.

Tabela 20 - Teste F para comparação entre variância dos dados de GN obtidos ao longo do tempo para o trecho experimental em TSD-AMB

\begin{tabular}{|c|c|c|c|}
\hline \multicolumn{4}{|c|}{ Grip Number - Teste F para verificação da igualdade entre a variância de duas amostras } \\
\hline Comparativo & Valor-p & Análise & Observação \\
\hline T0 & \multirow{2}{*}{0,19087316} & \multirow{2}{*}{$\begin{array}{l}\text { Uma vez que o valor-p é superior a } 0,05 \text {, } \\
\text { não existe forte evidência de que a variância } \\
\text { das duas amostras é diferente. }\end{array}$} & \multirow{2}{*}{$\begin{array}{l}\text { Realizar teste T } \\
\text { presumindo } \\
\text { variâncias } \\
\text { equivalentes }\end{array}$} \\
\hline T6 & & & \\
\hline T6 & \multirow[b]{2}{*}{0,00012957} & $\begin{array}{l}\text { Uma vez que o valor-p é inferior a } 0,05 \text {, a } \\
\text { hipótese nula de igualdade da variância para }\end{array}$ & \multirow{2}{*}{$\begin{array}{l}\text { Realizar teste T } \\
\text { presumindo } \\
\text { variâncias } \\
\text { diferentes }\end{array}$} \\
\hline T36 & & $\begin{array}{c}\text { as duas amostras pode ser rejeitada. Existe } \\
\text { forte evidência de que as variâncias das } \\
\text { duas amostras são diferentes. }\end{array}$ & \\
\hline TO & \multirow[b]{2}{*}{0,01149487} & $\begin{array}{l}\text { Uma vez que o valor-p é inferior a } 0,05 \text {, a } \\
\text { hipótese nula de igualdade da variância para }\end{array}$ & \multirow{2}{*}{$\begin{array}{l}\text { Realizar teste } T \\
\text { presumindo } \\
\text { variâncias } \\
\text { diferentes }\end{array}$} \\
\hline T36 & & $\begin{array}{c}\text { as duas amostras pode ser rejeitada. Existe } \\
\text { forte evidência de que as variâncias das } \\
\text { duas amostras são diferentes. }\end{array}$ & \\
\hline
\end{tabular}

Fonte: Elaborada pelo Autor 
Tabela 21 - Teste T para comparação entre médias dos dados de MTD obtidos ao longo do tempo para o trecho experimental em TSD-AMB

\begin{tabular}{ccc}
\hline Grip Number - Teste T de Student para verificação da igualdade entre a média de duas \\
populaços
\end{tabular}

Fonte: Elaborada pelo Autor

Os resultados obtidos demonstram que o TSD-AMB continua a apresentar elevados valores de macrotextura e atrito, mesmo após a acomodação dos agregados pelo tráfego e o provável polimento inicial dos agregados. 


\section{ANÁLISE DOS RESULTADOS}

\subsection{Avaliação da eficiência do TSD-AMB na redução de acidentes por derrapagem em pista molhada}

Após a execução dos segmentos experimentais, deu-se continuação à monitoração periódica da ocorrência de acidentes, com a finalidade de se verificar se o emprego do TSD-AMB foi eficiente para o controle e redução destes eventos.

\subsubsection{Comparação direta - Densidade de acidentes Antes e Após a aplicação do TSD-AMB}

Para a avaliação da eficiência do TSD-AMB no que diz respeito à redução de acidentes, foram contabilizados os dados de tráfego, os dados pluviométricos e os dados de acidentes ocorridos dentro dos limites dos segmentos experimentais, antes e após a data de aplicação do TSD-AMB e liberação dos segmentos ao tráfego.

As densidades médias de acidentes foram calculadas separadamente para condições de pista seca e pista molhada. Para realização desta análise, separou-se o volume de tráfego da rodovia nos momentos em que foi identificada a ocorrência de chuvas daqueles momentos em que o pluviógrafo não registrou a ocorrência de chuvas. Ressalta-se que para esta análise, foi possível utilizar apenas os dados de tráfego e acidentes após o ano 2014, tendo em vista que os pluviógrafos foram instalados neste ano.

A Figura 55 apresenta a evolução da densidade de acidentes em pista seca e pista molhada para os trechos experimentais 1 e 2, além da evolução para ambos os trechos agrupados. 
Figura 55 - Análise da evolução da densidade média de acidentes para os períodos antes e depois: (a) Trecho Experimental 1; (b) Trecho Experimental 2 e (c) Trechos Experimentais Agrupados
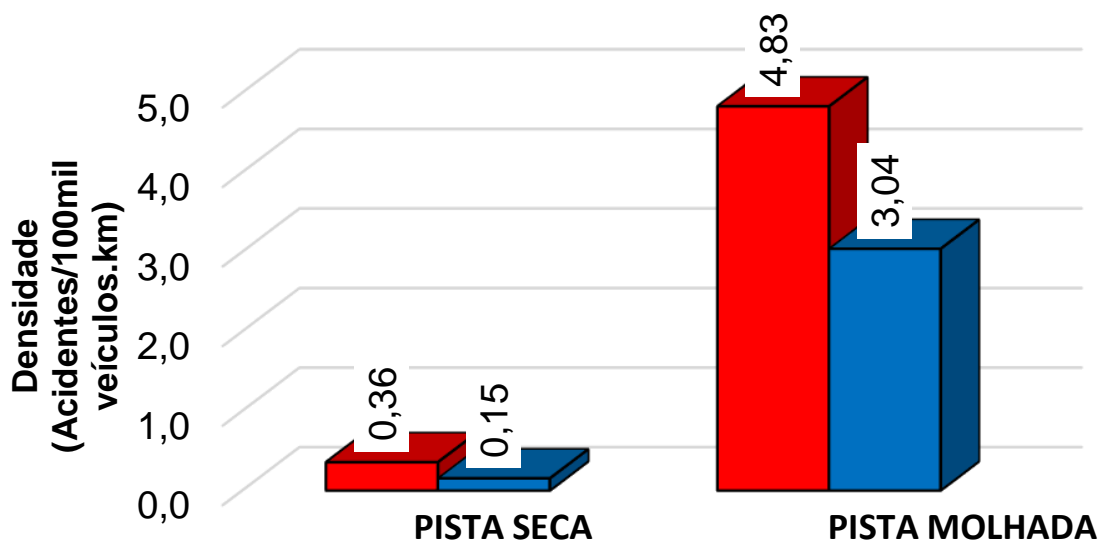

-Período de 4 anos antes da aplicação do TSD-AMB

$\square$ Período de 3 anos após a aplicação do TSD-AMB

(a)

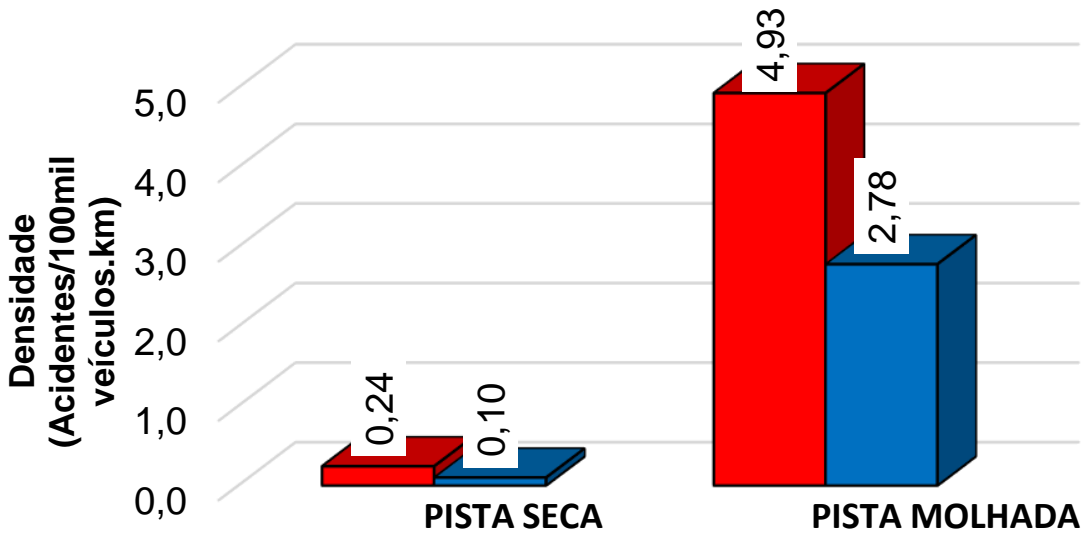

$\square$ Período de 4 anos antes da aplicação do TSD-AMB

$\square$ Período de 3 anos após a aplicação do TSD-AMB

(b)

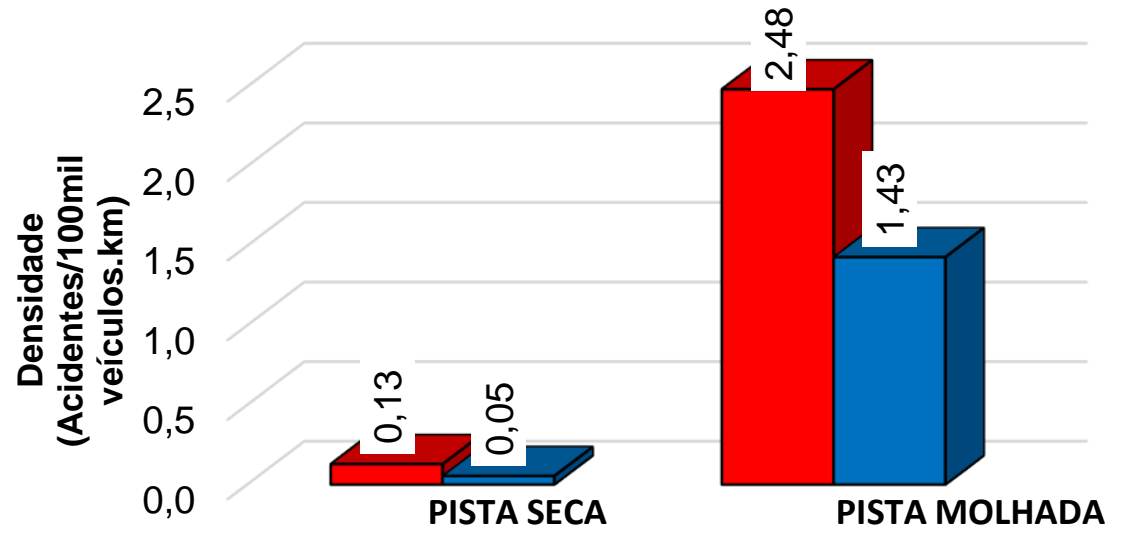

$\square$ Período de 4 anos antes da aplicação do TSD-AMB

$\square$ Período de 3 anos após a aplicação do TSD-AMB

(c)

Elaborada pelo Autor 
Através da análise direta entre o período de 4 anos antes com o período de 3 anos após a aplicação do TSD-AMB nestes segmentos, é possível notar uma redução significativa na densidade média de acidentes, principalmente em condições de pista molhada. A redução média obtida em condições de pista seca foi de 58,2\% (57,0\% para o trecho experimental 1 e 58,5\% para o trecho experimental 2), e a redução média obtida em condições de pista molhada foi de $42,0 \%$ (37,1\% para o trecho experimental $1 \mathrm{e}$ $43,6 \%$ para o trecho experimental 2 ).

Um fator importante a se destacar é que, considerando todo o período de análise (7 anos), a densidade média de acidentes em condições de pista molhada foi sempre superior à densidade média de acidentes em condições de pista seca (em média 21,7 vezes superior), apesar de ser registrada condição de chuvas em apenas $14,5 \%$ do tempo nesta região. Isto demonstra a criticidade da ocorrência de chuvas na segurança viária, evidenciando a importância de se desenvolverem técnicas de viabilidade econômica para melhoria das condições de atrito e redução dos acidentes em condições climáticas desfavoráveis.

Uma vez que a ocorrência de acidentes é um fenômeno aleatório, os dados de densidade de acidentes são bastante variáveis ao longo do tempo, oscilando ao redor de um valor médio. Esta alta variabilidade pode influenciar na análise da eficácia do tratamento, tendo em vista que no período anterior ao tratamento poderiam estar ocorrendo valores de densidade acima do valor médio histórico para o segmento em questão. Sendo assim, se faz necessário realizar a utilização de testes de análise estatística para comprovação dos resultados obtidos.

Para este estudo, optou-se por calcular a densidade mensal de acidentes, tanto em pista seca quanto em pista molhada, no período anterior e posterior à aplicação do TSD-AMB. De forma a buscar maior precisão nas análises, buscou-se ampliar a base de dados. Para possibilitar a utilização dos dados referentes aos períodos anteriores à 2014, quando ainda não se dispunha de dados referentes à ocorrência de chuvas, calculou-se a proporção de tempo com e sem ocorrência de chuvas nesta região, considerando os dados do pluviógrafo de 2014 a 2020. Ressalta-se que, devido à sazonalidade, ou seja, a existência de estações mais secas e estações mais chuvosas, esta análise foi realizada 
separadamente mês a mês, e os resultados foram aplicados para estimar o volume de tráfego em pista seca e molhada desde 2012. Os períodos anteriores a esta data foram desprezados das análises, tendo em vista que se tratava do período inicial de atuação da concessionária neste trecho da rodovia, onde ainda eram tomadas medidas habituais buscando a redução de acidentes nos trechos críticos, tais como implantação de radares para controle de velocidade e melhoria das condições de sinalização, conforme relatado no item 3.1. do capítulo 3 desta dissertação. Salienta-se que estas melhorias realizadas pela concessionária no período inicial de sua atuação do trecho são efetivas para a redução dos acidentes, mas possuem uma certa limitação ao se considerarem os eventos que ocorrem em condições de pista molhada, principalmente nos casos de curvas reversas, em que há alta probabilidade de formação de lâminas d'água extensas e espessas, na região de transição, onde a superelevação é zero, que favorecem a ocorrência da hidroplanagem.

A Figura 56 e Figura 57 apresentam a evolução da densidade mensal de acidentes calculadas para os trechos experimentais separadamente e a Figura 58 apresenta a evolução da densidade mensal de acidentes para os trechos experimentais agrupados.

Figura 56 - Evolução da densidade mensal de acidentes - Trecho experimental 1

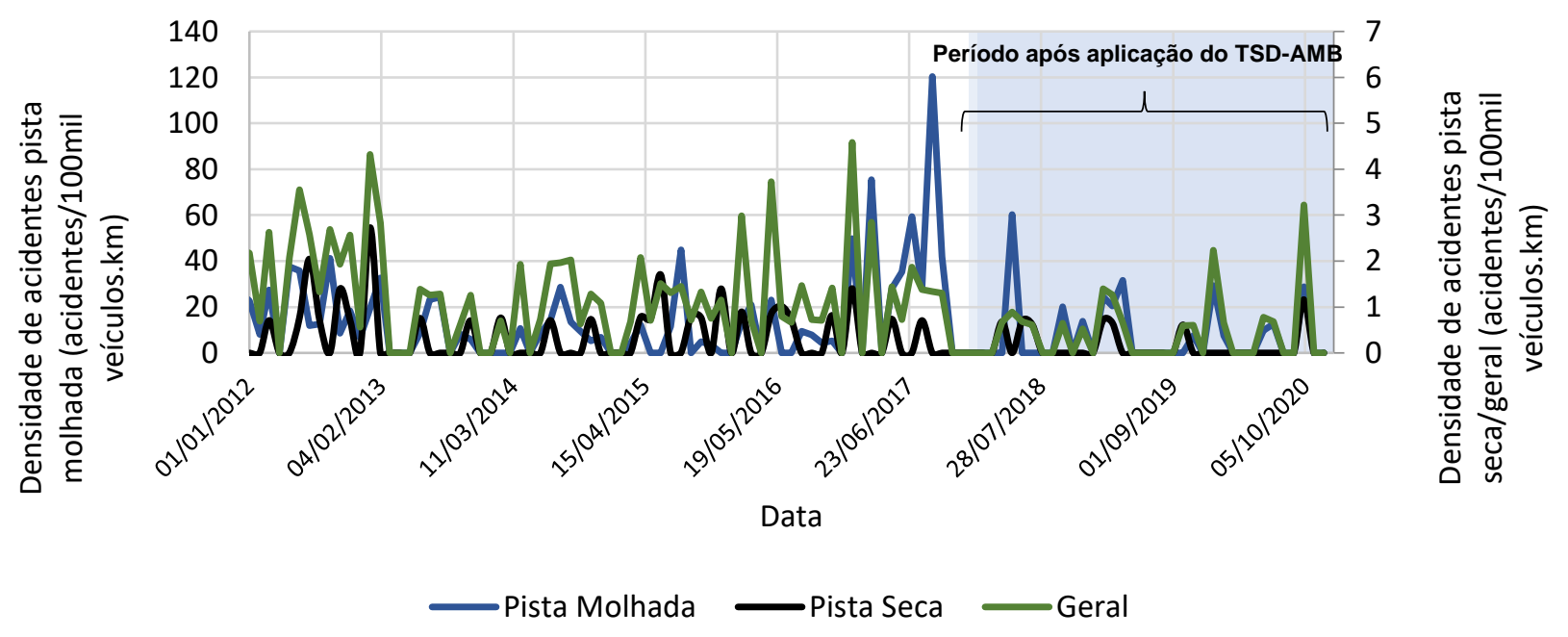

Elaborada pelo Autor 
Figura 57 - Evolução da densidade mensal de acidentes - Trecho experimental 2

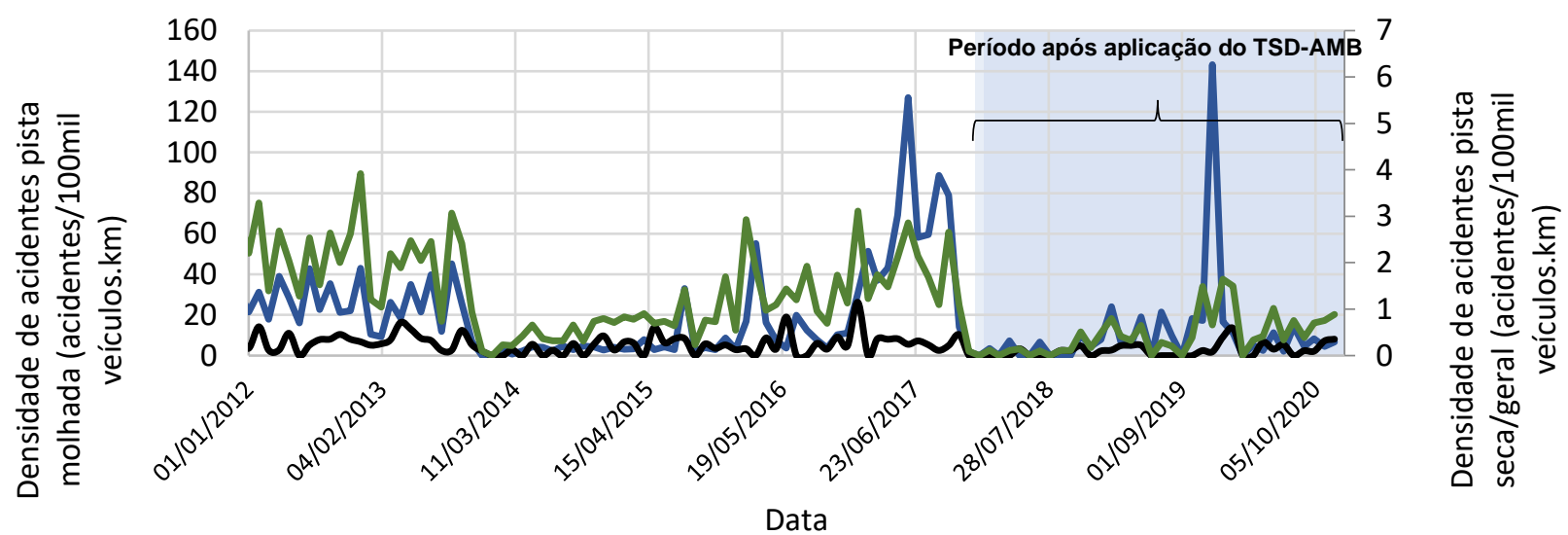

Pista Molhada —Pista Seca $\longrightarrow$ Geral

Elaborada pelo Autor

Figura 58 - Evolução da densidade mensal de acidentes - Trechos experimentais agrupados

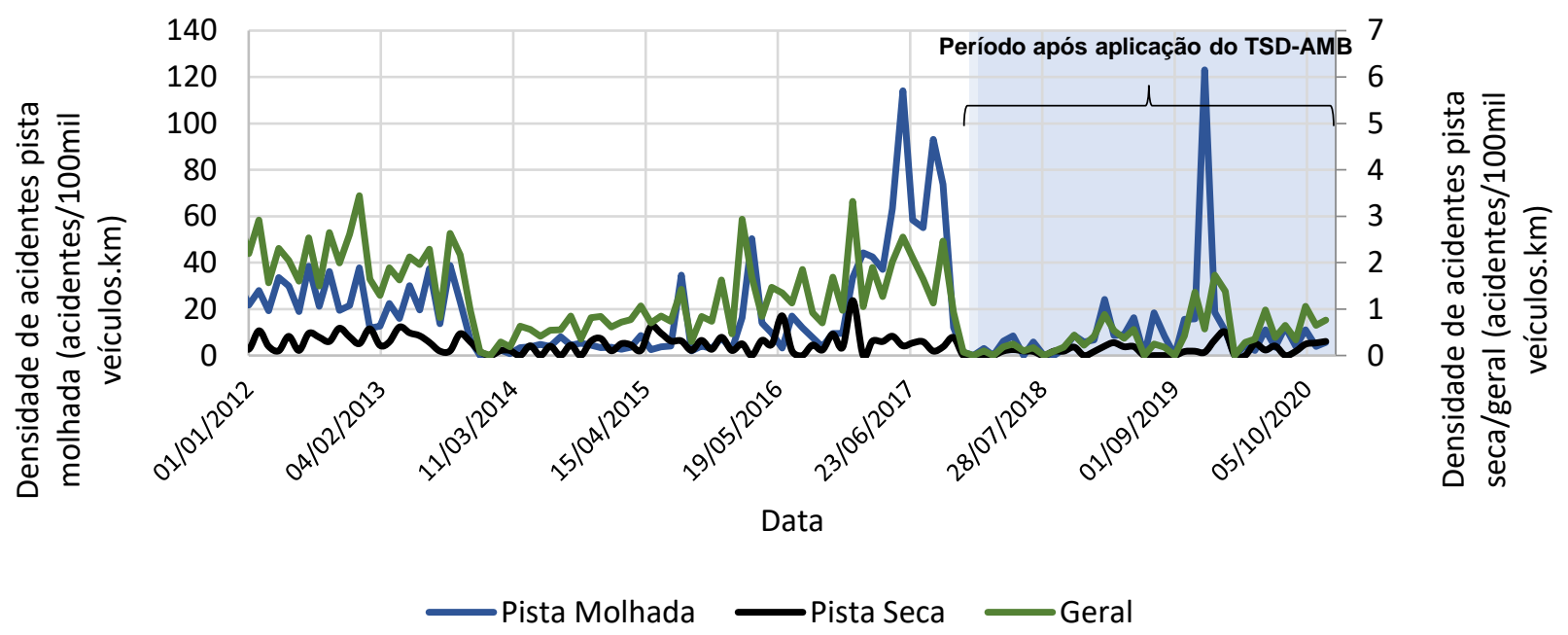

Elaborada pelo Autor

Observa-se uma tendência de redução nos valores de densidade mensal de acidentes no período posterior à aplicação do TSD-AMB. De qualquer forma, é possível inferir também a alta variabilidade dos dados, devido principalmente à sazonalidade. $\mathrm{Da}$ posse destes dados, foram criados histogramas, de forma a se verificar a distribuição de probabilidade dos dados, para os períodos antes e depois, conforme Tabela 22. 
Tabela 22 - Histogramas para a densidade mensal de acidentes do trecho experimental 1

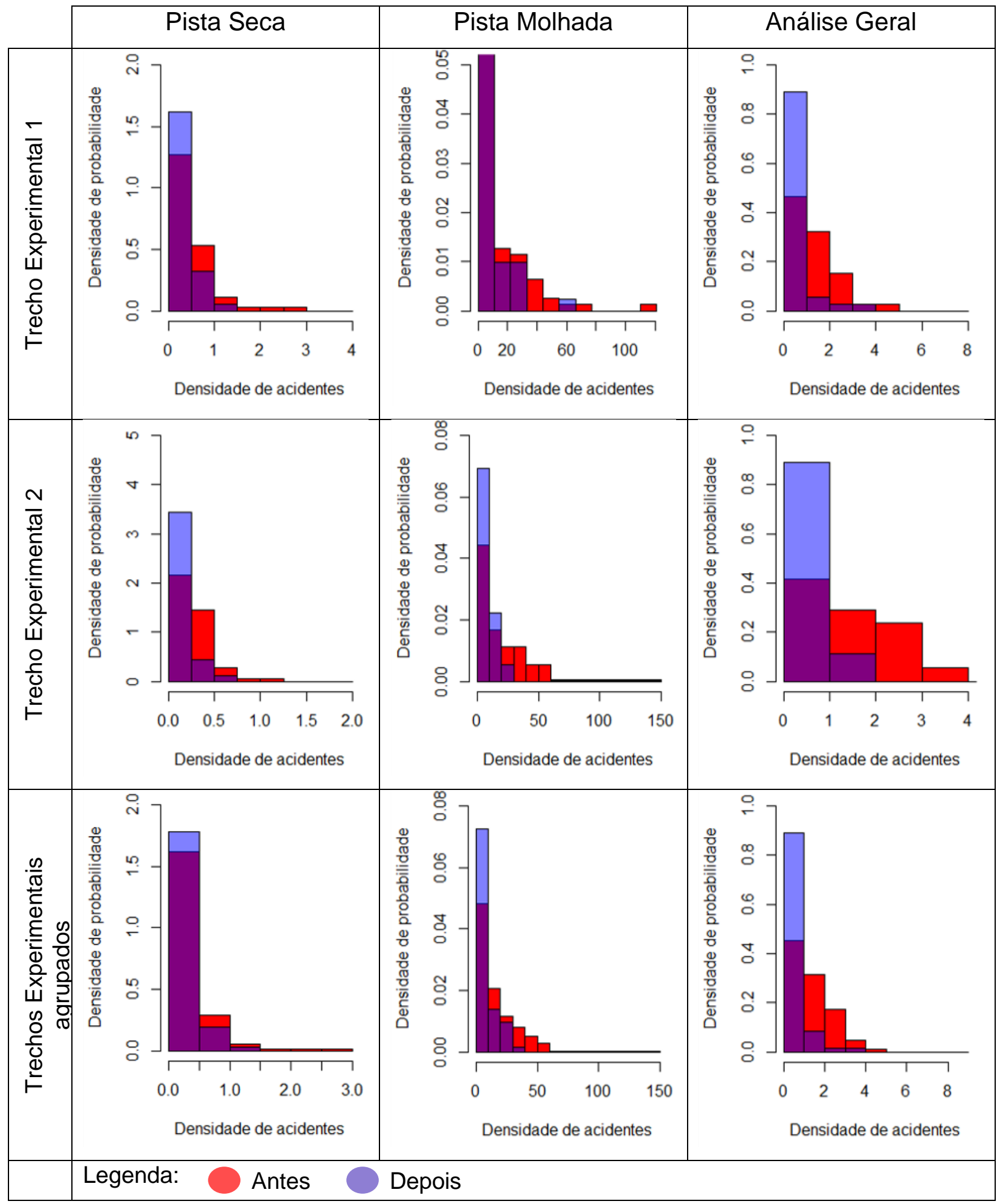

Elaborada pelo Autor 
Observa-se que os dados não seguem uma distribuição normal, assemelhandose mais a uma distribuição exponencial. É possível notar, através da análise destes histogramas, que a densidade mensal de acidentes no período posterior à aplicação do TSD-AMB se aproximou mais do eixo y, ou seja, do valor de densidade de acidentes 0 , indicando uma redução da densidade neste período. De qualquer forma, a escolha do teste estatístico apropriado para análise dos dados deve levar em consideração diversos fatores, sendo um deles a distribuição de probabilidades. Portanto, uma vez que esta distribuição não se assemelha à distribuição normal (um pressuposto para os testes paramétricos), optou-se pela busca de testes não paramétricos.

Dentre os diversos testes disponíveis, considerou-se que o mais adequado para esta análise seria o teste de Mann-Whitney (Wilcoxon rank sum test), que faz a comparação entre duas populações, buscando evidências de diferenças entre elas. Para a realização dos testes foi utilizado o software R. A Tabela 23 apresenta os principais resultados obtidos para a comparação entre as populações.

Tabela 23 - Resultados do teste de Mann-Whitney para comparação entre as densidades mensais antes e depois da aplicação do TSD-AMB.

\begin{tabular}{|c|c|c|c|c|c|c|}
\hline \multicolumn{2}{|c|}{$\begin{array}{l}2012 / 2017 \\
2018 / 2020\end{array}$} & Pista Seca & \multicolumn{2}{|c|}{ Pista Molhada } & \multicolumn{2}{|c|}{ Geral } \\
\hline \multirow{3}{*}{$\begin{array}{c}\text { Trecho experimental } \\
1\end{array}$} & Valor $p$ & $1,92 \mathrm{E}-02$ & & $E-03$ & & \\
\hline & $\begin{array}{l}\text { Difference in } \\
\text { location }\end{array}$ & $-3,22 E-06$ & \multicolumn{2}{|c|}{$-4,45$} & \multicolumn{2}{|c|}{$-0,71$} \\
\hline & $\mathrm{Cl} 90 \%$ & $-3,45 E-05 \quad-2,67 E-05$ & $-8,25$ & $-1,37 E-05$ & $-1,09$ & $-0,57$ \\
\hline \multirow{3}{*}{$\begin{array}{c}\text { Trecho experimental } \\
2\end{array}$} & Valor $p$ & $1,38 \mathrm{E}-04$ & \multicolumn{2}{|c|}{$2,30 \mathrm{E}-03$} & \multicolumn{2}{|c|}{$1,17 \mathrm{E}-08$} \\
\hline & $\begin{array}{l}\text { Difference in } \\
\text { location }\end{array}$ & $-0,12$ & \multicolumn{2}{|c|}{$-5,36$} & \multicolumn{2}{|c|}{$-0,82$} \\
\hline & $\mathrm{Cl} 90 \%$ & $-0,06$ & $-11,76$ & $-2,85$ & $-1,11$ & $-0,63$ \\
\hline \multirow{3}{*}{$\begin{array}{l}\text { Trechos } \\
\text { experimentais } \\
\text { agrupados }\end{array}$} & Valor $p$ & $3,91 \mathrm{E}-04$ & \multicolumn{2}{|c|}{$2,85 \mathrm{E}-06$} & \multicolumn{2}{|c|}{$2,37 \mathrm{E}-13$} \\
\hline & $\begin{array}{l}\text { Difference in } \\
\text { location }\end{array}$ & 0,00 & \multicolumn{2}{|c|}{$-5,20$} & \multicolumn{2}{|c|}{$-0,74$} \\
\hline & Cl $90 \%$ & $-2,47 \mathrm{E}-05$ & $-8,12$ & $-3,38$ & $-0,93$ & $-0,64$ \\
\hline
\end{tabular}

Elaborada pelo Autor 
Observa-se que para todas as comparações realizadas, o valor $p$ foi inferior a 0,02 , evidenciando estatisticamente que existem diferenças entre as populações a um nível de significância de $2 \%$. O parâmetro Difference in Location apresenta a mediana da diferença entre as observações inseridas na análise, sendo que valores negativos indicam a ocorrência de uma redução na densidade de acidentes. Tendo em vista a variabilidade dos dados, também foi calculado o intervalo de confiança de $90 \%$ para este parâmetro, mostrando que a redução da densidade de acidentes em alguns pontos específicos pode ser ainda maior do que o observado até então. Observa-se em geral uma redução mais acentuada em condições de pista molhada, embora em qualquer condição tenha sido comprovada a redução da densidade de acidentes.

Os resultados demonstram que a melhoria da textura superficial do pavimento auxiliou na redução da densidade de acidentes nestes segmentos sinuosos, que até então eram considerados como os mais críticos da rodovia. A utilização de camada asfáltica com elevados valores de macrotextura é uma das formas mais eficazes de aumentar consideravelmente $\mathrm{o}$ atrito entre pneu e pavimento, devido ao aumento da histerese (que pode gerar efeitos positivos de segurança em condições de pavimento seco) e à melhoria da drenagem superficial (gerando efeitos positivos de segurança em condições de pavimento molhado).

\subsubsection{Comparação dos resultados com segmentos de referência}

Conforme apresentado na revisão bibliográfica deste estudo, diversos são os fatores que podem contribuir para a ocorrência de acidentes, sendo estes fatores associados ao comportamento humano, aos veículos e à via e ao meio ambiente. Uma vez que estes fatores são independentes, não se pode afirmar que a implementação de uma solução isolada de pavimento resolva todos os outros problemas existentes. Desta forma, uma vez que estas outras variáveis continuam atuando, elas podem afetar, tanto positivamente quanto negativamente, as análises de efetividade da solução de pavimento aplicada. Sendo assim, uma forma de avaliação da eficácia da solução asfáltica na redução da densidade de acidentes se dá através da comparação entre os segmentos 
tratados com segmentos de referência, que possuam características similares (geometria, pavimento etc.).

Sendo assim, optou-se pela comparação entre a densidade de acidentes registrada nos trechos experimentais com o trecho de serra situado entre os quilômetros 500-SP e 58-PR, que totaliza 127 quilômetros de extensão. Esta análise foi realizada tanto para a pista sul quanto para a pista norte da rodovia. No caso da pista sul, foram desconsiderados os trechos experimentais em TSD-AMB e os 2 quilômetros posteriores a estes trechos, tendo em vista que a comparação dos dados entre segmentos da pista sul pode ser influenciada devido ao fenômeno de transferência de acidentes para segmentos posteriores, que será discutido no item 4.2.

A Figura 59 apresenta a evolução da densidade de acidentes para o segmento de serra da pista sul (desconsiderando os trechos experimentais), e a Figura 60 apresenta a evolução da densidade de acidentes para o segmento de serra da pista norte. Ressaltase que para esta análise foram considerados apenas os anos em que os pluviógrafos já se encontravam em funcionamento.

Figura 59 - Dados históricos de ocorrência de acidentes para todo o trecho em serra na pista sul, excluindo os trechos experimentais.

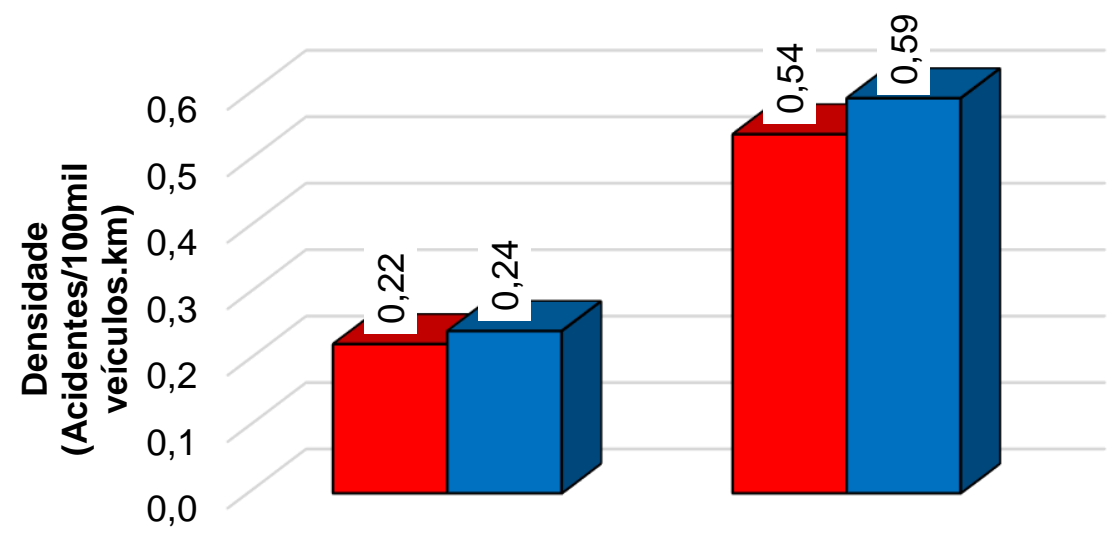

Elaborada pelo Autor
Período de 4 anos antes da aplicação do TSD-AMB

-Período de 3 anos após a aplicação do TSD-AMB 
Figura 60 - Dados históricos de ocorrência de acidentes para todo o trecho em serra na pista norte
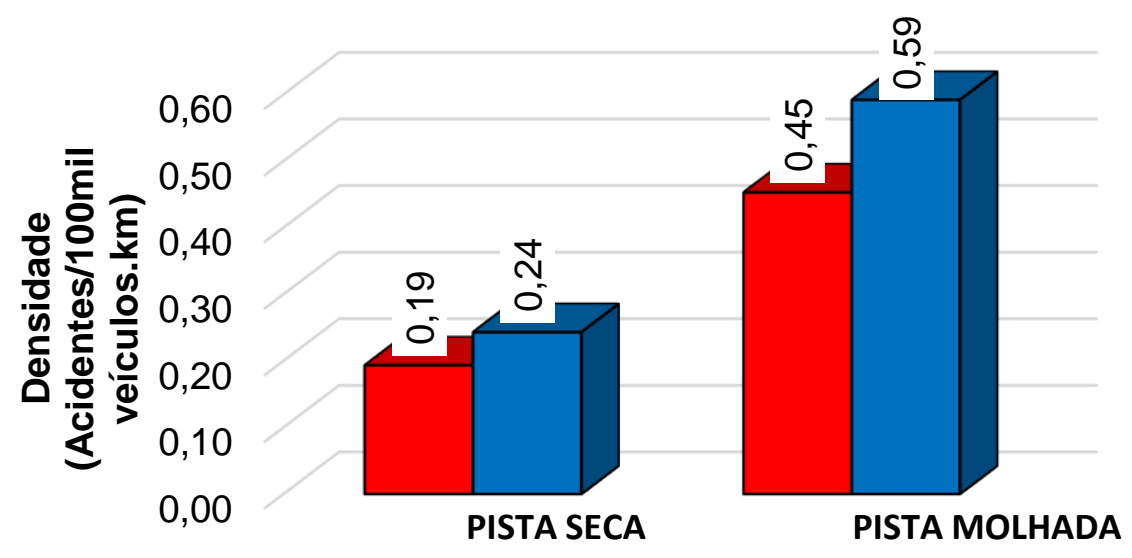

$\square$ Período de 4 anos antes da aplicação do TSD-AMB

$\square$ Período de 3 anos após a aplicação do TSD-AMB

Elaborada pelo Autor

Para o trecho em serra da pista sul, houve um aumento de $8,7 \%$ na densidade média de acidentes em pista seca e um aumento de 10,0\% em pista molhada. Em relação ao trecho em serra da pista norte, houve um aumento de $25,8 \%$ na densidade média de acidentes em pista seca e um aumento de 30,7\% em pista molhada. Estes dados contrastam com os resultados obtidos para os trechos experimentais, que apresentaram redução na densidade média de acidentes de 58,2\% em condições de pista seca e de 42,0\% em condições de pista molhada, no período após a aplicação do TSD-AMB.

Uma vez que os segmentos de referência possuem características similares aos trechos experimentais, como traçado sinuoso e superfície do pavimento com textura equivalente àquela existente antes da aplicação do TSD-AMB, pode-se considerar que a única diferença marcante entre estes segmentos foi a alteração da textura superficial do pavimento, com consequente aumento nos valores de atrito.

Observa-se que, se for descontada a porcentagem de variação observada para os segmentos de referência (que não passaram por nenhum tipo de intervenção visando a redução dos acidentes), os resultados obtidos para redução da densidade de acidentes para os trechos experimentais 1 e 2 se tornam ainda mais expressivas. 
Buscando uma validação estatística destas observações, os dados para estes segmentos de referência também foram utilizados para determinação da densidade mensal de acidentes desde o ano 2012.

A Figura 61 e a Figura 62 apresentam a evolução da densidade mensal de acidentes calculadas para os trechos em serra, considerados como segmentos de referência (desconsiderando os segmentos em TSD, bem como os 2 quilômetros posteriores, que serão considerados para análise da transferência dos acidentes).

Figura 61 - Evolução da densidade mensal de acidentes - Segmento de referência pista sul

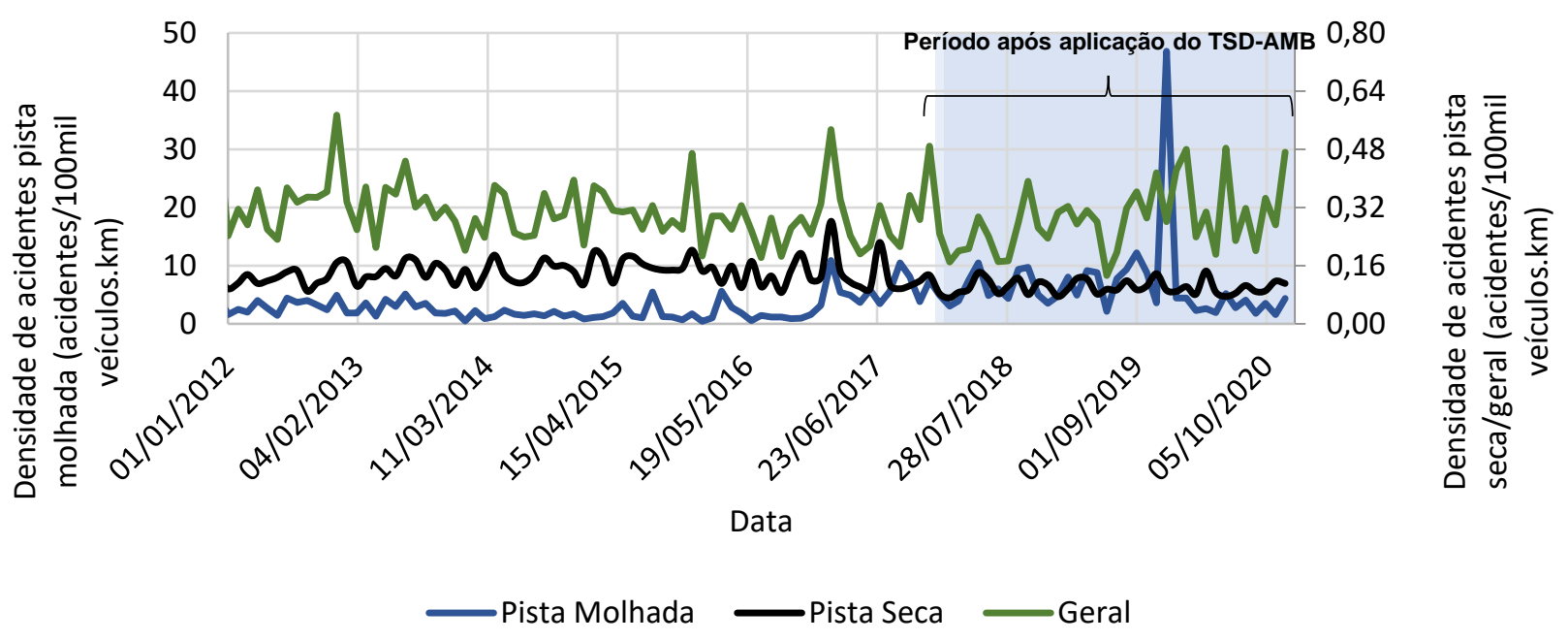

Elaborada pelo Autor 
Figura 62 - Evolução da densidade mensal de acidentes - Segmento de referência pista norte
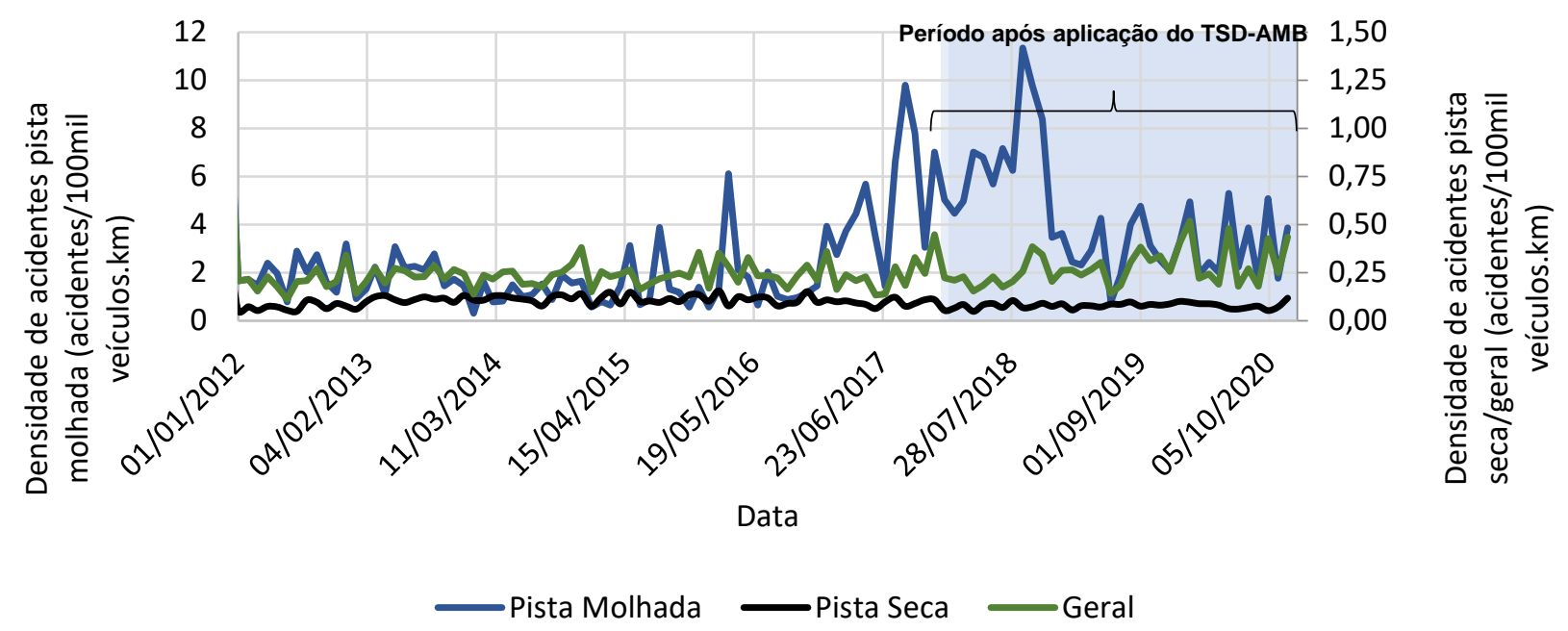

Elaborada pelo Autor

Observa-se que, para o segmento de referência da pista sul os valores apresentados não possuem diferença visualmente significativa ao longo do tempo, com exceção da densidade média de acidentes em pista molhada registrada para o mês de dezembro de 2019. Em relação ao segmento de referência da pista norte, observa-se uma maior variabilidade para os dados de densidade de acidentes também em condição de pista molhada. Da posse destes dados, foram criados histogramas para verificação da distribuição de probabilidade no período anterior e posterior à data de aplicação do TSD-AMB nos trechos experimentais, conforme Tabela 24. 
Tabela 24 - Histogramas para a densidade mensal de acidentes dos trechos em serra, considerados como segmentos de referência

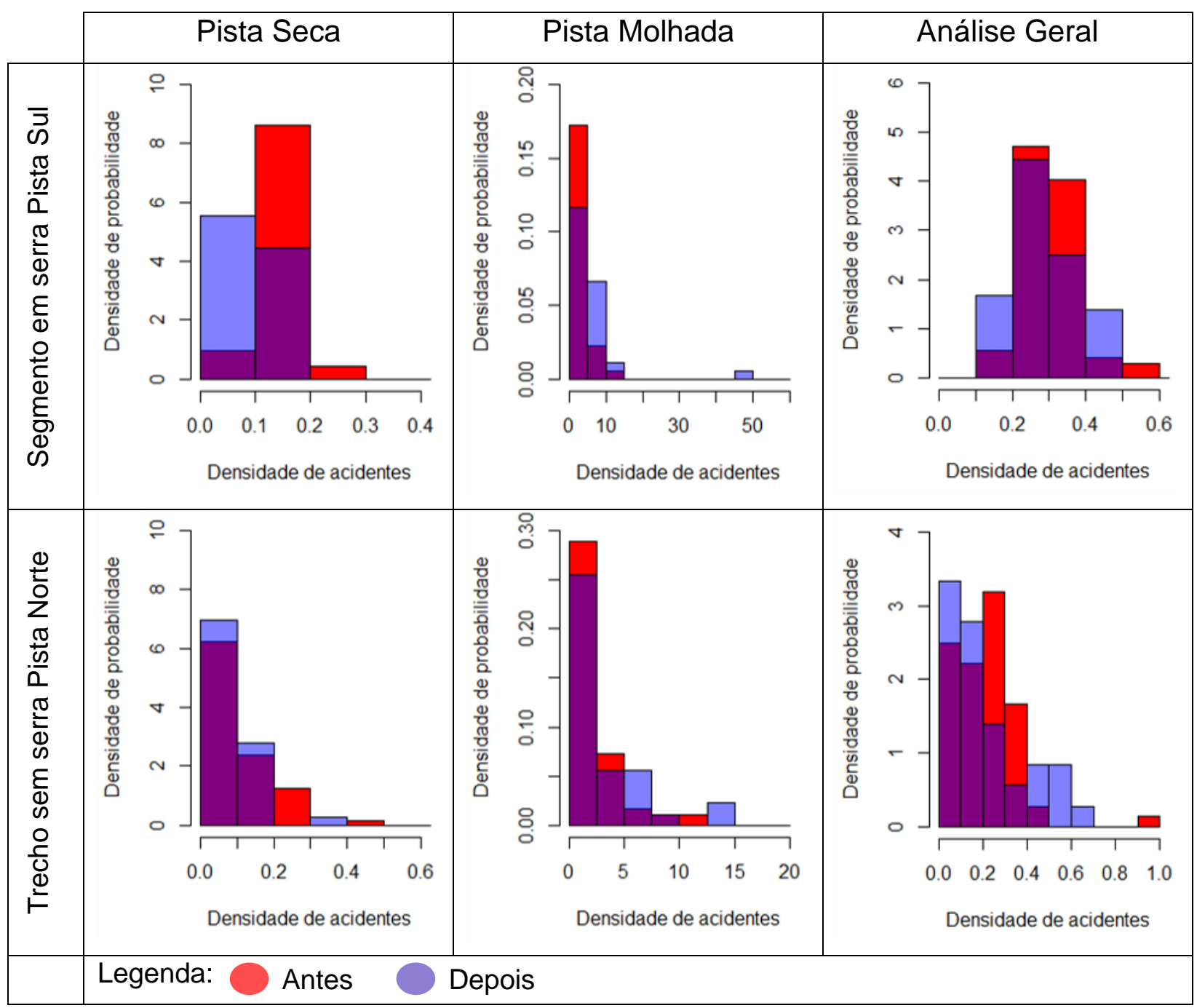

Elaborada pelo Autor

Observa-se que os dados, em geral, também não seguem uma distribuição normal, se assemelhando mais a uma distribuição exponencial, assim como foi observado para os trechos experimentais. Neste caso, não é possível constatar visualmente, com precisão, as diferenças entre as populações. De qualquer forma, procedeu-se a análise dos dados, através do software $\mathrm{R}$, com a realização do teste não paramétrico de Mann-Whitney (Wilcoxon rank sum test), para buscar evidências das diferenças entre os dados. A Tabela 25 apresenta os principais resultados obtidos. 
Tabela 25 - Resultados do teste de Mann-Whitney para comparação entre as densidades mensais dos segmentos de referência, antes e depois da data de aplicação do TSD-AMB.

\begin{tabular}{|c|c|c|c|c|c|c|c|}
\hline \multicolumn{8}{|c|}{$\begin{array}{l}\text { Análise estatística - Teste não paramétrico - Mann-Whitney (Wilcoxon rank sum test with continuity } \\
\text { correction) }\end{array}$} \\
\hline \multicolumn{2}{|c|}{$\begin{array}{l}2012 / 2017 \\
2018 / 2020\end{array}$} & \multicolumn{2}{|c|}{ Pista Seca } & \multicolumn{2}{|c|}{ Pista Molhada } & \multicolumn{2}{|c|}{ Geral } \\
\hline \multirow{3}{*}{$\begin{array}{l}\text { Trecho em serra - } \\
\quad \text { Pista Sul }\end{array}$} & Valor $\mathbf{p}$ & \multicolumn{2}{|c|}{ 3,47E-09 } & \multicolumn{2}{|c|}{$1,28 \mathrm{E}-07$} & \multicolumn{2}{|c|}{$3,11 \mathrm{E}-01$} \\
\hline & $\begin{array}{l}\text { Difference in } \\
\text { location }\end{array}$ & \multicolumn{2}{|c|}{$-0,04$} & \multicolumn{2}{|c|}{3,02} & \multicolumn{2}{|c|}{$-0,02$} \\
\hline & Cl $90 \%$ & $-0,05$ & $-0,03$ & 2,09 & 3,78 & $-0,05$ & 0,01 \\
\hline \multirow{3}{*}{$\begin{array}{l}\text { Trecho em serra - } \\
\text { Pista Norte }\end{array}$} & Valor $p$ & \multicolumn{2}{|c|}{ 1,69E-09 } & \multicolumn{2}{|c|}{$2,96 \mathrm{E}-07$} & \multicolumn{2}{|c|}{ 1,33E-01 } \\
\hline & $\begin{array}{l}\text { Difference in } \\
\text { location }\end{array}$ & \multicolumn{2}{|c|}{$-0,04$} & \multicolumn{2}{|c|}{2,58} & \multicolumn{2}{|c|}{$-0,02$} \\
\hline & Cl $90 \%$ & $-0,05$ & $-0,03$ & 1,76 & 3,30 & $-0,05$ & $4,10 \mathrm{E}-03$ \\
\hline
\end{tabular}

Elaborada pelo Autor

É possível observar que, na análise geral dos dados, não existem evidências, ao nível de significância de $10 \%$, de que há alguma diferença entre as populações para os períodos antes e depois, tendo em vista que o valor $p$ foi superior a 0,10 , tanto para o trecho em serra na pista sul quanto para o trecho em serra na pista norte. Este fato pode ser observado também através da verificação da oscilação entre valores negativos e positivos do Intervalo de Confiança de $90 \%$ para o parâmetro Difference in Location, que, conforme explicado anteriormente, representa a mediana dos desvios entre os dados de densidade de acidentes utilizados na análise estatística. Nota-se que para a condição de pista seca, existem evidências de que houve uma redução da mediana da densidade de acidentes, sendo esta redução igual para os dois segmentos de referência, ao passo que, para condições de pista molhada, existe evidências de que a mediana da densidade de acidentes aumentou consideravelmente.

Novamente, ressalta-se que para os trechos experimentais, onde houve aplicação do TSD-AMB, foi evidenciada a redução da densidade de acidentes em condições de pista molhada, contratando com os segmentos de referência, que sofreram um aumento desta densidade no mesmo período de análise. 


\subsection{Avaliação da transferência de acidentes para segmentos posteriores}

Uma vez que o tratamento de segmentos críticos pode levar à percepção de maior segurança por parte dos motoristas, existe uma alta probabilidade desta percepção influenciar em seu comportamento, principalmente no que diz respeito à direção defensiva. Este fato pode fazer com que exista um comportamento mais agressivo nos segmentos posteriores, causando a transferência dos acidentes para segmentos onde não havia elevada criticidade até então.

De forma a avaliar se houve a transferência dos acidentes, foi calculada a densidade média de acidentes para os segmentos de 2 quilômetros após o final das soluções aplicadas nos trechos experimentais, considerando o período de 4 anos antes e 3 anos após a aplicação do TSD-AMB. Os resultados obtidos são apresentados na Figura 63 e Figura 64, para o segmento após o trecho experimental 1 e para o segmento após o trecho experimental 2 , respectivamente.

Figura 63 - Avaliação da densidade média de acidentes para o segmento de 2 quilômetros após o trecho experimental 1

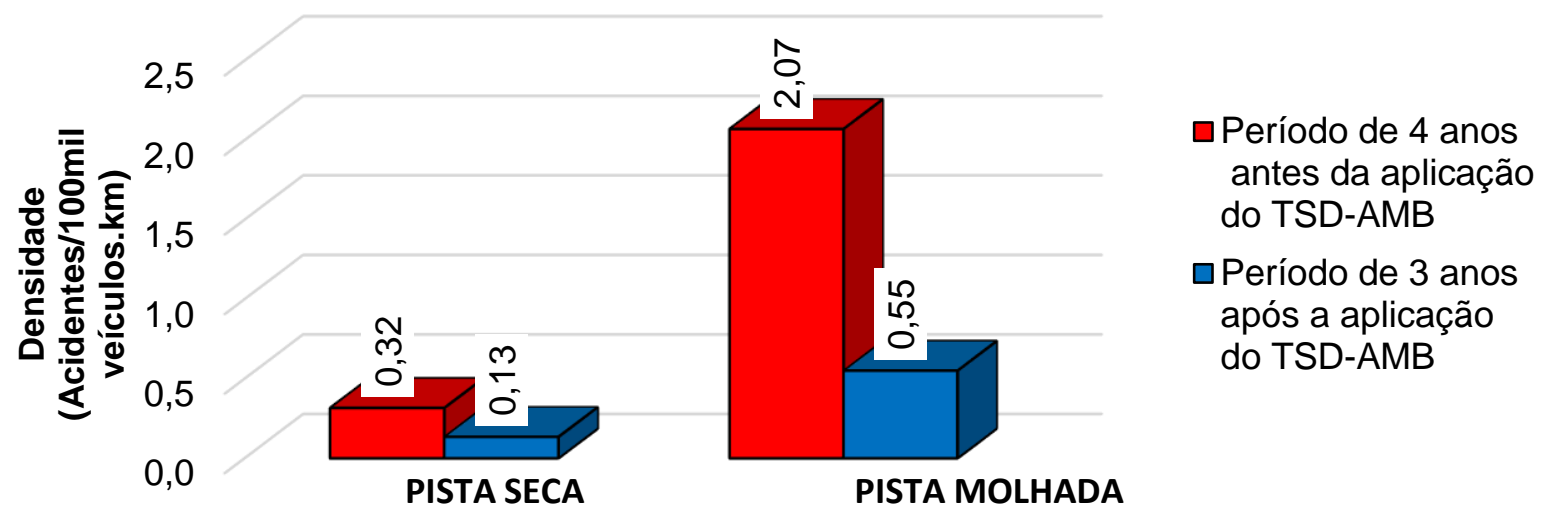

Elaborada pelo Autor 
Figura 64 - Avaliação da densidade média de acidentes para o segmento de 2 quilômetros após o trecho experimental 2

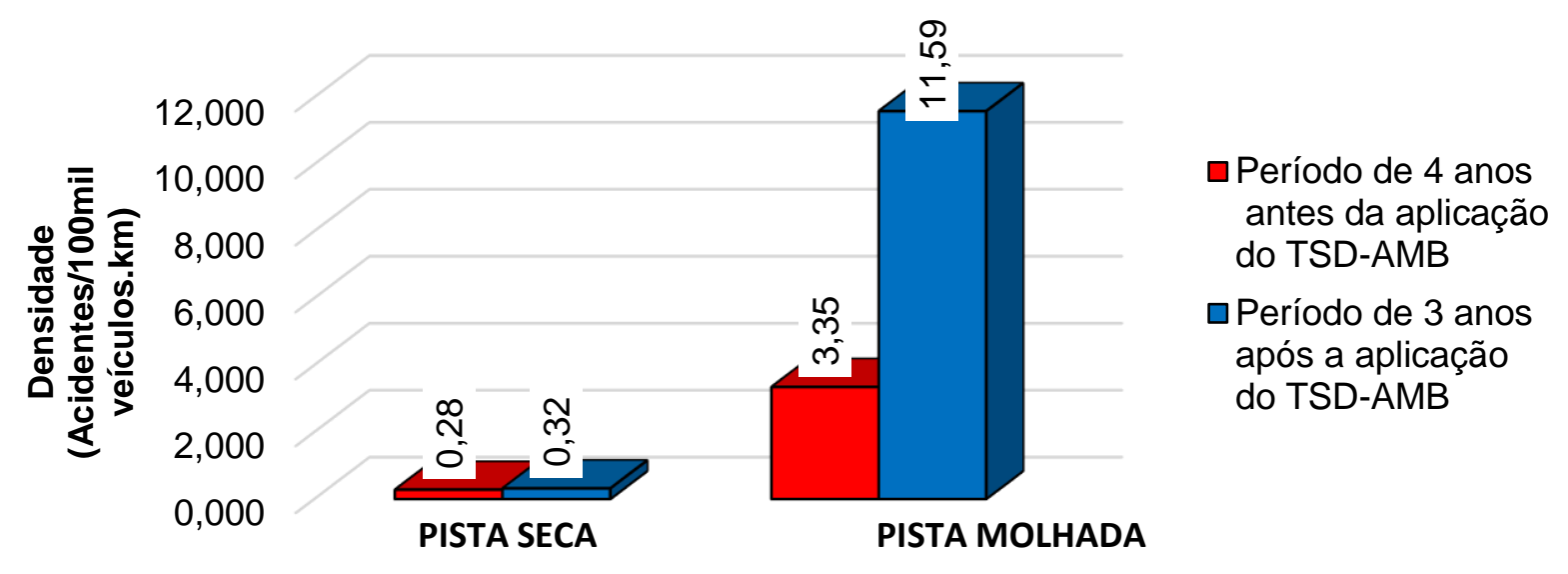

Elaborada pelo Autor

É possível observar que a densidade de acidentes para os 2 quilômetros posteriores à aplicação do TSD-AMB no trecho experimental 1 também foi reduzida, tanto para pista seca (redução de 57,5\%) quanto para pista molhada (redução de $73,4 \%$ ). Pode-se afirmar que para este segmento específico, não houve transferência dos acidentes. Este fato pode ser justificado pela característica geométrica deste segmento, que possui a maior parte de sua extensão em aclive, e não possui quantidade relevante de curvas de pequeno raio e de curvas reversas (Figura 65). Da mesma forma que não se pode afirmar que houve transferência dos acidentes do trecho experimental 1 para este segmento, também não se pode afirmar que a redução obtida neste ponto possui alguma relação com o tratamento, uma vez que a flutuação natural da quantidade de acidentes por ano se torna muito sensível para trechos com baixa densidade de acidentes (AASHTO, 2010). 
Figura 65 - Segmento de 2 quilômetros após o trecho experimental 1

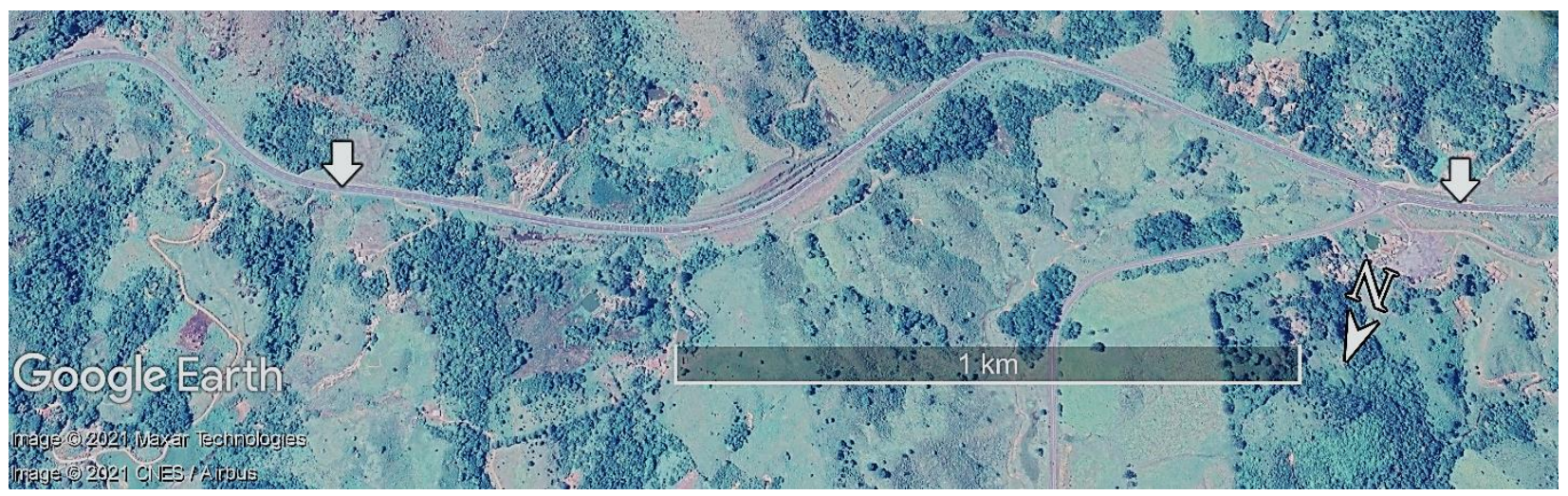

Fonte: Elaborada pelo Autor utilizando a ferramenta Google Maps

Em relação ao segmento de 2 quilômetros posterior à aplicação do TSD-AMB no trecho experimental 2, nota-se que, no período de 3 anos após a conclusão da obra, houve um aumento de $14,1 \%$ na densidade de acidentes em pista seca, e houve um aumento de $246,1 \%$ na densidade de acidentes em pista molhada. Uma vez que este segmento também não apresenta quantidade relevante de curvas de pequeno raio e curvas reversas (Figura 66), é possível que exista alguma deficiência geométrica neste segmento, com provável deficiência na superelevação, tendo em vista que os valores históricos de macrotextura para este segmento, conforme relatórios anuais entregues pela concessionária desde 2017 até 2020, apresentam um valor de macrotextura estimado em função do Intervalo de Confiança de $95 \%$ entre $0,71 \mathrm{~mm}$ e $0,82 \mathrm{~mm}$. 
Figura 66 - Segmento de 2 quilômetros após o trecho experimental 2

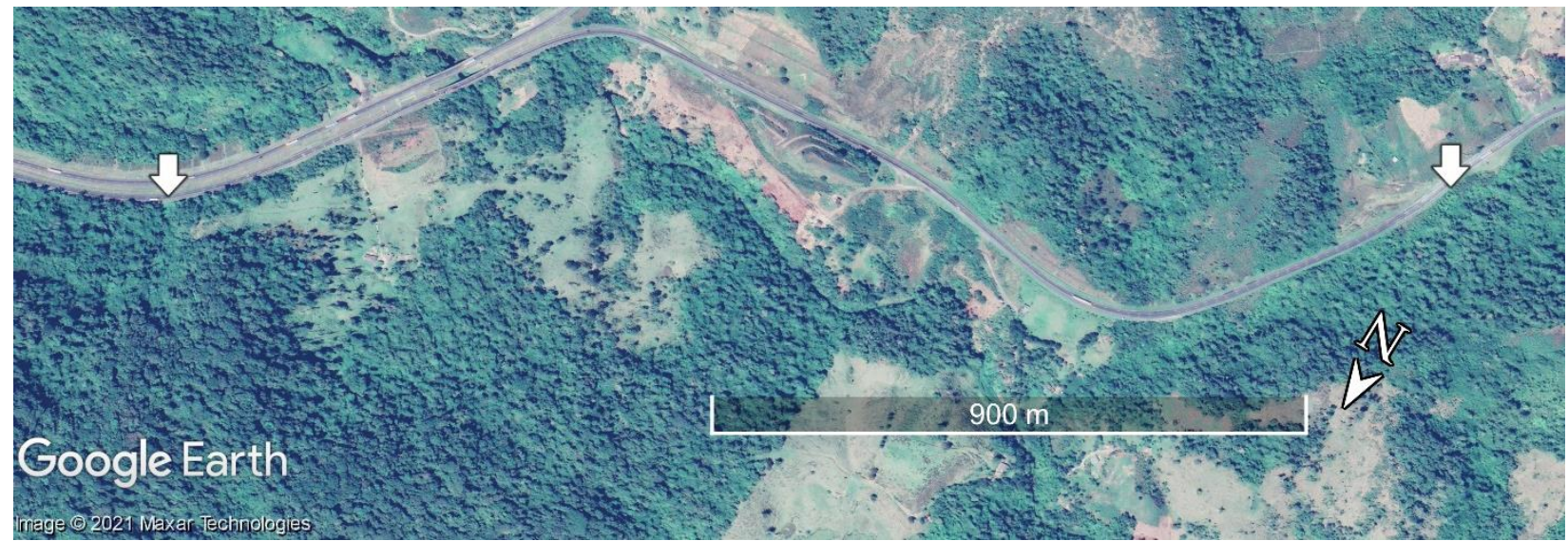

Fonte: Elaborada pelo Autor utilizando a ferramenta Google Maps

De forma a evidenciar estatisticamente estas afirmativas, os dados para estes segmentos utilizados como base para análise da transferência dos acidentes também foram utilizados para determinação da densidade mensal de acidentes desde o ano 2012. A Figura 67 e a Figura 68 apresentam a evolução da densidade mensal de acidentes calculadas para estes segmentos.

Figura 67 - Evolução da densidade mensal de acidentes - Segmento passíveis de transferência de acidentes para o trecho experimental 1
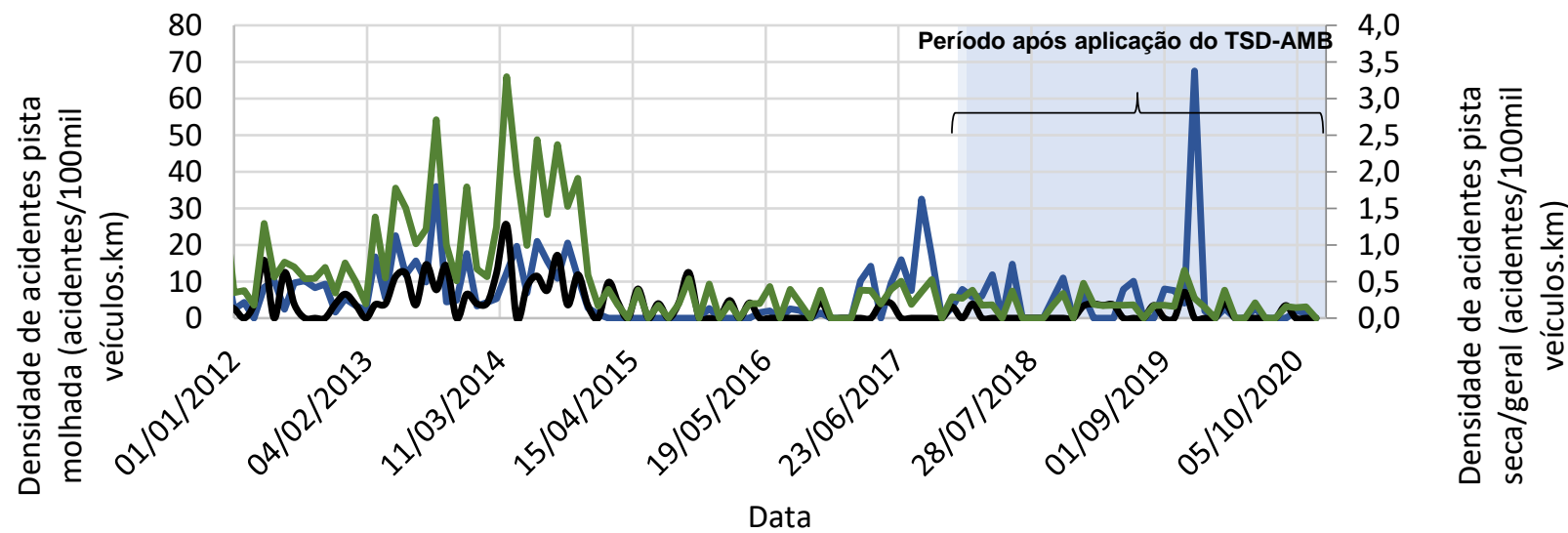

- Pista Molhada — Pista Seca Geral

Elaborada pelo Autor 
Figura 68 - Evolução da densidade mensal de acidentes - Segmento passíveis de transferência de acidentes para o trecho experimental 2

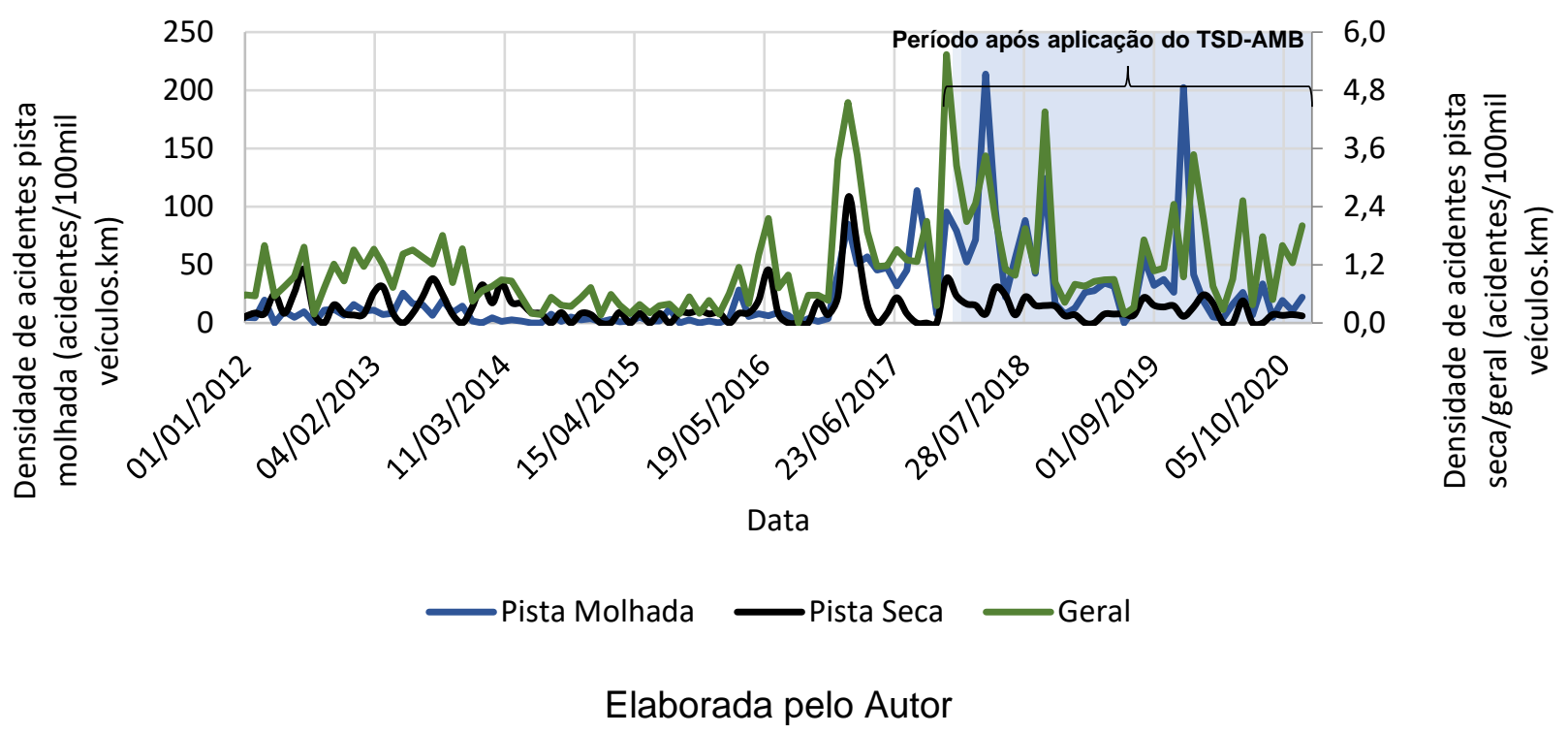

Em relação ao segmento passível de transferência de acidentes relativo ao trecho experimental 1, não se observa um aumento na densidade média de acidentes mensal após a data de aplicação do TSD-AMB. Nota-se que o mês de dezembro de 2019 foi um mês atípico, onde ocorreu a maior densidade de acidentes em condição de pista molhada. Já em relação ao segmento passível de transferência de acidentes relativo ao trecho experimental 2, observa-se um aumento considerável na densidade mensal de acidentes em pista molhada, o que levou consequentemente a um aumento na densidade de acidentes geral (sem separação entre pista seca e molhada). Através da análise da Figura 68, é possível observar que este aumento começou a ocorrer alguns meses antes da aplicação do TSD-AMB nos segmentos experimentais (mais precisamente em fevereiro de 2017), indicando que houve algum outro fator de contribuição para este aumento, não podendo ser afirmado indubitavelmente que o tratamento do segmento posterior com o TSD-AMB ocasionou a transferência dos acidentes.

A Tabela 26 apresenta o histograma desenvolvido com estes dados para as diversas condições de análise. 
Tabela 26 - Histogramas para a densidade mensal de acidentes dos segmentos passíveis de transferência de acidentes

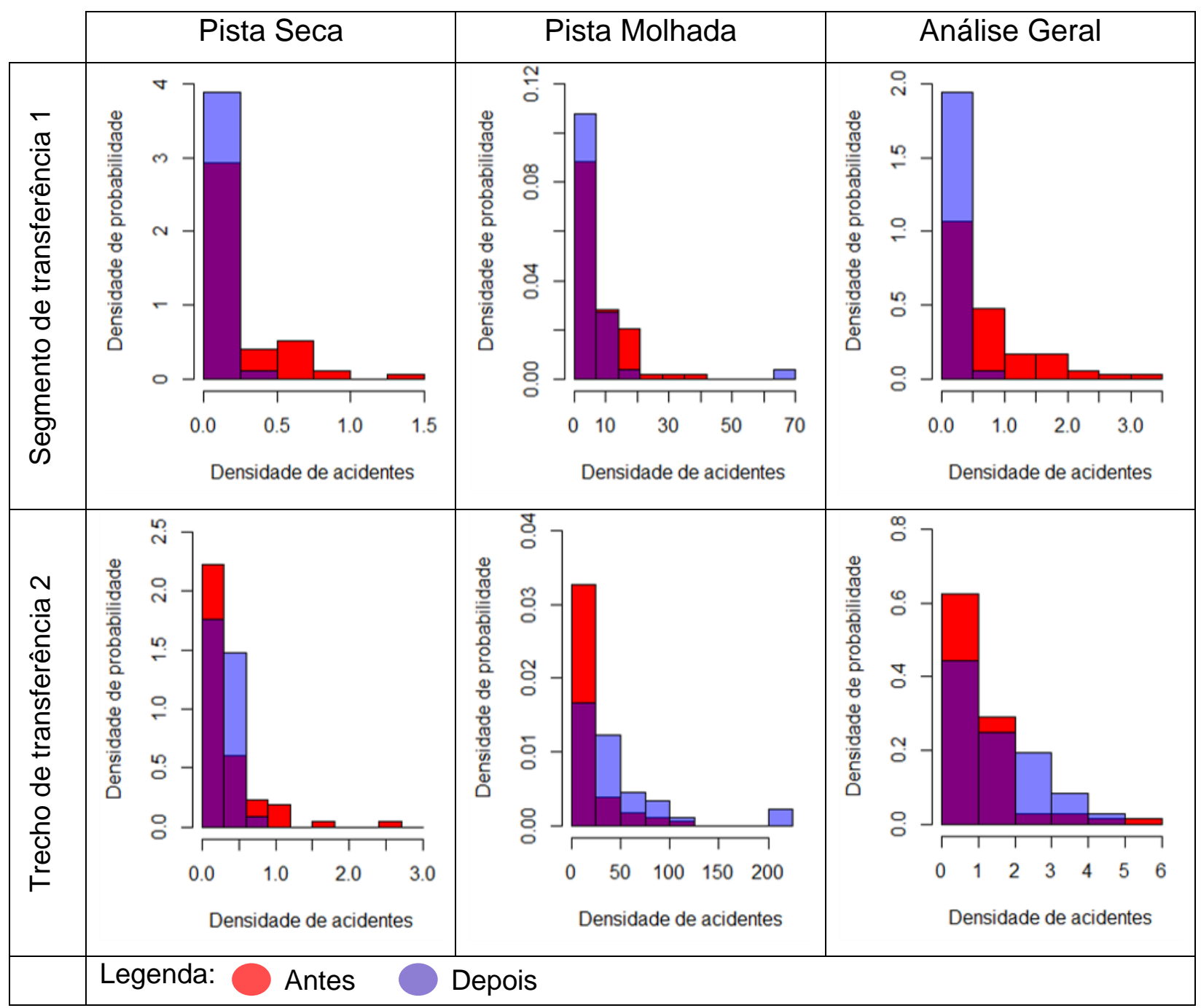

Elaborada pelo Autor

Observa-se novamente que, para todas as condições de análise, as populações do período antes e após aplicação do TSD-AMB nos trechos experimentais são diferentes. Para o segmento de transferência 1, observa-se que a distribuição de probabilidade para a densidade de acidentes se aproximou ao eixo y, indicando redução na densidade de acidentes no período. Em relação ao segmento de transferência 2, notase que para as condições de pista molhada e para condições gerais, houve um aumento 
na quantidade de observações mais distantes do eixo $\mathrm{y}$, indicando um aumento na densidade de acidentes.

Estes valores foram analisados através do teste estatístico não paramétrico de Maan-Whitney (Wilcoxon rank sum test), e os resultados são apresentados na Tabela 27.

Tabela 27 - Resultados do teste de Mann-Whitney para comparação entre as densidades mensais dos segmentos passíveis de transferência de acidentes, antes e depois da data de aplicação do TSD-AMB

\begin{tabular}{|c|c|c|c|c|c|c|c|}
\hline \multicolumn{8}{|c|}{$\begin{array}{l}\text { Análise estatística - Teste não paramétrico - Mann-Whitney (Wilcoxon rank sum test with continuity } \\
\text { correction) }\end{array}$} \\
\hline $\begin{array}{l}2012 / 2017 \\
2018 / 202 C\end{array}$ & & \multicolumn{2}{|c|}{ Pista Seca } & \multicolumn{2}{|c|}{ Pista Molhada } & \multicolumn{2}{|c|}{ Geral } \\
\hline \multirow{3}{*}{$\begin{array}{l}\text { Transferência Trecho } \\
\text { Experimental } 1 \text { - } 2 \mathrm{KM}\end{array}$} & Valor $p$ & \multicolumn{2}{|c|}{$4,61 \mathrm{E}-04$} & \multicolumn{2}{|c|}{$7,02 \mathrm{E}-02$} & \multicolumn{2}{|c|}{$1,16 \mathrm{E}-06$} \\
\hline & $\begin{array}{l}\text { Difference in } \\
\text { location }\end{array}$ & \multicolumn{2}{|c|}{$-0,02$} & \multicolumn{2}{|c|}{$-1,34$} & \multicolumn{2}{|c|}{$-0,29$} \\
\hline & $\mathrm{Cl} 90 \%$ & $-0,18$ & 0,00 & $-2,75$ & 0,00 & $-0,39$ & $-0,19$ \\
\hline \multirow{3}{*}{$\begin{array}{l}\text { Transferência Trecho } \\
\text { Experimental } 2 \text { - } 2 \mathrm{KM}\end{array}$} & Valor $p$ & \multicolumn{2}{|c|}{$6,68 \mathrm{E}-01$} & \multicolumn{2}{|c|}{$1,04 \mathrm{E}-06$} & \multicolumn{2}{|c|}{$4,82 \mathrm{E}-03$} \\
\hline & $\begin{array}{l}\text { Difference in } \\
\text { location }\end{array}$ & \multicolumn{2}{|c|}{0,00} & \multicolumn{2}{|c|}{18,54} & \multicolumn{2}{|c|}{0,42} \\
\hline & $\mathrm{Cl} 90 \%$ & $-0,04$ & 0,13 & 11,93 & 25,31 & 0,19 & 0,66 \\
\hline
\end{tabular}

Observa-se que, dentre as diversas condições de análise, não existem evidências suficientes para se confirmar uma alteração entre as densidades de acidentes antes e após a data de aplicação do TSD-AMB apenas para a condição de pista seca, no segmento de transferência relativo ao trecho experimental 2, tendo em vista a obtenção de um valor $p$ superior a 0,1 . Nos demais casos, o valor $p$ obtido foi inferior a 0,1 , indicando que existem evidências suficientes, a um nível de significância de 10\%, de que houve alteração nas densidades de acidentes ao se comparar os dois períodos de análise. Destaca-se, neste caso, o grande aumento observado para o segmento de transferência relativo ao trecho experimental 2 , em condições de pista molhada. De qualquer forma, conforme observado na Figura 68, o início da tendência de aumento na densidade de acidentes em pista seca para este caso começou a ser observado em 
fevereiro de 2017, indicando que esta variação de densidade não pode ser atribuída exclusivamente ao tratamento realizado com o TSD-AMB nos trechos experimentais. 


\section{CONSIDERAÇÕES FINAIS}

\subsection{CONCLUSÕES}

Esta pesquisa teve por objetivo avaliar a possibilidade de redução de acidentes rodoviários por derrapagem em segmentos críticos de rodovias, principalmente aqueles ocorridos em condição de pavimento molhado, através do aumento da macrotextura superficial dos pavimentos e aumento do atrito. Para isto, empregou-se uma técnica inovadora para rodovias de tráfego pesado, sendo ela a execução de um Tratamento Superficial Duplo, com asfalto modificado por borracha moída de pneus inservíveis. Foram tratados dois segmentos críticos da rodovia BR-116, no trecho sob administração da concessionária Autopista Régis Bittencourt, compreendido entre as cidades de São Paulo - SP e Curitiba - PR. A seguir são apresentadas as principais conclusões obtidas:

- O levantamento de dados é uma etapa fundamental para possibilitar a realização de estudos precisos relativos às condições de segurança viária. É imprescindível que os dados possuam a quantidade máxima possível de detalhamento, de forma que os gestores das rodovias possam identificar de maneira precisa os segmentos de maior concentração de acidentes, e também as causas destes acidentes, para que sejam tomadas atitudes adequadas para redução dos acidentes, de forma a otimizar o emprego de recursos e garantir a eficiência das soluções empregadas.

- Foi possível observar que a ocorrência de acidentes por derrapagem se relaciona de maneira direta com a criticidade dos segmentos sinuosos de rodovias, compostos por curvas de pequeno raio de curvatura e por sequências de curvas reversas, que favorecem a ocorrência da hidroplanagem devido à existência de região com superelevação igual a zero, que contribui para a deficiência de drenagem superficial das águas de chuva.

- Para os segmentos de rodovias com grande concentração de acidentes por derrapagem, principalmente em condições chuvosas, o aumento da macrotextura do pavimento se mostrou uma boa alternativa para redução destas ocorrências, tendo em vista que facilita o escoamento superficial da 
água, sem que haja redução do contato entre agregados e pneus, garantindo a existência de atrito suficiente para controle direcional dos veículos inclusive na realização de manobras evasivas emergenciais.

- O Tratamento Superficial Duplo com asfalto modificado por borracha (TSDAMB) garantiu elevados valores de profundidade média de macrotextura para os segmentos tratados ao longo dos três anos de análise considerados neste estudo (entre a $1,58 \mathrm{~mm}$ e 2,01 mm, considerando Intervalo de confiança de $95 \%$ ). De qualquer forma, não se pode negligenciar o desgaste natural desta camada ao longo do tempo, que ocorre através do desprendimento de agregados da camada superficial, expondo a camada inferior com agregados de maior dimensão. Este fato pode ser amenizado através da aplicação de uma capa selante sobre a camada de TSD-AMB, ao menos um ano após a liberação ao tráfego, iniciativa que não foi realizada nos trechos em questão, mas que se considera importante de ser realizada. De qualquer forma, para garantia da durabilidade do TSD-AMB, é fundamental que sejam seguidas as melhores práticas de dosagem, a escolha adequada dos materiais, além do controle efetivo de aplicação desta camada em pista. Ressalta-se que o TSD-AMB é uma camada de desgaste, não devendo ser considerada para fins estruturais. Por ser uma camada de baixa espessura, ela replica a condição de irregularidade longitudinal pré-existente. A existência de defeitos no substrato, como falhas de drenagem que acarretam o fenômeno de bombeamento de finos, podem causar a redução drástica de sua vida útil, portanto, para segmentos a serem tratados com aplicação do TSD-AMB, se faz necessária a correção prévia dos defeitos existentes no pavimento.

- Ao se realizar o tratamento de segmentos críticos, seja por alteração do atrito, ou por implantação de outras alternativas como a instalação de radares para redução de velocidade, deve-se sempre estudar a possibilidade de transferência dos acidentes para segmentos posteriores, de forma a garantir uma redução efetiva destas terríveis ocorrências na rodovia como um todo.

- No Brasil, a altura média da macrotextura para pavimentos rodoviários deve estar situada entre $0,6 \mathrm{~mm}$ e $1,2 \mathrm{~mm}$, de acordo com as especificações 
elaboradas pelos órgãos governamentais. Entretanto, conforme comprovado neste estudo, o emprego de camada asfáltica com macrotextura média superior a 1,58 mm pode reduzir consideravelmente os acidentes, uma vez que, ao se analisar os dados dos 2 trechos experimentais construídos e monitorados por 3 anos, a redução média na densidade de acidentes obtida em condições de pista seca foi de $58,2 \%$ (57,0\% para o trecho experimental 1 e $58,5 \%$ para o trecho experimental 2), e a redução média na densidade de acidentes obtida em condições de pista molhada foi de 42,0\% (37,1\% para o trecho experimental 1 e $43,6 \%$ para o trecho experimental 2), sendo estes dados validados estatisticamente. Sendo assim, pode-se afirmar que a utilização de soluções de pavimento com valores de macrotextura superiores a 1,2 $\mathrm{mm}$ pode auxiliar na preservação de vidas. Portanto, a fixação de um valor máximo aceitável de macrotextura, estabelecida buscando a limitação da geração de ruído e do desgaste dos pneus dos veículos, torna-se um critério equivocado, considerando que estes fenômenos são muito complexos e não dependem exclusivamente da altura desta macrotextura, e sim se ela é positiva ou negativa. Salienta-se que o estabelecimento de um limite máximo, por muitas vezes, pode limitar consideravelmente a eficiência de ações para redução de acidentes.

\subsection{SUGESTÕES PARA ESTUDOS FUTUROS}

O presente trabalho demonstrou como a melhoria das condições de macrotextura e de atrito superficial dos pavimentos pode auxiliar na redução da densidade média de acidentes em trechos sinuosos de rodovias. Durante o desenvolvimento desta pesquisa, foram observadas algumas questões adicionais de grande relevância, que podem ser objeto de estudos futuros, a saber:

- Definição de critérios para aceitação de soluções de pavimento com valores de profundidade média de macrotextura superiores a $1,2 \mathrm{~mm}$, levando em 
consideração critérios como criticidade do segmento e características pluviométricas regionais.

- Avaliação do provável ganho de vida útil para camadas de TSD aplicadas em segmentos sinuosos, com curvas de pequeno raio e elevada solicitação de atrito lateral devido ao tráfego intenso de veículos pesados, através da aplicação de capa selante, visando a redução da desagregação.

- Estudo da viabilidade e efetividade da instalação de radares, bem como sinalização vertical e horizontal específicas, em pontos distribuídos ao longo dos segmentos de maior criticidade das rodovias. 


\section{REFERÊNCIAS}

AASHTO. A Policy on Geometric Design of Highways and Streets (Green Book 2011). 6th ed. Washington, D.C.: American Association of State Highway and Transportation Officials, 2018.

Highway safety manual, Washington, DC. 2010.

AL-MASAEID, H R. Impact of pavement condition on rural road accidents. Canadian Journal of Civil Engineering, [s.l.], v. 24, n. 4, p.523-531, ago. 1997. Canadian Science Publishing. http://dx.doi.org/10.1139/197-009.

AMERICAN SOCIETY FOR TESTING AND MATERIALS. E1710: Standard Test Method for Measurement of Retroreflective Pavement Marking Materials with CEN-Prescribed Geometry Using a Portable Retroreflectometer. West Conshohocken: ASTM, 2018.

. E1845 - 15. Standard Practice for Calculating Pavement Macrotexture Mean Profile Depth. West Conshohocken, Pennsylvania, United States: American Society for Testing and Materials, 2015

E965 - 15. Standard Test Method for Measuring Pavement Macrotexture Depth Using a Volumetric Technique. West Conshohocken, Pennsylvania, United States: American Society for Testing and Materials, 2015.

APS, Marcia. Classificação da aderência pneu-pavimento pelo índice combinado IFI - International Friction Index para revestimentos asfálticos. 2006. $179 \mathrm{f}$. Tese (Doutorado) - Curso de Engenharia Civil, Universidade de São Paulo, São Paulo, 2006.

ARAKAWA, Maki. Contribuição ao estabelecimento do comprimento desejável da espiral de transição em rodovias rurais e urbanas. 2013. $132 \mathrm{f}$. Dissertação (Mestrado) - Curso de Engenharia Civil, Universidade de São Paulo, São Paulo, 2013.

ARTERIS (São Paulo). Soluções para a redução de acidentes por derrapagem em pista molhada através da textura superficial dos pavimentos. Registro: Autopista Régis Bittencourt, 2019.

ASPHALT INSTITUTE (Estados Unidos). The asphalt handbook. 7. ed. Lexington: Asphalt Institute, 2010. 788 p.

ASSOCIAÇÃO BRASILEIRA DE NORMAS TÉCNICAS. NBR 10697: Pesquisa de acidentes de trânsito - terminologia. 2 ed. Rio de Janeiro: ABNT, 2018.

NBR 11341: Derivados de petróleo - Determinação dos pontos de fulgor e de combustão em vaso aberto Cleveland. Rio de Janeiro: ABNT, 2014. 
. NBR 14723: Sinalização horizontal viária - avaliação da retrorrefletividade utilizando equipamento manual com geometria de 15 m. Rio de Janeiro: ABNT, 2013.

. NBR 15529: Asfalto borracha - propriedades reológicas de materiais não newtonianos por viscosímetro rotacional. Rio de Janeiro: ABNT, 2007.

. NBR 6296: Produtos betuminosos semissólidos — determinação da massa específica e densidade relativa. Rio de Janeiro: ABNT, 2012.

. NBR 6560: Ligantes asfálticos - determinação do ponto de amolecimento método do anel e bola. Rio de Janeiro: ABNT, 2016.

. NBR 6576: Materiais asfálticos - determinação da penetração. Rio de Janeiro: ABNT, 2007.

. NBR NM 51: Agregado graúdo - Ensaio de abrasão "Los Angeles". Rio de Janeiro: ABNT, 2001.

Berning, A., Compton, R., \& Wochinger, K. Results of the 2013-2014 National Roadside Survey of Alcohol And Drug Use By Drivers. (Traffic Safety Facts Research Note. Report No. DOT HS 812 118). Washington, DC: National Highway Traffic and Safety Administratio, 2015.

BERNUCCI, Liedi Legi Bariani et al. Pavimentação Asfáltica: Formação Básica para Engenheiros. Rio de Janeiro: Abeda, 2010.

Blomberg, R. D., Peck, R. C., Moskowitz, H., Burns, M. \& Fiorentino, D. (2005). Crash Risk of Alcohol Involved Driving: A Case-Control Study, Final Report to the National Highway Traffic Safety Administration. Stamford, CT: Dunlap and Associates, Inc.

BOGSTRAND, Stig Tore et al. Alcohol, psychoactive substances and non-fatal road traffic accidents - a case-control study. Bmc Public Health, [s.l.], v. 12, n. 1, p.63-70, 3 set. 2012. Springer Nature. Http://dx.doi.org/10.1186/1471-2458-12-734.

Borkenstein, R. F., Crowther, R. F., Shumate, R. P., Ziel, W. B., and Zylman, R. The Role of the Drinking Driver in Traffic Accidents. Bloomington, Indiana: Indiana University, Department of Police Administration, 1964.

BRASIL. Lei no 9503, de 23 de setembro de 1997. Brasília, DF.

BUCHARLES, Luciano Gardano Elias. Critérios para avaliação pericial da macro e microtextura de pavimento asfáltico em local de acidente de trânsito. 2014. $153 \mathrm{f}$. Tese (Doutorado) - Curso de Engenharia Civil, Universidade de São Paulo, São Carlos, 2014. 
CALLAI, Sérgio Copetti. Estudo do ruído causado pelo tráfego de veículos em rodovias com diferentes tipos de revestimentos de pavimentos. 2011. $92 \mathrm{f}$.

Dissertação (Mestrado) - Curso de Engenharia Civil, Universidade de São Paulo, São Paulo, 2011.

CARVALHO, F. S. Análise da textura superficial de pavimentos asfálticos sua influência na ocorrência de acidentes de tráfego rodoviário em condição de pista molhada. São Paulo: Dissertação: (Mestrado). Escola Politécnica da Universidade de São Paulo, 2019.

Carvalho, M. S.; câmara, G. Análise de Eventos Pontuais. In Druck, S.; Carvalho, M. S.; Câmara, G.; Monteiro, A. V. M. (editores) "Análise Espacial de Dados Geográficos". Brasília, EMBRAPA, Capítulo 2, 2004

CONFEDERAÇÃO NACIONAL DO TRANSPORTE. (2017). Pesquisa CNT de rodovias 2017: Relatório gerencial. Brasília: CNT: SEST: SENAT. 403p

DAWSON, Drew et al. Determining the likelihood that fatigue was present in a road accident: $A$ theoretical review and suggested accident taxonomy. Sleep Medicine Reviews, [s.I.], v. 42, p.202-210, dez. 2018. Elsevier BV. http://dx.doi.org/10.1016/j.smrv.2018.08.006.

DEPARTAMENTO AUTÔNOMO DE ESTRADAS DE RODAGEM. DAER/RS-EL 108/01: Determinação do índice de lamelaridade. Porto Alegre: DAER/RS, 2001.

DEPARTAMENTO DE ESTRADAS DE RODAGEM. DER-SP. NT-DE-F00/001: NOTAS TÉCNICAS DE PROJETO GEOMÉTRICO. São Paulo: Secretaria dos Transportes, 2006.

DEPARTAMENTO DE INFRAESTRUTURA DO ESTADO DE SANTA CATARINA. DEINFRA-SC ES - $P$ 12/16: Tratamentos superficiais asfálticos por penetração a quente. Florianópolis: DEINFRA-SC (dpla), 2016.

DNER. Manual De Projeto Geométrico De Rodovias Rurais. Rio de Janeiro: Departamento Nacional de Estradas de Rodagem, Diretoria de Desenvolvimento Tecnológico, divisão de Capacitação Tecnológica, 1999. 195p.

DNIT - Departamento Nacional de Infraestrutura de Transportes. Manual de restauração de pavimentos asfálticos. Rio de Janeiro: IPR, 2006 2010. 392p.

Manual de Projeto Geométrico de Travessias Urbanas. Rio de Janeiro,

EMEASOBA, U. R. B.; OGBUEFI, J. U. Sustainable socio-economic development in Nigeria: a case for road infrastructure maintenance. Journal of Environment and Earth Science, vol. 3, № 5, 2013, p. 129-137. 
FARIAS, Raíssa Rodrigues Cardoso de. Estudo da aderência pneu-pavimento em revestimentos asfálticos e sua influência na ocorrência de acidentes viários em condições de pista molhada. $110 \mathrm{f}$. Exame de qualificação (Mestrado) - Curso de Engenharia de Transportes, Universidade de São Paulo, São Paulo, 2021.

FERRAZ, Coca et al. Segurança viária. São Carlos: Suprema Gráfica e Editora, 2012.

FERREIRA, Jorge Luis Santos. Novas diretrizes para seleção granulométrica de misturas asfálticas densas com foco na deformação permanente. 2017. $62 \mathrm{f}$. Dissertação (Mestrado) - Curso de Engenharia Civil, Departamento de Engenharia de Transportes, Universidade Federal do Ceará, Fortaleza, 2017.

FHWA - Federal Highway Administration. Methods for maintaining pavement marking retroreflectivity. Disponível em:

$<$ https://safety.fhwa.dot.gov/roadway_dept/night_visib/fhwasa14017/ch2.cfm>. Acesso em: 04 mar. 2019.

FLINTSCH, Gerardo W. et al. The Little Book of Tire Pavement Friction. Newington: Pavement Surface Properties Consortium, 2012.

FRANÇA, A. Q. S. A Comodidade e a Segurança como Critérios Condicionantes da Geometria do Traçado. Tese de doutorado. Porto: Faculdade de Engenharia da Universidade de Porto, 1988. 367p.

GALLAWAY, B. M. et al. Pavement and geometric design criteria for minimizing hydroplaning. Texas: Federal Highway Administration, 1979.

HALL, J.W. et al. Guide for Pavement Friction, NCHRP Web-Only Document 108. National Cooperative Highway Research Program (NCHRP), Washington, D.C., 2009.

HASSAN, Yasser; EASA, Said M.; HALIM, A.o. Abd El. State-of-the-art of threedimensional highway geometric design. Canadian Journal of Civil Engineering. [s.I.], p. 500-511. 17 out. 1997.

HORNE, Walter B.; DREHER, Robert C. Phenomena of pneumatic tire hydroplaning. Washington, D.C: National Aeronautics and Space administration, 1963. 52 p.

IPEA - Instituto de Pesquisa Econômica Aplicada. Acidentes de trânsito nas rodovias federais brasileiras: caracterização, tendências e custos para a sociedade relatório de pesquisa Brasília: IPEA; 2015.

IPEA - INSTITUTO DE PESQUISA ECONÔMICA APLICADA; DENATRAN DEPARTAMENTO NACIONAL DE TRÂNSITO; ANTP - ASSOCIAÇÃO NACIONAL DE TRANSPORTES PÚBLICOS. Impactos sociais e econômicos dos acidentes de 
trânsito nas rodovias brasileiras - relatório executivo. Brasília: Ipea, Denatran e ANTP, 2006. Disponível em: <http://goo.gl/q5oVrr>.

KABBACH JUNIOR, F. I. Notas de aula da disciplina de pós-graduação PTR 5725: Tópicos Avançados de Projeto Geométrico de Vias Rurais e Urbanas. São Paulo: Escola Politécnica da Universidade de São Paulo - EPUSP, 2017.

Kennedy, C. K., Young, A. E., and Butler, I. C., "Measurement of Skidding Resistance and Surface Texture and the Use of Results in the United Kingdom," Surface Characteristics of Roadways: International Research and Technologies, ASTM STP 1031, W. E. Meyer and J. Reichert, Eds., American Society for Testing and Materials, Philadelphia, 1990, pp. 87-102.

KHAN, Ghazan; QIN, Xiao; NOYCE, David A.. Spatial Analysis of Weather Crash Patterns. Journal Of Transportation Engineering, [S.L.], v. 134, n. 5, p. 191-202, maio 2008. American Society of Civil Engineers (ASCE). http://dx.doi.org/10.1061/(asce)0733-947x(2008)134:5(191).

KUYPERS, Kim Paula Colette et al. A Case-Control Study Estimating Accident Risk for Alcohol, Medicines and Illegal Drugs. Plos One, [s.I.], v. 7, n. 8, p.43496-43496, 28 ago. 2012. Public Library of Science (plos).

Http://dx.doi.org/10.1371/journal.pone.0043496.

LARSEN, Johannes. Tratamento superficial na construção e conservação de rodovias. Rio de Janeiro: Abeda, 1985.

LARSON, Roger M. et al. Relationship between Skid Resistance Numbers Measured with Ribbed and Smooth Tire and Wet Accident Locations: FHWA/OH2008/11. Columbus, Ohio: Ohio Department of Transportation, 2008.

LI, Guohua; BRADY, Joanne E.; CHEN, Qixuan. Drug use and fatal motor vehicle crashes: A case-control study. Accident Analysis \& Prevention, [s.I.], v. 60, p.205-210, nov. 2013. Elsevier BV. http://dx.doi.org/10.1016/j.aap.2013.09.001.

MAYHEW, D. R.; SIMPSON, H. M. Alcohol, age, and risk of road accident involvement. Ottawa: Traffic Injury Research Foundation of Canada, 1983.

MELO, Rubem Penteado de. AVALIAÇÃO DA ESTABILIDADE LATERAL EM CONJUNTOS DE VEICULOS DE CARGA. 2004. $112 \mathrm{f}$. Tese (Doutorado) - Curso de Engenharia Mecânica, Puc-Pr, Curitiba, 2004.

MORADI, Ali; NAZARI, Seyed Saeed Hashemi; RAHMANI, Khaled. Sleepiness and the risk of road traffic accidents: A systematic review and meta-analysis of previous studies. Transportation Research Part F: Traffic Psychology and Behaviour, [s.I.], p.110, set. 2018. Elsevier BV. http://dx.doi.org/10.1016/j.trf.2018.09.013. 
MØRLAND, Jørg et al. Drugs related to motor vehicle crashes in northern European countries: A study of fatally injured drivers. Accident Analysis \& Prevention, [s.I.], v. 43, n. 6, p.1920-1926, nov. 2011. Elsevier BV.

http://dx.doi.org/10.1016/j.aap.2011.05.002.

MOUNCE, John M.; BARTOSKEWITZ, Richardt. Hydroplaning and Roadway Tort Liability. Transportation Research Record, Washington D.C, v. 1401, n. 1401, p.117124, dez. 1993.

MUELLER, T.H.. HEAVY VEHICLE STABILITY VERSUS CRASH RATES. Nova Zelândia: Ternz, 1999. Disponível em:

<http://www.ternz.co.nz/Publications/Heavy\%20Vehicle\%20Stability\%20Versus\%20Cra sh\%20Rates.pdf>

MUNDO Inovação - Engenharia Verde. Direção de Rodrigo Astiz; Nikolas Fonseca. Produção de Adriana Marques; João Daniel Tikhomiroff; Michel Tikhomiroff; Hugo Janeba. Roteiro: Thais Fonseca. Registro: Discovery Communication, Llc, 2018. Son., color.

NHTSA - National Highway Traffic Safety Administration. National Center for Statistics and Analysis. (2017, October). 2016 fatal motor vehicle crashes: Overview. (Traffic Safety Facts Research Note. Report No. DOT HS 812 Washington, DC: National Highway Traffic Safety Administration.456).

. REPORT TO CONGRESS: UPDATE ON THE STATUS OF SPLASH AND SPRAY SUPPRESSION TECHNOLOGY FOR LARGE TRUCKS. NHTSA, Washington, D.C. 1998.

. TRAFFIC SAFETY FACTS 2016. Washington, Dc: National Highway Traffic Safety Administration - U.S. Department of Transportation, 2018. 198 p.

NLT 329/91. Recuperación elástica por torsión de betunes asfálticos modificados: NLT 329. Madrid: Centro de Estudios y Experimentación de Obras Públicas, Espanha, 1991.

PAULA, Max Ernani Borges de; RÉGIO, Maurício. Investigação de acidentes de trânsito fatais. São Paulo: Companhia de Engenharia de Tráfego, 2008.

PECK, Raymond C. Et al. The relationship between blood alcohol concentration (BAC), age, and crash risk. Journal of Safety Research, [sold], v. 39, n. 3, p.311-319, jan. 2008. Elsevier BV. Http://dx.doi.org/10.1016/j.jsr.2008.02.030.

PLUG, Charlotte; XIA, Jianhong (Cecilia); CAULFIELD, Craig. Spatial and temporal visualisation techniques for crash analysis. Accident Analysis \& Prevention, [S.L.], v. 43, n. 6, p. 1937-1946, nov. 2011. Elsevier BV.

http://dx.doi.org/10.1016/j.aap.2011.05.007. 
PRATICÒ, F.G.; VAIANA, R. A study on the relationship between mean texture depth and mean profile depth of asphalt pavements. Construction And Building Materials, [S.L.], v. 101, p. 72-79, dez. 2015. Elsevier BV.

http://dx.doi.org/10.1016/j.conbuildmat.2015.10.021.

PULUGURTHA, Srinivas S.; KUSAM, Prasanna R; PATEL, Kuvleshay. Relationship between pavement macrotexture and crash incidences on North Carolina roads. North Carolina: North Carolina Department of Transportation, 2008.

Roe, P., Webster, D., and West, G. The Relation between the Surface Texture of Roads and Accidents. UK Transport and Road Research Laboratory, Research report 296, 1991.

Sabey, B. E.; Staughton, G. C. Interacting Roles of Road Environment, Vehicle and Road Users in Accidents. Paper presented at the 5th International Conference of the International Association for Accident and Traffic Medicine. Londres, 1975.

SALLES, Lucio Salles de et al. Avaliação retrorrefletiva de pintura de demarcação horizontal: peculiaridades e considerações sobre a norma e os requisitos mínimos nacionais. Transportes, [s.l.], v. 23, n. 3, p.5-17, 23 dez. 2015. Lepidus Tecnologia. http://dx.doi.org/10.14295/transportes.v23i3.886.

SALPICO, F. Estudo de Segurança Rodoviária, o Perigo Grave de Hidroplanagem nas Estradas Portuguesas - Formulação de Cálculo e Propostas para Resolução de Problemas. OSEC - Observatório de Segurança de Estradas e Cidades, 2009,

SANTOS, E. L. Análise histórica de medição de atrito das pistas do Aeroporto Santos Dumont - RJ. Trabalho de Graduação, Instituto Tecnológico de Aeronáutica ITA, Centro Técnico Aeroespacial, São José dos Campos, 2004, 124p.

SCARINGELLA TRÂNSITO. Investigação de Causas de Acidentes de Trânsito. Estudo de Amostra de Acidentes.

SILVA, A. M.; RODRIGUES FILHO, O. S. GROOVING: Aspectos Teóricos e Executivos da Aplicação em Pavimentos Aeroportuários. São Paulo: COPASP, 1981.

SMADI, Omar et al. Pavement Marking Retroreflectivity. Transportation Research Record: Journal of the Transportation Research Board, [s.I.], v. 2056, n. 1, p.17-24, jan. 2008. SAGE Publications. http://dx.doi.org/10.3141/2056-03.

Specht, L. P.; Rozek, T.; Hirsch, F.; Santos, R. T. Avaliação da macrotextura de pavimentos através do ensaio de mancha de areia. Teoria e Prática na Engenharia Civil, vol. 10, 2007, p. 30-38. 
SPITZHÜTTL, Florian; GOIZET, Fabrice; UNGER, Thomas; BIESSE, Frederic. The real impact of full hydroplaning on driving safety. Accident Analysis \& Prevention, [S.L.], v. 138, p. 105458, abr. 2020. Elsevier BV. http://dx.doi.org/10.1016/j.aap.2020.105458.

Treat, J.R., Tumbas, N.S., McDonald, S.T., Shinar, D., Hume, R.D., Mayer, R.E., Stanisfer, R.L., and Castellan, N.J. Tri-Level Study of the Causes of Traffic Accidents. Washington, DC: National Highway Traffi c Safety Administration. 1979.

TRIVEDI, Neha et al. Cell Phone Use While Driving: Prospective Association with Emerging Adult Use. Accident Analysis \& Prevention, [s.I.], v. 106, p.450-455, set. 2017. Elsevier BV. http://dx.doi.org/10.1016/j.aap.2017.04.013.

VIEIRA, Januário Leal de Moraes. Estudo de dirigibilidade de veículos longos combinados. 2010. 98 f. Dissertação (Mestrado) - Curso de Engenharia Mecânica, Escola de Engenharia de São Carlos, Universidade de São Paulo, São Carlos, 2010.

VINAYAKAMURTHY, Mounica. Effect of Pavement Condition on Accident Rate. 2017. 80 f. Dissertação (Mestrado) - Curso de Engenharia Civil, Arizona State University, Arizona, 2017.

WIERWILLE, W. W. et al. Identification and Evaluation of Driver Errors: Overview and Recommendations. Virginia: Virginia Tech Transportation Institute, 2002.

WHO - World Health Organization. Beber e Dirigir: Manual de Segurança de Trânsito para Profissionais de Trânsito e Saúde. Genebra: Global Road Safety Partnership; 2007.

. Global Status Report on Road Safety 2015. Geneva: World Health Organization, 2015.

. Global Status Report on Road Safety 2018. Geneva: World Health Organization, 2018.

ZEIN, Sany R.; NAVIN, Francis P. D. Improving Traffic Safety: A New Systems Approach. Transportation Research Record: Journal of the Transportation Research Board, [s.I.], v. 1830, n. 1, p.1-9, jan. 2003. SAGE Publications.

http://dx.doi.org/10.3141/1830-01. 